Historic, Archive Document

Do not assume content reflects current scientific knowledge, policies, or practices. 


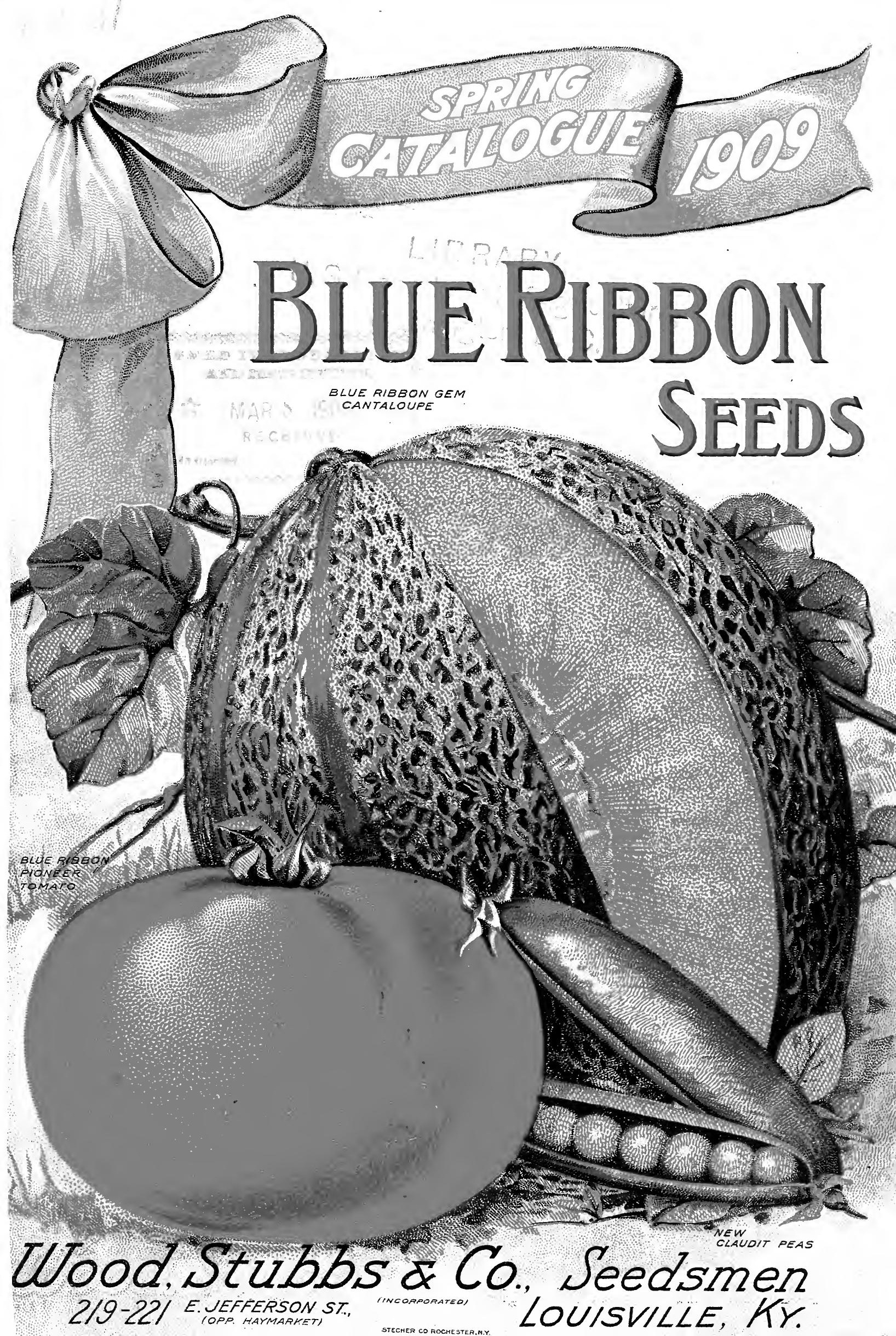




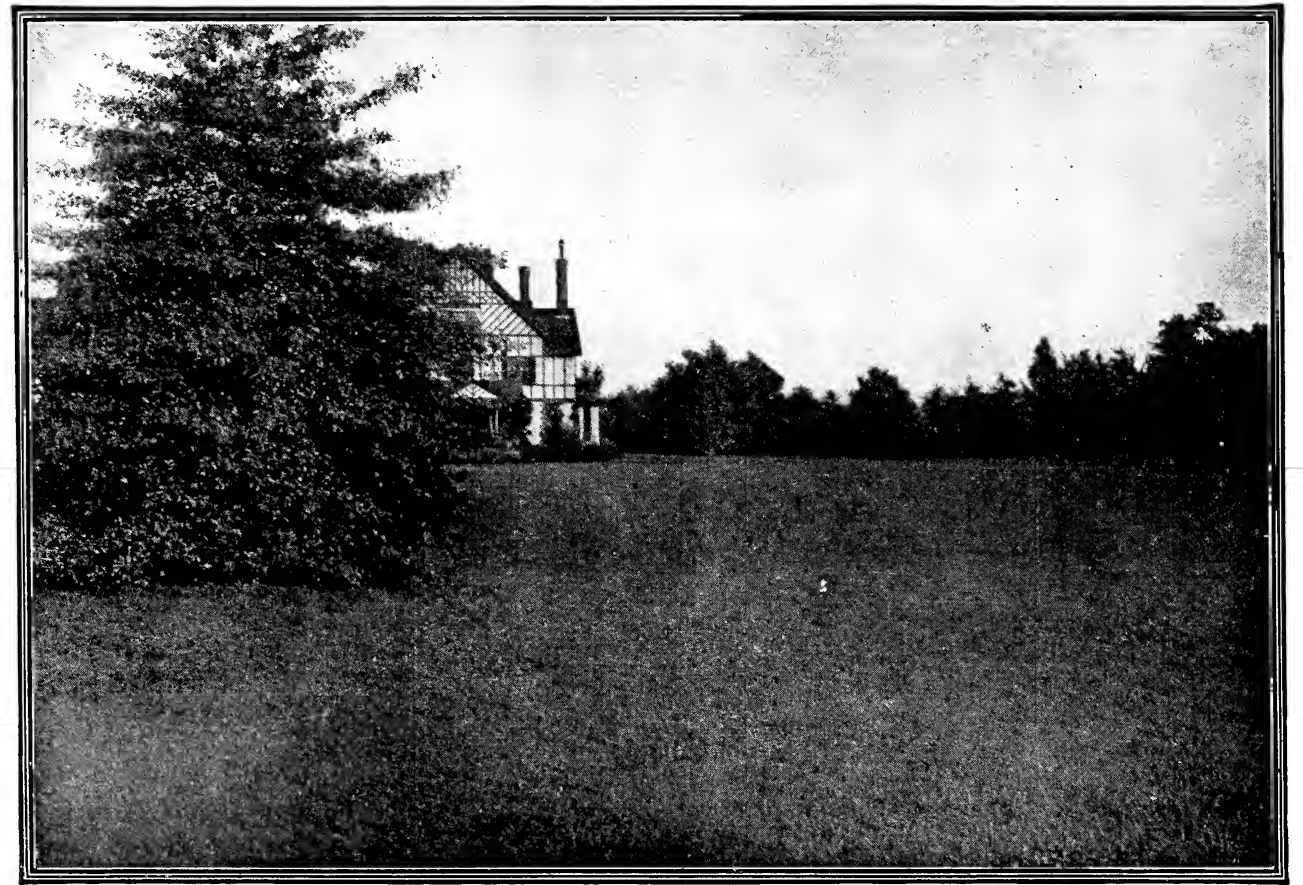

\section{WOOD, STUBBS \& CO'S CELEBRATED BLUE RIBBON LAWN GRASS SEEDS}

\section{FOR VARIOUS SOILS, CLIMATESAND LOCATIONS}

Used and Endorsed in all Sections of America as the FINEST QUALITY and MOST SATISFACTORY in Results for Small or Large Lawns, Tennis Courts, Golf Links, Parks, Cemeteries, etc., producing short, velvety green turf in 6 to 8 weeks which is of permanent lasting qualities.

BLUE RIBBON EVERGREEN. For northern and middle latitudes, this has been found the most satisfactory lawn grass seed that has ever been used. It is far better than the Kentucky Blue, producing a beautiful green sward in quicker time, is b.tter adapted to various soils and stands heat, drought of summer as well as severe cold, better than any of the various mixtures so commonly offered.

Whether for large or small plot, Blue Ribbon Evergreen Lawn Grass Seed will prove entirely satisfactory, and we believe it the best lawn grass seed offered anywhere. It weighs 20 pounds per bushel, where ordinary mixtures are only 14 pounds, therefore is more economical.

PRICES.-Postage paid-Pint 15c.; Quart 25c.; 4 quarts 90 c.

Without postage-Pint 10c.; Quart 20c.; 4 quarts 65c.; Peck (5 lbs.) $\$ 1.25$; Bushel $(20$ lbs.) $\$ 4.00$. 5 bus. and over at $\$ 3.50$ per bus.

SHADY GREEN LAWN GRASS. A special lawn grass seed for damp or shady situations, composed of the best growing, velvety green grasses, we have excellent reports from satisfied customers using this, and recommend it to be as satisfactory as anything which can be used for such locations.

PRICES.-Postage paid-Pint 20c.; Quart 35c.; 4 quarts, \$1.25.

Without postage-Pint 15c,; Quart 30c.; 4 quarts, $\$ 1.00$; Peck, $\$ 1.75$; Bushel, $\$ 6.00$.

DIXIE VELVET LAWN GRASS. For the far South and dry western states this is particularly recommended. It is a combination of short, thick-growing, grasses, with Bermuda grass, and affords a velvety green sod tine year around. Splendid for terraces facing southward, when other sorts burn out.

PRICES-Postage paid-Pint 20c.; Quart, 35c.; 4 quarts, \$1.25.

Without postage-Pint 15c.; Quart 30c.; 4 quarts, $\$ 1.00$; Peck, $\$ 1.75$; Bushel, $\$ 6.00$.

\section{PREPARATION, SOWING, ETC.}

FOR NEW LAWNS the ground should be deeply plowed or spaded, cultivating and smoothing to break up all clods, removing all trash and gotten as finely pulverized and smooth as possible. If not rich, use W. S. \& Co. Lawn and Garden Fertilizer, 5 lbs. to 300 square feet, or 500 to 1,000 lbs. per acre. Sow seed in February or March or April, 1 quart to 250 square feet $(12 \times 12)$ or 3 to 4 bushels per acre, covering with a light rake or harrow, and afterwards roll or board the ground. For prices see page 65.

For renovating old lawns, harrow or rake over the old grass, especially the bare spots, apply one-third to one-half as much seed and a good application of fertilizer, rolling afterwards.

Pull out or cut with a knife weeds or coarse grasses which spring up from all newly cultivated soils. Cut regularly with a lawn mower during the season, but not closer than two inches during the summer. In very dry weather a thorough watering once a week in the evening will be beneficial, but too much will drown out the grass, and it will require reseeding next year. 


\section{To Our Friends and Customers:}

This is our Eleventh Annual Catalogue. Our business has grown twenty times larger than that of our first year's business in Louisville. This indicates that BLUE RIBBON SEEDS are of superior merit. The fact that most of our customers of the first year are still with us to-day, and that tens of thousands of pleased customers have been added who order BLUE RIBBON SEEDS year after year is, however, the strongest endorsement. We extend thanks for many favors of the past, and ask a continuance.

BLUE RIBBON SEEDS for the Garden, Farm, Lawn, and Greenhouse are the very highest quality stocks, and selected with greatest care and supplied at extremely reasonable prices. We ask the pleasure of a visit to our new buildings, Nos. 219-221 East Jefferson Street, which are most thoroughly equipped with modern and up-todate arrangements and machinery for handling and despatch of the seed business in all of its branches.

Owing to excessive drought, which prevailed in nearly all sections of the country, stocks are again short this year, therefore we request your orders at the very earliest

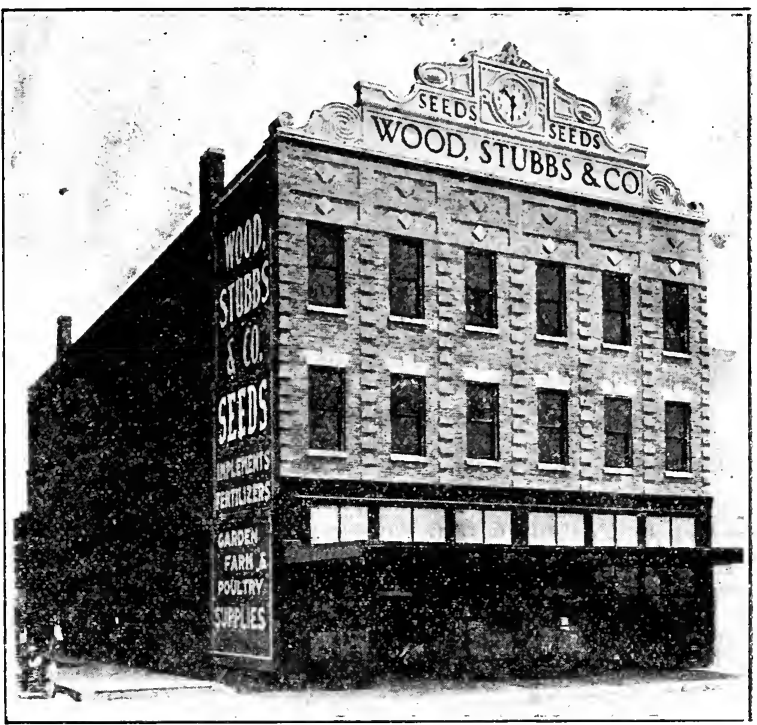
possible date.

Prices have been made very reasonable, and are those ruling at the time this catalogue was issued. All prices are subject to some modifications, however, and those of Clover, Grass Seeds, Potatoes, Onion Sets, and other Field Seeds, are constantly subject to change, and in purchasing these, customers are asked to write for current prices. On considerable quantities of Vegetable Seeds we shall be very glad to make such concessions as are reasonable.

Our catalogue will be found very helpful in suggestions, cultural information, etc. The list of Seeds embraces the best sorts. We would suggest that you look over it, order from it now, and keep it for later use. When special information is desired kindly write us.

With well wishes for a prosperous year, we are,

Louisville, Ky., January 1, 1909.

Yours very truly,

WOOD, STUBBS \& Co.

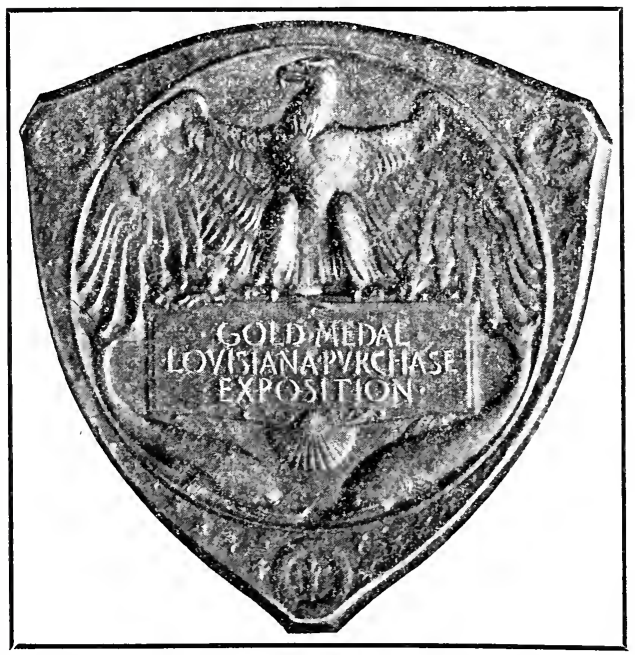

\section{A BEAUTIFUL CALENDAR FREE.}

With many of our customers this has become the standard reminder for practical information on Garden and Farm work. In addition to the days of the month printed on a good-sized pad in clear type, together with phases of the moon, the valuable feature is that following each calendar page is a sheet showing seeds to be sown and work in the garden and on the farm for each month, with many useful hints of practical value. The design is a beautiful half-tone.

This valuable Calendar will be sent free with every order from the catalogue for Vegetable and Flower Seeds to the amount of Fifty Cents and over, provided the order is sent early and the Calendar requested. Stock of Calendars is limited and will be supplied as long as they last.

\section{About Warranting Seeds}

Wood, Stubbs \& Co. give no warranty, expressed or implied, regarding description, quality, productiveness, or any other matter garding description, quality, productiveness, or any other in any way responsible for the crop. If the purchaser does not accept the goods on these terms, they are to be returned at once, and any money that has been paid for them will be refunded. Every order received for articles in this catalogue will be executed on these conditions only. 


\section{GARDEN AND FARM CALENDAR}

Information given here applies to Louisville and climate and lociations similar; for other sections allowance must be made according as they are early or later. Moon phases based on central time.

January. F. M. 6th L. Q.14th N. M. 21st 1st 0. 28th Send order for seeds now; while stocks are full, so as to have them on hand as the sowing seasons come around. We can ship later if desired. Prepare hot beds, start in them early Cabbage, Lettuce, Radish, Beet, Cauliflower, Onion, and Pansy, and some other flower seeds which require transplanting. (See list under slower Weeds.)

Outdoors. - As the weather will permit, prepare the ground for later crops. Top-dress Asparagus beds with manure and salt or kainit; mulch Strawberries with straw; prune trees and small bush fruits, haul leaves and compost them with manure. On late wheat or grass fields.

Febriary. F. M. 5th L. Q. 13th N. M. 20th 1s1 0.26th If not already sown, start in hot beds or cold frames early Cabbage, Lettuce, Radish, Beet, Cauliflower, early Cabbage, Lettuce, Radish, Beet, Cauliflower, the month Egg Plants and Peppers. These require warmer beds than the other seeds mentioned.

Outdoors.- The last of the month, if favorable weather, sow early Peas, Spring Kale, Beets, Spinach, Carrots, Celery, Radish, and Parsley. Set Onion Sets, Horse Radish, Asparagus, and Rhubarb. Plant trees and bush fruits. Sow Blue Ribbon Evergreen Lawn Grass. Prepare and sow Tobacco beds. Towards the Grass. Prepare and sow Tobacco beds. Towards the for early Hay. Clover and Grass Seeds can be sown this month, also Rape for grazing and soiling.

March. F. M. 6th L. 0.14th N. M. 21st 1st 0. 28th. Seeds for early plants can now be started in cold frames or window boxes instead of hot beds. Tender seeds such as Egg Plants, Peppers, and tender flower seeds require a little more heat.

Outdoors.- The sooner most hardy seeds are in, the better. We name them in the order in which they should be sown. Garden Peas in varieties for succession, Cauliflower, Early Cabbage, Onion, Celery, Spinach, Leek, Parsley, Lettuce, Radish, Beet, Asparagus, Carrot, Parsnip, and Salsify. Plant Irish Potatoes, Asparagus, Rhubarb Roots, and Onion Sets if not already done. Set out Cauliflower, Cabbage, Onion, and Lettuce Plants from hot beds after these have hardened by leaving the glass open at nights. Sow Herbs in a warm border. Sow the hardy kinds of flower seeds; also this is the proper month for sowing Lawn Grass.

For the Farm.-Winter and Spring Oats, Canada Field Peas with Oats, Clover Seeds, Grass Seeds of all sorts, Tobacco Seeds should all be sown quickly.

April. F. M. 5th L. 0. 13th N. M. 19th 1st Q. 27th Seeds that have not previously been put in as recommended in the preceding months can still be sown, except that instead of using hot beds for hardy sorts of plants, they can now be sown in beds in the open ground. Summer Cabbage, Lettuce and Tomatoes should be sown for succession to follow the earliest sorts; likewise Beets, Radish, Peas. The first planting of Artichokes, Herbs, Corn, Snap Beans, and Okra can be made early this month, and Cucumber, Squash, Cantaloupe, and Watermelon the latter part, May. Wabbager is favorable; otherwise defer pint May. Cabbage, Lettuce, Cauliflower, Onion, and Beet plants, which have been started earlier, should be transplanted; also Strawberry plants set, as this is
the best month. Sweet Potatoes can be put in hot beds previously used for Cabbage. Lawn Grass can still be sown, and all Clover and Grass seeds. Sow Mangel Wurtzel and Stock Beets. Plant Corn for early crop.

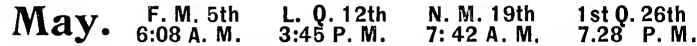
This is the month for sowing most tender seeds out of doors and all other seeds which were not sown previously can still be put in out of doors. If Cucumber, Cantaloupe, Watermelon, and Squash have not been planted, put them in early as possible. Snap Beans for succession, Lima and Pole Beans, first planting should be made early. Cabbage seed for planting should be made early. Cabbage seed for also Black-Eye Peas for winter use. Set out plants for Tomato, Pepper, Sweet Potatoes, and Egg Plant. Continue sowing flower seeds and plant bulbs.

For the Farm. Sugar Beets and Mangel Wurtzel for winter feeding and stock can still be sown; also all Sorghums, Millet, Fodder Plants, Cow Peas; Soja, Navy, and Velvet Beans can be planted. Set out Tobacco plants latter part of the month. Keep down bacco plants latter part of the month. Keep down
weeds and destroy the first crop of insects effectually.

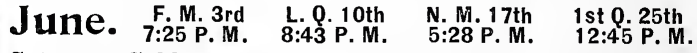

Set out Cabbage, Tomato, Egg Plant, Pepper, and Sweet Potato plants. Sow Tomato for late crop; likewise late Cabbage and Cauliflower for winter usePlant Okra, Watermelon, Cantaloupe, Cucumber, Squash, and Pumpkin for late use, and Snap and Pole Beans and Sweet Corn for succession.

For the Farm.-Sow the Millets, Cow Peas, Sorghum, Soja Beans, Navy Beans, and plant Late Corn. the seed should be soaked twenty-four hours before sowing.

$\begin{array}{cccc}\text { July. } \quad \text { F.M. 3rd } & \text { L. O. 10th } & \text { N. M. 17th } & \text { 1st } 0.25 \text { th } \\ 6: 17 A . M . & 0: 58 \text { A. M. } & 4: 45 \text { A. M. } & 5: 45 \text { A.M. }\end{array}$ Plant Snap Beans for succession and Sugar Corn for late roasting ears. Set out Late Cabbage plants for winter use, likewise Celery plants. This is the best month to sow Ruta-baga, and they do best in rows. Plant Cucumbers for pickling and table, and Late Potatoes for winter use.

For the rarm.-Sow German or Hungarian Millet for hay or fodder; likewise Corn in drills for ensilage or fodder. Buckwheat can be sown for bees as an improver of the soil, and for grain. Plant Navy Beans, Black, Black-Eye, and Whippoorwill Peas.

August. F.M. 1 st. L.0. 8th N.M. 15th 1st 0. 23rd F.M. 30th Continue planting Snap Beans for the table and pickles. If any Cabbage plants remain unplanted, put out at once; likewise Celery plants. Trim off the tops of Celery before planting, if the plants are large. Sow Lettuce seed for fall use, likewise $\mathrm{En}-$ dive. Sow Spinach and Kale. Finish sowing Rutabaga seed. All kinds of Turnip seeds can be sown during this month. Crimson Clover is one of the best crops grown, and should be. sown on every vacant place where crops have been cleared off; if it is not required for feed, it will improve the soil equal to manure when turned under.

For the Farm.-Buckwheat, Rye, and Barley should be sown for fall and winte
afterwards will make a crop of grain.

September L. 0.6th N. M. 14th 1st 0.22nd F. M. 29th Our Fall Catalogue, issued about August 20th, gives full information about all seeds and bulbs for fall sowing, mailed free upon request. Sow Lettuce, put out Onion Sets, sow Winter Radishes, Spinach, Turnips, Mustard, Corn Salad, and Kale. Dutch Bulbs, nyacinths, Tulips, etc., can be planted toward the end of the month. Sow W., S. \& Co.'s Evergreen end of the month. Sow W., S. \& Co.'s Evergreen and beauty of a home than a nicely kept, green lawn. For the Farm.-Sow Crimson Clover this month. Winter Oats will do well sown this month, as they will get well rooted before winter. Sow all kinds of Grass and Clover seeds and Winter and Sand Vetch. Continue to grow Barley and Rye, as they are useful Continue to grow Barley and Rye, as the
for winter grazing as well as for grain.

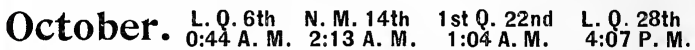
Put out Onion Sets. Sow Turnips for salad, Kale, Mustard, Spinach, and Lettuce. Sow Lawn Grass seed. Fall seeding does better than spring seeding. cold frames for spring plants.

For the Farm.-All kinds of Grass and Clover seeds can be sown this month, but the earlier Clover seed is put in the better. Sow Wheat, Oats, Rye. Barley, Vetches.

November L. 0. 4th N. M.12th 1st 0. 20th F. M. 27th Sow Lettuce and early varieties of Cabbage in cold frames, leaving the glass off at the time to harden them. Set out Cabbage and Lettuce plants. Lawn Grass seed can yet be sown, but the earlier it is put in, the better. All kinds of Flowering Bulbs set out $n$ the fall can be put in this month.

For the Farm.-Wheat, Rye, Barley Timothy, and Red Top seed can yet be sown, but the earlier they are put in, the better.

December. L. 0.4th N. M. 12th 1st 0.19th F. M. 26th The only seeding that can be done this month is in the hot bed or greenhouse. Cabbage and Lettuce can be sown towards the end of the month, and Beets, Radish, and Lettuce can be forced for winter use. The winter growing of Lettuce in hot beds usually proves very profitable and satisfactory. 


\section{BLUE RIBBON VEGETABLE SEEDS}

IN BULK AND PACKETS.

With Cultural Instructions and General Information for all Varieties.

SEEDS BY MAIL will travel safely, and the postage rates are as follows:

PACKETS-OUNCES AND $1 / 4$ LBS. are Mailed Free at prices charged.

ON BULK SEEDS, add for postage as follows: 1 lb. $8 \mathrm{c}, 1$ pt. $8 \mathrm{c}, 1$ qt. $15 \mathrm{c}$ extra.

SEEDS BY EXPRESS.-The Special Express Rate on seeds is 20 per cent less than the usual merchandise rate, and this is far the best way to order goods sent, provided the order is of moderate weight, and the distance is not too great. If desired, we will quote you special rate to any point if the quantity of goods be given us, and where large quantities of seeds are wanted, will quote prices delivered.

SEEDS BY FREIGHT.-Freight rates from Louisville to almost any point in the country are very low, due to the fact that we have a great many railroads centered here. Special rates to any point, or delivered prices quoted on request.

We would especially advise seeds being sent by freight or express in preference to mail, as they will travel more safely, and if Garden Seeds are included with Field Seeds, Implements, or Fertilizers, the price of delivery to your station will be comparatively little.

\section{ARTICHOKE}

There are two distinct kinds as offered below. The Large Globe produces undeveloped flower heads which are cooked like Asparagus, being very delicious, and is fast becoming an important crop for the South, to which it is particularly suitable. The Jerusalem produces tubers which are excellent for stock and quite often used for table, being boiled like potatoes. Also excellent for mixed pickles.

LARGE GLOBE. Half an ounce produces 300 plants sufficient for a good-sized garden. Six ounces per acre. Pkt. $5 \mathrm{c}$, oz. $25 \mathrm{c}, 1 \mathrm{lb} . \$ 3.00$.

Culture.-Seed sown in hot beds is transplanted in May. If in the open ground, sow in April in rowg ffteen inches apart and one inch deep, thinning out to four inches, and transplanting the following spring to rows three feet apart and two feet between the plants. Should be given slight protection in winter with to rows three feet

JERUSALEM (Tubers). One quart cut plants 60 to $75 \mathrm{feet,} 6 \mathrm{bu}$. per acre. Plant and cultivate like potatoes. Per qt. 20c, by mail $35 \mathrm{c}, \mathrm{pk}$. $65 \mathrm{c}$, bu. $\$ 2.00$. Special price in large quantities.

\section{ASPARAGUS}

One ounce sows 35 feet, producing about 800 plants. Fifteen pounds sow one acre. One pound produces plants to set one acre. Seed sown in March or April. Set roots in February or March, or in November.

One hundred roots plant a bed $15 \times 50$ feet, sufficient for medium garden. An acre requires 4,000 to 7,000 .

Culture.-Asparagus beds are planted with good roots one or two years old. The size of asparagus depends more on high fertilization than on the variety. Plow or dig out trenches eighteen inches wide and ix to ten inches deep, making the trenches four or eight feet apart. In the bottom of the furrow scatter Acme Brand Potato Fertilizer and an application of well rotted manure, which dig lightly in and mix with the soil, and then set the plants fifteen inches apart in the rows. Spread out the roots carefully and cover with soil and manure, care being used not to cover the crowns more than two or three inches at first, as the first shoots from the young roots are not strong enough to force through a deep mass of earth. To make white asparagus, the beds must be freshly and lightly earthed up each spring just before the growing season commences. To raise asparagus roots from seed, sow the seed thinly, one inch deep in rows fifteen inches apart. Keep clean of weeds and thin out the plants to four inches apart. When one or two years old set out in permanent beds, as given above. Insect Remedy.-For the asparagus beetle use slug Shot or freshly slacked lime dusted on before the dew has disappeared.

COLUMBIAN MAMMOTH WHITE. Clear white shoots, not tinged

with pink or purple, tender and excellent quality
PALMETTO. A favorite sort in Southern section, being a little earlier than other sorts. Thick, succulent shoots somewhat more pointed at the tips than Conover's Colossal--

GIANT ARGENTUIL. The best French sort, highly prized by growers. Leaflets closely contracted at tips, which are blunt --.-.- 5

CONOVER'S COLOSSAL. Old standard sort.-...- 5 $\$ 6.00$. Special prices on large quantities on any of the above sorts. 


\section{B E A N S}

\section{Dwarf}

Called String Beans, Bush Beans, and Snap Beans.

For Beans in bulk by mail, add $8 c$ to pint and ${ }_{15} \mathrm{c}$ to quart prices. Pkts. postpaid.

One pint sows 80 feet. An acre requires one to one and a half bushels. One half pint planted every three weeks is sufficient for a medium garden. Plant in succession from April till September. They are ready for the table in from forty to sixty days after planting.

Culture.-Beans do not require heavy manuring; in fact if the soil is fairly good it is better to use a good fertilizer, such as Acme Brand B. B. P. The fertilizer should be well mixed in the furrow with the soil before the beans are planted. For field culture plant in rows two and a half feet apart and about three Inches between the beans covering the seed to a depth of about three inches. If to be cultivated by hand in small gardens, the rows may be eighteen inches apart. Up to the time of blooming cultivate often, but never while the vines are wet, as the pods and leaves would become discolored.

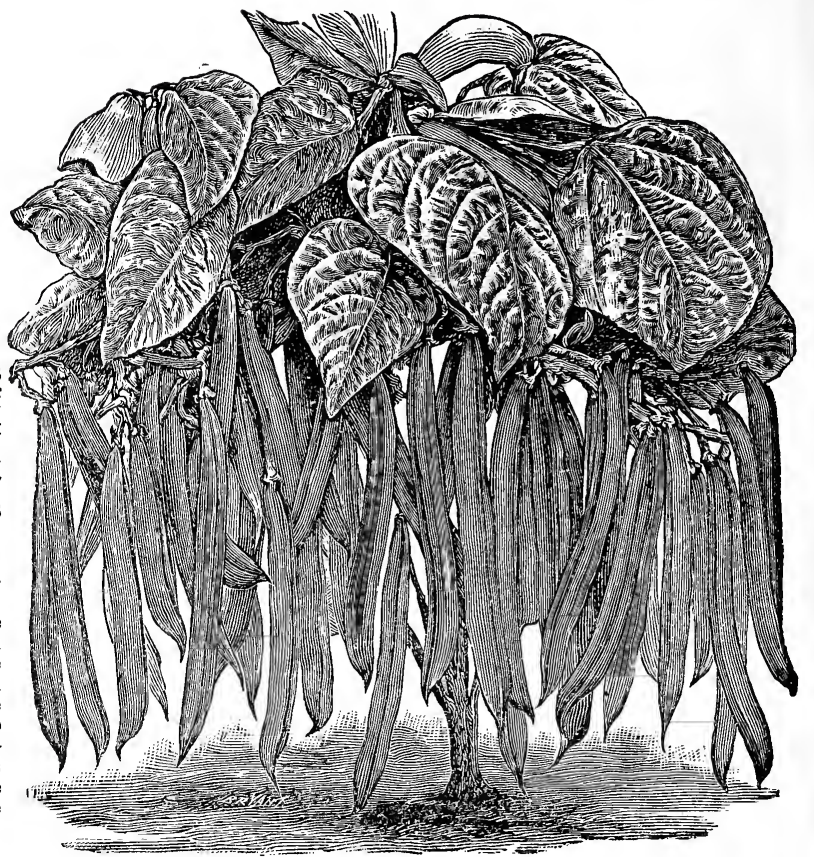

Taylor's Green Pod Beans

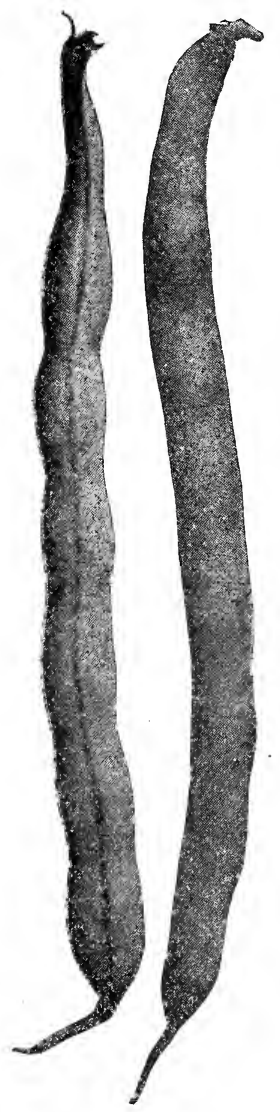

Full Measure Beans

\section{GREEN PODDED VARIETIES}

TAYLOR'S GREEN POD. Market gardeners have found this an extremely profitable sort, coming in, as it does, a week or ten days ahead of Valentine or other stringless sorts, and while not producing quite as large pods as the others, the fact that it is absolutely stringless and so early, makes it very profitable, and will give satisfaction for private garden. The pods are about four inches in length, straight, bright green, and of excellent quality. Seed is yellowish, oval in size, and about the size of Golden Wax. Pkt. 5c, pt. 10c, qt. 20 c, 4 qts. 75 c, bu. $\$ 4.75$.

FULL MEASURE. This new variety is a cross between Improved Refugee and Yosemite Mammoth Wax. It inherits the productiveness of the Refugee, makes long, straight, handsome, green pods, and is entirely stringless. The plant is a very strong, rank grower, and produces handsome green pods in greatest abundance. Closely follows in earliness New Stringless Green Pod. Splendid for market or family gardens. Pkt. 5c, pt. 15 c, qt. 25 c, 4 qts. 85 c, bu. $\$ 5.00$.

GIANT STRINGLESS GREEN POD. The pods of this variety resemble the well-known early Valentine, and they are fully one-third larger, and the crop is borne almost as early. The plants are of robust growth, pods five to six inches in length, of light green color, slightly curved, and very meaty and stringless. A most excellent sort for either market, garden, or family use. Pkt. 5 c, pt. 10 c, qt. 20 c, 4 qts. 75 c, bu. $\$ 4.50$.

NEW STRINGLESS GREEN POD. Of robust growth, producing beautiful, long, straight, round-podded snaps, which are absolutely stringless. By reason of its unusual hardiness, extreme earliness, and wonderful productiveness, and with handsome pods of the finest quality, this is one of the most popular of the green-podded snaps, either for market or family use. Pkt. 5c, pt. 10 c, qt. 20 c, 4 qts. 75 c, bu. $\$ 4.50$.

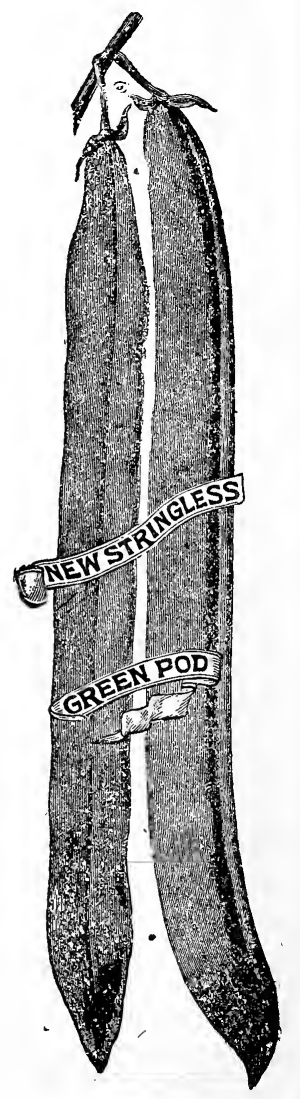




\section{BEANS-Green Podded Sorts-Continued}

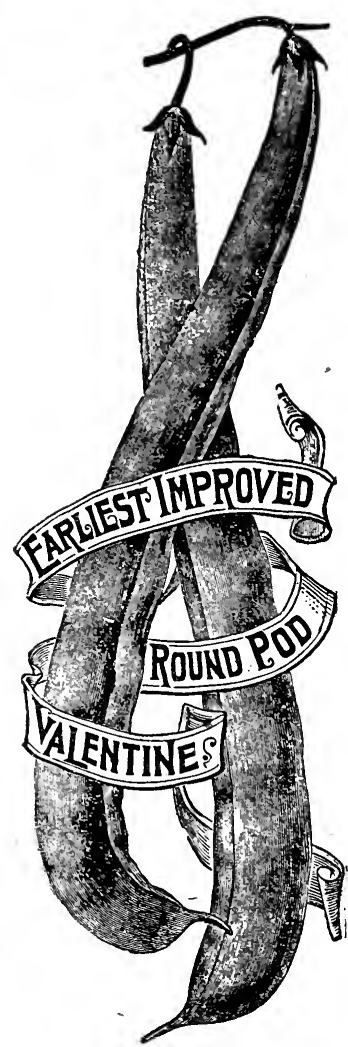

IMPROVED EARLIEST RED VALENTINE.

Pkt. Pt. Qt. 4 qts. Bu.

"The Blue Ribbon Stock." This is far superior to ordinary strains, being true roundpodded, earlier and more prolific than cheap Western stocks. It is stringless, with round, meaty pods 4 to 5 inches in length, slightly curved, and of unexcelled quality. For earliness and superior yield our Improved Blue Ribbon stock is far the most superior strain offered 5

$10 \quad 20 \quad 60 \$ 400$

Early Yellow Six Weeks. Extra early, greenpodded sort, with long, flat pods. Valuable only for very earliest planting

Extra Early Refugee. Pods straight and stringless; borne in clusters and easily picked. Good for very early or late use for table, shipping, and splendid for pickling --.-----

Improved Refugee, or 1000 to 1 . A fine late snap; enormously productive. Pods straight, medium sized, stringless; flesh thick and tender_ $5 \quad \begin{array}{lllll}10 & 15 & 50 & 3 & 75\end{array}$

DWARF HORTICULTURAL. (Also called locally Italian Beans.) Large green pods, splashed with carmine. Excellent either as snaps in the green state, or shelled green or dry. In this neighborhood is one of the very best selling beans on the market._-_._-_.-- 5

$\begin{array}{lllll}10 & 15 & 50 & 3 & 75\end{array}$

5

$10 \quad 15 \quad 50 \quad 375$

VARIETIES FOR SHELLED BEANS ONLY.

Royal Dwarf White Kidney. Excellent green or dry for soup, boiling, or as baked beans_--- $\begin{array}{rllll}5 & 10 & 15 & 50 & 3\end{array} 50$

French Red Kidney. Similar to above; beans are maroon color

Dwarf White Navy. More prolific than the common white bean. Finest table quality_-_- $5 \quad 10 \quad 15 \quad \begin{array}{lllll}50 & 30\end{array}$ For other Field Beans, see under FARM SEEDS.

\section{Wax Podded Beans}

Very tender and excellent for family use. Command best prices on the Northern markets. Excellent for pickling.

ROUND-POD KIDNEY WAX. A great improvement over Wardwell's Kidney Wax, as it has a true round pod of fully as good quality as that flat-podded sort. Then, as it is much more hardy and produces much better crops, we recommend it as one of the finest sorts for the Southern grower, home market, or for family use. Pkt. 5c, pt. 15 c, qt. 25 c, 4 qts. 85 c, bu. $\$ 6.00$.

WARDWELL'S KIDNEY WAX. The most popular of early wax sorts. Pods long, tender, and finest quality; liable to rust, however. This sort is the one so largely planted by Southern truckers for shipping, and on account of its fine appearance and excellent quality is very popular for market and home use. Pkt. 5c, pt. 15c, qt. 25c, 4 qts. 75 c, bu. $\$ 5.00$.

KEENEY'S RUSTLESS GOLDEN WAX. Probably the largest yielding of all the wax sorts, producing great numbers of pods. Almost absolutely free from rust, a vigorous grower, throwing out tendrils somewhat resembling a pole bean. Pods long

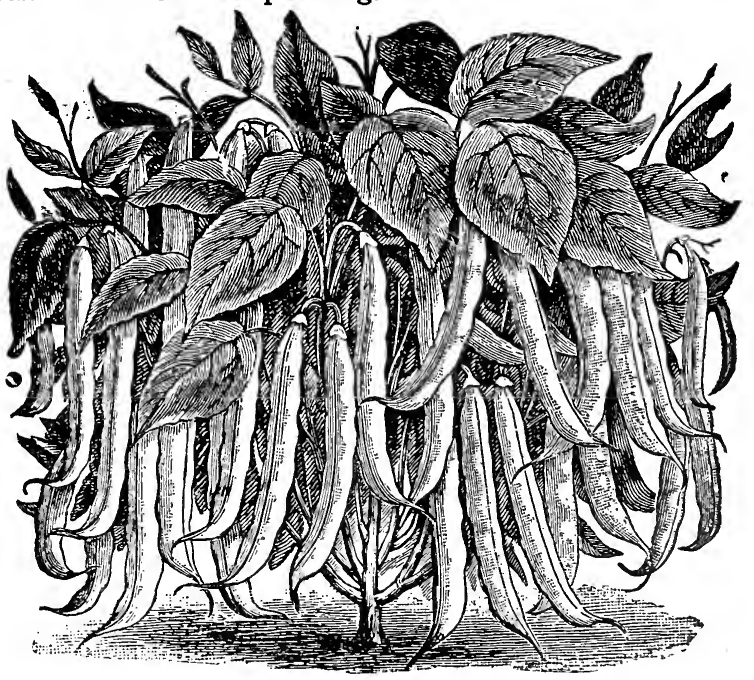

Wardwell's Kidney Wax Beans and straight, flat, of bright yellow color, stringless, and of good quality. We strongly recommend this for general cultivation for market uses. Pkt. $5 \mathrm{c}$, pt. $15 \mathrm{c}$, qt. $25 \mathrm{c}, 4$ qts. $75 \mathrm{c}$, bu. $\$ 5.00$. 


\section{BEANS-Wax Podded Sorts-Continued}

Dwarf German, or Black Wax. Pods about four inches long, round, of a beautiful waxy color, very brittle; a favorite variety for home use or market and pickling. Pkt. 5c, pt. 15c, qt. 25c, 4 qts. 75c, bu. $\$ 5.00$.

Davis' White Wax. Largely grown for shipping. First early, nearly always rust proof, extraordinarily productive, full and solid, of a beautiful yellow appearance; not entirely stringless. Pkt. $5 \mathrm{c}, \mathrm{pt}$. 15 c, qt. 25 c, 4 qts. 75 c, bu. $\$ 5.00$.

Dwarf Golden Wax. Very early, stringless, of flat shape, and rich golden yellow color. Vines not so vigorous as Rustless Golden Wax, but does not produce tendrils. Pkt. 5c, pt. 15c, qt. 25c, 4 qts. $75 \mathrm{c}$, bu. $\$ 5.00$.

\section{Pole or Corn Field Beans}

Culture.-Pole Beans are more sensitive to cold and wet than the Snap Beans, and should not be planted before May. Set poles eight feet long firmly in the ground, four feet apart each way, and put five or six beans, eye downward, in each hill.

Packets of all Beans 5c each, postpaid. Beans in bulk by mail, add $8 \mathrm{c}$ per pint, $15 \mathrm{c}$ per quart.

\section{GOLDEN CARMINE PODDED HORTICULTURAL.}

A week to ten days earlier than Horticultural Pole. In comparison the pods are equally as large, stringless, bright golden color when very young. As they approach full size, are mottled and streaked with an unusually bright carmine color on the bright ground, which gives the pods (when ready for market) a strikingly beautiful and attractive appearance. Excelling in earliness, quality, handsome appearance and productiveness, will make it the most desirable strain of this well-known and popular bean. Pkt. 5c, pt. 15c, qt. 30 c, 4 qts. $\$ 1.00$.

IMPROVED KY. WONDER, or OLD HOMESTEAD. The most popular of all pole beans, especially in this section. Vines are vigorous in growth, the pods are immense, often obtaining a length of nine or ten inches, and borne in large clusters. Bright green, very solid, meaty, tender, and stringless when young; assuming a saddleback shape with age, being broader in width than depth, and becoming somewhat irregular and spongy as the beans ripen. Dried beans are long, oval, and dun color. Very early and one of the best for general purposes in our list. Pkt. $5 \mathrm{c}$, pt. $15 \mathrm{c}$, qt. 30 c, 4 qts. $\$ 1.00$.

Cut Short, or Corn Field. (Red Speckled.) An old popular variety, and one of the best for planting among corn. Vines are not quite so heavy as Kentucky Wonder, and will produce a good crop without the use of poles. The pods are short, tender, bearing the beans very close together in the pods. Pkt. 5c, pt. 10c, qt. 25 c, 4 qts. 80 c.

Lazy Wife's Pole. Pods produced in large clusters very abundantly, and are four to five inches in length. Dark green, rather flat, broad, thick, fleshy, and entirely stringless. Beans pure white and excellent for shelling. Pkt. 5c, pt. $15 \mathrm{c}$, qt. $30 \mathrm{c}, 4$ qts. $\$ 1.00$.

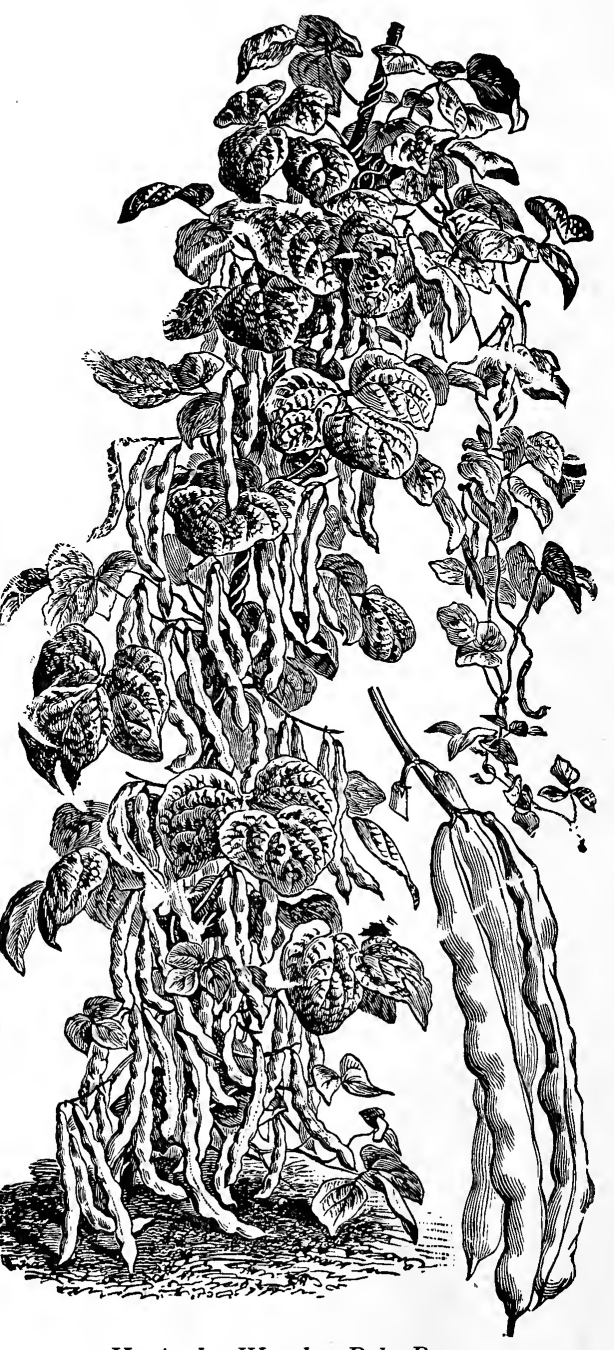

Kentucky Wonder Pole Beans

Perry County, Ky., Jan. 6, 1908. I have been a customer of yours for two or three years, and find that your seeds are what they are recommended to be.

Vanderburg County, Ind., July 29, 1908.

Please ship us 200 pounds No. 1 Blue Grass. We have had Blue Grass from you heretofore gave good satisfaction. 


\section{LIMA BEANS}

\section{$3 \times$}

\section{Dwarf or Bush Varieties}

One pint of small-seeded sorts plants from 100 to 125 feet, and is sufficient for an ordinary garden, or 1 quart of the large-seeded sorts. For succession, make two plantings four weeks apart. Mature in from 75 to 90 days from planting.

Culture.-Plant in May in rows like Dwarf Bush Beans; drop two beans every twelve or fifteen inches apart. Cultivate like Snap Beans.

Packets of Beans 5c èach, postpaid. Postage on Beans in Bulk, pint 8c, quart $15 \mathrm{c}$.

NEW WONDER BUSH LIMA. The beans are about as large as Burpee's Bush Limas, but are much more prolific and superior in yield. The pods are long, contain three to four beans each, and are borne in profusion until frost. While not quite so early as Wood's Prolific Bush Lima Beans, the fact that the beans are larger in size will make it popular where large Lima Beans are desired. Pkt. 5c, pt. 20c, qt. $40 \mathrm{c}, 4$ qts. $\$ 1.25$.

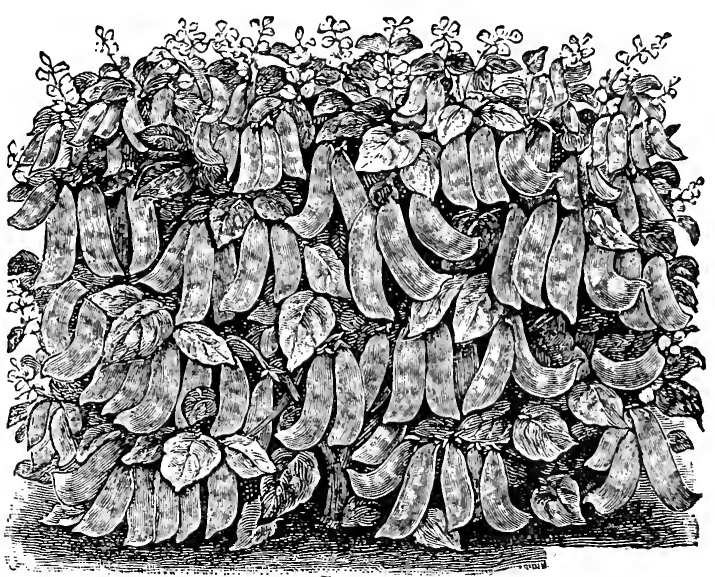

Wood's Prolific Bush Lima Beans

WOOD'S PROLIFIC BUSH LIMA. A very much improved type of Henderson's Bush Lima, having much more foliage and producing a larger crop of beans at least one half again larger in size. It is as early as any, very productive, and the most satisfactory of all small-seeded bush sorts. Pkt. 5c, pt. 15 c, qt. 30 c, 4 qts. $\$ 1.10$.

Henderson's Bush Lima. This standard variety has enjoyed great popularity. They are two weeks earlier than the Pole Limas, and wonderfully productive, averaging about sixty pods to the bush, bearing three to four small beans. Of hardy growth, compact, very prolific, and continue in bearing till frost. Pkt. $5 \mathrm{c}$, pt. $15 \mathrm{c}$, qt. $30 \mathrm{c}, 4$ qts. $\$ 1.00$.

Burpee's Bush Lima. The bush form of the well-known Large Lima, and although not so early or productive as the preceding variety, the large size of the beans make it desirable. $\mathrm{Pkt}$. $5 \mathrm{c}$, pt. 15 c, qt. 30 c, 4 qts. $\$ 1.15$.

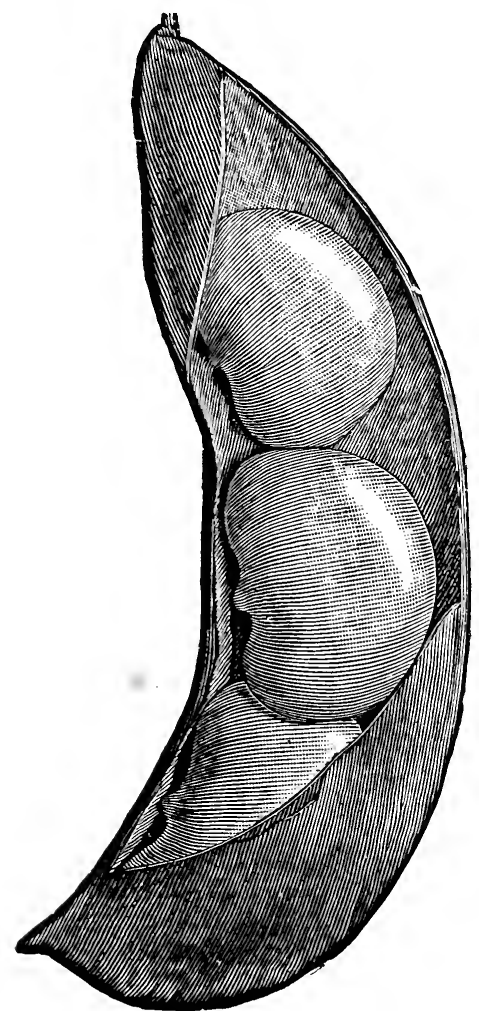

King of the Garden Lima Beans

\section{Lima Beans}

\section{Pole Varieties}

Large-seeded sorts require one quart to 100 poles; $3 / 4$ bu. to acre. Small Lima require about one-third the quantity.

Culture.-Set poles four feet apart, plant about four or five beans to the hill after the ground is warm. Use the hoe for cultivating.

FORD'S MAMMOTH PODDED. This is Pkt. Pt. Qt. 4 qts. the result of twenty years' selection by a successful market gardener, and far surpasses in size and productiveness any other variety. Pods usually contain five to seven beans of most excellent quality. Vines grow vigorous, setting the beans early, and continue bearing until frost -.--

Jersey Extra Early. Matures four or five days earlier than ordinary Large Limas, producing large beans and well-filled pods

\author{
5
}

$20 \quad 35 \quad \$ 125$

ing of the Garden. A favorite sort on account of its large size and profusive bearing qualities. Usually produces four or five beans to the pod-------

Large White Lima. Somewhat smaller than the two preceding sorts. Well known.-

Small Lima, or Butter Bean. A well-known variety producing beans and pods about half the size of the preceding sorts, but ten days earlier and much more prolific. Our stock of this is very superior 
One ounce sows sixty feet of drill, 7 pounds to the acre. Ready to use in $\mathbf{4 0}$ to $\mathbf{7 5}$ days from sowing. In hot beds sow in January. In open ground in February, March, or April. For late beets sow in July or August.

Culture.-Beets thrive best in rather light, mellow and deeply-worked soil, which has been thoroughly enriched with well-rotted manure or fertilizer, which should be well mixed with the soil. Sow in rows nfteen inches apart and thin out the plants to four inches apart. For gardens the drills need not be more than twelve inches apart.

NOTE.-Our Beet Seeds are saved from selected, well-shaped roots, and are used extensively by market gardeners and truckers everywhere. Our prices per pound (and 5 pounds) are very low.

Packets of Beet Seeds are 5 cents each; 6 for 25 cents. Postage free on pkts., ozs., and $1 / 4$ lbs. For Seeds in bulk by mail, add 8 cents per lb. extra.

CROSBY'S IMPROVED EGYPTIAN (See cut). The ideal first early variety for sowing in hot beds or early planting outside. Crosby's Improved Egyptian is really the result of selection from the old Egyptian, and is almost universally pronounced the ideal market gardener's beet. It is very early, has small top, fine globe-shaped roots, can be pulled early, and is of excellent quality. (Note--Our stock of this is unsurpassed in quality.) Pkt. $5 \mathrm{c}$, oz. $10 \mathrm{c}, \mathrm{t} / 4$ lb. 15c, 1b. 60c, 5 lbs. and over 50c per $1 \mathrm{~b}$.

Detroit Dark Red.-A splendid deep red turnip beet, with very small upright tops, early maturing, and makes nice, round, finely-shaped roots. This is one of the finest of all for early market or home use, and will be found one of the best of all for forcing in hot beds. Pkt. $5 \mathrm{c}$, oz. $10 \mathrm{c}, \mathrm{T} / 41 \mathrm{~b} .15 \mathrm{c}$, 1b. $60 \mathrm{c}, 5 \mathrm{lbs}$. and over $50 \mathrm{c}$ per $1 \mathrm{~b}$.

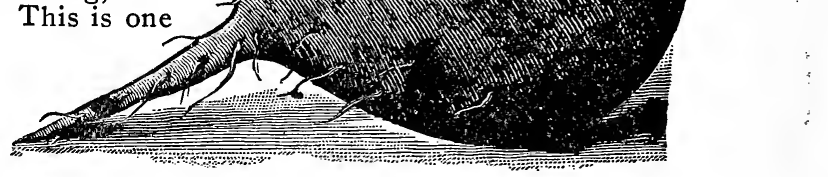

Crosby's Improved Egyptian Beet

EXTRA EARLY ECLIPSE.-(Blue Ribbon stock.) One of the most desirable and popular varieties of the early beets in our list. It is very early, globe-shaped, flesh dark and tender. Whether wanted for market or family use, for very early or main crop this will be found one of the most satisfactory of all. Pkt. 5c, oz. 8c, 1/4 lb. 15c, 1b. 50c, $5 \mathrm{lbs}$. and over $45 \mathrm{c}$ per lb.

Bastian's Early Blood Turnip.-Of quick and large growth, bright red color, not quite so deep as Blood Turnip. Very popular with gardeners for a second early or main crop. Pkt. 5c, oz. $10 \mathrm{c}, 1 / 4 \mathrm{lb}$. $15 \mathrm{c}, 1 \mathrm{~b} .45 \mathrm{c}, 5 \mathrm{lbs}$. and over $40 \mathrm{c}$ per $1 \mathrm{~b}$.

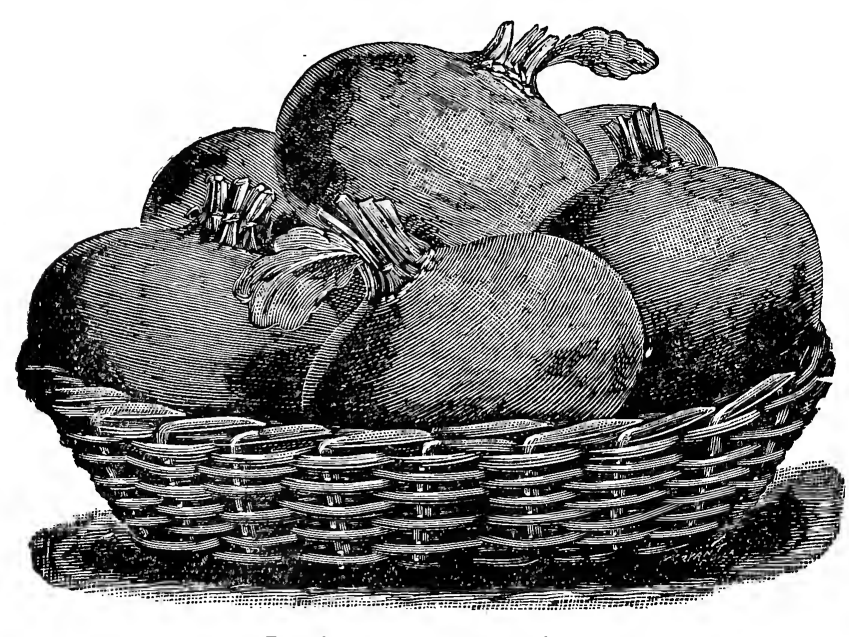

Bastian's Blood Turnip Beet
Extra Early Egyptian. Earliest of all; smooth flattish, deep red. Pkt. 5c, oz. 8 c, $1 / 4$ lb. 15 c, 1b. 45 c, 5 lbs. 40 c lb.

Improved Early Blood Turnip. Standard sort for main crop. Deep red, good size globe shape. Pkt. 5c, oz. 8c, $1 / 4$ lb. $15 \mathrm{c}, 1 \mathrm{~b}$. $45 \mathrm{c}$, 5 lbs. $40 \mathrm{c}$ lb.

EDMOND'S EARLY BLOOD TURNIP. Splendid dark red. For main crop, for market or table use. Pkt. 5 c, oz. 8 c, $1 / 4$ lb. 15 c, 1b. 45 c, 5 lbs. $40 \mathrm{c} 1 \mathrm{~b}$.

Extra Early Bassano or Sugar. Light red, very sweet, tender, flattish shape. Pkt. 5c, oz. 8c, $1 / 4$ lb. $15 \mathrm{c}, \mathrm{lb}$. $40 \mathrm{c}, 5$ lbs. $35 \mathrm{c} \mathrm{lb}$.

Half Long Blood. Fine for late crop or winter. Half long. Pkt. 5c, oz. 8c, $1 / 4$ lb. 15 c, 1b. 40 c, 5 lbs. $35 \mathrm{c}$ lb.

Long Smooth Blood. Late, dark flesh, deep roots, withstands drought and heat. Pkt. 5c, oz. $8 \mathrm{c}, 1 / 4 \mathrm{lb}$. $15 \mathrm{c}, 1 \mathrm{~b}$. 40 c, 5 lbs. 35 c lb.

All your seeds I have sown are doing their work correctly. Fayette County, Ky., May 4, 1908.

All your seeds I have sown are doing their work correctly. I am well satisfied with them this year. 


\section{BEETS-For Stock Feeding}

\section{3.}

\section{Mangels and Sugar Beets}

These yield enormously, sometimes making fifteen tons per acre, and are very nutritious and fattening, not only improving the health and general condition of stock, but greatly increasing both the quantity and quality of milk in cows. They are much superior in their feeding qualities to Turnips and are a much surer and larger yielding crop. Every farmer should grow them.

Culture.-Sow in April, May, or June, at the rate of six pounds to the acre, in rows two and a half to three feet apart, and when three inches high thin out to eight inches apart. Soak the seed 24 to 36 hours before sowing, and sow when the ground is moist. The roots hould be taken up before frost and packed away in the barn for winter use, or they can be put into piles or ridges five or six feet high, on a dry, sloping situation, and covered lightly with straw or plgh, on a dry, sloping situation, and covered lightly with straw or pine tags, with a light layer of earth on top. When freezing weather covering prevents heating. A protection of boards to shed away heavy rains is also desirable.

Mammoth Prize Long Red. Dark red, of immense size, single roots often weighing 20 to $25 \mathrm{lbs}$. The best for good, deep, loamy soil. Oz. 5c, r/4 lb. 10c, lb. 30c, 5 lbs. and over 25c per lb.

Yellow or Orange Globe. Grows almost entirely above ground, and is especially adapted to shallow soil, and is also, on this account, easily pulled. The roots are beautiful and symmetrical in shape, of large size, and splendid keepers. $\mathrm{Oz}$. $5 c, 1 / 4$ lb. 10 c, lb. 30 c, 5-1b. lots and over 25 c per lb.

Golden Tankard. Recommended on account of its milk-producing qualities. It is of rich yellow color, sweet flavor, and yielding heavy crops of fine-shaped roots. Oz. $5 \mathrm{c}, 1 / 4 \mathrm{lb}$. $10 \mathrm{c}, 1 \mathrm{~b}$. 30c, 5-1b. lots and over 25c per $1 \mathrm{~b}$.

Silesian Sugar. Highly prized on account of the large amount of sugar it contains. Very productive and a good keeper. Oz. 5c, $1 / 4$ lb. 10c, 1b. 30c, 5 lbs. and over 25 c per $1 b$.

Lane's Imperial Sugar. One of the most popular varieties for stock, and one which will succeed well throughout this latitude or farther South. Grows to a large size, is more like Mangel Wurzel in character, but the flesh is sweeter and tenderer; in fact sometimes used for table. Oz. $5 \mathrm{c}, \mathrm{r} / 4 \mathrm{lb}$. $10 \mathrm{c}, 1 \mathrm{~b}$. $30 \mathrm{c}, 5 \mathrm{lbs}$. and over $25 \mathrm{c}$ per $1 \mathrm{~b}$.

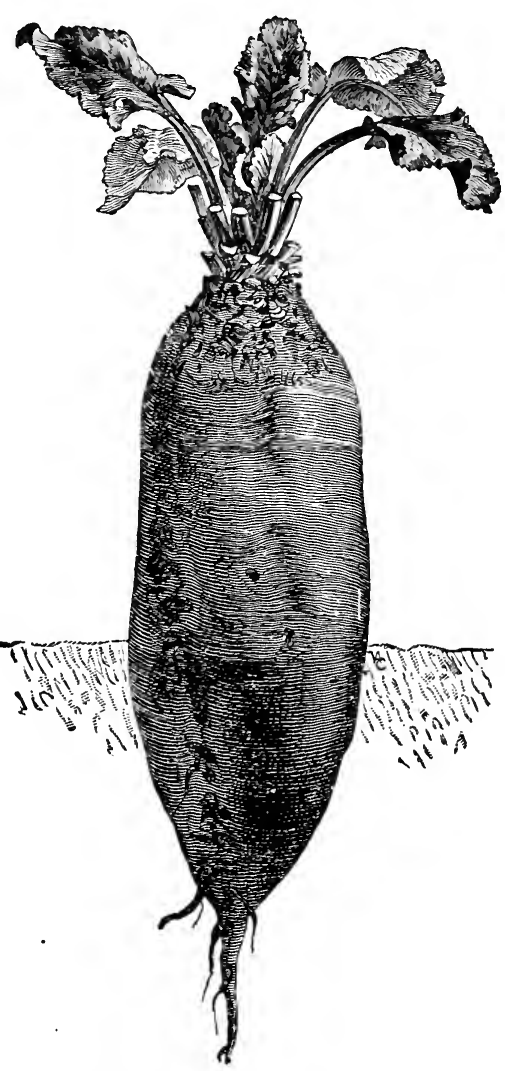

Mammoth Prize Mangel.

Broccoli. This vegetable resembles the Cauliflower, but is hardier, and, on this account, better for fall planting. Culture same as Cauliflower. INSECT REMEDIES-See under the head of Cabbage.

WHITE CAPE. Heads white, close and compact. A standard sort. Pkt. 10c, oz. 25c, 1/4 1b. 75c, lb. $\$ 2.50$.

\section{Brussels Sprouts}

One ounce produces 3,000 plants. 3 ounces to the acre.

A variety of the Cabbage family, and one of the most delicious vegetables. Plants grow from two to three feet high, and bear on their stalks or stems from 50 to 100 buds, which resemble miniature Savoy Cabbage heads one to two inches in diameter. Requires same treatment as late Cabbage, but when the buds are partially developed it is better to break down the leaves to allow the buds more room for development. Brussels Sprout. usually do best sown in May, transplanting in June.

PERFECTION. The best variety; is closely covered with large, compact sprouts. Pkt. 5 c, $1 / 2$ oz. 10 c, oz. 15 c, $1 / 4$ lb. 40 c, 1 b. $\$ 1.50$.

\section{THE WEEKLY MARKET GROWERS' JOURNAL}

Is a live publication, dealing with practical problems of gardening. Everybody who plants for commercial or private use should subscribe to it.

SUBSCRIPTION PRICE $\$ 1.00$ per year 52 issues.

AS A TRIAL OFFER, 10 weeks for 10 cents.

We desire every planter, large or small, to be a subscriber, as it means better methods, more economical production, and larger returns, besides intelligent knowledge of fertilization, cultivation, combating insects and diseases. Its original articles by the most thoroughly practical and upto-date men, and reliable information on production and markets, will save many times the subscription price.

\section{AS A SPECIAL OFFER FOR THIS YEAR ONLY}

With a $\$ 1.00$ order of seeds in packets and ounces only we will give a ten-weeks' subscription FREE. For a $\$ 5.00$ order for Vegetable or Flower Seeds, except at bushel rates, a full year's subscription-52 weeks free. 


\section{\& Blue Ribbon Cabbage Seeds}

\section{Select American Grown Stocks}

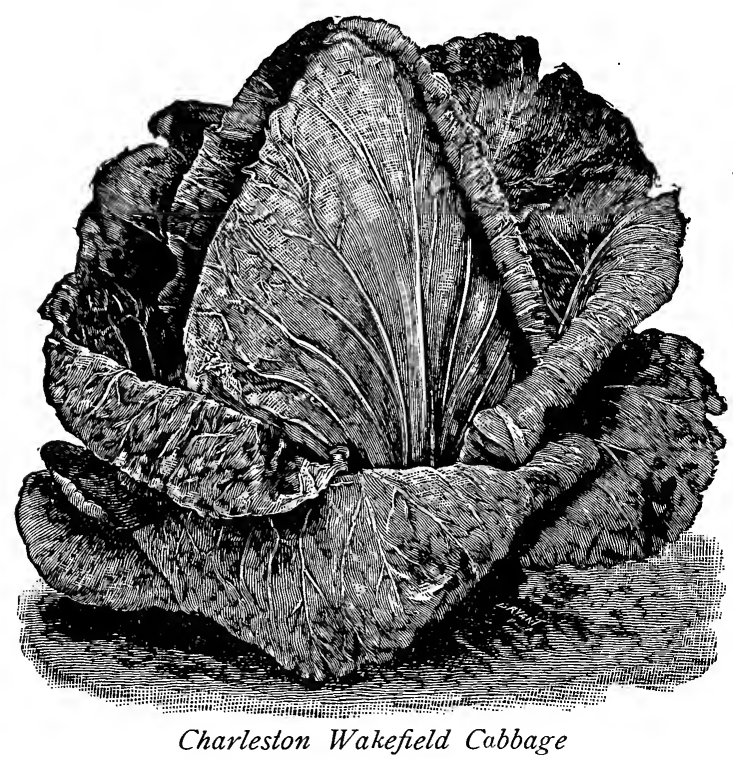

1 oz. makes 1,500 good plants; 6 ozs. sown will set an acre. For early use sow in frames in December, January, or February. For summer and early fall, sow out of doors in March. For late use sow in April, May, or June, according to period of maturity.

\section{A FEW RUIFS FOR PIANTING AND GROWING} CABBAGF SUCCFSSFUIIY.

Don't have the soil in the seed bed as rich as the field to which the Cabbage is transplanted, or the plants will be starved after transplantation.

Don't seed too thickly or force the growth too rapidly, or the plants will grow too tall, slim, and tender, and the growth be more seriously checked by adverse conditions.

Root deeply to resist drought. When setting out, plant up to the first leaf-stems. Supply plenty of moisture and manure or Acme High Grade Vegetable Fertilizer.

Don't sow the seed for a whole crop at one time. for plants of different age are differently affected by: adverse circumstances, and by division a planter will have a better chance to profit, at least from a part of his crop. his crop. deeply.

Insect Remedies.-For flea beetles in seed bed dust the plants with Tobacco Dust or Slug Shot. For cabbage worms dust with Slug Shot, or Paris Green diluted with flour or land plaster 1 to 60 . For terrapin or harlequin bugs hand-pick them. Where troublesome each year, sow spring Kale or Mustard as "catch crops" in between every tenth row, then destroy plants and bugs with coal oil.

\section{FIRST EARLY CABBAGES}

EARLY JERSEY WAKEFIELD. The standard first early Cabbage for the market grower. Heads conical, medium size, little outer foliage, and can be planted closely. Our strain of this is specially fine, being very early, of good size, and uniformly reliable heading qualities. Pkt. 5c, oz. 20 c, $1 / 4$ lb. 60 c, $1 \mathrm{~b}$. $\$ 2.00$.

LARGE, or CHARLESTON WAKEFIELD. (Blue Ribbon Stock.) The principal sort now planted by growers for early market, about one week later than Jersey Wakefield, but making much larger heads, sometimes weighing fifteen pounds. Our strain of this is unsurpassed, combining earliness, large size, uniformity in heading, and solidity. We recommend it for market, home use, or shipping. Pkt. 5c, oz. 20c, 1/4 1b. 60c, lb. $\$ 2.00$.

EARLY SPRING. The earliest flat head sort; about four days to a week later than Charleston Wakefield. Of fair size and solidity for so early a flat head sort, and especially suitable to light or well-drained soils, as it heads quite close to the ground. Quality excellent, and commands good prices on the market. Pkt. 5c, oz. 20c, 1/4 1b. 60c, 1b. $\$ 2.00$.

Early Winningstadt. Very early, conical-shaped, medium-sized, hard heads. Pkt. 5c, oz. $15 \mathrm{c}$, $\mathrm{r} / 4 \mathrm{lb} .40 \mathrm{c}, 1 \mathrm{~b} . \$ 1.40$.

Large York. An old standard sort, medium size, loose heads. Pkt. 5c, oz. $15 \mathrm{c}, 1 / 4$ lb. $40 \mathrm{c}, 1 \mathrm{~b}$. $\$ 1.40$.

Jefferson Co., Ky., July 27, 1908.

I am very much pleased with your cabbage seed and have been using it for a number of years. This year my Charleston Wakefield was especially fine.

I laid out twelve heads without particular selection, which I weighed, and the weight was a little over sixty-five pounds. I had them photographed and enclose photograph herewith.

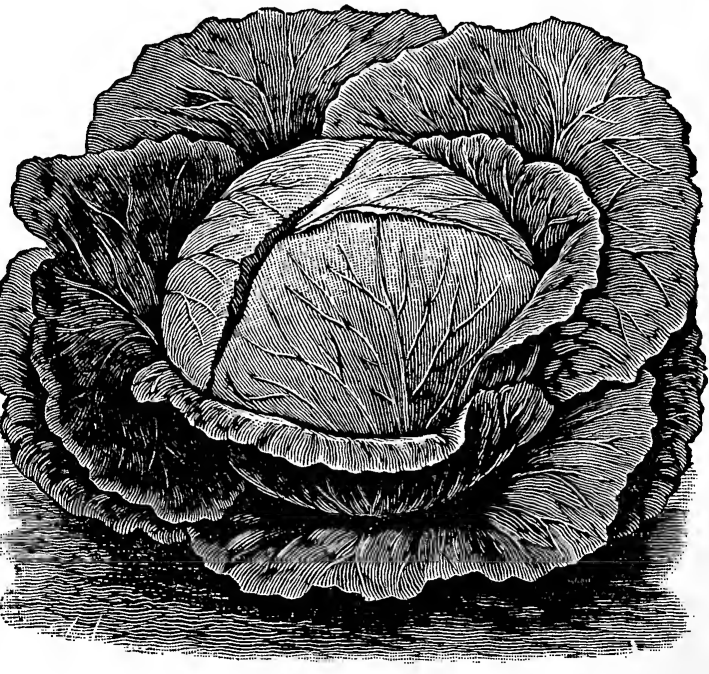

Early Spring Cabbage 
SOLID SOUTH. A magnificent cabbage, resembling the Early Summer, but is earlier, larger, more uniform, has fewer outside leaves, and is less liable to run to seed if sown in the fall. This is one of the important varieties for market gardeners and truckers, and is easily the best of the summer varieties. Well adapted for the family garden and for shipping. Pkt. $5 \mathrm{c}$, oz. $20 \mathrm{c}, 1 / 4$ lb. $60 \mathrm{c}$, ib. $\$ 2.00$.

LOUISVILLE DRUMHEAD. The favorite summer and fall variety among growers here, and becoming very popular in all localities, makes large, hard, solid heads of uniform size, is shortstemmed, has few outside leaves, and is of compact growth. We have selected home-grown seed of this variety from the best and most careful growers here; also offer Northern grown seed from stock procured here.

Home-grown Seed. Pkt. 5c, oz. 25c, I/4 lb. 85 c, lb. $\$ 3.00$.

Northern-grown Seed. Pkt. 5c, oz. 20c, I/4 lb. 60 c, lb. $\$ 2.00$.

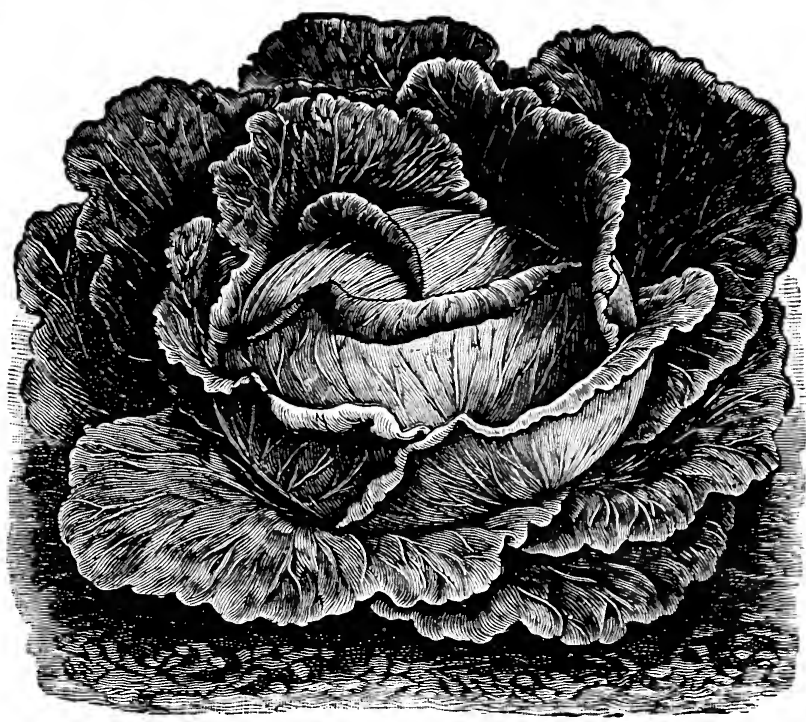

Solid South Cabbage

EARLY FLAT DUTCH. Short-stemmed, flattish solid heads, very reliable heading. Pkt. 5c, oz. $15 \mathrm{c}, \mathrm{I} / 4 \mathrm{lb}$. 50c, 1b. $\$ 1.50$.

ALL HEAD EARLY. Second early, deep flat solid heads. Pkt. 5c, oz. 15c, r/4 lb. 50c, 1b. $\$ 1.50$.

EARLY SUMMER. Splendid second early, large round heads. Popular with gardeners everywhere. Pkt. $5 \mathrm{c}$, oz. $15 \mathrm{c}, 1 / 4 \mathrm{lb}$. $50 \mathrm{c}, \mathrm{lb}$. $\$ 1.50$.

ALL SEASONS. A good variety for general use summer or fall. Heads round, flattened on the top, large and solid. Pkt. 5c, oz. $20 \mathrm{c}, 1 / 4 \mathrm{lb} .60 \mathrm{c}, 1 \mathrm{~b} . \$ 2.00$.

HENDERSON'S SUCCESSION. Similar to All Seasons, but a little later, fine sure-heading sort, very solid, and a good keeper. Pkt. $5 \mathrm{c}$, oz. $20 \mathrm{c}, \mathrm{t} / 4 \mathrm{lb}$. $60 \mathrm{c}, \mathrm{lb} . \$ 2.00$.

EARLY DRUMHEAD. Similar to Early Summer. Pkt. $5 \mathrm{c}$, oz. $15 \mathrm{c}, 1 / 4 \mathrm{lb} .50 \mathrm{c}, 1 \mathrm{~b} .1 .50$.

SUREHEAD. Fine for late crop. Deep, round, thick heads. Pkt. 5c, oz. $15 \mathrm{c}, 1 / 4$ ib. 50c, lb. $\$ 1.50$.

LARGE LATE DRUMHEAD. Rounder on the top than Flat Dutch, and not quite so short-stemmed. Good, large heads. Pkt. 5c, oz. 15c, 1/4 lb. 50c, 1b. $\$ 1.50$.

MAMMOTH ROCK RED. The largest, surest heading red cabbage. Fine for pickling and kraut. Pkt. 5c, oz. $20 \mathrm{c}, 1 / 4 \mathrm{lb} .60 \mathrm{c}, 1 \mathrm{~b} . \$ 2.00$.

DANISH BALL-HEAD, OR HOLLANDER. A splendid, large, hard-heading variety for late, and used most extensively in the winter cabbage districts. Has few outside leaves, produces round, white heads, crisp and tender, and a splendid keeping sort. The best for kraut and pickling, evaporating, and fine for market, storing, and shipping. Pkt. 5c, oz. 20c, $1 / 4 \mathrm{lb} .60 \mathrm{c}, 1 \mathrm{~b}$. $\$ 2.00$.

PRIZE HEAD' LATE FLAT DUTCH. This we have always found a reliable and sure header, producing large, round, solid heads, flat on the top, of low growing habit, and few outer leaves. There are various strains of Flat Dutch Cabbage offered, but if you want the best of all, be sure and get our "Prize Head" stock. Pkt. 5c, oz. 15c, 1/4 lb. 50c, 1b. $\$ 1.50$.

A M E R I C A N PERFECTION DRUMHEAD SAVOY. The be st and largest heading of the Savoy Cabbage. Few people seem to know the delicious flavor of Savoy Cabbage. It is far superior to the flat-leaved sorts, and as tender as cauliflower after frost. Should be in every private garden. Pkt. 5 c, oz. 20 c, $1 / 4$ lb. 60 c,
lb. $\$ 2.00$.

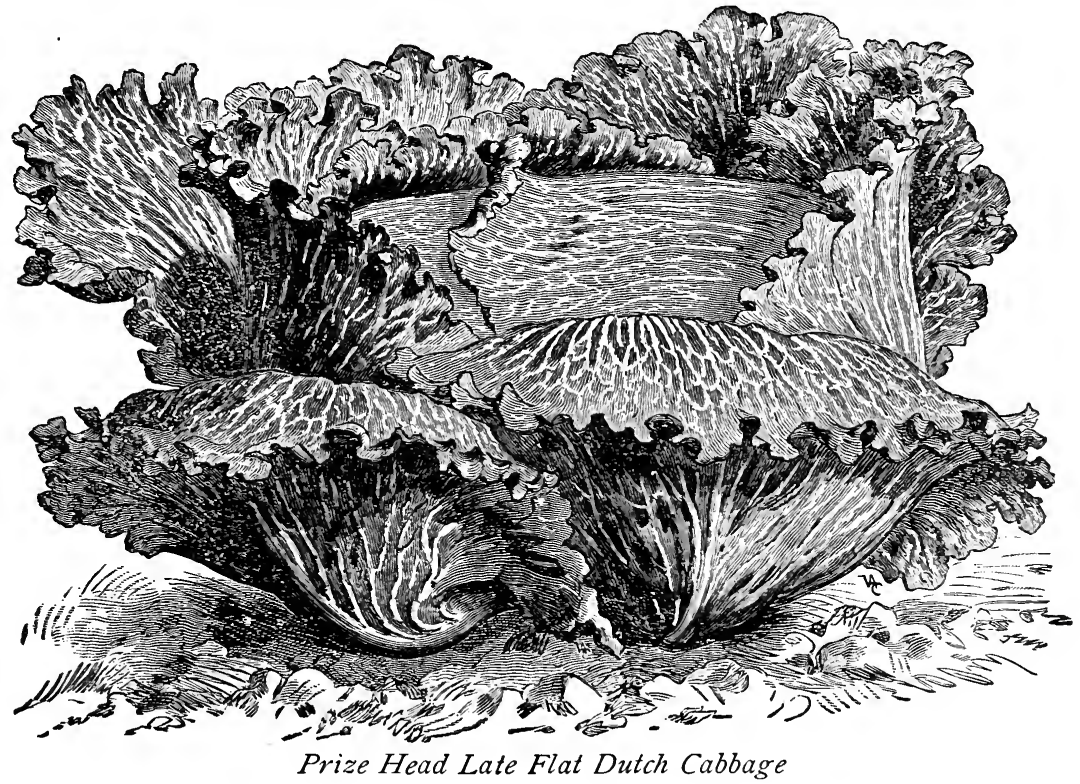




\section{CARROT}

$1 \mathrm{oz}$. sows 100 feet of drill; three lbs. to the acre. Ready for the table in 40 to 70 days from germination. Sow from March till June.

Culture-Carrots do best on a light, well-manured, deeplyworked soil. Sow in drills twelve inches apart and half an inch deep, and afterwards thin out to three to six inches apart. To keep for winter, pack the roots in moderately dry earth or sand in the cellar, or they can be pitted out of doors.

Packets of all varieties 5c each. All bulk seed by mail add $8 \mathrm{c}$ per lb. for postage.

EARLY SCARLET HORN. (45 days.) One of the best for early planting out of doors. Roots top shaped, a true half-long. Skin and flesh orange red. Pkt. 5c, oz. 10 c, $1 / 4$ lb. 25 c, 1b. 75c.

CHANTENAY. A medium early heavy yielding variety of orange red color, of crisp and tender flesh. Fine for table use or as a field carrot for stock. Pkt. 5c, oz. $10 \mathrm{c}, 1 / 4$ 1b. 25c, 1b. 75c.

OXHEART, or GUERANDE. This is deserving of general cultivation. It grows three or four inches in diameter, is early, nearly oval in shape, and finest quality. Pkt. $5 \mathrm{c}$, oz. $10 \mathrm{c}, 1 / 4$ lb. $25 \mathrm{c}, 1 \mathrm{~b} .75 \mathrm{c}$.

SCARLET INTERMEDIATE. A fine, handsome carrot, in form midway between the long Orange and Early Scarlet Horn. The roots are large, uniform, and symmetrical, with scarcely any core. Splendid either for garden or

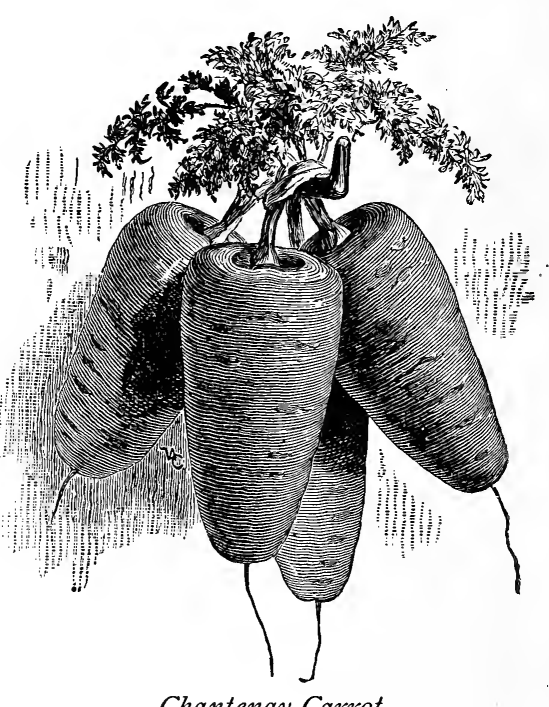

Chantenay Carrot field culture, and very popular both for market or family table. Pkt. 3c, oz. 7c, 1/4 1b. 25c, 1b. 75c.

HALF LONG DANVERS. Thick growing, good quality, and makes very satisfactory yields. Pkt. $5 \mathrm{c}$, oz. $10 \mathrm{c}, \mathrm{1} / 4$ lb. $25 \mathrm{c}$, 1b. $75 \mathrm{c}$.

HALF LONG SCARLET. (Stump Rooted.) Bright orange colored flesh, easily pulled, and well adapted to shallow soil. Pkt. 5c, oz. 10c, 1/4 1b. 25c, 1b. 75c.

IMPROVED LONG ORANGE. The most popular main-crop sort in cultivation. The roots are long and tapering, and of a deep orange color, and free from side roots. One of the best winter sorts, and is largely grown for table, market, and stock. Pkt. 5c, oz. 8c, 1/4 lb. 20c, 1b. 65c.

LARGE WHITE BELGIAN. (For Stock.) Grows to an enormous size, making very large yield of most nutritious and fattening feed for stock. Oz. $5 \mathrm{c}, \mathrm{I} / 4 \mathrm{lb} .15 \mathrm{c}, 1 \mathrm{~b} .40 \mathrm{c}, 5 \mathrm{lbs}$. at $35 \mathrm{c}$ per $1 \mathrm{~b}$.

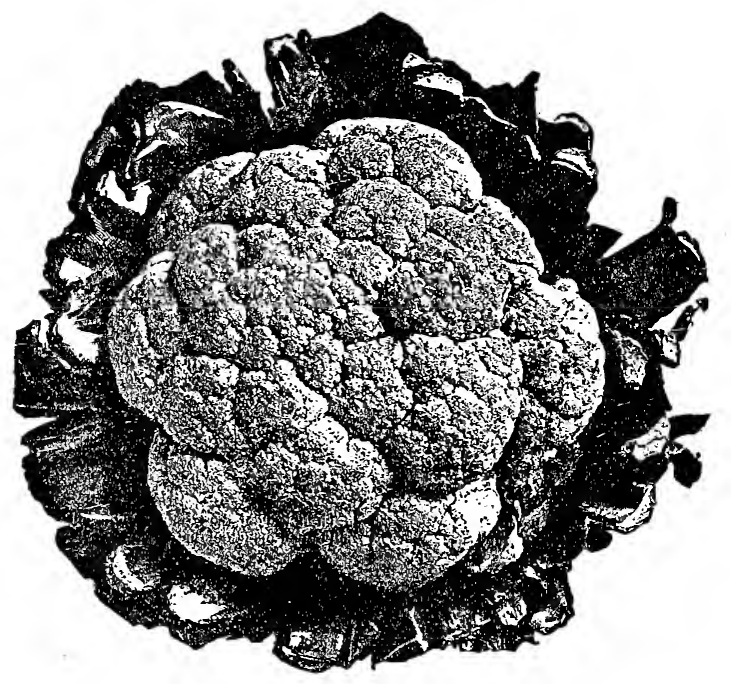

Blue Ribbon Snowball Cauliflower

\section{CAULIFLOWER}

I/4 oz. produces about 500 plants. 3 oz. make enough to set out an acre. Mature heads in 90 to 100 days from the planting.

Culture.-For early forcing, sow in December or January, or for spring planting, in January or February in gentle hot beds or cold frames. For field culture sow and give the same treatment as for early or late cabbage. They require plenty of manure, moisture, and good culture. After they begin to head, fasten the leaves together over the top to protect from the sun and keep white.

BLUE RIBBON SNOWBALL. This we consider the very finest strain of Snowball Cauliflower. It is grown for us by one of the most careful Denmark growers, and will produce heads of snowy whiteness and unexcelled quality. Dwarf compact growth, exceedingly early, very hardy, and under favorable conditions every plant will make a fine, solid head. The best for forcing or early field crop. Pkt. 20c, I/4 oz. $85 \mathrm{c}, 1 \mathrm{oz}$. $\$ 3.00,1 / 4$ lb. $\$ 10.00,1 b$. $\$ 36.00$.

Danish Giant. An extra large and reliable sort which is somewhat later than the above, and especially valuable for outside planting, as it withstands dry weather and forms fine heads under adverse conditions. Pkt. 20c, I/4 oz. 85c, oz. $\$ 3.00,1 / 41 b . \$ 10.00,1 b$. $\$ 36.00$.

Earliest Snowball. A fine strain for field crop, early or late. Pkt. 10c, 1/4 oz. 60c, oz. $\$ 2.00,1 / 41 b$. $\$ 7.00$.

Extra Early Dwarf Erfurt. Many gardeners use this for forcing and for outside. Head a little larger than Snowball, not quite as early. Pkt. 10c, 1/4 oz. 60c, oz. $\$ 2.00$, 1/4 1b. $\$ 7.00$.

CAULIFLOWER PLANTS in Season. Prices about $25 \mathrm{c}$ per dozen; $\$ 1.50$ per 100 . Special prices in large lots. No plants sent by Mail. 


\section{e CELERY}

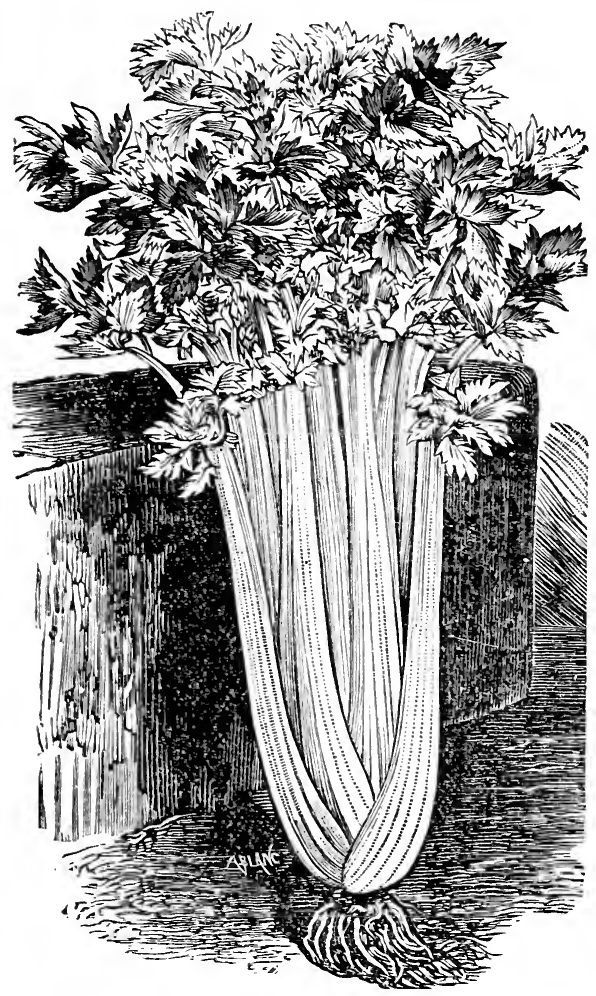

Improved White Plume Celery

One ounce sows about 100 feet and produces about 8,000 good plants. Four ounces to set one acre. Matures in 120 to 150 days, according to season and location.

Culture.-Sow in February, March, or beginning of April in rows in fine, rich soil, and, if dry enough, press the soll firmly with a roller or the back of a spade. Keep the seed bed well watered, as Celery germinates very slowly. Transplant from June to August. Celery does best in a moist, mucky soil, and in situations $w$ here plenty of water is abundant in the soil. It can be planted in single or double rows, earthing up as it grows two or three times, and in doing this care should be taken not to let the earth get into the heart of the plant. When severe cold weather comes take up and transplant solidly in a bed close together and cover gradually with leaves, hay, or straw, as necessary to prevent freezing.

IMPROVED WHITE PLUME. The favorite sort with most gardeners on account of its earliness and requiring very little earthing up. It blanches very easily, is of fine, attractive appearance, medium size, but not so good flavor or as tender as other sorts. Our stock of this is especially fine, producting fine, solid stalks. Pkt. 5c, oz. 20c, 1/4 1b. 60c, 1b. $\$ 2.00$.

GOLDEN ROSE, or PARIS ROSE RIBBED CELERY. An attractive self-blanching sort, of beautiful rich, golden color, combined with a warm, rosy pink on its outer ribs. The stalks are very thick, solid, and brittle; and very finest flavored celery. Not quite so early as White Plume, but a better keeping sort and far better quality. Pkt. 5c, oz. 25c, 1/4 1b. 85c, 1b. $\$ 3.00$.

WINTER QUEEN. Highly regarded by growers for late keeping, preserving its solidity and tenderness very late in the spring. Vigorous in growth and of attractive appearance. Pkt. 5c, oz. $20 \mathrm{c}, 1 / 4 \mathrm{lb} .60 \mathrm{c}, 1 \mathrm{~b}$. $\$ 2.00$.

Giant Pascal. Large and robust in growth, but very solid. Fine late sort. Pkt. $5 \mathrm{c}$, oz. $15 \mathrm{c}, \mathrm{I} / 4 \mathrm{lb}$. $40 \mathrm{c}, 1 \mathrm{~b} . \$ 1.25$.

Pink Plume. Similar to White Plume, except in color, and better flavor. Pkt. 5c, oz. $15 \mathrm{c}, \mathrm{I} / 4 \mathrm{lb}$. $50 \mathrm{c}, \mathrm{lb} . \$ 1.75$.

GOLDEN SELF BLANCHING. The best of all for private gardens. Dwarf growing, requires little earthing, and of finest quality and flavor. Pkt. 5c, oz. $25 \mathrm{c}, 1 / 41 \mathrm{~b} .85 \mathrm{c}, 1 \mathrm{~b} . \$ 3.00$.

Crawford's Half Dwarf. A superior sort popular for market. Blanches creamy white. Pkt. 5c, oz. $15 \mathrm{c}, \mathrm{s} / 4.1 \mathrm{~b} .35 \mathrm{c}, 1 \mathrm{~b}$. $\$ 1.00$.

Celeriac, or Turnip-Rooted Celery. Roots used only, boiled or raw. Has a delightful flavor. Pkt. 5 c, oz. 15 c, $1 / 4$ lb. 35 c, 1 b. $\$ 1.00$.

CELERY PLANTS Supplied in Season. Varieties: White Plume, Giant Pascal, and other sorts. Prices about 50c per 100, $\$ 4.00$ per 1,000. Special prices in large lots. No plants sent by mail.

Collare This is highly prized by the people of the Southern States, where it is used as $11210 S$ Greens. It grows like Cabbage, but does not form heads, but yields abundantly. Collards also are excellent feed for stock.

Culture and Insect Remedies same as for Cabbage.

NORTH CAROLINA SHORT STEM. Has a very short stem, large spreading leaves, very hardy, withstanding drought in summer and cold in winter. Its flavor and cooking qualities are the very best, and it has unquestionably proved far superior to any Collards in cultivation. Pkt. $5 \mathrm{c}$, oz. $10 \mathrm{c}, \mathrm{x} / 4$ lb. 30c, lb. $\$ 1.00$.

TRUE GEORGIA. The old standard sort for use in the South. Pkt. 5c, oz. 10c, 1/4 1b. 25c, 1b. 75c. Corn Salad An excellent salad for winter and spring. Sow in September in drills 9 will germinate better. When severe weather comes on cover lightly with clean straw or leaves. Can also be sown early in spring.

LARGE SEEDED. Round leaved; the best variety. Pkt. 5c, oz. 10c, 1/4 1b. 20c, $1 \mathrm{~b} .60 \mathrm{c}$.

\section{POP CORN}

MAPLEDALE PROLIFIC. Pure white, smooth grains. Pkt. 5c, pt. 15c, qt. 25c.

WHITE RICE. White pointed grains, popular. Pkt. 5c, pt. 15c, qt. 25c.

QUEEN'S GOLDEN. Large, handsome, yellow grains and ears; pops pure white. Pkt. 5c, pt. 15c, qt. $25 \mathrm{c}$. 


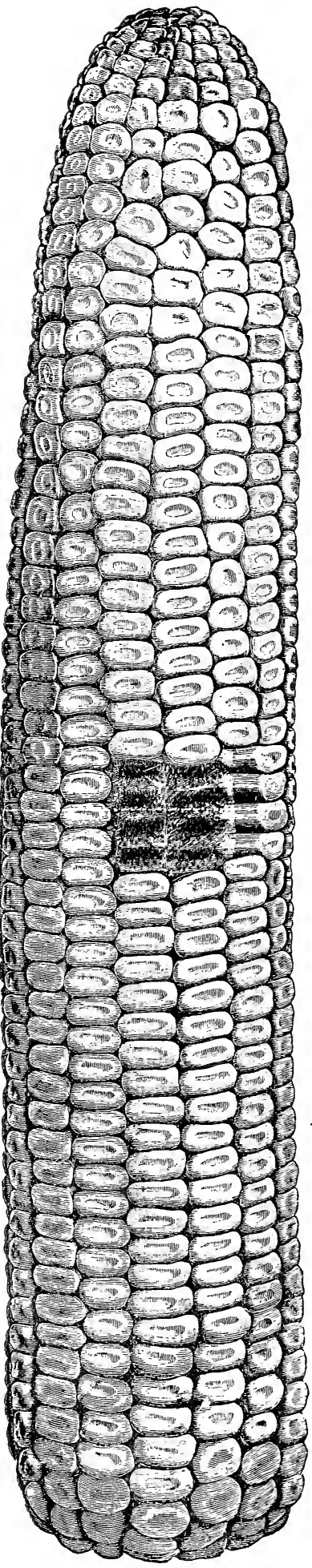

Early Northern Field Corn
$1 \mathrm{pt}$. to 200 hills; 6 to $8 \mathrm{qts}$. to the acre. Plant for succession every two weeks from April till July. Ready for table in from sixty to ninety days from planting.

Culture.-Flant the Early Corns in well-manured ground last of March or early in April. Sugar Corn should not be planted until the ground gets warm. Cultivate deeply and often. The early varieties of Sugar Corn can be planted during July for late roasting ears.

Packets of all varieties of Corn 5c each, postpaid. In bulk, add 15c per quart, $10 \mathrm{c}$ per pint if to be sent by mail.

The following four varieties are not Sugar Corns, but are valuable on account of their earliness, especially for early market or very late planting:

\section{E X T R A E A L Y} ADAMS. The earliest of all, bearing small ears close to the ground. Usually profitable and desirable on account of the extreme earliness. On ears, doz. $30 \mathrm{c}, 100 \$ 2.50$. Shelled, pkt. 5c, pt. 10c, qt. $15 \mathrm{c}, 4$ qts. $45 \mathrm{c}$, pk. $85 \mathrm{c}$, bu. $\$ 3.00$.

EARLY ADAMS. A little later, larger growth, and producing larger ears than Extra Early Adams. On ears, doz. 30c, 100 $\$ 2.50$. Shelled, pkt. $5 \mathrm{c}$, pt. 10 c, qt. $15 \mathrm{c}, 4$ qts. 40 c, pk. $75 \mathrm{c}$, bush. $\$ 2.50$.

E A R L Y NORTHERN WHITE FIELD. Th e most popular of all for second early in this locality, and the main sort for very late planting. Ears symmetrical, good size, having straight rows, and corn is of fine quality. On ears, doz. 30 c, per 100 ears $\$ 2.00$. Shelled, pkt. $5 \mathrm{c}$, pt. $10 \mathrm{c}$, qt. $15 \mathrm{c}, 4$ qts. 35 c, pk. 65c, bush. $\$ 2.00$.

EARLY RED DRIVER. Similar to above, of deep carmine color when dry, but white when in cooking st a g e. Excellent yielder, good for market, table, or as a field crop. Shelled, pkt. $5 \mathrm{c}$, pt. $10 \mathrm{c}$, qt. $15 \mathrm{c}, 4$ qts. $30 \mathrm{c}, \mathrm{pk} .50 \mathrm{c}$ bu. $\$ 1.75$.

\section{Sweet or Sugar Corn.}

Unquestionably superior to other sorts. All private gardeners should use these exclusively, and market gardeners will find them more profitable for main crop than field sorts, as they produce more ears, besides commanding a $25 \%$ better price.

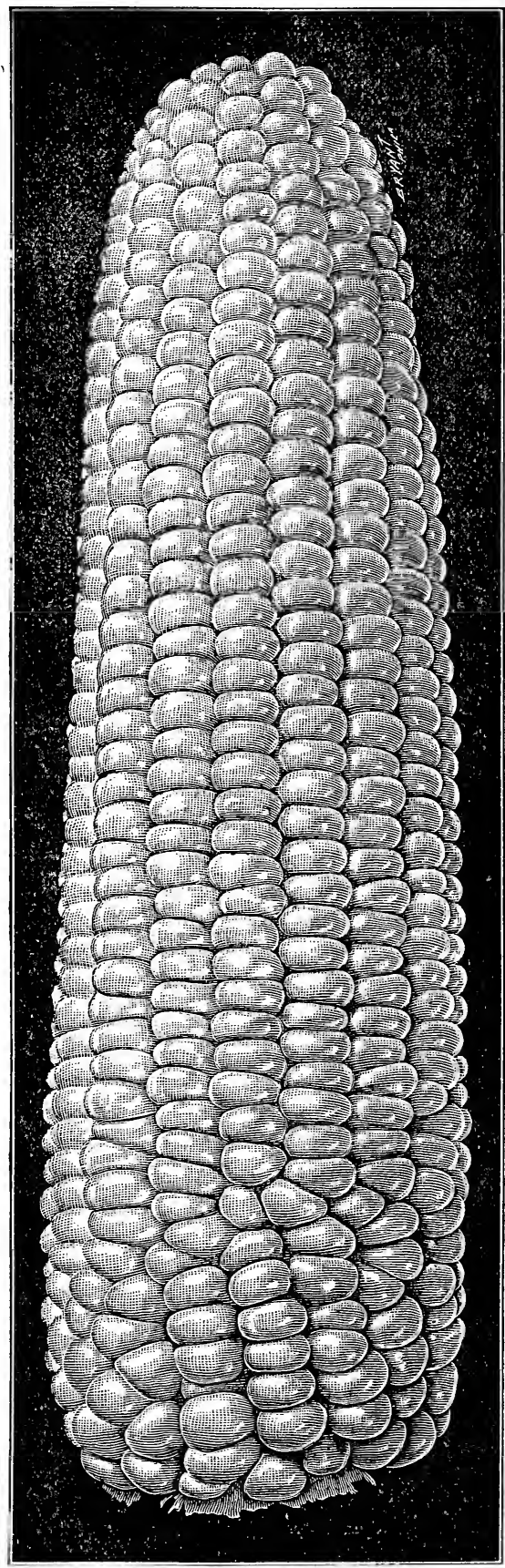

Mammoth White Cory Corn

MAMMOTH WHITE CORY. A good extra early, producing medium-sized ears of finest quality. Pkt. 5 c, pt. 10 c, qt. 20 c, 4 qts. 60 c, pk. $\$ 1.00$, bush. $\$ 3.50$.

BLACK MEXICAN. The sweetest of all. Very early, good size, and good yielding. Pkt. 5c, pt. 10c, qt. 20 c, 4 qts. 60 c, pk. $\$ 1.00$, bush. $\$ 3.50$. 


\section{CORN-Garden Varieties-Continued}

CROSBY'S EARLY SWEET. A little later, with ears longer than either of above sorts, and more symmetrical. Deep grains and fine for market or home use. Pkt. 5c, pt. 10c, qt. 20c, 4 qts. 60 c, pk. $\$ 1.00$, bush. $\$ 3.50$.

COUNTRY GENTLEMAN. A favorite second early or main-crop variety with all private gardeners for its tenderness, delicacy, small, deep grains, and sweetness. The ears are of fair size, frequently three or four to the stalk. Pkt. 5c, pt. 10c, qt. 20 c, 4 qts. 75 c, pk. $\$ 1.25$, bush. $\$ 4.50$.

STOWELL'S EVERGREEN. Although a late variety, this has long been a favorite. It makes goodsized ears, has very deep grains, and will remain in the green state longer than any other sort. This we regard as one of the best for main crop, and is exceptionally tender and sugary. Pkt. 5 c, pt. 10 c, qt. 20 c, 4 qts. 60 c, pk. $\$ 1.00$, bush. $\$ 3.50$; on ears, 40 c per doz.

LATE MAMMOTH SUGAR. This is the latest but largest of all the Sugar Corns. The ear grows to an immense size, and are of fine quality and flavor. Pkt. 5c, postpaid; pt. 10c, qt. $20 \mathrm{c}, 4 \mathrm{qts}$. 60 c, pk. $\$ 1.00$, bush. $\$ 3.50$; on ears, per doz. 40 c.

FIELD CORNS. For description, prices, etc., see Field Seeds.

\section{CUCUMBER - Finest Select Stocks CROPS SHORT}

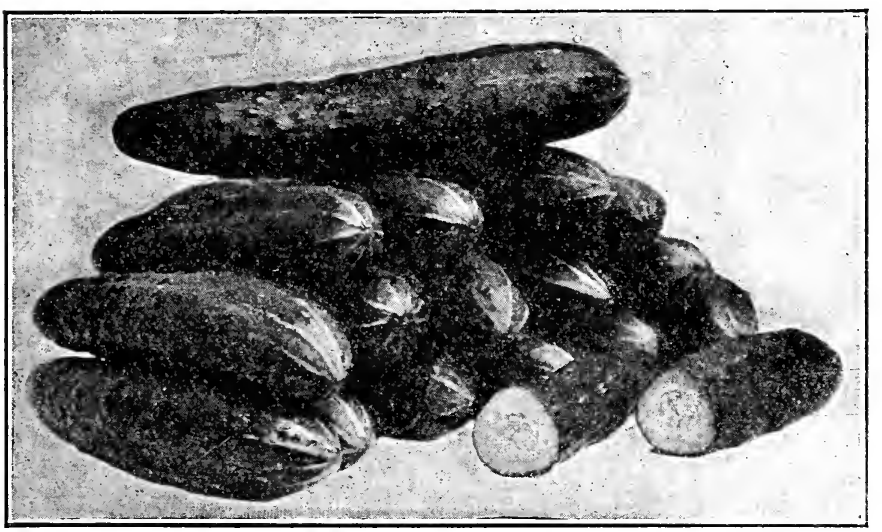

Davis Perfect Cucumber

1 ounce is sufficient for 50 hills. 2 lbs. to the acre. Plant in April or May for early crop. Ready for the table in from 50 to 75 days from planting.

Culture.-For very early field crop, plant in hot beds, in pots or small paper boxes, or on pieces of sod, grass side down, so that they can be readily transplanted, or plant in the open ground as soon as the in the open ground as soon as the the end of April or during May, in hills about four feet apart each way. Cucumbers may be protected from threatened frost by hand glasses or even by a paper held down at the corners by a handful of earth. The hills should be previously prepared by mixing a shovelful of well rotted manure or a small handful of Acme manure or a small handful of Acme soil. For main field crop, plant in May and put about ten seeds in each hill, and when all danger of insects is past, thin out to four. The fruit should be gathered when large enough, whether wanted or not, for if left to ripen on the vine it destroys the productiveness. For late pickling, lant in June or July.

Insect Remedies.-For spotted and striped beetles the remedy is Tobacco Dust sprinkled liberally on the vines and hills while the dew is on. For the cucumber borer, which bores into the cucumbers, handpicking and destroying infested cucumbers is the only remedy.

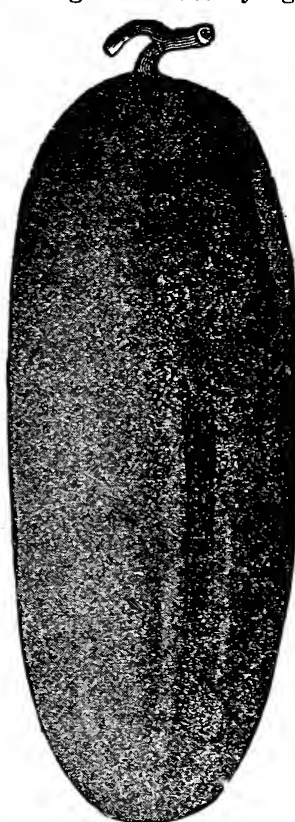

Imp. Ey. White Spine
DAVIS' PERFECT CUCUMBER. This is more on the type of an English Frame Cucumber, containing very few seeds. The color, a dark green slightly tipped with white at the end, remains in a fresh condition longer than any other sort, and sells readily at considerably above ordinary sorts such as White Spine, Long Green, etc. The vines are very vigorous, therefore should not be planted too close or it will not do so well; five feet apart is close enough. In growing for outside it produces good crops, and as there is great resemblance to the hot-house cucumber, it commands better prices than the ordinary sorts. Pkt. 5c, oz. $15 \mathrm{c}, \mathrm{I} / 4$ 1b. $50 \mathrm{c}, 1 \mathrm{~b}$. $\$ 1.50$.

IMPROVED EARLY WHITE SPINE. The favorite variety with nearly all gardeners and truckers for early and main crop. The fruits are smooth, of good shape, splendid deep green color, shading to whitish at the tip end. Our stock of this is extra fine and well adapted either for growing in greenhouses, frames, or outside, for early or late planting. A splendid sort for pickles. Pkt. 5c, oz. $10 \mathrm{c}, 1 / 4$ lb. 30c, 1b. $\$ 1.00$.

ARLINGTON WHITE SPINE. A selection from the White Spine, being more pointed at each end. The young fruits are usually crisp and tender, of dark green color, so that this variety is considered by many to be the best for small pickles. Pkt. 5c, oz. 10c, $1 / 4$ lb. 30c, 1b. $\$ 1.00$.

KLONDYKE. This sort is becoming a leader among growers for market for early or late crops. Fruits are of Improved White Spine shape, do not show quite as much whiteness at the tip ends, are long, hold their deep green color longer than any other sort, and of unsurpassed

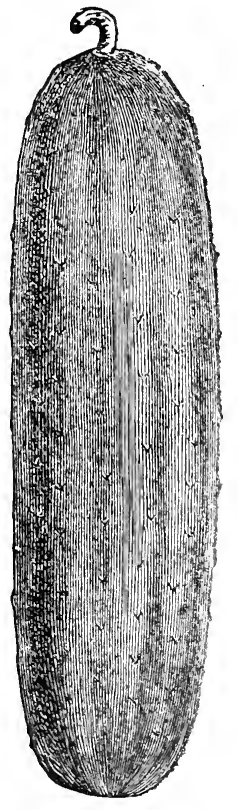

Imp. Long Green 


\section{CUCUMBER-Continued}

quality. Color deep rich green. Very productive and extremely early for Pkt. Oz. 1/4 lb. Lb.

SO fine a variety-
IMPROVED LONG GREEN. A popular cucumber for all purposes, being highly prized for family use and pickling. Fruit about 12 inches long when fully grown. Of a dark green color, firm and crisp --

GREEN PROLIFIC, OR BOSTON PICKLING. One of the best for pickling; dark green, very productive, and of uniform small size $\begin{array}{lllll}5 & 10 & 30 & 1 & 00\end{array}$ ling cucumber. Very popular with Chicago growers, and more largely planted than any other sort in that vicinity. Fruit medium length, pointed at each end. Color deep green, flesh crisp and tender --.--

CUMBERLAND. Particularly valuable for pickles, besides combining fine qualities, which make it an excellent table sort. A strong, vigorous grower, ex-

EARLY FRAME, OR EARLY SHORT GREEN. Excellent for table use and pickling. Plants vigorous and very productive. Fruits straight, medium length and of good quality

JERSEY PICKLING. Intermediate between Long Green and Green Prolific, forming long, slender, cylindrical fruits of dark green color

GHERKIN, OR BURR. A small, oval-shaped, prickly variety, used exclusively for pickles, for which it is very desirable.

$10 \quad 25 \quad 85$

\section{CRESS OR PEPPER GRASS}

Curled. Used for salad. Oz. 5c, I/4 lb. 15c, lb. $40 \mathrm{c}$.

Water. For garnishing and salads. Pkt. 5c, oz. $30 \mathrm{c}$.

Dandelion Cultivation same as Lettuce.

French. Used for salad. Pkt. 5c, oz. 20c, $1 / 4 \mathrm{lb}$. 60 c, 1b. $\$ 2.00$.

\section{GOURDS}

See Flower Seeds.

\section{HERBS}

Culture.-Sow in April in rows 18 inches apart. Cut when in bloom, wilt in the sun and dry in the shade.

Packets of all varieties 5c each; 6 for 25c;

12 for $50 \mathrm{c}$, postpaid.
Anise. A remedy for dyspepsia, colic, and stomach trouble. Per oz. $10 \mathrm{c}$.

Basil, Sweet. For flavoring soups, sauces, etc. Oz. 15c.

Dill. The seeds and plant are mostly used with pickles to make "Dill Pickles." Oz. 10c, 1/4 lb. $20 \mathrm{c}, 1 \mathrm{~b} .65 \mathrm{c}$.

Lavender. Used for perfuming clothes; has a delightful odor. $\mathrm{Oz} .15 \mathrm{c}, \mathrm{r} / 4$ lb. $40 \mathrm{c}$.

Marjoram, Sweet. For flavoring and seasoning sausages. Oz. $15 \mathrm{c}, \mathrm{r} / 4$ 1b. $40 \mathrm{c}$.

Sage. Broad-leaved English. For flavoring sausage, etc. Oz. $15 \mathrm{c}, 1 / 4$ lb. $40 \mathrm{c}, 1 \mathrm{~b} . \$ 1.25$.

Summer Savory. For dressings and soups. Oz. $10 \mathrm{c}, \mathrm{t} / 4$ lb. $30 \mathrm{c}$.

Thyme. Used both green and dry. Should be in every garden. Oz. 30c; $1 / 4$ lb. $75 \mathrm{c}$.

\section{ENDIVE}

A very delightful and refreshing vegetable; used mostly for salad and a substitute for lettuce, which it resembles. Endive may be grown at any season of the year, but is generally used only late in the fall.

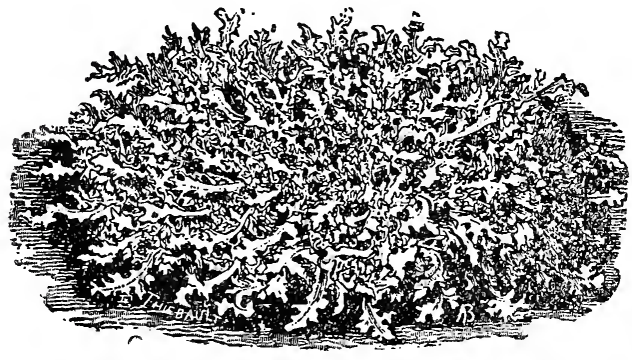

Green Curled Endive

Culture.-Sow in August in drills eighteen inches apart, and when large enough thin out to one foot apart. When nearly grown, tie up the outer leaves to blanch the heart. In dry seasons give plenty of water.

GREEN CURLED. This is one of the hardiest and best varieties for general use. The deep green leaves are beautifully cut and curled, easily blanched and becomes very crisp, tender, and fine flavored. Pkt. 5c, oz. 15 c, $1 / 4$ lb. 35c, 1b. $\$ 1.00$.

Large Green Curled. A large, coarse, strong-growing variety, which, when tied up, blanches well. Pkt. 5c, oz. $20 \mathrm{c}$, 1/4 lb. 50c, lb. $\$ 1.75$.

Owen County, Ky., Aug. 26, 1908. I received your price list to-day. Have been buying from you for some time; have always got good
seed; could buy cheaper, but you have always sent me good seed.

Robertson County, Tenn. Feb. 10, 1908. I have always found your seed good, and will want more later in the season. 


\section{EGG PLANT}

$1 \mathrm{oz}$. produces 1,500 plants. $4 \mathrm{oz}$. to the acre. Ready for the table in 120 days from sowing.

Culture.-In February or March sow in hot-beds and keep warm. When two inches high, transplant to pots or to good rich soil. About the middle of May set out three feet apart each way, and protect from bugs by dusting lightly with Slug Shot.

NEW YORK IMPROVED PURPLE. One of the best and largest varieties in cultivation. Our strain of this variety is especially fine. The plant is robust, low-growing, branching freely, and bears large, oblong-shaped purple fruits. There are many varieties of Egg Plant offered, but we consider this superior to any other. Pkt. $5 \mathrm{c}$, oz. $30 \mathrm{c}, \mathrm{r} / 4 \mathrm{lb} .85 \mathrm{c}$, lb. $\$ 3.00$.

IMPROVED SPINELESS. This variety is almost entirely free from spines or thorns, and on this account more easily gathered. The fruit resembles New York Improved. Pkt. 5c, oz. 35c, I/4 lb. $\$ 1.00$, lb. $\$ 3.50$.

FLORIDA HIGH BUSH. A very popular sort with Southern truckers, growing 3 to 4 feet high, with very strong, vigorous, upright vines, and holding its fruit well up above the ground. The Egg Plants are dark rich purple in color, of large size, fine quality, and one of the best keeping. Pkt. 5c, oz. $40 \mathrm{c}$, $\mathrm{r} / 4$ lb. $\$ 1.25, \mathrm{lb} . \$ 4.00$.

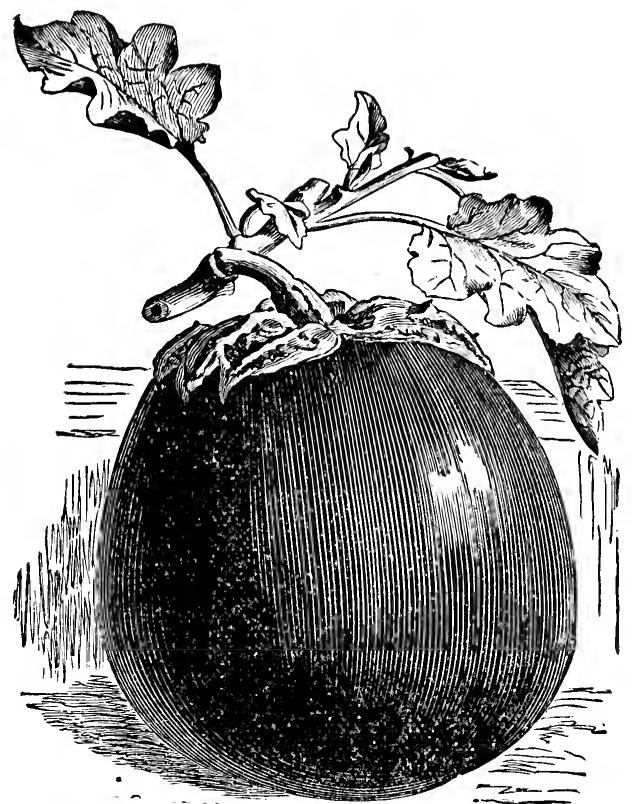

New York Improved Purple Egg Plant

HORSE RADISH Horse Radish produces no seed, but is grown from pieces of the roots. Culture.-Mark off the rows two and one-half feet apart in rich, moist, well-prepared ground, and set the pieces of roots eighteen inches apart in the rows, vertically, the small end down, and the top one to three inches below the surface. Cultivate thoroughly until the tops cover the ground, when their shade will keep down the weeds.

Small roots, 3 for $10 c ; 25 c$ per dozen, postpaid. By freight or express, buyer to pay charges; doz. $15 \mathrm{c}$, per $10060 \mathrm{c}$, per $1,000 \$ 5.00$.

\section{KALE OR BORECOLE}

Culture.-Sow either broadcast or in drills eighteen inches apart, from first of September till the middle of October. It may also be sown in February or March, at which time the Smooth or Spring Kale is best. Of late years the latter has been largely sown in the fall, making greens earlier than the winter sorts. Protect with straw or coarse litter in severe weather, as it can be cut during the winter and spring. Sow winter sorts at the rate of three or four pounds to the acre. Spring Kale can be sown broadcast at the rate of eight pounds to the acre, or four or five pounds in drills.

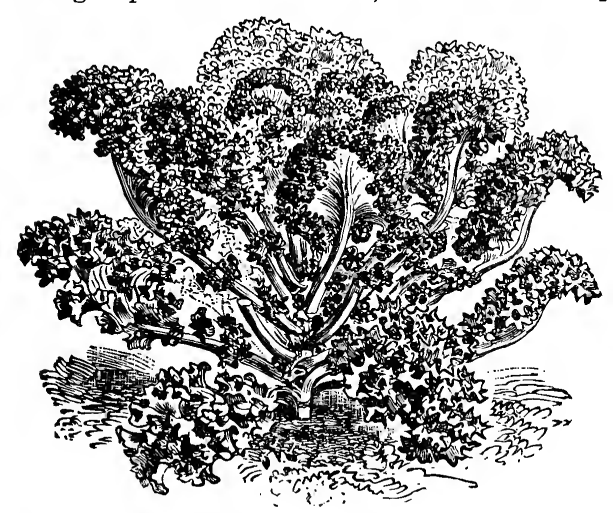

Green Curled Siberian Kale

DWARF GREEN CURLED SCOTCH, OR NORFOLK. One of the most popular shipping sorts; very largely used in the Norfolk trucking district. The leaves are of a bright green color, beautifully curled. Should be sown in rows or broadcast in August and September. Pkt. 5c, oz. $7 \mathrm{c}, \mathrm{r} / 4 \mathrm{lb}$. $15 \mathrm{c}, \mathrm{lb}$. $50 \mathrm{c}$.

Spring, or Smooth Kale. A hardy, quick-growing, smooth-leaved variety, which makes a fine salad. Very hardy, and is largely grown in September for use during the winter and spring months. The best for sowing in the spring. Large pkt. $5 c, 1 b .15 c, 2$ lbs. 25 c, 10 lbs. at 10 c per $1 \mathrm{~b}$. ostage.
For Bulk Seed by Mail, add 2c for $4 \mathrm{oz}$; $8 \mathrm{c}$ per lb. for ple, and beautifully curled and delicate in flavor. In the latitude of Louisville it will stand throughout the winter without protection. Oz. 5c, I/4 lb. $15 \mathrm{c}, 1 \mathrm{~b} .40 \mathrm{c}$. Green Curled Siberian which produces leaves not quite so curled as the Northern grown offered above. $\mathrm{Oz}$. $5 \mathrm{c}, \mathrm{I} / 4$ lb. $10 \mathrm{c}, 1 \mathrm{~b} .25 \mathrm{c}$.

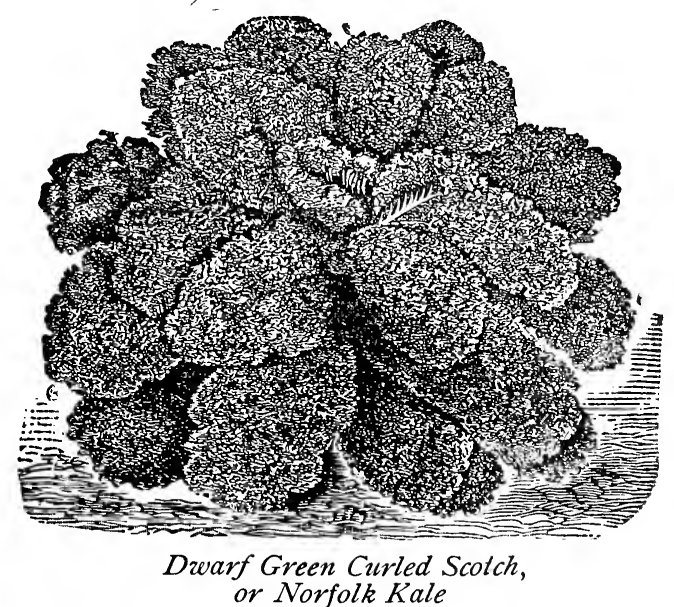




\section{KOHL RABI}

A vegetable intermediate between the Cabbage and Turnip, which combines the flavor of both. It

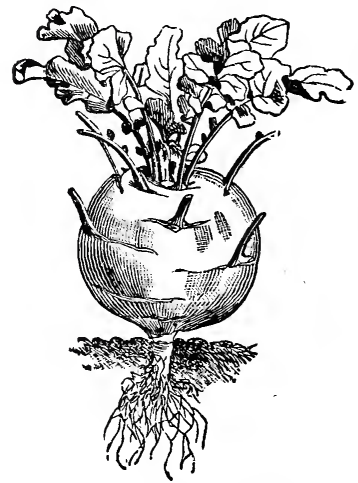

Early White Vienna Kohl Rabi forms a turnip-shaped bulb above the ground, which is prepared for the table like turnips. If used when young and tender, makes a delicate and desirable vegetable.

Culture.-For early use sow in hot beds or in the open ground in March or April, in rows eighteen inches apart. Thin out or transplant like cabbage. Can also be sown in June or July for fall. One ounce will sow 200 feet of drill.

Early White Vienna. Splendid sort for general use, having white, tender flesh, and making good-sized bulbs. Hkt. 5:, oz. $20 \mathrm{c}, \mathrm{r} / 4$ 1b. $60 \mathrm{c}, 1 \mathrm{~b} . \$ 2.00$.

LEEK The Leek is generally considsoup flavoring, etc. ered superior to the onion for

Culture.-Sow as early as practicable in the spring in a light, rich moist soil in drills half an inch deep. When six or eight inches high trim off the tops and roots and transplant to rows one foot apart and six inches apart in the row, setting them three to four inches deep and earthing up as they grow, so that the necks will become well blanched. The seed may also be sown in September, and the young plants transplanted in the fall or early in the spring to where they are to remain. One ounce will sow

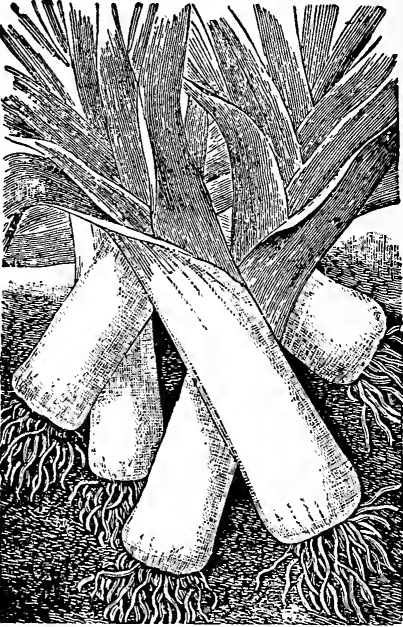

Leek about one hundred feet of drill.

LARGE FLAG. Very large and popular variety. Perfectly hardy. Pkt. 5c, oz. 15c, I/4 1b. 40c, 1b. \$1.25.

GIANT MUSSELBURGH. Enormous size, leaves large and broad, mild and pleasant flavor. Pkt. 5c, oz. 15 c, $1 / 4$ lb. 50 c, lb. $\$ 1.50$.

\section{LETTUCE}

One ounce sows 300 feet of drill; 3 lbs. to one acre. One ounce produces 2,500 plants. An acre in set plants requires about 65,340 set $6 \times 16$ in.

Culture.-For winter forcing make sowings from September to February. Sow the curled varieties about every four weeks, the Head or Cabbage sorts about six weeks apart. As one crop is cut out another can be planted. For early spring crop sow under glass in January or February, and transplant in the spring For succession sow at intervals of three weeks until end of April. For autumn use sow in July. For fall planting sow the hardy varieties in September and transplant, when large enough, to cold frames nine inches a part.

Packets of all varieties 5c each; 6 for 25c. Pkts. and ounces mailed free. Bulk seed by mail, add $8 \mathrm{c}$ per lb. for postage.

\section{Curled or Loose Head Varieties}

\section{BLACK SEEDED SIMPSON. (White Paper}

Lettuce.) A very popular sort among market gardeners. Forms a large, loose head; its nearly white curly leaves thin, exceedingly tender, and of good quality. Splendid for growing under glass and early planting outside. Pkt. $5 \mathrm{c}$, oz. $15 \mathrm{c} ; \mathrm{r} / 4 \mathrm{lb}$ $35 \mathrm{c}, \mathrm{lb}$. $\$ 1.00$.

TILTON'S WHITE STAR. A splendid sort either for forcing or outdoors. Bright color, crisp, long keeper, and superior to B. S. Simpson for greenhouses not having full sunlight. Pkt. $5 \mathrm{c}$, oz. $15 \mathrm{c}, \mathrm{t} / 4 \mathrm{lb} .35 \mathrm{c}$, lb. $\$ 1.00$.

GRAND RAPIDS. This variety is especially adapted to greenhouses or forcing, in frames, and is generally recognized as the standard of forcing lettuce. The plant is upright, forms a loose head of large green leaves, crimpled at the edges, not liable to rot, and stands some days after ready to cut. Splendid for market, shipping, or family use, either indoors or outside. Pkt. $5 \mathrm{c}$, oz. $15 \mathrm{c}, \mathrm{t} / 4 \mathrm{lb} .35 \mathrm{c}, 1 \mathrm{~b} . \$ 1.00$.

EARLY CURLED SIMPSON. White seeded. Makes a curled, loose head; early and tender. Pkt. $5 \mathrm{c}$, oz. $15 \mathrm{c}, \mathrm{I} / 4$ lb. $35 \mathrm{c}, 1 \mathrm{~b} . \$ 1.00$.

DENVER MARKET. An early variety, making large, solid heads; leaves crimped like Savoy Cabbage; very crisp and tender, and desirable either for home or market use. Pkt. $5 \mathrm{c}, \mathrm{oz}$. 15c, $\mathrm{x} / 4$ ib. $35 \mathrm{c}, 1 \mathrm{~b} . \$ 1.00$. 


\section{LETTUCE-Continued}

\section{Heading or Cabbage Varieties}

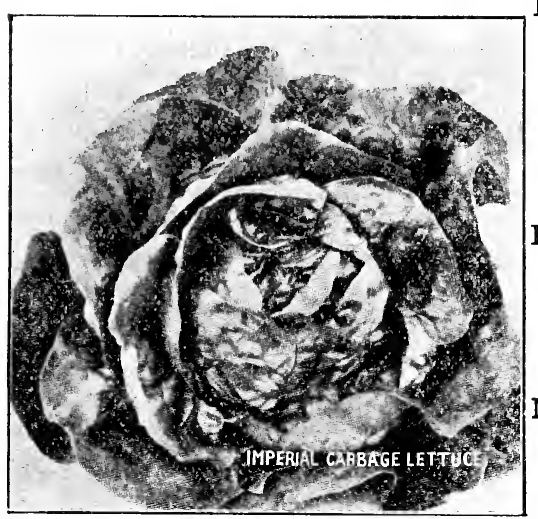

IMPERIAL CABBAGE. Gardeners who have grown this lettuce say there is no better heading sort for main-crop spring planting. The heads of light green color outside, with yellowish white heart, are large, solid, and of finest quality, and very tender. It is slow in running to seed, grows quickly, is an even, reliable header, and will be found thoroughly satisfactory, both for outside planting and in frames. Pkt. 5 c, oz. 20 c, $1 / 4$ lb. 60 c, 1 b. $\$ 2.00$.

BIG BOSTON. One of the most popular of all for forcing or spring crop outside, and more largely used for market generally than any other sort. Heads are large, very crisp and solid, of light green color, and uniformly reliable heading. Extra selected stock. Pkt. 5c, oz. $15 \mathrm{c}, 1 / 41 \mathrm{~b} .40 \mathrm{c}$, 1b. $\$ 1.25$.

MAY KING. Of quick growth and produces large, handsome heads with few outside leaves. Color light green, outer leaves folding closely, producing round, solid heads six to seven inches in diameter. Splendid for market gardeners or private use. Pkt. 5c, oz. $15 \mathrm{c}, \mathrm{I} / 4$ lb. 35c, 1b. $\$ 1.00$.

CALIFORNIA CREAM BUTTER. In shape this is distinct, heading up like a cabbage, almost as solid. The color is light green, almost white; the flavor rich and buttery, and very tender. Specially recommended for spring and summer use. Pkt. 5c, oz. $15 \mathrm{c}, \mathrm{r} / 4$ lb. $35 \mathrm{c}, 1 \mathrm{~b} . \$ 1.00$.

DEACON CABBAGE. Medium-sized head, very light green. Solid, crisp, and one of the best table sorts for summer. Pkt. 5c, oz. $15 \mathrm{c}, \mathrm{t} / 4$ lb. $35 \mathrm{c}, 1 \mathrm{~b} . \$ 1.00$.

ICEBERG. A reliable heading sort, with crisp, tender, indented leaves, which when wet with dew, gives a crystalline appearance. Very satisfactory. Pkt. 5c, oz. 15c, I/4 lb. 35c, 1b. $\$ 1.00$.
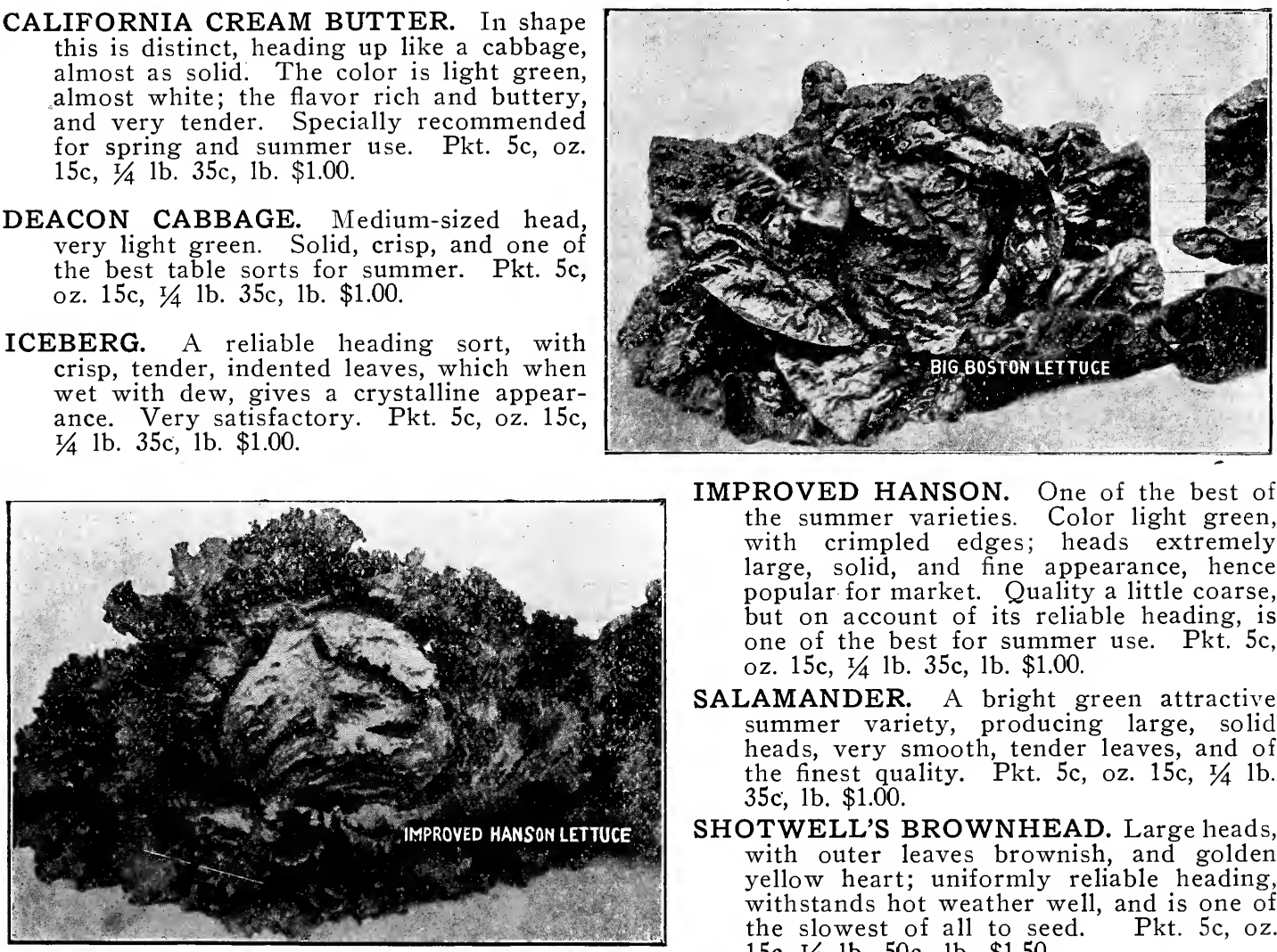

IMPROVED HANSON. One of the best of the summer varieties. Color light green, with crimpled edges; heads extremely large, solid, and fine appearance, hence popular for market. Quality a little coarse, but on account of its reliable heading, is one of the best for summer use. Pkt. $5 \mathrm{c}$, oz. $15 \mathrm{c}, \mathrm{r} / 4$ lb. $35 \mathrm{c}, 1 \mathrm{~b}$. $\$ 1.00$.

SALAMANDER. A bright green attractive summer variety, producing large, solid heads, very smooth, tender leaves, and of the finest quality. Pkt. 5c, oz. $15 \mathrm{c}, \mathrm{I} / 4 \mathrm{lb}$. 35c, 1b. $\$ 1.00$.

SHOTWELL'S BROWNHEAD. Large heads, with outer leaves brownish, and golden yellow heart; uniformly reliable heading, withstands hot weather well, and is one of the slowest of all to seed. Pkt. 5c, oz. $15 \mathrm{c}, \mathrm{x} / 4$ lb. $50 \mathrm{c}, 1 \mathrm{~b}$. $\$ 1.50$.

TRIANON COS. The Romaine Lettuce of the French. Leaves upright, very crisp, and in great favor with many people. Pkt. $5 \mathrm{c}$, oz. $15 \mathrm{c}, \mathrm{I} / 4 \mathrm{lb}$. $35 \mathrm{c}, 1 \mathrm{~b} . \$ 1.00$.

Boșton Market. Small, compact heads, fine for forcing. Pkt. 5c, oz. 15c, I/4 1b. 35c, 1b. $\$ 1.00$.

Henderson's New York. The largest heading sort grown for outside; light green leaves, somewhat coarse. Pkt. 5c, oz. $15 \mathrm{c}, \mathrm{t} / 4$ 1b. $35 \mathrm{c}, 1 \mathrm{~b}$. $\$ 1.00$.

LETTUCE PLANTS supplied in season. Varieties: Black Seeded Simpson, Big Boston, and California Cream Butter. Per $10030 \mathrm{c}, 1000 \$ 2.50$. Special prices in large lots. No plants sent by mail. 


\section{Crops Very Short}

One ounce plants 50 hills; 2 lbs. to the acre. Plant in May for early crop, and in June for late.

Culture.- Prepare hills four to six feet apart; a rich, moderately dry, sandy soil or sod land is best, asing well rotted stable manure or Acme Brand B. B. B. Fertilizer, which should be well mixed with the soil. When danger of frost is past, plant ten or twelve seeds about an inch deep in each hill, and is excellent to sprinkle over the young plants when the dew is on, to prevent the attacks of insects; to promote fruitfulness, pinch the ends of the vines when they begin to blossom, especially if the growth is very luxuriant, and cultivate until the vines cover the ground.

Insect Remedies. - The yellowish green and spotted melon bug is the principal enemy to the melons, not only eating the leaves of the vines, but also eating holes in the melons. The liberal use of Tobacco Dust in and upon the hills and vines is one of the best remedies for this and other insects that prey upon the melons and melon vines.

Packets of Cantaloupes are $5 \mathrm{c} ; 6$ for $25 \mathrm{c}$. Seeds in pkts., ounces, and I/4 1bs., mailed free. To pound prices add $8 \mathrm{c}$ if to be mailed.

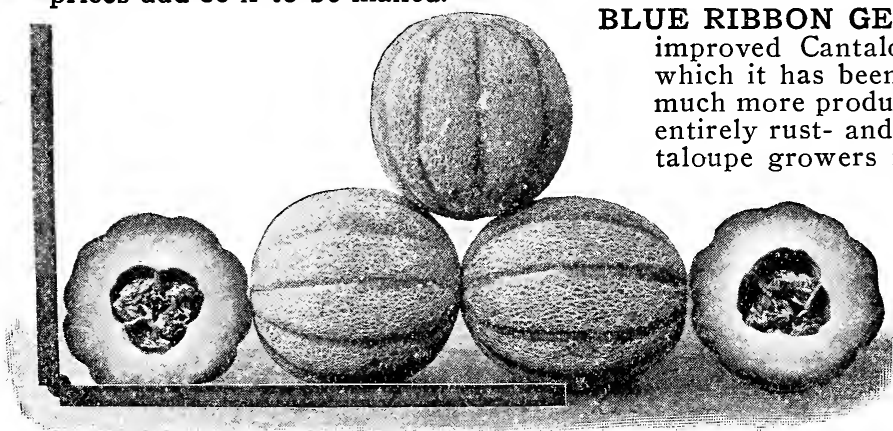

Blue Ribbon Gem Cantaloupe

UE RIBBON GEM. A distinctly new and very much improved Cantaloupe of the Rocky Ford type, from which it has been bred. It is two weeks earlier, very much more productive, a little more netted, and almost entirely rust- and blight-proof. Most of the best Cantaloupe growers in this locality planted this sort last year, and we have yet to hear one of them who was not thoroughly pleased, and some of them are enthusiastic in its praises as a moneymaker.

Blue Ribbon Gem retains all of the characteristic sweetness of its parents, grows a trifle larger in size, and is so much superior in growth, productiveness, earliness, depth of meat, and appearance, that it will become the most important of the Netted Gem type. Pkt. 5c, oz. $10 \mathrm{c}, 1 / 4$ lb. $35 \mathrm{c}, 1 \mathrm{~b} . \$ 1.00,5 \mathrm{lbs}$. and over, $95 \mathrm{c}$ per $1 \mathrm{~b}$.

The following testimonials express generally what the leading growers of Jefferson County, Ky., think of Blue Ribbon Gem Cantaloupes:

"I used a considerable quantity of Blue Ribbon Gem Cantaloupe this year, and consider it the best sort on the market. It is the same type as Rocky Ford, only larger, ten days to two weeks earlier, and thoroughly satisfactory. I expect to use considerable quantities of it in future."-Wm. Payne.

"I heartily endorse your claim for Blue Ribbon Gem Cantaloupe. It is a most superior market sort, coming in earlier than Rocky Ford, a little larger in size, splendidly netted, and a fine eating and market variety."-Henry H. Fey.

"Blue Ribbon Gem Cantaloupes are superior to Rocky Ford in earliness, yield, and about one-third larger in size. They are good sellers, fine quality, and proved with me to be one of the best eating sorts I have planted."-D. Huflage.

WOOD'S PERFECTION. One of the best of large Cantaloupes, whether wanted for shipping, the near-by market, or home use. Gardeners using this variety speak in highest terms of its sterling qualities, and wherever tried it is the most popular of all for main crop, where good-sized melons are wanted. The flesh is thick, of a beautiful deep rich green color, tinted with salmon; unusually sweet and luscious. The melons average about one-half again larger than Rocky Ford, very netted, and distinctly marked ribs. Pkt. 5c, oz. 10c, I/4 1b. 35c, 1b. $\$ 1.25$.

ROCKY FORD. This famous melon is well known everywhere, and has been the standard shipping variety. The melons are really the true Netted Gem type, medium sized, oval, and very sweet and fine flavored. Very prolific, and continue bearing enormous quantities of fruit during the entire season. Fine stock. Pkt. $5 \mathrm{c}$, oz. $10 \mathrm{c}, \mathrm{I} / 4$ lb. $25 \mathrm{c}, 1 \mathrm{~b} .75 \mathrm{c}, 5 \mathrm{lbs}$. and over, $70 \mathrm{c}$ per $1 \mathrm{~b}$.

NETTED GEM. Introduced twentyfour years ago, and still retains its great popularity in all sections. The fruits are of medium size, oblong, ribbed, and netted, very firm and solid, will bear handling remarkably well. Vines vigorous, very prolific in fruit, and almost all of them can be relied upon to be sweet and highly flavored. Our stock of this is from selected melons. Pkt. 5c; oz. 10 c, $1 / 4$ lb. 25 c, lb. 75 c, 5 lbs. and over, $70 \mathrm{c}$ per $1 \mathrm{~b}$.

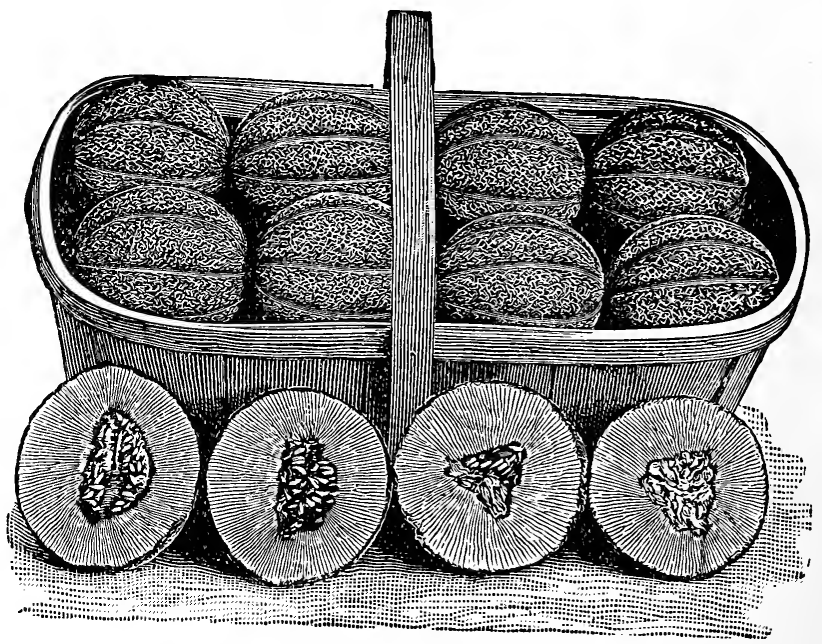

Rocky Ford Cantaloupe 


\section{CANTALOUPE-Continued}

TIP TOP. Fruits grow to a good size, slightly oval, flesh sweet and juicy, of an orange color and firm. A splendid market sort, and one that will please for family use, especially on rich soil. Pkt. $5 \mathrm{c}$, oz. $15 \mathrm{c}, \mathrm{1} / 4 \mathrm{lb}$. $50 \mathrm{c}, 1 \mathrm{~b}$. $\$ 1.50$.

LONG ISLAND BEAUTY. Melons of large size, well flattened and heavily ribbed and netted. A very handsome appearance, green, and very deep flesh of fine quality. This variety ripens as early and resembles the Hackensack, but is superior and one of the leading market varieties. Pkt. 5c, oz. $10 \mathrm{c}, 1 / 4$ lb. $35 \mathrm{c}, 1 \mathrm{~b} . \$ 1.25$.

CHAMPION MARKET. An oval-shaped, medium-sized melon, which is highly prized by many growers for market. It is medium early, thickly netted, flesh light green and good quality. Pkt. 5c, oz. 10c, $\mathrm{I} / \mathrm{l}$ lb. $30 \mathrm{c}, 1 \mathrm{~b} . \$ 1.00$.

PAUL ROSE. A cross of Osage with Netted Gem. Medium size, oval, very deep salmon flesh, sweet and luscious. Splendid. Pkt. $5 \mathrm{c}$, Oz. $10 \mathrm{c}, \mathrm{t} / 4 \mathrm{lb}$. 30c, $1 \mathrm{~b} . \$ 1.00$.

EXTRA EARLY HANOVER. The earliest of all cantaloupes, and on this account highly recommended for early market. It is

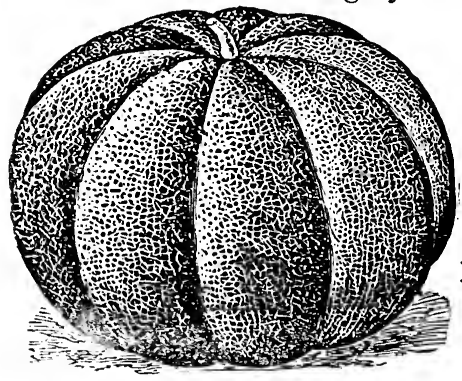

Extra Early Hanover Cantaloupe of medium size, round, and flattened at the ends, ribbed and well netted. The flesh is fairly good quality; its main value, however, is its extreme earliness, and for this reason it is one of the most profitable sorts which can be planted. Pkt. 5c, oz. 10c, $1 / 4$ lb. 35c, lb. $\$ 1.25$.

EXTRA EARLY HACKENSACK. Ten days earlier than Large Hackensack. Roughly netted skin, flattish shape, good quality. Pkt. 5c, oz. $10 \mathrm{c}, 1 / 4$ lb. $30 \mathrm{c}$, lb. $\$ 1.00$.

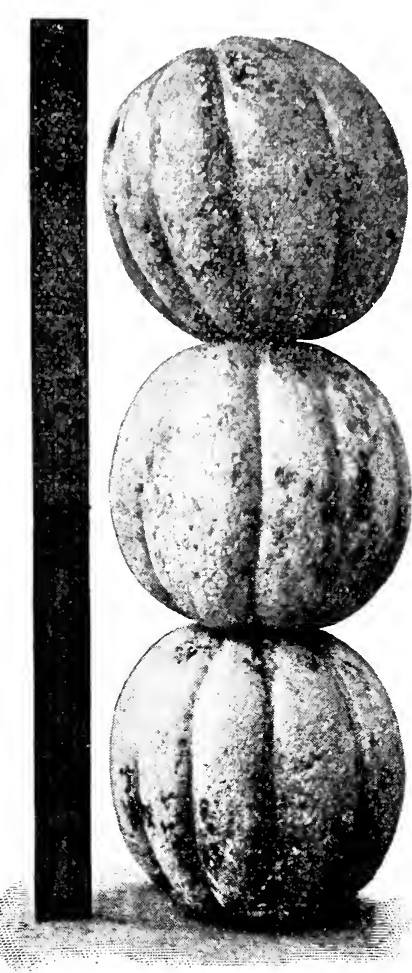

Tip Top Cantaloupe

Osage, or Miller's Cream. Medium size, round shape, salmon colored, very thick flesh, with smooth, grayish skin.-.

EMERALD GEM. Medium size, oval, smooth, green rind, thick salmon flesh, very sweet and fine flavored

Large Hackensack, or Turk's Cap. A popular large sort, heavily netted and ribbed, greenish flesh.-

Baltimore, or Acme. Oblong shape, twice as large as Rocky Ford, well netted and ribbed. Deep, sweet, greenish flesh

Jenny Lind. Extra early, small size, flat, good quality; prolific -

Banana. Long, smooth, yellow-skinned; salmon flesh
Glass Melon. Small fruits about the size of an orange. Skin greenish yellow. Fine for preserves, pickles, sweetmeats. Very prolific_._-_.- 5

$\begin{array}{rrrrrr}5 & 10 & 30 & & 85 & 80 \\ 5 & 15 & 50 & 1 & 50 & -- \\ 5 & 10 & 30 & 85 & 80 \\ 5 & 10 & 30 & 100 & - \\ 5 & 10 & 30 & 90 & 85 \\ 5 & 15 & 50 & 175 & -- \\ 5 & 15 & 50 & 175 & --\end{array}$

\section{WATERMELONS}

One ounce plants 30 hills; 3 lbs. to the acre. Plant early in May, or for late use, in June.

Culture.-Cultivate exactly like cantaloupes, giving more room, say ten or twelve feet apart, each way. Insect Remedies.-See under Cantaloupes.

Packets, ounces and $1 / 4$ lbs. mailed at prices. In Bulk by Mail, add 8 cents per lb.

TEMPLE GRAY. One of the best melons, either for market or home use. Attains a larger size than any of the long, dark green melons, frequently growing fifty pounds in weight. Will stand shipping fairly well, is of extra fine appearance and unsurpassed quality. Flesh tender, firm, and very sweet and luscious. White seeds tipped with black. We obtained it in Tennessee, where it is the most popular with all growers when once planted. Pkt. 5c, oz. 10 c, $1 / 4$ lb. 85 c, lb. $\$ 1.25$.

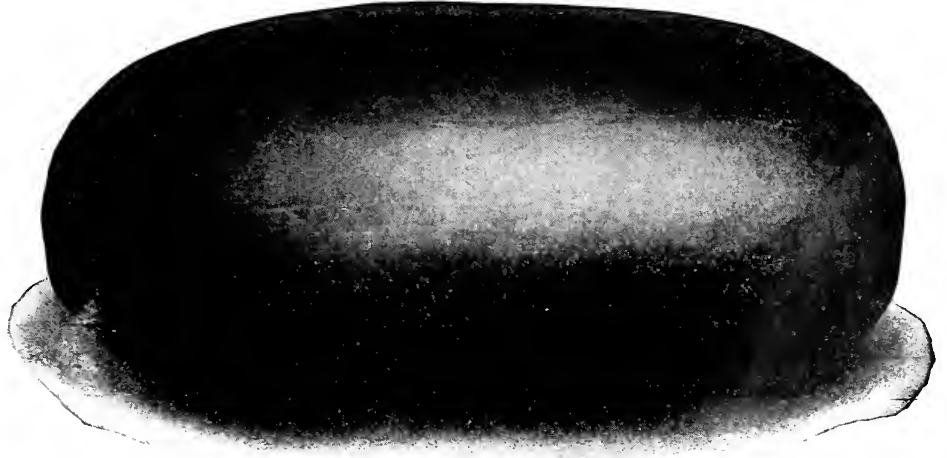

Temple Gray Watermelon 


\section{WATERMELONS-Continued}

HARRIS' EARLIEST. One of the best early sorts for shipping or market. The melons are oval or oblong, beautifully striped with dark green and gray. Flesh bright red, sweet, crisp, and delicious. Harris' Earliest is a very productive variety, and so extremely early that good melons can be picked the first of July in this latitude. The size averages twenty to thirty pounds. Pkt. 5c, oz. 10 c, $1 / 4$ lb. 20 c, 1b. 70 c, 5 lbs. at 65 c per $1 b$.

SWEET HEART. A new shipping melon of large size and fine quality: The vines are very vigorous and productive, bearing the fruit early. Melons uniform in size, oval-shaped, and very heavy. The rind is light green, thin, but firm; flesh bright crimson, sweet and tender. Particularly fine for shipping or market for main crop, being of such fine appearance that they sell readily. Pkt. $5 \mathrm{c}, \mathrm{oz}$. $10 \mathrm{c}, \mathrm{I} / 4 \mathrm{lb} .20 \mathrm{c}, 1 \mathrm{~b} .50 \mathrm{c}$.

MCIVER'S WONDERFUL SUGAR MELON. A variety of recent introduction, which is of good shape and color, sweet, productive, and very satisfactory for home use or market. Melons often attain great weight, are of very handsome appearance, never crack or lose their fine flavor in a wet season. The color is light green, shaded with darker stripes. Pkt. 5c, oz. 10c, 1/4 1b. 20c, lb. $60 \mathrm{c}, 5$ ibs. at $55 \mathrm{c}$ per $1 \mathrm{~b}$.

HALBERT'S HONEY. Of splendid quality, and especially desirable for home use or near-by market. Has a dark green, very thin rind, exceedingly attractive, meat so crisp and tender that wellripened melons split ahead of the knife in cutting. Melons are long, blunt at both ends, and vines very productive. Pkt. 5c, oz. $10 \mathrm{c}, \mathrm{I} / 4 \mathrm{lb} .25 \mathrm{c}, 1 \mathrm{~b} .75 \mathrm{c}$.

KLECKLEY SWEETS. This is one of the best flavored melons in cultivation, and of a shape and color that is extremely desirable. The rind is very dark green, very thin, flesh deep scarlet, fine, and of delicious quality. For the home market and family garden it is decidedly one of the best. Pkt. 5c, oz. 10c, I/4 lb. 25c, 1b. 75 c, 5 lbs. at 70 c per $1 b$.

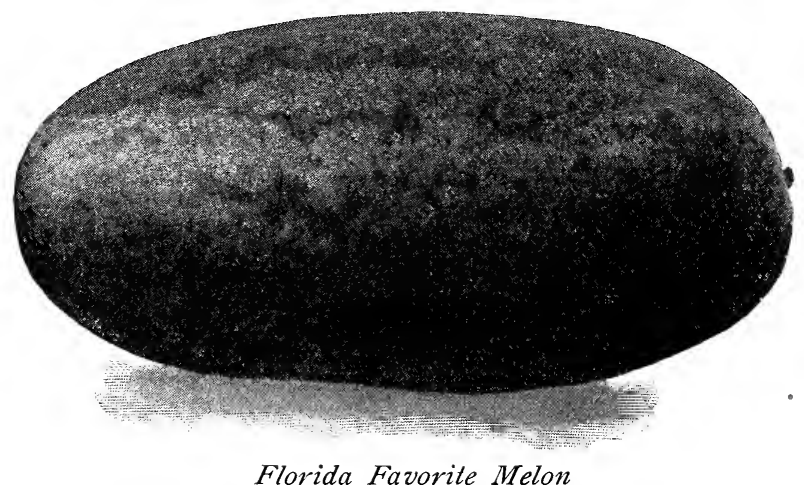

Florida Favorite Melon

FLORIDA FAVORITE. This has long been a prime favorite for home consumption, for which purpose it is regarded by many as the finest melon grown. Ripens early, has dark skin with light green stripes and light crimson flesh; exceedingly sugary, and so delicious and melting that one feels perfectly satisfied when eating Florida Favorite. Pkt. 5c, oz. $10 \mathrm{c}, 1 / 4$ lb. $20 \mathrm{c}$, lb. $60 \mathrm{c}, 5 \mathrm{lbs}$. and over at $55 \mathrm{c}$ per $1 \mathrm{~b}$.

GEORGIA RATTLESNAKE. Melons are long in shape, of light green color, with dark stripes, and grow of uniformly large size and symmetrical shape. In Georgia this variety is one of the most highly prized of all. The rind is remarkably thin, though it stands shipping well, and the flesh most tender, sweet, and luscious, it being a rare thing to find a melon that is not of superior quality. A satisfactory one to grow for all purposes. Pkt. 5c, oz. $10 \mathrm{c}, \mathrm{r} / 4 \mathrm{lb}$. 20c, 1b. $60 \mathrm{c}, 5 \mathrm{lbs}$. and over $55 \mathrm{c}$ per $1 \mathrm{~b}$.

KOLB'S GEM. The famous shipping short. Oval, dark mottled green, very tough rind, solid flesh; large and attractive, but not of fine quality $5 \quad 10 \quad 15 \quad 45 \quad 40$

Peerless. Fruit medium-sized and oblong in shape, dark green rind; flesh bright scarlet, solid, crisp, tender, and of the highest flavor. Vines moderately vigorous, hardy, and productive

Dark Icing, or Ice Cream. Round, medium size; skin dark green, flesh bright red, exceedingly tender and delicious. Fine for early home use or near-by market_-_-

Triumph. Similar to Kolb's Gem, except darker green, and attains larger size. Splendid for shipping or growing for prizes, where size counts --

DUKE JONES. Extra early, very large, round sort, with darkest green rind. Good for market or shipping

Jordan's Gray Monarch. Light green, oblong, large size, and good quality. In high favor for home use, shipping, and market

Citron. For preserving Pkt. Oz. $\quad \mathrm{r} / 4$ lb. 1 lb. 5 lbs.

$\begin{array}{lllll}5 & 10 & 15 & 45 & 40 \\ 5 & 10 & 15 & 55 & 50 \\ 5 & 10 & 15 & 55 & 50 \\ 5 & 10 & 15 & 55 & 50 \\ 5 & 10 & 15 & 45 & 40 \\ 5 & 10 & 15 & 50 & 45 \\ 5 & 10 & 20 & 55 & 50\end{array}$

Large Buyers. We will quote special prices of Melon Seeds on request. Send us list of your requirements. 
MUSHROOM SPAWN Mushrooms can be grown in cellars, sheds, or under benches

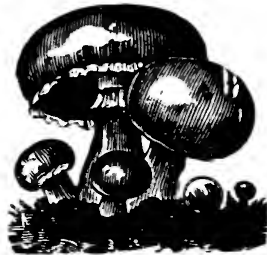

Mushrooms open air. The crop has proved very profitable in this locality, and we advise large planting, as mushrooms have proved very profitable in this as well as in other markets. Our cultural instructions on Mushrooms are necessarily limited for want of space, but we can furnish books on the subject, one of the best being "Mushrooms and How to Grow Them," by Wm. Falconer, mailed for $\$ 1.00$.

Culture.-Use fermenting horse manure at a temperature of 70 degrees, mix with equal weight of fresh, sod loam. The beds can be made of the size required, and should be about 8 inches deep, packed well and packed evenly. In these beds plant the broken pieces of spawn about 1 to $1 \frac{1}{2}$ inches in diameter, 6 inches apart, and cover with 2 inches of light soil. A brick usually weighs about $11 / 4$ lbs., and plants 8 or 10 square feet. Water should be given sparingly, and should be lukewarm. Mushrooms will appear in about six weeks.

English Mushroom Spawn, per 1b. 20c, $5 \mathrm{lbs}$. and over, 15c per lb; postage 10c per lb. extra; case of 100 lbs. at 9c per $1 b$.

\section{MUSTARD}

One ounce sows 30 feet, 4 or 5 lbs. per acre.

This is grown to quite a large extent in the Southern States. It is used the same as Spinach or boiled with meat as greens. The white or yellow-seeded variety is cultivated chiefly for medicinal purposes or pickling.

Culture.-Sow during February, March, or April, or in the fall during September or October, either broadcast or in rows six inches apart. Cut when about three inches high. Sow one ounce to eighty feet of drill, or broadcast at the rate of five or six pounds per acre.

Southern Giant Curled. An improved variety, much esteemed in the South. Very succulent, pungent, and of sweet flavor. Pkt. 5c, oz. 10c, $1 / 4$ 1b. 25c, 1b. $75 \mathrm{c}$.

White. Used for salad. Oz. $5 \mathrm{c}, \mathrm{r} / 4 \mathrm{lb}, 10 \mathrm{c}, 1 \mathrm{~b} .25 \mathrm{c}$.

Black. Oz. 5c, 1/4 1b. 10c, 1b. 25c.

Mustard Seed for Pickles. Lb. $15 \mathrm{c}$

\section{OKRA OR GUMBO}

One ounce sows 40 feet of drill, 15 lbs. per acre. Plant in April or May. Matures in sixty or se venty days from planting.

This vegetable should be more generally grown, as it adds consistency, and makes a fine flavoring for soups, stews, and gravies. Also gives a good flavor to canned tomatoes.

Culture.- When the ground has become warm, sow thickly in drills three feet apart, and when large enough thin out to eight inches apart in the rows. To keep for winter use slice the pods when young and tender into narrow rings; string and hang in the shade to dry.

WHITE VELVET. This variety bears round, white, smooth pods, unlike other varieties, which are ridged or square-edged. The pods are of extra large size, and are produced in great abundance. Pkt. 5c, oz. 10c, $1 / 4$ lb. 15c, lb. 50c.

Improved Dwarf Prolific, or Density. An excellent prolific sort. Pkt. 5c, oz. 10c, I/4 lb. 15c, 1b. 40c.

Tall. Produces dark green ridged pods. Pkt. 5c, oz. 10c, I/4 lb. 15c, lb. 40c.

\section{ONION}

Sow in March or April out doors. For large Onions at the rate of 5 to $6 \mathrm{lbs}$. per acre. For sets 40 to $60 \mathrm{lbs}$. per acre. For Pickle Onions, $1 \mathrm{oz}$. sows 150 feet. 15 lbs. per acre.

Calture.-For large, fancy onions: Sow in January or February in hot beds or trays. As soon as the weather opens and the sets are the size of a goosequill, transplant in rows twelve inches apart and four to six inches between the onions. For Main Crop: Sow in the open ground in March or April in drills twelve inches apart, thinning out afterwards to three or four inches apart. For Sets: Sow in February or March in rows ten to twelve inches apart in smooth, clean, wellprepared land. Keep free of all weeds and cultivate as prepared land. Keep free of all weeds and cultivate as to produce small-sized sets.

LARGE GROWERS OF ONION SETS are requested to ask for special prices on Onion Seed. Prices very unsettled.

The seed of the first two sorts have been grown in this locality, and are the principal ones used here. SILVER SKIN. Excellent variety for family use. Skin and flesh pure white; mild flavor and flattish shape. The best white onion to grow largely for sets. Pkt. 5c, oz. 15c, 1/4 1b. 35c, 1b. \$1:25.

YELLOW DANVERS. Standard variety; flat-shaped, large in size. One of the principal main-crop sorts for sets or large onions. Keeps well and is a most desirable market or table onion. Pkt. 5 c, oz. $10 \mathrm{c}, 1 / 4$ lb. 20 c, $1 \mathrm{~b} .60 \mathrm{c}$. 


\section{ONION-Continued}

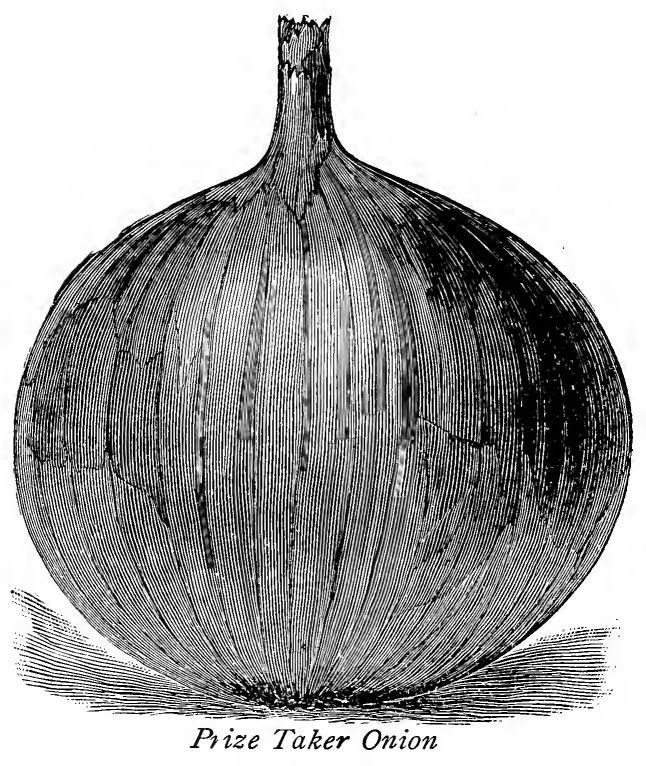

Red Wethersfield. A quick-growing, dark red sort, desirable for sets or large onions. Uniform in size, shape, close-grained, of mild flavor. Pkt. 5c, oz. 20 c, $1 / 4$ lb. 60 c, 1b. $\$ 2.00$.

Extra Early White Pearl. The quickest growing of all the white sorts; makes large, pearly white onions, tender, mild, and of excellent flavor. The seed should be sown in the spring thickly and the sets put out in the fall. In this way large onions may be had before any other sorts are ready. Pkt. 5c, oz. 20 c, $1 / 4$ lb. 60 c, 1b. $\$ 2.00$.

PRIZE TAKER, or SPANISH KING. Like nearly all Spanish Onions, this makes extra large size onions, and of particularly fine flavor. The outside skin is a rich yellow straw color, and the flesh is pure white, sweet, mild, and tender. It ripens up fine and hard and makes a very handsome and attractive onion. Pkt. 5c, oz. 20c, $1 / 4$ lb. 50c, 1b. $\$ 1.75$.

MAMMOTH SILVER KING. This is one of the largest onions in cultivation, growing to a remarkable size. The skin is a beautiful silver white, flesh pure white, and of a particularly mild and pleasant flavor. It matures early and grows uniformly of large size and perfect form, flattened at the top. Specially recommended both for fall and spring planting. Pkt. 5c, oz. 20c, I/4 1b. 50c, 1b. $\$ 1.75$.

\section{ONION SETS}

\section{Prices subject to Market Changes.}

This is one of the largest markets on onion sets in the world, and Louisville sets are shipped to all parts of the United States. Large buyers can get the very lowest market prices from us.

If it be sent by mail add 10 cents per quart for postage.

Culture.-Plant the sets four inches apart in rows about half an inch deep and one foot between the rows, but do not cover the sets entirely. This applies to all varieties except the Potato Onion, which should be planted in rows fifteen inches apart and nine inches apart in the row, and then covered with about one inch of soil. All varieties can be set out in the fall as well as in the spring. Fall planting of onions are succeeding very well in the South, and should be more generally practiced.

Yellow Danvers. The well-known variety used so largely in this section for dry onions. Pickle onions of this sort, planted in the fall, make excellent bunching onions for spring use. Qt. $15 \mathrm{c}, 2$ qts. for $25 \mathrm{c}, \mathrm{pk}$. $75 \mathrm{c}$, bushel prices on application.

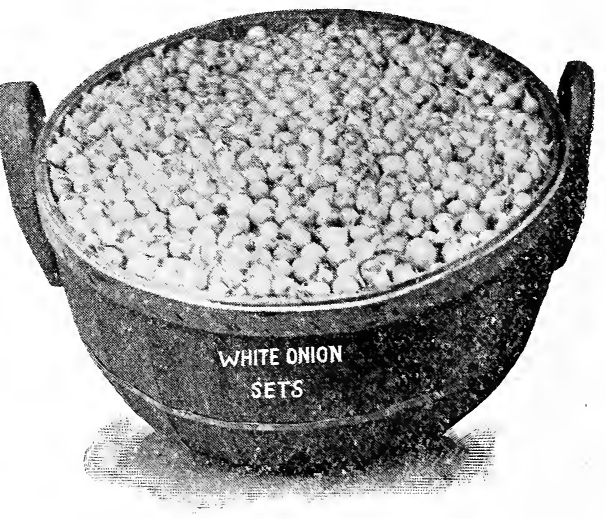

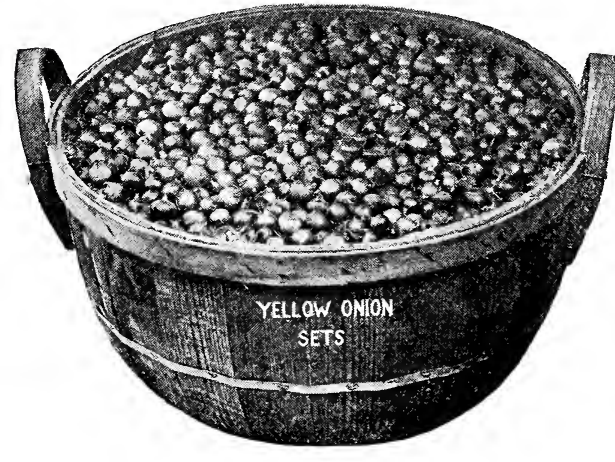

Silver Skin. Pure white, of mild flavor, and usually preferred for private uses, both for cooking and pickling. Qt. 15c, pk. $\$ 1.00$, bushel prices on application.

Yellow Potato. A mild yellow sort growing in clumps, producing no seed. Stock scarce; ask for prices.

GARLIC A bulbous-rooted plant, with strong, penetrating odor, but much esteemed by some for flavoring soups, stews, etc. We frequently receive orders for garlic seed, but we can supply bulbs only. Prepare the ground the same as for onions and plant the bulbs in drills eight inches apart, and four inches apart in the rows, and cover two inches deep. When the leaves turn yellow, take up the bulbs and dry in the shade and lay them up in a dry loft as you would onions. Bulbs, $1 / 4 \mathrm{lb} .15 \mathrm{c}$, 1b. 40c. Postage extra, $\frac{1}{2}$ c per oz. 


\section{PAR S LEY}

Parsley is so easily grown and useful for so many purposes that every garden, no matter how small, should have a supply. A very pretty effect is produced if parsley is used as an edging for flower or vegetable beds, and when it is pulled off or cut, shoots out again quickly and keeps up a delightfully fresh, green edging all the season. In the winter parsley can be very profitably grown under glass.

Culture.-Soak the seed in water a few hours, and sow in rich soil early in spring, in rows a foot apart and cover lightly. Parsley is slow to germinate, and it is sometimes three or four weeks in coming up. One ounce will sow one hundred and fifty feet of drill.

Champion Moss Curled. The best and most improved strain. It is beautifully curled and crimped, and is the best for garnishing and flavoring. It makes an ornamental plant for edging walks. Pkt. 5c, oz. $10 \mathrm{c}, \mathrm{s} / 4$ lb. $20 \mathrm{c}, 1 \mathrm{~b}$. $60 \mathrm{c}$.

Plain. Very hardy and stronger in flavor than the curled. Pkt. 5c, oz. 10c, 1/4 lb. 15c, 1b. 50c.
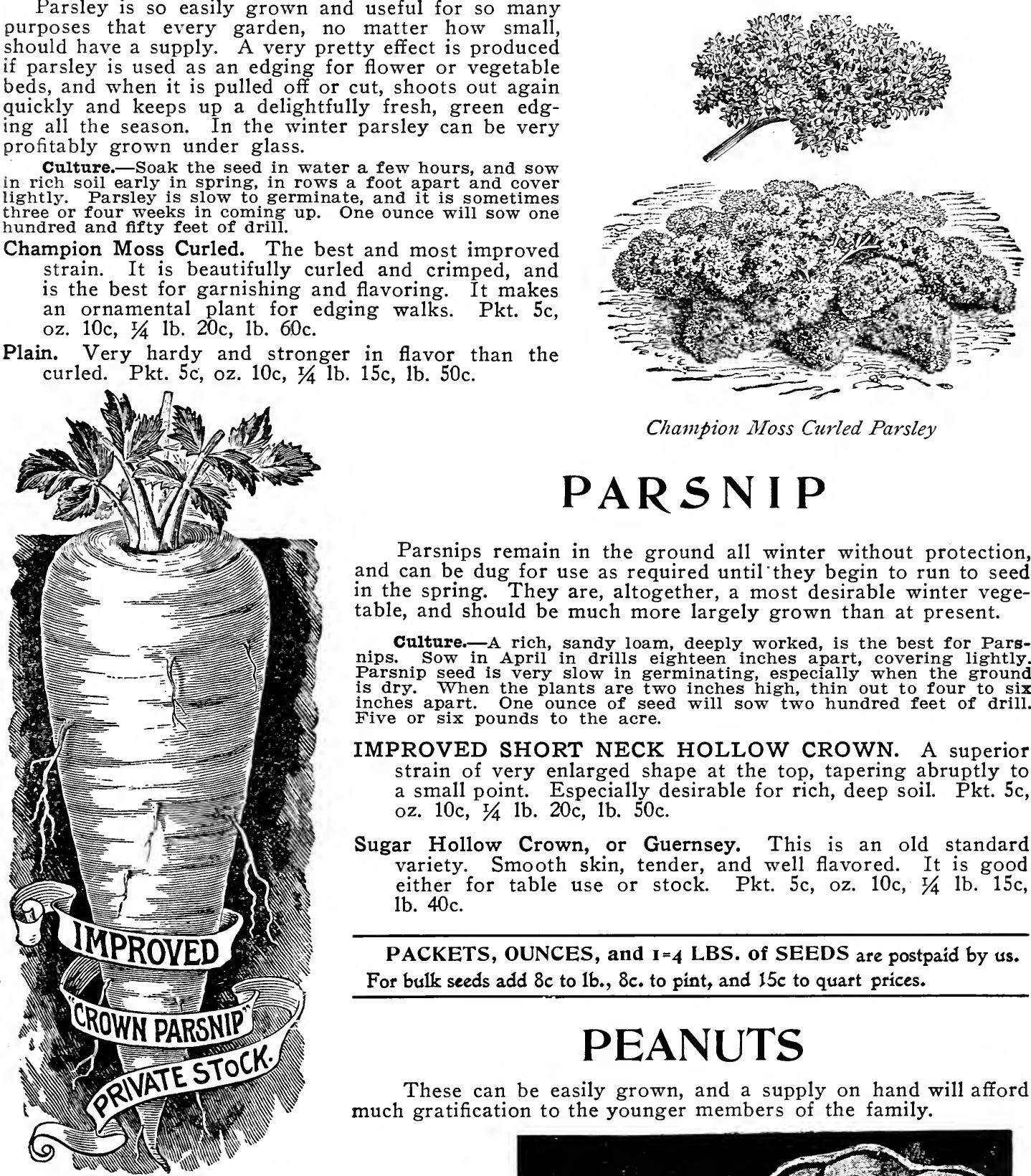

Champion Moss Curled Parsley

\section{PAR S N I P}

Parsnips remain in the ground all winter without protection, and can be dug for use as required until they begin to run to seed in the spring. They are, altogether, a most desirable winter vegetable, and should be much more largely grown than at present.

Culture.-A rich, sandy loam, deeply worked, is the best for Parsnips. Sow in April in drills eighteen inches apart, covering lightly. Parsnip seed is very slow in germinating especially when the ground is dry. When the plants are two inches high, thin out to four to six inches apart. One ounce of seed will sow two hundred feet of drill. Five or six pounds to the acre.

IMPROVED SHORT NECK HOLLOW CROWN. A superior

strain of very enlarged shape at the top, tapering abruptly to a small point. Especially desirable for rich, deep soil. Pkt. 5c, oz. $10 \mathrm{c}, \mathrm{s} / 4$ lb. $20 \mathrm{c}, 1 \mathrm{~b}$. $50 \mathrm{c}$.

Sugar Hollow Crown, or Guernsey. This is an old standard variety. Smooth skin, tender, and well flavored. It is good either for table use or stock. Pkt. 5c, oz. $10 \mathrm{c}, 1 / 41 \mathrm{~b} .15 \mathrm{c}$, lb. $40 \mathrm{c}$.

PACKETS, OUNCES, and $I=4$ LBS. of SEEDS are postpaid by us.

For bulk seeds add $8 \mathrm{c}$ to $1 \mathrm{~b}$., $8 \mathrm{c}$. to pint, and $15 \mathrm{c}$ to quart prices.

\section{PEANUTS}

These can be easily grown, and a supply on hand will afford much gratification to the younger members of the family.

Culture.-Shell the nuts and plant in April or May in drills $21 / 2$ to 3 feet apart, dropping them 12 cultivating flat and keeping the land clean of weeds.

If by mail add 10 cents per quart for postage.

Improved Virginia. A fine productive strain, making large-sized nuts. Qt. 15 c, 4 qts. 40c, bu. $\$ 2.00$.

Spanish. An early, small-sized variety which is enormously prolific, and the kernels are very rich and fine flavored. It is also very largely grown for stock feeding, the vines and roots pulled up and cured making excellent, nutritious hay or very fattening food for hogs. Qt. $15 \mathrm{c}, 4$ qts. $45 \mathrm{c}$, bu. $\$ 2.50$.

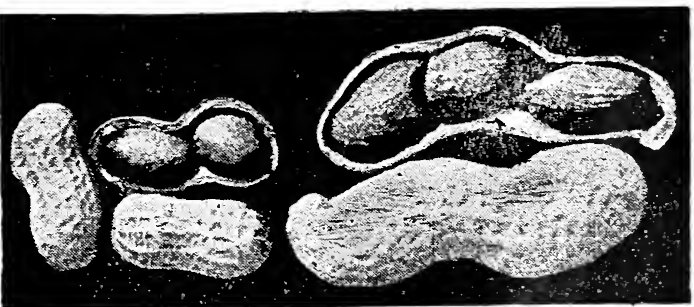

Spanish Peanuts Improved Va. Peanuts 


\section{Crops Very Short}

For Field and Cow Peas see under Field Seeds.

One pint sows 50 feet; $11 / 2$ to 2 bushels to the acre. Earliest sorts can be planted in January or February; wrinkled varieties in March till May. For fall, plant in August. A half pint planted every two weeks will yield a succession and is enough for medium sized garden. Select different sorts.

The varieties we offer are the best in cultivation, the list embracing all classes from the very earliest to the main crop and late sorts.

Pkts. mailed free. In bulk, add 8c per pint; $15 \mathrm{c}$ per qt. if to be mailed.

\begin{abstract}
Culture. - Peas succeed best in light, rich, loamy soil, which has been manured the previous season. Plant in rows two and a half to three feet apart, two inches deep, giving the taller varieties $m$ o re room between the rows. tween therf ties ties can be planted in rows two to two and a half grown as a market crop are rarely ever s t a k ed, b u t when the taller varieties are grown for private use, it is a good plan to is a good plan to sow them in doustaked with brush. They should be They sho uld be earth worked toward them two or three times during growth.
\end{abstract}

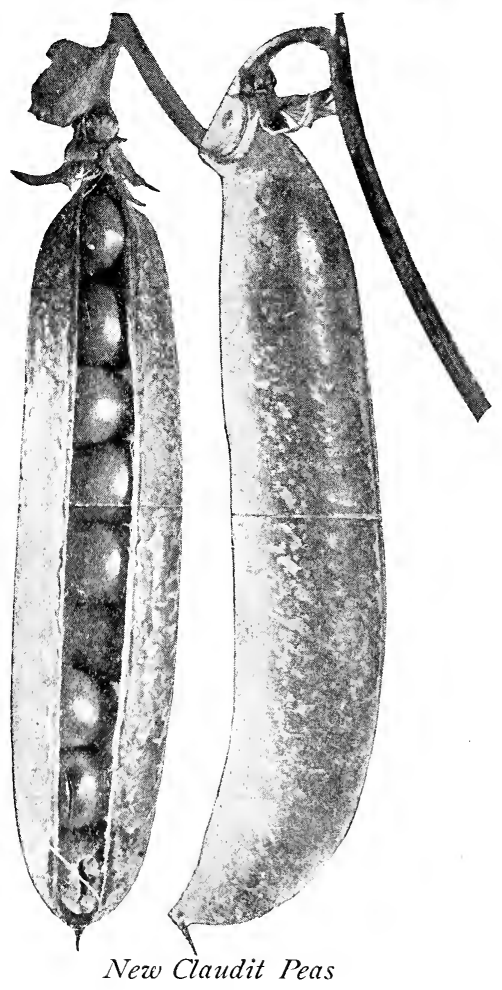

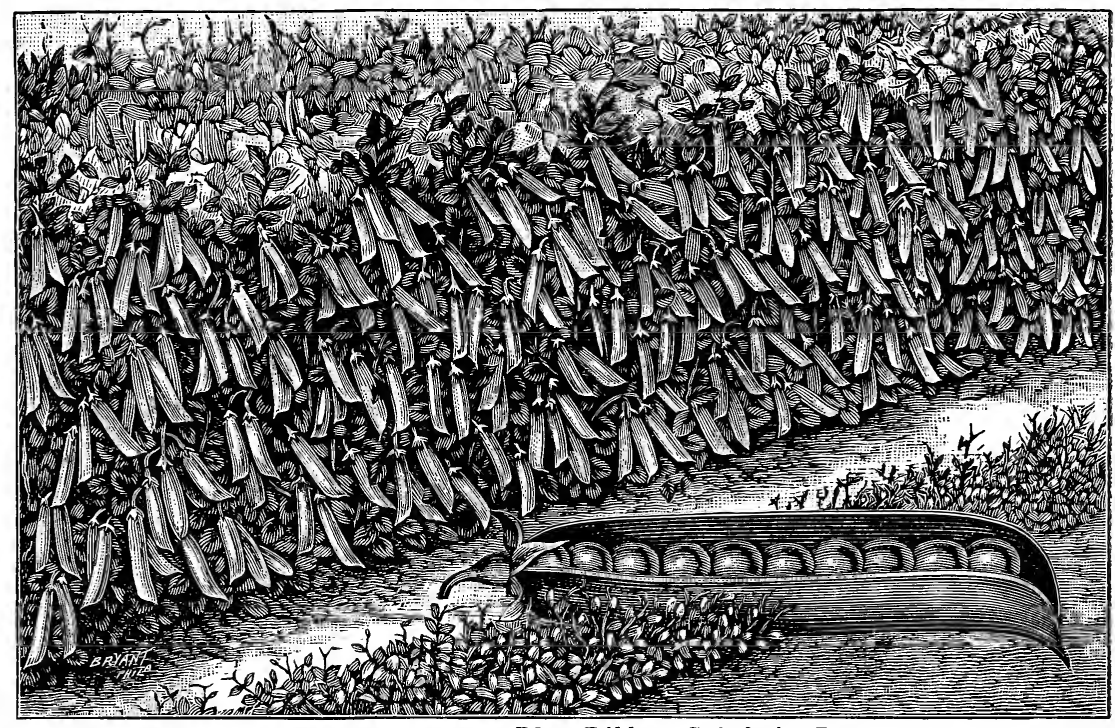

Blue Ribbon Chieftain Peas

\section{EARLY ROUND OR SMOOTH VARIETIES}

These mature in from 48 to 60 days from planting.

BLUE RIBBON CHIEFTAIN. Extra Early. Blue Ribbon Chieftain Peas are the most profitable of all the smooth white peas that can be planted for market, as their extreme earliness, being four or five days earlier than any other sort, is bringing most profitable results. We have had this reported from dozens of growers, and sales are increasing on these enormously. It may be a broad statement, but we firmly believe of all the strains of extra early peas in existence, this is without doubt the earliest and one of the best for yielding. In addition to this, the peas are good size, sell readily, and are most excellent quality. The vines average about eighteen to twenty-four inches in height, depending upon the season; pods are borne in profusion, easily picked and well filled, bearing six to eight peas of the finest quality. We unhesitatingly recommend these for general market growing and for family use. Pkt. 5c, qt. 25c, 4 qts. $75 \mathrm{c}$, bu. $\$ 5.00$.

NEW CLAUDIT. Since the introduction of this sort four or five years ago by us, it has rapidly grown in favor and is now superseding Alaskas. The peas are the same color and average about one and a half times as large, the pods being in about the same proportion. This means that less peas have to be picked to make a barrel. The quality of Claudit Peas for sale on the market is fully equal to Alaska or any other blue peas, and its keeping qualities are better. The vines usually grow $2 x / 2$ feet high, bearing seven to nine peas to the pod, and retaining their freshness a long time after picking. Blue Ribbon Chieftain and Claudit for early market planting can not be surpassed anywhere. Pkt. 5c, pt. $15 \mathrm{c}$, qt. $25 \mathrm{c}, 4$ qts. 85 c, bu. $\$ 5.50$. 


\section{PEAS-Garden Sorts-Continued}

WOOD, STUBBS \& CO.'S EXPRESS. Vines $2 \mathrm{~T} / 2$ feet high bearing in profusion long straight, well-filled pods. Very hardy, vigorous, large yielding as early as Alaska and fine as the main early crop for market or extra daily for home garden

ALASKA. Very popular with market growers and canners. Peas are bluish in color, borne in straight well-filled pods; very early and especially valuable for shipping; the pods remaining green longer than white seeded sorts. Height $21 / 2$ feet.--

First and Best. An old popular strain of extra early white seeded peas. Vines $2 \mathrm{I} / 2$ feet. Very productive and continue to bear longer than most early sorts

Tom Thumb. An older sort of white smooth peas; very dwarf growth, averaging about 10 inches. Very hardy but not so prolific as the above mentioned sorts and valuable only on account of not needing sticks

Pkt. Pt. Qt. 4 qts. Bu.

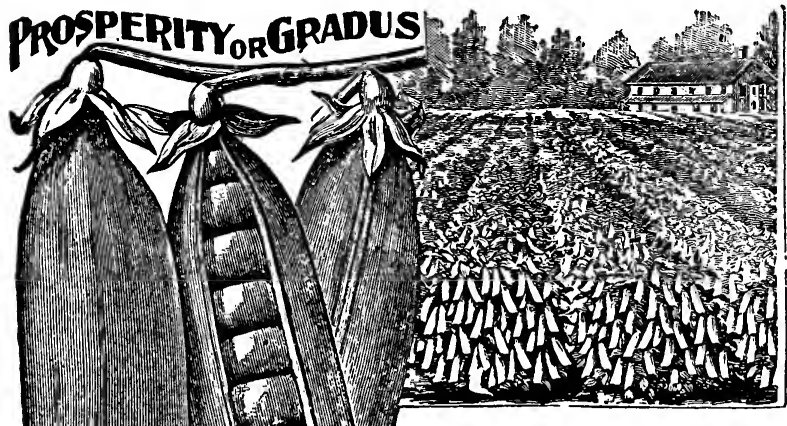

\section{WRINKLED VARIETIES}

The wrinkled peas are the finer, sweeter flavor, and superior to the smooth peas in their table qualities, and on this account are used more generally for the private garden. They are not quite as hardy as the smooth varieties, and on this account should be planted a little later.

\section{Extra Early WrinkIed Peas.}

GRADUS OR PROSPERITY. Undoubtedly the best and earliest large-podded wrinkled pea which has been introduced

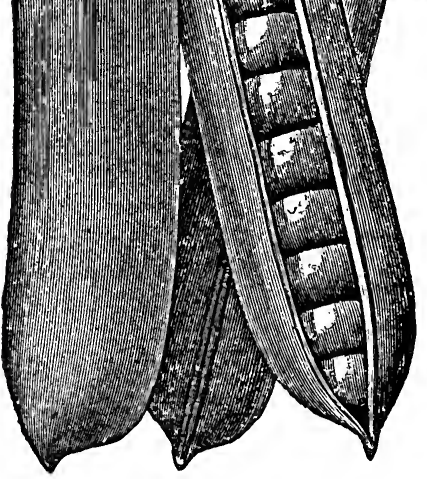

for many years. Newer sorts have come out, but due to their shy bearing and lacking vigor in growth, there has been nothing in our opinion which has surpassed Gradus. Not only is this an extremely early sort, but the pods are about as large as Telephone, hence market gardeners as well as private gardeners all speak well of Gradus. It has heavy stems, large dark green leaves, producing handsome large pods measuring four to four and a half inches in length, nearly round, and are filled with large peas which are tender, sweet, and remain edible longer than most other sorts. Gradus Peas have always been in such demand that the price still stays high. Pkt. 5c, pt. 20 c, qt. 35 c, 4 qts. $\$ 1.15$, bu. $\$ 8.00$.

AMERICAN WONDER. One of the best known of the dwarf early wrinkled peas which has long been a favorite for family use; vines growing about nine inches high, are strong, robust, and remarkably productive. Peas delicious, small, and very sweet. Pkt. $5 \mathrm{c}$, pt. $15 \mathrm{c}$, qt. $25 \mathrm{c}$, 4 qts. 80 c, bu. $\$ 5.25$.

MCLEAN'S LITTLE GEM. A favorite early wrinkled variety maturing a little later than American Wonder, of a somewhat taller growth, and a little more prolific; pods fair length and peas of excellent quality. Pkt. 5c, pt. 10c, qt. 20c, 4 qts. 75 c, bu. $\$ 5.00$.

Premium Gem. Practically the same as McLean's Little Gem.

NOTT'S EXCELSIOR. Although a few days later than the American Wonder, the pods will average fully one-third larger. For a wrinkled pea they are remarkably hardy, and can be planted almost as early as the smooth sorts. Dwarf in habit, of vigorous constitution, and wonderfully productive. Height 1 foot. Pkt. 5c, postpaid; pt. 15c, qt. 25c, 4 qts. 85 c, bu. $\$ 5.50$.

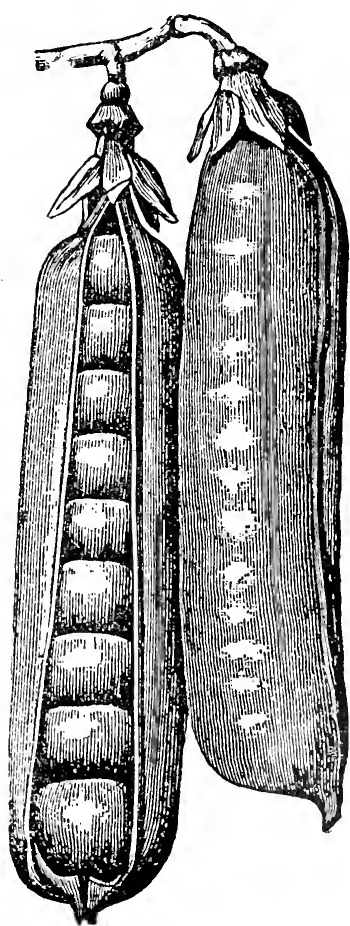

Summer Queen Peas

Jessamine County, Ky., Aug. 24, 1908. As you know Mr. M. C. Rankin sent four bushels of corn into Jessamine County, which he got of you. Mr As W State Fair. The variety was Improved Boone County White. 


\section{MEDIUM CROP PEAS}

SUMMER QUEEN. This is becoming one of the standard sorts for second early planting by gardeners everywhere, and we have never grown or eaten a pea which comes nearer to perfection than this. The peas are large, wrinkled, and of greenish color, sweet, of splendid flavor, and have all the qualities for making them an ideal private sort as well as being productive and profitable for gardeners; height $2 \mathrm{r} / 2$ feet. Pbt. $5 \mathrm{c}$, pt. $15 \mathrm{c}$, qt. $25 \mathrm{c}, 4$ qts. $75 \mathrm{c}$, bu. $\$ 5.50$

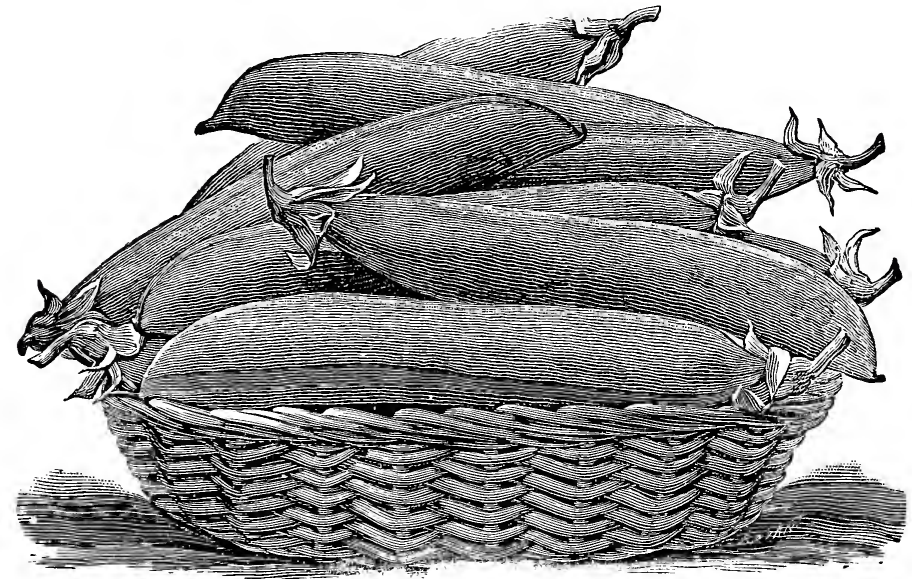

Improved Telephone Peas
IMPROV E D
PRIDE O F THE MARKET. A very p r o d u c tive variety, bearing large and $\mathrm{h}$ a nd som e pods we 11 fill e d with peas of splendid q u a lity. Very popular sort for the private $\mathrm{g}$ a $\mathrm{r}$ den and market. Height $11 / 2$ to 2 feet. Pkt. 5c, postpaid; pt. $15 \mathrm{c}$, qt. $25 \mathrm{c}, 4$ qts. $85 \mathrm{c}$, bu. $\$ 6.00$.

Heroine. A medium early green wrinkled pea coming in between Advancer and Champion of England. Grows two to two and a half feet high, and bears in great profusion long, slightly curved, pointed pods containing nine or ten large peas of finest quality. An extremely desirable sort for market or home use. Pkt. 5 c, postpaid; pt. 10 c, qt. 20 c, 4 qts. 75 c, bu. $\$ 5.00$.

\section{Late or Main Crop Peas}

STRATAGEM. A remarkably fine pea. The vines are almost completely covered with large, well-filled pods. Sweet and delicious. Height $11 / 2$ feet. Pkt. 5c, postpaid; pt. 15 c, qt. 25 c, 4 qts. 90 c, bu. $\$ 6.00$.

CHAMPION OF ENGLAND. Universally admitted to be one of the best late peas grown. Of delicious flavor and a very profuse bearer. One of the best for market or private garden. Height 4 to 5 feet. Pkt. $5 \mathrm{c}, \mathrm{pt}$. $10 \mathrm{c}$, qt. 20c, 4 qts. 60 c, bu. $\$ 4.00$.

IMPROVED TELEPHONE. One of the most productive of the wrinkled peas. Of excellent sugary flavor. Rather late in maturing, but one of the best for main crop. Height 4 feet. Pkt. 5c, pt. 15 c, qt. 25 c, 4 qts. 85 c, bu. $\$ 6.00$.

LARGE WHITE MARROWFAT. Late variety, large, well-filled pods. Vines

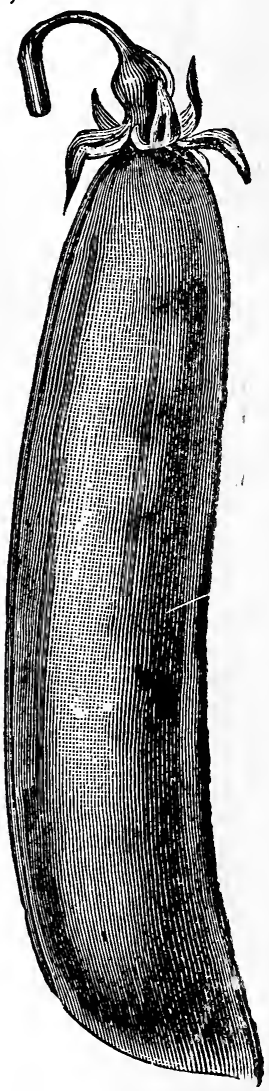

Improved Pride of the Market hardy, strong, and vigorous, pods fine, broad, and of a leathery appearance and borne near the top of the vine. Contain five or six large peas of good substance and flavor, but not sweet like the wrinkled sorts. The peas are large, round, white, and slightly oval. Height of vine $31 / 2$ feet. Pkt. 5c, pt. 10c, qt. $15 \mathrm{c}, 4$ qts. $40 \mathrm{c}$, bu. $\$ 2.50$.

BLACK EYE MARROWFAT. Growth and general characteristics similar to above. The peas having a distinct black eye, which does not show when they are in the green state. Is more prolific than the white. Pkt. 5c, pt. $10 \mathrm{c}$, qt. $15 \mathrm{c}, 4$ qts. $40 \mathrm{c}$, bu. $\$ 2.50$.

For a large, quick crop of Hay, sow Canada Field Peas. For description and prices see Farm Seeds.

\section{SWEET POTATOES}

Our seed is grown in Jefferson County, $\mathrm{Ky}$. This county has a splendid reputation for producing the finest and best flavored sweet potatoes in the country.

Culture.-Put the potatoes into hot beds in April, covering with three inches of earth, and after they begin to grow, give plenty of air on sunny days and water regularly. In May or June set out in rows three feet apart and fifteen inches apart in the rows. The land should be plowed shallow in order to produce the short, chunky potato most largely in demand. Apply a fertilizer having only a small percentage of nitrogen and a large amount of potash, such as Acme Brand Potato Fertilizer.

We can supply the following varieties in April: Yellow Jersey, Nansemond, Southern Queens, White Yams, Bermuda, Red Jersey, and Red Nansemond.

Price of all varieties about 50c per peck; bushel and barrel prices quoted on application.

PARIS GREEN and BUG and BLIGHT DUST No. 3 are the two standard remedies for Potato Bug, the latter remedy both killing bugs and preventing blight. They are best applied with either a Champion Paris Green Gun, or in large areas a Beetle Four Row Potato Duster. For descriptions and prices see Insecticides and Dry Powder Guns. 


\section{\& SELECTED SEED POTATOES}

\section{Northern and Second Crop. Crops very short. IMPORTANT NOTICE}

The prices of Potatoes are constantly changing. Please write us for current market prices when ready to purchase. Second crop stocks are very short. Order early and suggest a next choice in case we are out of the sort you desire. State distinctly whether NORTHERN or SECOND CROP stocks are desired.

Prices on barrels of Potatoes are fur full-sized flour-barrels; sacks, 11 pecks. If wanted in barrels, add 20 cents for tho barrel. Prices given include sacks on all quantities.

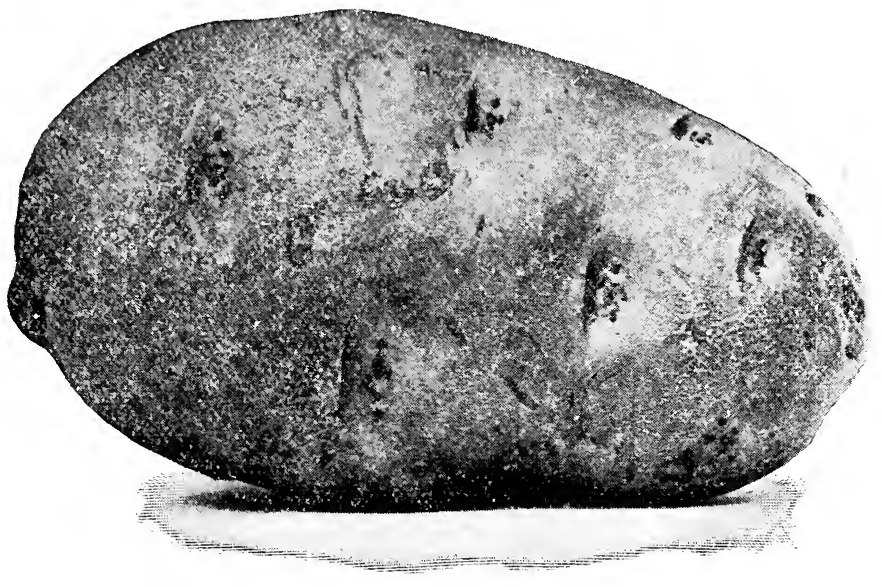

New Early Sunlight Potato

NEW EARLY SUNLIGHT. This fine new extra early white potato resembles Irish Cobbler, except that it is a little longer in shape, and is fully ten days earlier. It has been planted for two or three years in the principal potatogrowing sections of Virginia and the Carolinas, and in most sections has superseded all other early sorts, being superior in yield and taking premiums wherever exhibited. So universal has the planting of Sunlight become in some sections that it is impossible to buy other sorts. It is pure white, somewhat deep eyes, very smooth skin, and extra fine appearance, and the very earliest potato of good cooking quality. Vines are medium height, stock thrifty and not subject to blight. Potatoes are produced close to the vine, hence can be planted closely. We strongly advise all growers of early potatoes for market to get in stock of Sunlight, and for family use there is nothing superior.

Choice Second Crop Stock. Per pk. 75c, bu. \$2.50, 11-pk. sack \$5.75.

IRISH COBBLER. This has become one of the general favorites in all localities for early as well as late planting. When it was first sent out it was not claimed to be particularly early, but extensive growing in this locality proves that it is fully as early as Queen or Hebron. The yield at digging both before the potatoes are ripe, and after maturity, is very large and far superior to many of the high-priced "novelties," besides nearly all ordinary sorts in general use. The particular features which impress our many growers are the general thriftiness of the vines, combined with a remarkably large yield of fine, large, most attractive, pure, white-skinned potatoes. The tubers are round in shape, eyes somewhat deep, and tubers of both fine appearance and quality. There is a heavy demand for Irish Cobbler potatoes from all sections and stocks are short, therefore we advise early orders.

Second Crop. Pk. 60c, bu. $\$ 2.00$, bbl. about $\$ 5.00$.

Choice Maine Stock. Pk. 60c, bu. $\$ 2.00$, bbl. about $\$ 5.00$.

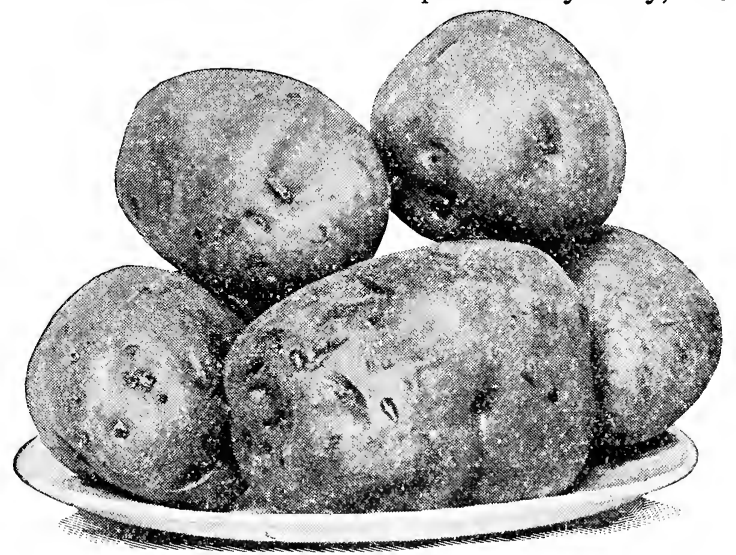

Irish Cobbler Potatoes

EARLY BOVEE. A very popular variety among many growers in this section. It is extra early, prolific, forms of good size potatoes, and splendid for market or family use. Vines rather dwarf, tubers are compact in the hill, and has few small potatoes. Color white, eyes shallow, quality excellent. Choice Maine Stock and Second Crop Stocks. Pk. 50c, bu. \$1.75, bbl. about $\$ 4.50$.

EARLY SIX WEEKS. A very early potato, claimed to mature in six weeks, and especially recommended for early markets and family use. A very large yielding variety, smooth skin, slightly blushed, shallow eyes, and of good appearance. They are of fine texture, good quality, cook mealy and white.

Choice Maine and Second Crop Stocks. Pk. 60c, bu. $\$ 2.00$, bbl. about $\$ 5.00$.

\section{SEED POTATOES FROM COLD STORAGE FOR LATE PLANTING.}

We expect to carry a fair stock of potatoes in cold storage so as to be able to furnish them in good condition for planting in July and August. It is, however, impossible to give full list of varieties and prices here, but we will take pleasure in quoting these on request. 


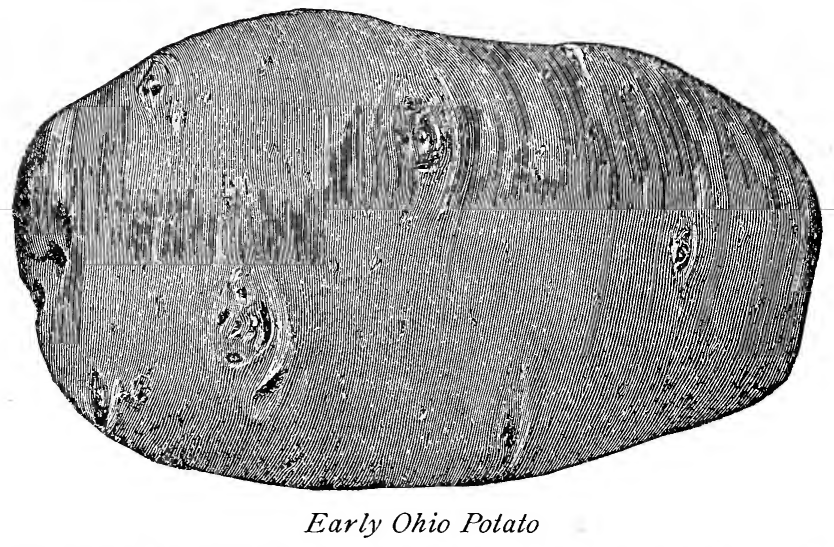

EARLY OHIO. A favorite variety among gardeners everywhere, and particularly well suited to light or loamy soil, though it succeeds well nearly everywhere. The tubers are oval, have few eyes, smooth skin, color white, slightly flushed with rose, and is of excellent quality. A favorite sort for early market or family use.

Northern. $\mathrm{Pk} .50 \mathrm{c}$, bu. $\$ 1.50$, bbl. about $\$ 4.00$.

EARLY PURITAN. A pure white early potato which is particularly suitable to light, loamy soil. Good yielder, oblong shape, shallow eyes, very salable, and fine quality.

Choice Maine and Second Crop Stocks. Pk. 50 c, bu. $\$ 1.75$, bbl. about $\$ 4.50$.

BLISS' TRIUMPH. One of the earliest and largely planted by truckers and gardeners for early crop, being mostly shipped to Northern markets. Vines are of medium growth, yields very well. Potatoes round, with deeply indented eyes, and of pink skin.

Choice Northern and Second Crop Stocks. Pk. 50c, bu. $\$ 1.70$, bbl. about $\$ 4.50$.

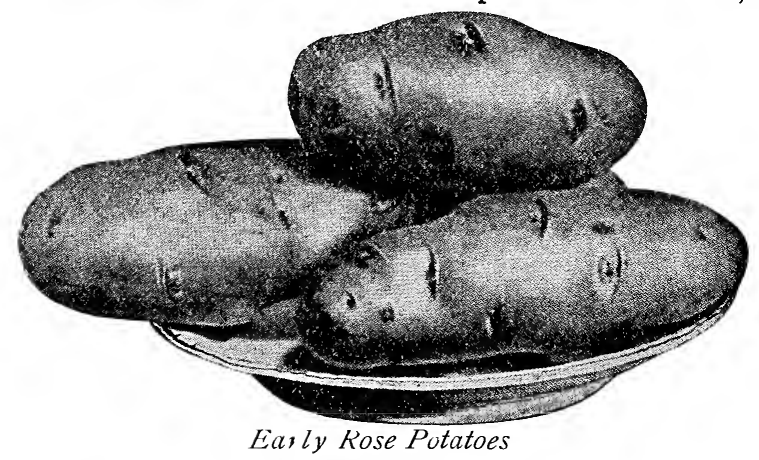

EARLY ROSE. One of the older varieties, and still largely planted, many growers claiming that it has never been superseded in quality and productiveness. Potatoes are oblong, light pink color at the bud end, cooks mealy, and of the finest flavor.

Northern. Pk. 40c, bu. $\$ 1.25$, bbl. about $\$ 3.00$. NEW QUEEN. A splendid variety, resembling the old Beauty of Hebron in appearance, color, and shape, but somewhat earlier and a heavier yielder. Potatoes are oblong with few eyes. Skin white, slightly flushed with rose, flesh pure white, and cooks dry and mealy. Very popular everywhere, and succeeds well on nearly all classes of soil. It is a good keeping variety and brings the best prices.

Choice Maine and Second Crop Stocks. Pk. 50c, bu. $\$ 1.75$, bbl. about $\$ 4.50$.

THORBURN. Largely planted by growers in this section, and is well suited to heavy loams. Potatoes are slightly oblong, skin slightly flushed with pink, smooth, and good quality. A good variety for main early crop for market or home use.

Second Crop. Pk. 50c, bu. $\$ 1.75$, bbl. about $\$ 4.50$.

BEAUTY OF HEBRON. Potatoes are oblong, skin white, slightly tinted, flesh pure white, a splendid cooking variety and excellent flavor. It has always been popular with gardeners and for private use, yielding well.

Northern. Pk. 40c, bu. $\$ 1.25$, bbl. about $\$ 3.00$.

Choice Maine and Second Crop. Pk. 50c, bu. $\$ 1.70$, bbl. about $\$ 4.50$.

\section{Late Varieties}

BLUSH. Oval shape, light pink, smooth skin, eyes shallow and fair quality. Potatoes average good size, usually heavy yielding, especially on stiff ground, and one of the best keeping sorts for winter.

Second Crop. Pk. 50c, bu. $\$ 1.60$, bbl. about $\$ 4.00$.

CARIMAN No. 3. A fine round, pure white potato with smooth skin, shallow eyes, and of fine keeping and cooking qualities. It is a good yielding sort, vines vigorous and productive and a fine medium late pure white sort for market or family use.

Second Crop. Pk. 50c, bu. $\$ 1.60$, bbl. about $\$ 4.00$.

WHITE STAR. This wonderful yielding variety is the result of crossing the Excelsior with the White Peachblow. It is medium early or late, of large size, blush white color, of the finest quality, and is an excellent keeper.

Second Crop. Pk. $50 \mathrm{c}$, bu. $\$ 1.60$, bbl. about $\$ 4.00$.

BURBANK. Of the late Northern sorts this is more largely used than any other. It is of
good size, oblong shape, and an excellent yielder. The flesh is white, and is very mealy and of fine flavor.

Northern. $\mathrm{Pk}$. 35c, bu. $\$ 1.00$, bbl. about $\$ 2.75$. white

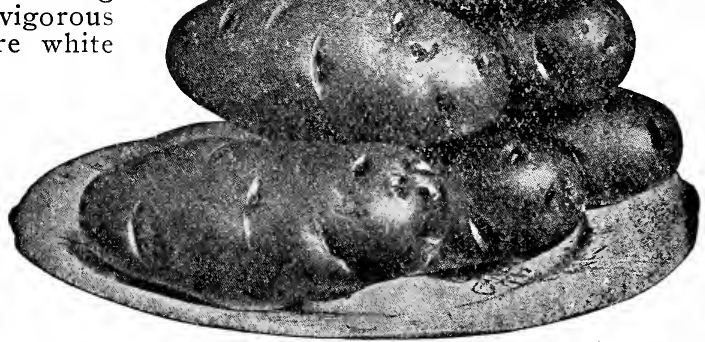

Burbank Potatoes 
Culture.-Sow in hot bed in February or March, and transplant in open ground in May, in rows two to two and a half feet apart, fifteen inches between the plants, or when the ground becomes warm, sow in open ground and set out as above. When transplanted apply liquid manure or some good fertilizer.

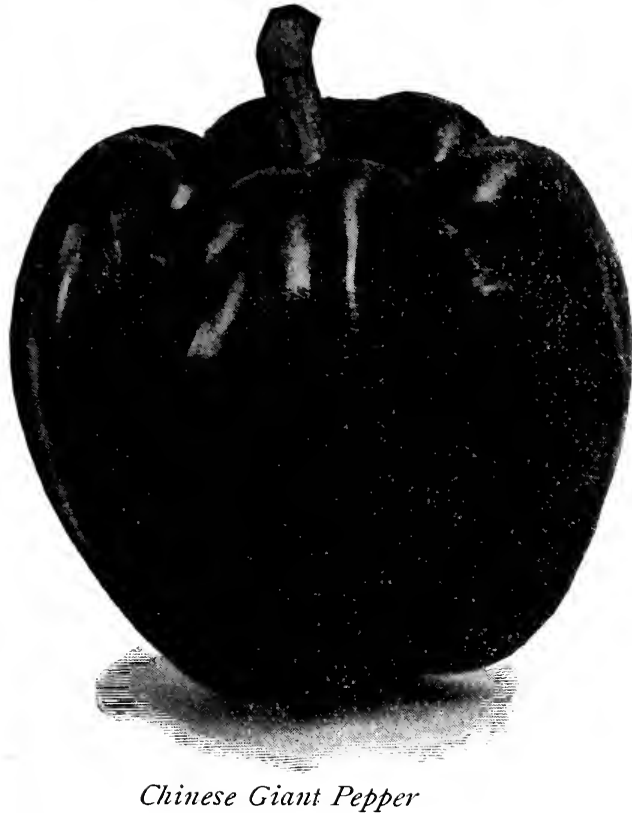

CHINESE GIANT. An enormous sort, sometimes measuring six inches in diameter. Very handsome, mild, and superior quality for stuffing. Plants are vigorous and very prolific, and peppers are late maturing. We strongly recommend this, either for home use or market for main and late use. Pkt. 5c, oz. 40c, $1 / 4$ 1b. $\$ 1.25,1 \mathrm{~b}$. $\$ 4.50$.

CORAL GEM BOUQUET. A dwarf-growing pepper, producing hundreds of small, bright red peppers thickly set on the plants so as to give the plants a most beautiful appearance. Pkt. 5c, oz. 25c, 1/4 lb. 80 c, 1 b. $\$ 3.00$.

RUBY KING. One of the large-sized peppers, fruits four to six inches long; mild, pleasant, dark glossy green, turning to ruby red when ripe. Splendid for stuffing, salad, or pickles. Pkt. 5c, oz. $20 \mathrm{c}, 1 / 4 \mathrm{lb}$. $60 \mathrm{c}, 1 \mathrm{~b}$. $\$ 2.00$.

Mammoth Golden Queen. Fruits six inches long by nine to ten in circumference, and are borne twelve to fifteen to each plant. Mild and sweet. Use as described for Ruby King. Pkt. 5c, oz. 25c, $1 / 41 \mathrm{l}$. $60 \mathrm{c}, 1 \mathrm{~b} . \$ 2.25$.

Sweet Spanish Mammoth. Fine for mangoes. Large, of splendid quality. Pkt. 5c, oz. $20 \mathrm{c}, 1 \mathrm{~b} . \$ 2.00$.

Bell, or Bull Nose. A large early sort, of mild flavor. Color purplish red. Pkt. 5c, oz. $20 \mathrm{c}, 1 / 41 \mathrm{~b} .60 \mathrm{c}$, 1b. $\$ 2.00$.

Long Red Cayenne. A bright red hot variety, of long shape, called "Ladyfinger Pepper." Pkt. 5c, oz. $20 \mathrm{c}, \mathrm{t} / 4$ 1b. $60 \mathrm{c}, 1 \mathrm{~b} . \$ 2.00$.

Red Chili. Very hot, small, thin; coral red color. Pkt. 5c, oz. 25c, 1/4 1b. 65c, 1b. $\$ 2.25$

Red Cherry. Small round fruits. Very prolific. Pkt. 5c, oz. 25c, 1/4 lb. 65c, 1b. $\$ 2.25$.

\section{PUMPKIN}

One oz. plants from 20 to 30 hills; 2 to $3 \mathrm{lbs}$. per acre.

Are usually planted in cornfields to grow with corn for winter feed. They are considered a very healthy and most nutritious food for cattle in winter. In addition to their value as a stock food, they are also largely used for culinary purposes, the finer grained varieties making excellent pies.

Culture-Plant in May in hills eight feet apart, mixing a shovelful or two of well-rotted manure in each hill. Put eight or ten seeds in each hill and cultivate till the vines get strong, when they should be thinned out, leaving two or three of the strongest plants in each hill.

KENTUCKY MAMMOTH PUMPKIN. An exceedingly large variety, well adapted to the South, and one that will give the best and most satisfactory results. Notwithstanding the enormous size of this variety, the flesh is fine grained and of excellent flavor. Pkt. 5c, oz. $15 \mathrm{c}, \mathrm{T} / 4$ 1b. $40 \mathrm{c}, 1 \mathrm{~b} . \$ 1.25$.

JAPANESE PIE. A variety of large size, ranging in weight from thirty to eighty-five pounds. Color of outside rind bluish green, blotched with yellow; flesh salmon, very thick, sweet, and of good flavor. Fine for either stock or making pies. Pkt. 5c, oz. $10 \mathrm{c}, \mathrm{s} / 4$ 1b. $20 \mathrm{c}, 1 \mathrm{~b} .50 \mathrm{c}$.

CASHAW, or CROOKNECK. One of the best table sorts; also fine for stock feeding. Very productive and grows to a large size. Pkt. 5c, oz. $10 \mathrm{c}, 1 / 4 \mathrm{lb}$. $25 \mathrm{c}, 1 \mathrm{~b} .80 \mathrm{c}$.

LARGE CHEESE. A fine, large, flattened pumpkin of splendid quality. Excellent for cooking. Oz. 5c, $1 / 4$ lb. $15 \mathrm{c}, 1 \mathrm{~b} .40 \mathrm{c}$.

TENNESSEE SWEET POTATO. Of medium size; creamy white, with light green stripes; flesh quick, fine grained, dry, brittle, and of excellent flavor. Unsurpassed for pies and custards. Pkt. 5c, oz. 10 c, $1 / 4$ lb. 25 c, 1 b. 85 c.

KENTUCKY FIELD. Splendid for stock feeding. Grows to a large size, round, and of yellow color. Oz. 5c, 1/4 1b. 10c, 1b. 25c, 5 lbs. 20c per 1b. Special prices on large lots.

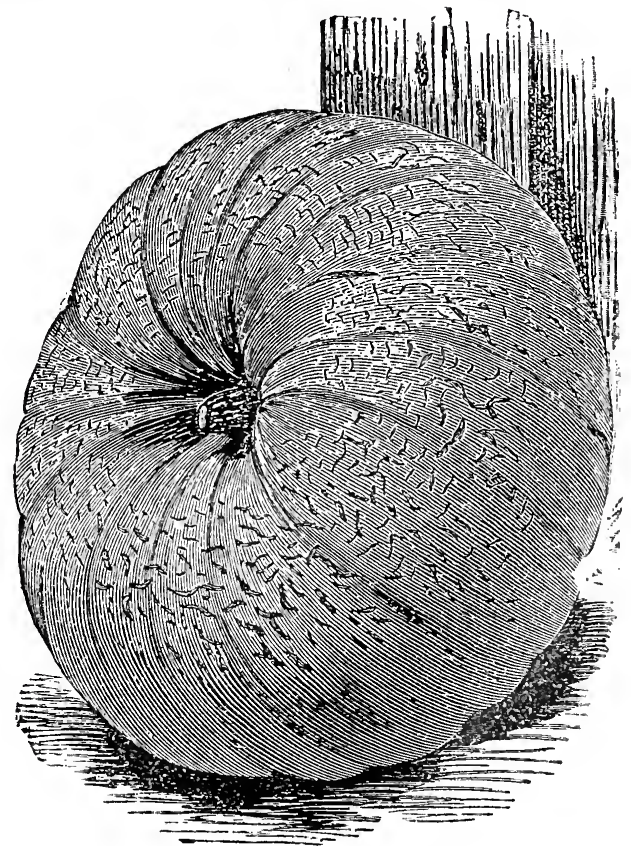

Kentucky Mammoth Pumpkin 
Pkts. 5c; 6 for 25c. Pkts., ounces, and $\mathrm{r} / 4$ lbs. mailed free. To $1 \mathrm{~b}$. prices add $8 \mathrm{c}$ for postage.

One ounce sows 100 feet of drill; 10 to $12 \mathrm{lbs}$. to the acre. For forcing sow in January or February in frames. Outdoors from February to June. For late use, from July to September. Early sorts are ready for the table 21 to 30 days from sowing.

Culture.-To be tender and crisp, Radishes must be grown quickly, and quick growth requires rich soil and plenty of moisture. Commencing with the first mild spell of weather in the spring, sow at intervals of ten days in a light, rich soil that has been deeply dug. They can also be grown as a catch crop between rows of beets, lettuce, onions, etc. Radishes can be forced in the hot beds, but they must have plenty of ventilation and moisture.

EXTRA EARLY WHITE TIP FORCING. Radishes of this type are extremely popular in this locality, both for gardeners and private use. The outer skin is bright crimson color with white tip; flesh pure white. Our strain of this variety is superior to most stocks offered, making a nice, globe-shaped, clean root, with no lateral roots; has very small top and grows much quicker than ordinary strain of White Tip Scarlet. On account of its small top is it largely used for forcing, and extremely satisfactory for earliest use out of doors. Pkt. 5c, oz. 10 c, $1 / 4$ lb. 20 c, 1 b. 50 c.

EXTRA EARLY WHITE BOX. A small, beautiful, pure white sort, of exceedingly quick growth, forming handsome round white roots of pearly white color. Gardeners who have grown this pronounce it the best round white radish for under glass, and it brings the best market prices. It has a small top, and is excellent for family use as well as market. Pkt. 5c, oz. 10c, I $/ 4$ 1b. 20c, 1b. 50c.

NEW WHITE ICICLE. This variety has rapidly become a favorite, in fact there is nothing which has proven superior in this class. It produces beautiful long white roots extremely early, hence decidedly popular for forcing, and a splendid sort for light, deep soil for out of doors. In twenty-five days after sowing this radish is ready for pulling, and it retains its excellent qualities longer than any of the early varieties, not getting pithy so soon. Can be sown from under glass from winter through the early spring, and out of doors in spring and early summer. Pkt. 5c, oz. 10c, $1 / 4$ 1b. 20c, 1b. 60c.

NEW ROUND SCARLET CHINA. This splendid new variety has a brilliant crimson color, very showy, and is one of the finest of all for general purposes, as it does not get pithy for a long time after ready to pull. It is round shape, flesh pure white, of excellent quality, grows very large if allowed to stand, and can be used at all stages after the roots have formed. We unhesitatingly recommend this sort as profitable for market gardeners and satisfactory for private uses. Pkt. 5c, oz. 10c, I/4 1b. 20c, 1b. 60c.

EXTRA EARLY SCARLET GLOBE. One of the finest for forcing or early sowing outside. The roots are slightly oval, of beautiful crimson color, finely shaped, and one of the most attractive in appearance. Tops small, few lateral roots, nice and clean. In many sections this is the most popular of all with market gardeners. Pkt. 5c, oz. 10c, 1/4 1b. 20c, lb. 50c.

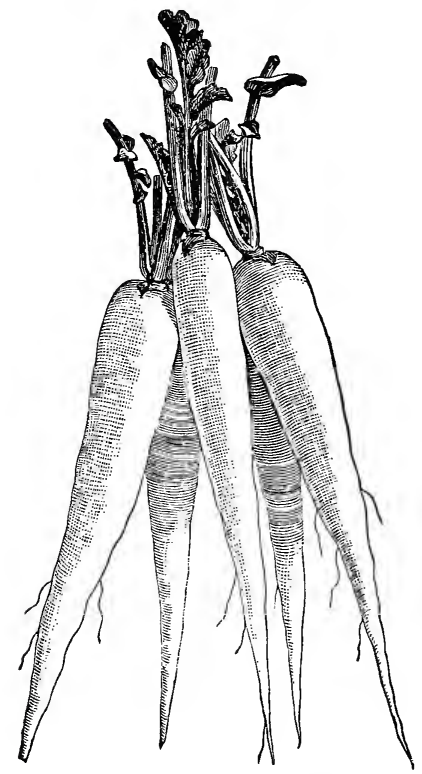

New White Icicle Radish

WHITE STRASBURG. The most popular of all radishes in the West for outside, second early or main summer crop. It grows to large size, does not get pithy unless very old, of beautiful crystal white color, tender and sweet. Roots are tapering, about two inches thick, and five inches long. Pkt. $5 c$, oz. $10 \mathrm{c}, 1 / 4 \mathrm{lb}$. $15 \mathrm{c}, 1 \mathrm{~b} .50 \mathrm{c}, 5$ lbs. at $45 \mathrm{c}$.

Early White Tipped Scarlet Turnip. Bright red, shading off to white at the tip. Splendid for earliest sowing outside. Flesh white and tender, roots very showy. Pkt. 5c, oz. 10c, 1/4 lb. $15 \mathrm{c}, 1 \mathrm{~b}$. $50 \mathrm{c}, 5 \mathrm{lbs}$. at $45 \mathrm{c}$.

French Breakfast. An old popular early sort; roots oblong, bright red, shading to white at the tip. Pkt. 5c, oz. $10 \mathrm{c}, 1 / 4 \mathrm{lb} .15 \mathrm{c}$, lb. $40 \mathrm{c}$.

EARLY RED, or SCARLET TURNIP. Dark crimson color, with white flesh. Splendid general early use, as it does not get pithy as soon as most of the early sorts. Pkt. $5 \mathrm{c}, \mathrm{oz} .10 \mathrm{c}$, $1 / 41 \mathrm{~b} .15 \mathrm{c}, 1 \mathrm{~b} .40 \mathrm{c}$.

Early White Turnip. Similar to the above, except that the skin is white. Pkt. 5c, oz. 10c, $1 / 4$ lb. 15c, 1b. 40c.

Mixed Turnip. A mixture of the various turnip-shaped varieties. Pkt. 5c, oz. $10 \mathrm{c}, 1 / 4 \mathrm{lb} .15 \mathrm{c}, 1 \mathrm{~b} .40 \mathrm{c}$.

Non Plus Ultra. Deep scarlet, globe-shaped, small top; desirable for frames or outside. Pkt. $5 \mathrm{c}$, oz. $10 \mathrm{c}, 1 / 4 \mathrm{lb} .15 \mathrm{c}, 1 \mathrm{~b}$. $50 \mathrm{c}$.

Brightest Long Scarlet. Roots bright crimson, crisp and tender. Matures in twenty-five days; has a small top, and a very attractive and superior sort. Pkt. 5c, oz. $10 \mathrm{c}, 1 / 4 \mathrm{lb}$. $15 \mathrm{c}, 1 \mathrm{~b} .40 \mathrm{c}$.

Woods' Early Frame. Similar to the above, except that the roots are a little thicker. Tender, crisp and fine quality. Pkt. 5c, oz. 10 c, $1 / 4$ lb. 15 c, $1 b .40$ c. 


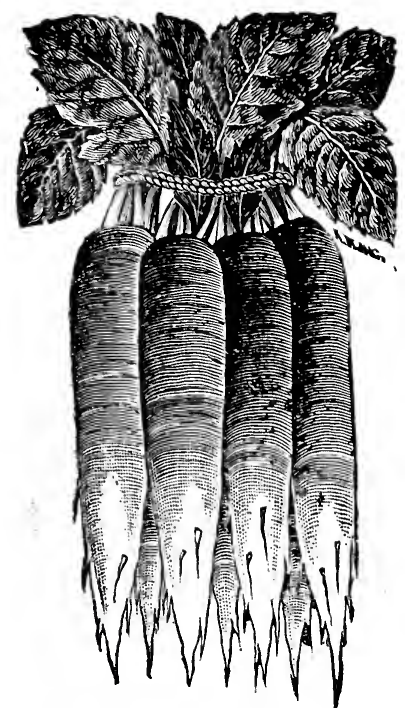

Chartier Long Scarlet Radish

CHARTIER LONG SCARLET. Brilliant scarlet, shading to white at the tips. One of the best for summer and main crop, as it will grow to immense size without becoming pithy or strong. Pkt. 5c, Oz. $10 \mathrm{c}, \mathrm{r} / 4$ lb. $15 \mathrm{c}, 1 \mathrm{~b} .40 \mathrm{c}$.

Long White Naples. Longer and not so thick as White Strasburg. Very much liked by shippers, and splendid quality. Pkt. $5 \mathrm{c}, \mathrm{oz} .10 \mathrm{c}$, $1 / 4$ lb. $15 \mathrm{c}, 1 \mathrm{~b} .40 \mathrm{c}$.

Giant White Stutgart. Produces large top, shaded white roots, sometimes four inches in diameter. Does not get pithy, hence valuable either for summer use or for storing for winter. Pkt. 5c, oz. 10c, $1 / 4$ 1b. $15 \mathrm{c}, 1 \mathrm{~b} .40 \mathrm{c}$.

Golden Globe Summer. Round, russet-colored skin, with white flesh; of good size, valuable for summer, as it does not get pithy. Pkt. 5c, oz. $10 \mathrm{c}, \mathrm{t} / 4 \mathrm{lb} .15 \mathrm{c}, 1 \mathrm{~b} .40 \mathrm{c}$.

ROSE CHINA WINTER. One of the best fall and winter varieties. Half long shape; upper part bright crimson, shading to white. Flesh white, firm, tender, and of superior quality. Pkt. 5c, oz. 10c, $1 / 4$ lb. 20c, 1b. 60c.

Round Black Spanish. Outer skin black, flesh white and tender. Pkt. 5c, oz. $10 c, 1 / 4$ lb. 20c, 1b. 60c.

Long Black Spanish. Long, black roots; flesh white and tender. Splendid for very late use. Pkt. 5c, oz. $10 \mathrm{c} ; 1 / 4 \mathrm{lb}$. 20c, 1b. 60c.

Long White Spanish. Similar to above, except outer skin is white.

Pkt. 5c, oz. 10 c, $1 / 4$ lb. 20c, 1b. 60 c.

\section{Rhubarb or Pie Plant}

One ounce sows 75 feet; about six lbs. to the acre. About 24 roots are sufficient for an ordinary garden. Plant roots in March or November. Sow seed in April.

culture.-Sow in drills in a shady or moist situation, and when a few inches high thin out to 12 inches. The following fall transplant to a deep, well-manured soil, three by four feet apart and protect with manure or leaves. It may be more quickly grown by setting out the manure or leaves. It may be more quickiy grown by setting out the roots, covering the crown every fall with coarse manure.

MYATT'S VICTORIA. The best variety for the South. Pkt. 5c, oz. $15 \mathrm{c}, \mathrm{I} / 4$ lb. $40 \mathrm{c}, 1 \mathrm{~b} . \$ 1.25$.

RHUBARB ROOTS. $10 \mathrm{c}$ each; $75 \mathrm{c}$ per dozen. Price by the $100 \$ 4.50$. If to be mailed add $10 \mathrm{c}$ each for postage.

SALSIFY، One ounce sows 100 feet; three pounds per acre. Sow in March or April.

Culture.-Sow in a rich, light, deeply-worked soil, in rows 18 inches apart, and thin out to four or six inches. Cultivate often to keep down weeds. It is perfectly hardy, and may remain out all winter.

MAMMOTH SANDWICH ISLAND. A great improvement over

the old sort, growing double the size. Quality excellent. Pkt.

5 c, oz. $10 \mathrm{c}, \mathrm{I} / 4 \mathrm{lb} .35 \mathrm{c}, 1 \mathrm{~b} . \$ 1.00$.

\section{SPINACH}

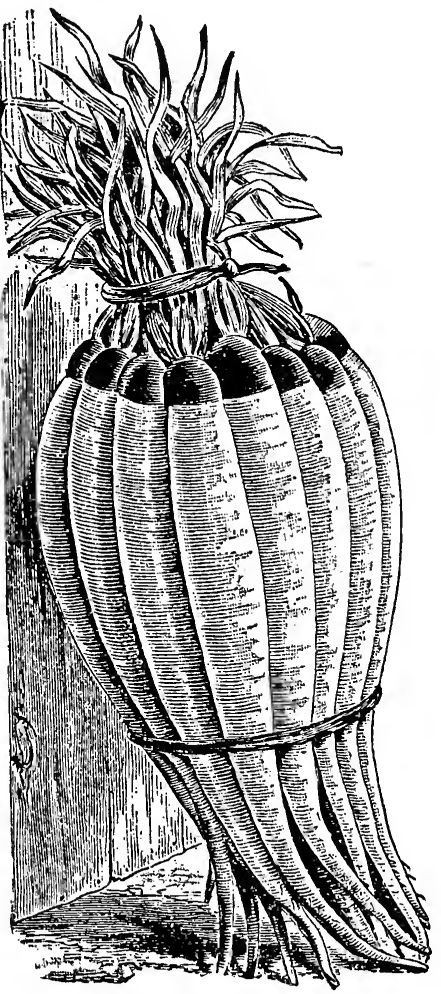

Salsify

One ounce sows 100 feet of drill; $20 \mathrm{lbs}$ per acre in drill; 25 to $30 \mathrm{lbs}$. broadcast. $\mathrm{I} / 2 \mathrm{lb}$. is sufficient for a medium garden. Sow February, March, or April. For fall and early spring sow in September or October.

Culture.- Sow in drills one inch deep, eighteen inches to two feet between the rows, or it can be sown broadcast like Kale. Requires but little or no cultivation.

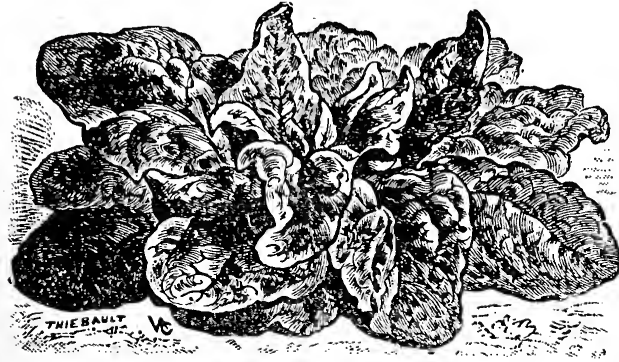

New Victoria Spinach

NEW VICTORIA. An excellent sort which has very thick dark green leaves, somewhat curled in center. It is one of the earliest of all varieties, and remains so much longer before going to seed than most kinds that it can not fail to please. Excellent either for market or private garden. Oz. 5c, $1 / 4 \mathrm{lb}$. $10 \mathrm{c}, 1 \mathrm{~b} .20 \mathrm{c}, 10 \mathrm{lbs} .15 \mathrm{c}$ per $1 \mathrm{~b}$.

ROUND THICK LEAVED. The best variety for spring seeding; makes thick, dark green, crimpled leaves of finest quality. Very slow in running to seed. Oz. 5c, r/4 1b. 10c, 1b. 20c, 10 lbs. and over $15 \mathrm{c}$ per $1 \mathrm{~b}$.

NORFOLK SAVOY, or BLOOMSDALE. Very early and hardy, with.leaves curled and wrinkled like a Savoy cabbage. Best for fall sowing. Oz. 5c, 1/4 lb. $10 \mathrm{c}, 1 \mathrm{~b} .20 \mathrm{c}, 10 \mathrm{lbs}$. and over $15 \mathrm{c}$ per $1 \mathrm{~b}$.

LONG STANDING. Fine for both fall and spring sowing. Leaves thick and fleshy; will stand long without running to seed. Oz. 5c, I/4 lb. $10 \mathrm{c}, 1 \mathrm{~b} .20 \mathrm{c}, 10 \mathrm{lbs}$. and over $15 \mathrm{c}$ per lb. 
Summer Squash requires $1 \mathrm{oz}$. to 30 hills; winter sorts $1 \mathrm{oz}$. to 15 hills. Three to four lbs. per acre. Plant in May or June.

Culture.-After danger of frost is past, plant in a warm, well pulverized, rich soil, mixing a shovelful or two of well rotted manure with the soil, to the hill. Plant four or six sêeds to the hill, the bush varieties four feet apart, the running sorts eight. When well grown thin out, leaving three of the strongest plants in each hill.

EARLIEST PROLIFIC. The earliest variety of summer squash, somewhat resembling Early Bush, but not quite as scalloped and a little thicker in shape. It is exceedingly productive, 3,600 squashes having been gathered from one thousand vines in a single week. The vines are of true bush form, about two feet high, and of vigorous growth. Pkt. $5 \mathrm{c}$, oz. $10 \mathrm{c}, \mathrm{t} / 4$ 1b. $25 \mathrm{c}, 1 \mathrm{~b} .75 \mathrm{c}$.

EARLY WHITE BUSH, OR PATTY PAN CYMLING. This is more largely grown in the South than any other sort. It is very early, of a light cream color, productive, grows to a good size, and makes a fine shipper. Pkt. 5c, oz. 10 c, $1 / 4$ lb. 20 c, 1 b. 60 c.

Mammoth White Bush. A selection from the Early White Bush, and is larger and more uniform in shape than its parent. It is of a beautiful white color. Pkt. 5c, oz. 10c, $1 / 4$ lb. 20c, 1b. 60c.

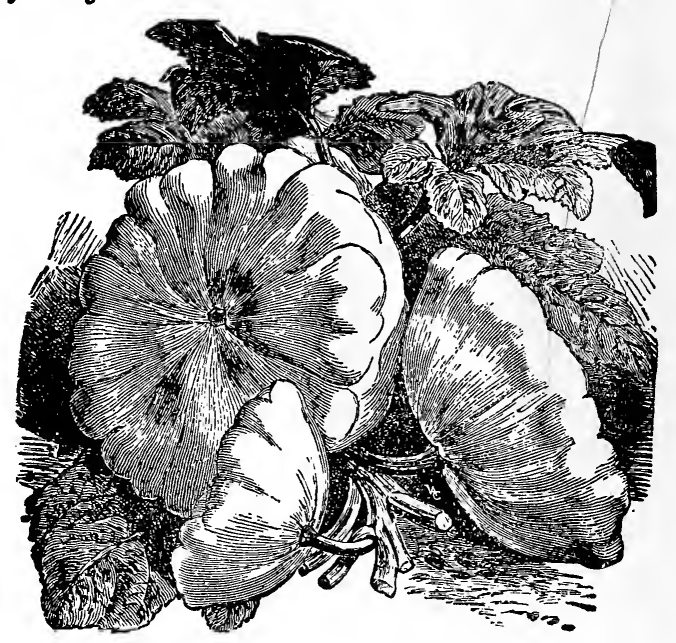

Early White Bush Squash

Golden Summer Crookneck. Early, productive, of a bright yellow color, excellent flavor. Pkt. 5c, oz. $10 \mathrm{c}, \mathrm{z} / 4 \mathrm{lb}$. 20c, 1b. $60 \mathrm{c}$.

Boston Marrow. A standard sort for fall and winter use. The flesh is of a rich orange color and of finest flavor. Pkt. 5c, oz. 10c, 1/4 1b. 20c, 1b. 60c.

Hubbard. A splendid keeping squash, with orange-colored flesh, very dry, and of richest flavor. Pkt. $5 \mathrm{c}$, oz. $10 \mathrm{c}, \mathrm{I} / 4 \mathrm{lb} .25 \mathrm{c}, 1 \mathrm{~b} .75 \mathrm{c}$.

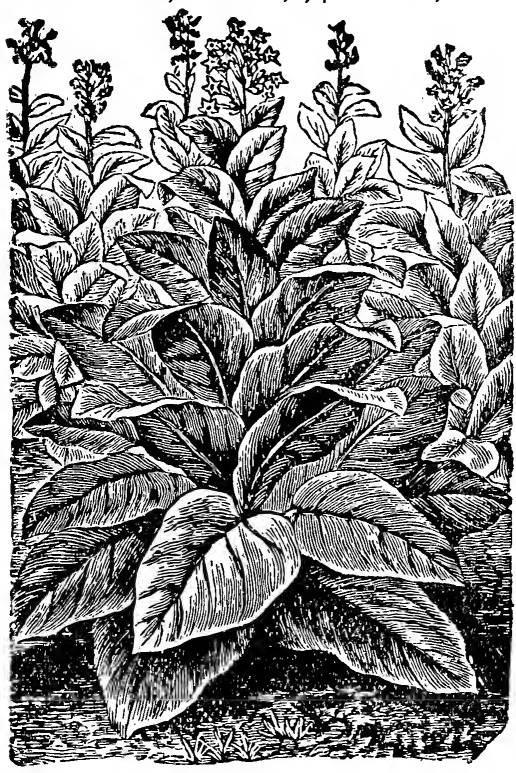

SELECT VARIETIES.

Pkt. 10 c, oz. 25c, $\mathrm{t} / 4$ lb. 85 c, lb. $\$ 2.75$.

Improved Yellow Pryor. Makes fine plug wrappers, cutters, fillers, and smoking tobacco. On rich land yields a heavy crop:

Improved Yellow Oronoko. Fine yellow wrappers and splendid for cutters or smoking.

Kentucky Yellow. A fine, broad-leaf sort, suitable for strips, dark wrappers and fillers. Suitable for rich, alluvial soils.

Broad Leaf Gooch. A good variety for heavy mahogany wrappers as well as bright grades. Best suited to gray or sandy soils.

\section{TOBACCO}

\section{Kentucky's Noted Crop}

Our Tobacco Seed is carefully grown from the best types of the different varieties, is saved from grown shoots

Cnly, and will produce best results.
Culture. Seed is sown in February in a plant bed which is protected with thin cotton cloth. About June 1st set in rich or highlyfertilized ground in rows three and a half

One oz. sows 50 square yards, sufficient to set 2 to 3 acres.

Acme Brand Potato and Tobacco Fertilizer for this crop. one of the best growers in Kentucky, and of greatly improved type. Large, wide leaf, very porous, makes fine plug fillers and wrappers. Suitable for limestone soils.

White Burley. Pkt. 10c, oz. 30c, 4 ozs. $\$ 1.00,1 \mathrm{~b} . \$ 3.00$

Vuelta de Abajo. The finest, silkiest, and most highly flavored Havana. First crop seed carefully grown. Pkt. 10c, oz. 50c, I/4 lb. $\$ 1.75$.

Havana. A strain of Americanized Havana, good for cigars or smoking mixtures. Pkt. $10 \mathrm{c}$, oz. $40 \mathrm{c}, \mathrm{r} / 4 \mathrm{lb}$. $\$ 1.25$.

Connecticut Seed Leaf. A quick maturing, stocky sort, leaves moderate length and of good width. Good for fillers. Pkt. $10 \mathrm{c}$, oz. $25 \mathrm{c}, \mathrm{1} / 4$ lb. $75 \mathrm{c}, \mathrm{b}$. $\$ 2.50$.

STANDARD VARIETIES.

Pkt. 10c, Oz. 25c, I/4 lb. 75c, 1b. $\$ 2.50$.

One Sucker. A dark variety, leaves of fairly good breadth, long, good quality and color. Has few suckers and best suited for alluvial or red clay soils.

Big Oronoko. Broad, long leaf, of fine texture; dark color, good for fillers and strips for sun-cured tobacco.

Sweet Oronoko. One of the best for fillers, smoking, or home-spun twist. It cures a rich red; has a long; narrow leaf.

Bl::e Pryor. A favorite heavy dark tobacco for black strips, wrappers, and fillers. . Broad, long leaves. 


\section{Selected Tomato Seeds}

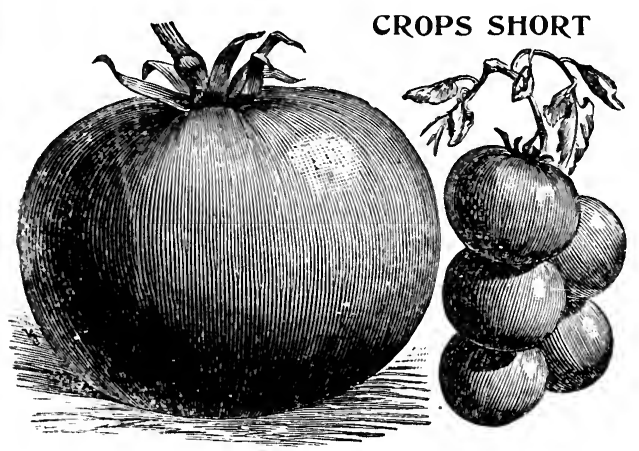

Blue Ribbon Pioneer Tomato

One oz. produces about 2,000 plants, $2 \mathrm{oz}$. enough for an acre. For early crop sow in hot beds in January or February. For late crop in open beds in May.

Culture.-Sow in a hot bed in early spring, or the seed may be sown in shallow boxes and placed in a window when one does not wish to have the trouble of making a hot bed. Transplant to the open ground when all danger of frost is past, setting the plants three or four feet apart each way. Use Acme Brand Blood, Bone and Potash Fertilizer, or well-rotted manure in the hills. Some support should always be provided for the vines to keep the fruit from touching the ground. Fruit may be had several weeks earlier by sowing seed quite early and transplanting to small pots. When these are filled with roots shift to a larger size and transplant to open ground when the weather is warm and settled. As the roots are not disturbed in taking plants from the pots, the plants suffer no check, but grow right on.

Packets, ounces, and $1 / 4$ lbs. mailed free at price. For bulk seed by mail add $8 \mathrm{c}$ per $1 \mathrm{~b}$.

\section{Five of the Best Early Tomatoes}

BLUE RIBBON PIONEER. Without a doubt the best early purplish crimson Tomato offered. It is as early as any of the unshapely extra early sorts, perfectly smooth, symmetrical in shape, and as large as Perfection. The flesh is firm, solid, and of the very finest quality; has very few seeds, and is an excellent variety for shipping or market. The fruits do not crack and rot, as is the case with most of the early sorts, and we strongly recommend it for extended use among growers of early or main crop tomatoes for market. Pkt. 5c, 1/2 oz. 20c, oz. $40 \mathrm{c}, 4 \mathrm{ozs}$. $\$ 1.25$, 1 b. $\$ 4.00$.

JUNE PINK. One of the very earliest and most productive and best pink-fruited varieties in cultivation. The plants are of compact growth, produce more fruits for earliest picking and continue to bear in good quantities throughout the season. We especially recommend it for light, loamy, quick soils for earliest crop. The fruits are smooth, good size and quality. Pkt. 5c, oz. $40 \mathrm{c}$, I $/ 4$ lb. $\$ 1.25$, lb. $\$ 4.00$.

SPARKS' EARLIANA. The fruit is borne in clusters, and so very prolific as to be alone and unequaled in this respect, and combining as it does extreme earliness, very large, uniform size, handsome shape, and beautiful red color, it will be found not only extremely profitable for the grower for market, but one of the finest early varieties for family and garden. It is solid, good size, does not crack, and worthy of extended cultivation everywhere. Pkt. 5c, oz. 30c, $1 / 4$ lb. $85 \mathrm{c}, 1 \mathrm{~b}$. $\$ 3.00$.

CHALK'S EARLY JEWEL. A splendid purplish-red variety, of good size and very popular for market for early crop. Fruits are very attractive in color and shape, not inclined to crack easily, and ripen evenly. Pkt. 5c, oz. 30c, I/4 1b. 85c, lb. $\$ 3.00$.

DWARF CHAMPION. A purplish-red early variety which is very dwarf-growing, and the vines so stiff and upright that they are self-supporting even when laden with fruit. The branches are short, making a bushy plant growing about two feet high. Fruit smooth, medium size, purplishpink color, fairly solid, with no hard core, and of good flavor. Quite popular in this locality because it is particularly suited to very rich land, where other varieties would make too much vine, as they can be planted very much closer than other sorts. Pkt. $5 \mathrm{c}, 0 \mathrm{z}$. $20 \mathrm{c}, \mathrm{I} / 4 \mathrm{lb}$. $65 \mathrm{c}$, 1b. $\$ 2.25$.

\section{VARIETIES FOR MAIN CROP PLANTING.}

BEAUTY. One of the finest tomatoes for general purposes, whether home, garden, or market. The color is purplish-red, very solid, does not crack easily, grows to a large size, and is very productive. It is moderately early. The fruits borne in clusters, very smooth, and of most excellent flavor. A splendid keeper, fine for shipping, and largely used for market as a main crop sort. Pkt. 5c, oz. 20 c, r $/ 4$ lb. 60 c, lb. $\$ 2.00$.

Trucker's Favorite. A large, deep purple variety, producing uniform sized fruit, a little more oblong in shape than Beauty, being very deep from the stem to the bud ends. Largely used for main crop, producing enormous yields of large, smooth, solid fruits. Pkt. $5 \mathrm{c}, \mathrm{Oz}$. $25 \mathrm{c}, \mathrm{1} / 4 \mathrm{lb}$. $75 \mathrm{c}, 1 \mathrm{~b} . \$ 2.50$.

Stone. One of the very best large red tomatoes and one that can be recommended generally for all purposes, whether home use, market, or canning. It is not so early as some other sorts, but is especially desirable for late planting, or where red tomatoes are preferred to purple. As the name indicates, it is very solid and firm; large size, ripens evenly, and is a good keeper. Canners prefer Stone Tomato to almost any sort. Our stock of Stone Tomato is very select. Pkt. 5c, oz. 20c, 1/4 lb. 60c, 1b. $\$ 2.00$.

Acme. This has long been a favorite variety with truckers and growers for market on account of its earliness, good yielding qualities, and generally good appearance. The color is purplishred, flesh fairly solid, with no core, and is a little earlier than Beauty. It has a tendency to crack sometimes after rain, but our stock of Acme is a selected strain, and will be comparatively free of this trouble. Fine for planting under glass, and a standard variety for early shipping. Pkt. 5c, oz. 20c, I/4 lb. 50c, lb. \$1.75. 


\section{TOMATO SEEDS-Continued}

Packets, ounces, and $\mathrm{T} / 4 \mathrm{lbs}$. mailed free. In bulk add $8 \mathrm{c}$ per $\mathrm{lb}$. postage.

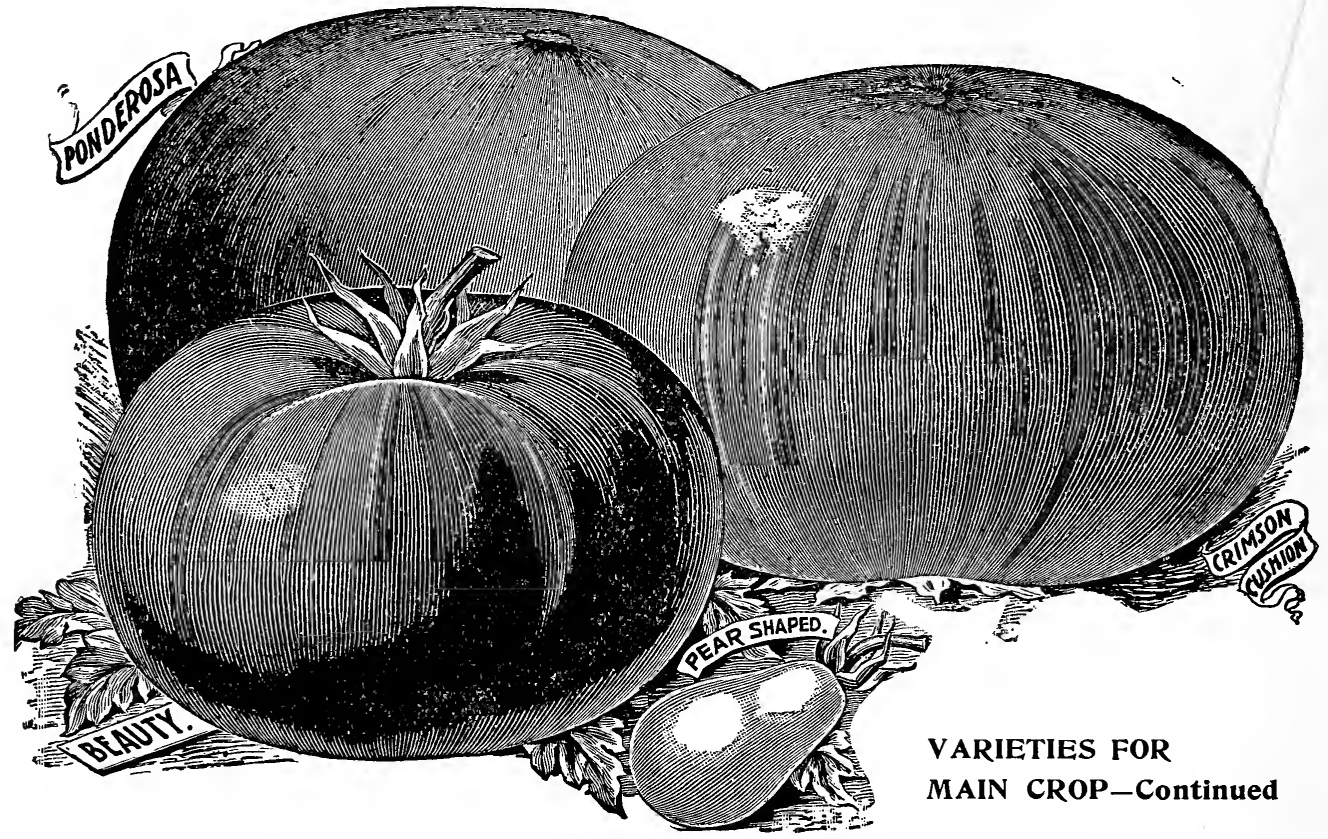

BUCKEYE STATE. Color same as Beauty, being bright purplish-red, but producing larger size fruits. It is not so prolific, but on account of its large size is preferred by many growers. Very desirable for main crop or late planting. Pkt. 5c, oz. 20c, 1/4 1b. 65c, 1b. $\$ 2.25$.

PONDEROSA or 400. Probably the largest of all tomatoes in cultivation, the fruit sometimes growing to such a size that a slice will cover the bottom of a dinner plate. It is inclined to be a little rough, but very solid, and has comparatively very few seeds, and a most excellent sort for private gardens or where very large tomatoes are wanted. Large tomatoes are not as prolific as smaller fruit varieties, and in Ponderosa as well as other sorts of this class, there is a tendency to ripen unevenly. On account of its large size, very thick meaty flesh, and extra fine flavor, it is most desirable for home use or selling on fancy fruit stands, and a fine sort for exhibition purposes at county fairs. Pkt. $5 \mathrm{c}$, oz. $30 \mathrm{c}, 1 / 4 \mathrm{~b}$. $\$ 1.00,1 \mathrm{~b}$. $\$ 3.50$.

CRIMSON CUSHION. Probably the best of the large sorts of bright red color, and one which has been popular for private garden and market wherever grown. While not quite so large as Ponderosa and of different color, it is a little more prolific and especially desirable where red is preferred to the purple variety. It ripens evenly, is smooth in size, of uniform shape and of excellent quality. We consider the Stone a better yielding sort for general purposes, though Crimson Cushion grows larger size. Pkt. 5c, oz. 30c, 1/4 1b. $\$ 1.00,1 \mathrm{~b}$. $\$ 3.50$.

MATCHLESS. A splendid variety for main crop, producing large, red fruits, which ripen evenly and are very solid. It is a great favorite with private gardeners for main crop or late planting. Yields well and of good flavor. Excellent for canning. Pkt. 5c, oz. 20c, 1/4 1b. 60c, $1 \mathrm{~b}$. $\$ 2.00$.

Improved Trophy. One of the first of the modern improved sorts, and one which has been popular for many years. Our strain of this is free from the rough ridges which was objectionable in the old Trophy, but still retains the characteristics which made this sort so popular. The fruits are very large, color rich, deep red, very solid, smooth, and of fine flavor. Pkt. 5c, oz. $20 \mathrm{c}, \mathrm{s} / 4$ lb. $60 \mathrm{c}, 1 \mathrm{~b}$. $\$ 2.00$.

Golden Queen, or Yellow Trophy. The best of the large yellow sorts, resembling the Improved Trophy in growth and shape, but of bright lemon yellow color. It ripens evenly, and is desirable for private use, forming a pretty contrast with the red sorts. Pkt. 5c, oz. 20c, 1/4 1b. 60c, 1b. $\$ 2.00$.

\section{Small Sorts for Preserves and Pickles}

Yellow Pear-Shaped. A popular sort for preserving and pickling, probably the best sort for market for this purpose. Very prolific. Pkt. 5c, oz. 25c, $1 / 41 \mathrm{~b} .75 \mathrm{c}, 1 \mathrm{~b} . \$ 2.50$.

Yellow Plum. Not quite so large in size as Yellow Pear, producing oblong, plum-shaped fruits, ripening evenly, and most desirable for preserving. This is probably the largest yielding of all the small yellow sorts, and by many preferred to the pear-shaped variety. Pkt. 5c, oz. 25c, I/4 1b. $75 \mathrm{c}, 1 \mathrm{~b}$. $\$ 2.50$.

TOMATO PLANTS in Season. Varieties: Dwarf Champion, Beauty, Ponderosa, and other sorts. Transplanted Plants, per doz. 20c to 25c. 100 and 1,000 prices quoted on application. 


\section{Turnip and Ruta=Baga Seeds}

One oz. will sow 400 feet of drill or 360 square feet $(19 \times 19)$. An acre requires $11 / 2$ lbs. in drill, 2 lbs. broadcast. For spring use sow in February or March. For fall and winter, from July to September.

For feeding to stock alone, the use of Turnips should be increased ten times as much as at present.

They cost so little to grow and make such splendid and nutritious feed all through the winter that every farmer should provide a liberal supply for his stock. Our turnip seeds are noted for the fine roots produced.

Culture.-Sow either broadeast or in drills two feet apart, thinning out to six inches, and roll the ground after sowing. Ruta-bagas should be sown in July and early in August and earthed up as they grow. The salad turnips require three pounds per acre.

Ounces of all varieties, except Milan, each $5 \mathrm{c} ; \mathrm{T} / 4 \mathrm{lb} .10 \mathrm{c}$. By mail $12 \mathrm{c}$. postage.

If to be sent by mail add $8 \mathrm{c}$ per $\mathrm{lb}$.

\section{WHITE-FLESHED VARIETIES.}

EARLY RED OR PURPLE TOP (Strap-Leaved). Excellent for table or market. Per lb. $40 \mathrm{c}, 5 \mathrm{lbs}$. and over $35 \mathrm{c}$ per $\mathrm{lb}$.

White Flat Dutch (Strap-Leaved). Similar to Red Top, excepe the top is white. Per 1b. 40c, 5 lbs. and over $35 \mathrm{c}$ per $1 \mathrm{~b}$.

WOOD, STUBBS \& CO.'S IMPROVED RED TOP GLOBE. A greatly improved strain of the old Red Top Globe; small tops, very uniform and handsome roots. Per $1 \mathrm{~b}$. $40 \mathrm{c}, 5$ lbs. and over $35 \mathrm{c}$ per $1 \mathrm{~b}$.

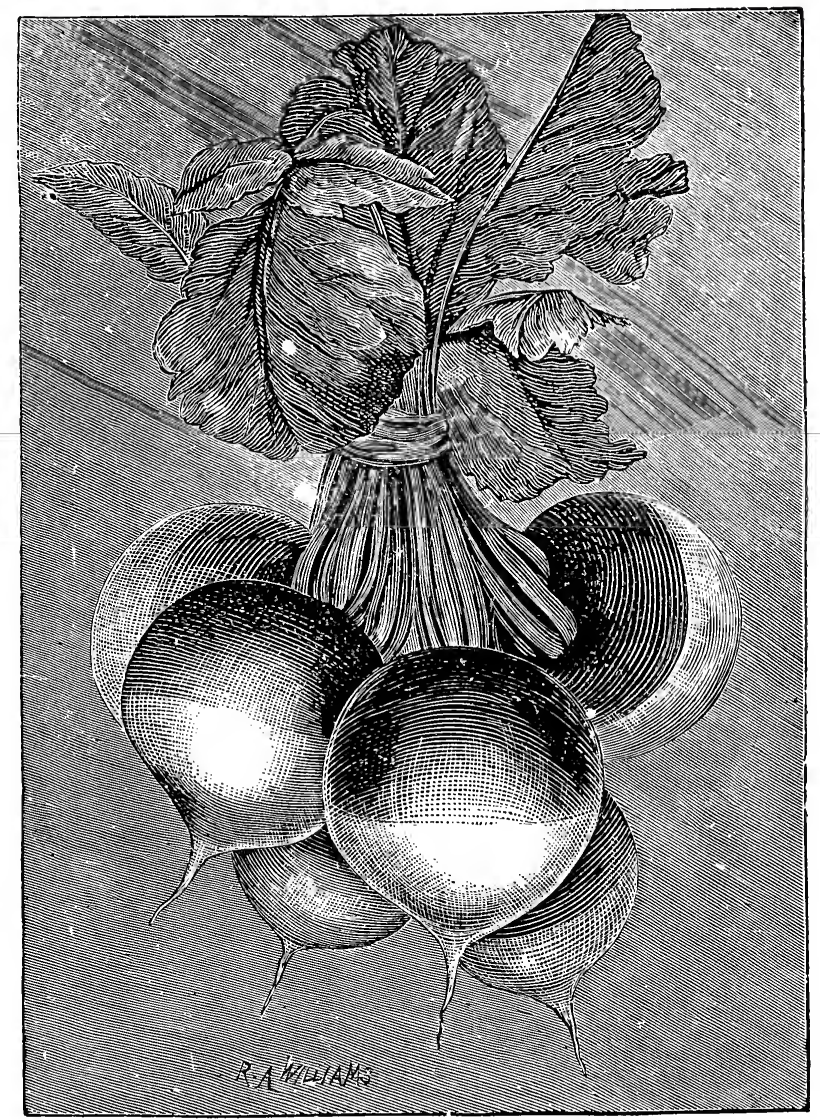

Improved Red Top Globe Turnip

EXTRA EARLY RED TOP MILAN. The Milan Turnips unquestionably surpass any variety of turnips we have ever grown in flavor and table qualities. They are also remarkable for their quickness in growth, and are to be especially recommended as the best of the early turnips, either for the market or private garden. Oz. 10c, I/4 lb. 20c, 1b. $55 \mathrm{c}, 5 \mathrm{lbs}$. and over, $50 \mathrm{c}$ per $1 \mathrm{~b}$.

LARGE WHITE NORFOLK. Largely grown for stock feeding, market, and salad. Lb. $35 \mathrm{c}, 5 \mathrm{lbs}$. and over $30 \mathrm{c}$ per $1 \mathrm{~b}$.

White Egg. A pure white, rapid-growing, egg-shaped sort. Lb. 35c, 5 lbs. and over 30c per lb.

Long White Cowhorn. An excellent white table or stock feeding sort. Lb. 35c, 5 lbs. and over $30 \mathrm{c}$ per lb.

Southern Prize. Fine for stock or winter salad; hardy and needs no protection. Lb. 35c, 5 lbs. and over $30 \mathrm{c}$ per $1 \mathrm{~b}$.

Seven Top. Grown only for winter salad. Very hardy. Lb. 40c, $5 \mathrm{lbs}$. and over 35c per lb.

Purple Top Yellow Aberdeen. A splendid stock feeding sort. Lb. 35c, 5 lbs and over 30c per lb.

Large Amber, or Yellow Globe. Excellent for general crop, stock or market. Lb. $35 \mathrm{c}, 5 \mathrm{lbs}$. and over $30 \mathrm{c}$ per $1 \mathrm{~b}$.

\section{RUTA=BAGA OR SWEDES}

WOOD, STUBBS \& CO.'S IMPROVED AMERICAN PURPLE TOP. For fine qualities and productiveness this can not be too highly recommended. The roots are finer and larger than the ordinary strains of Ruta-bagas; the flesh is rich and sweet. Whether for table use or stock, it has no superior. Per $1 \mathrm{~b}$. $40 \mathrm{c}, 5$ ibs. and over $35 \mathrm{c}$ per $1 \mathrm{~b}$.

Last year I ordered my Tomato Seed from you, and they gave me good results. Since that time the Milan growers have organized an association and elected me as their president. Now, at our last regular meeting a good many growers came to me and wanted to know where I got my last year's seed, and at what price; also variety. BEN F. WOOD, Pres. 


\section{BLUE RIBBON FLOWER SEEDS}

DISCOUNTS ON PACKETS. For 35c worth at packet rates remit 25c: $75 \mathrm{c}$ worth remit 5oc: $\$ 1.75$ worth remit \$1.0o. Prices per ounce and pound are NET, NO DISCOUNT.

Abbreviations and Cultural Information for Flower Seeds.

A-Annual. Lasts one year, producing flowers and seeds the first season. They sometimes come up year after year from self-sown seed. Among these are some of the most beautiful and showy flowers, and a selection of various sorts will give an uninterrupted succession and gorgeous display from early summer till frost.

B-Biennial. Lasts two years. Generally blooms the second season.

P-Perennial. Lasts three or more years, usually blooming the second season and continuing for years.

ت्Z-Hardy. Hardy annuals (H. A.) can be sown in open borders in March or Ápril, thinning out or open borders in March or April, thinning out or (H. B.) and Perennials (H. P.) can also be sown at this time or later in the summer or fall. Started in the fall or very early in the spring they usually bloom the first season.

Ageratum Profuse blooming plants, Pkt.

H. H.-Half-Fardy Annuals (H. H. A.), Biennials (H. H. B.), and Perennials (H. H. P.) require a rather longer time to establish themselves, and to bloom early, be started in the house or hotbed. Out of doors they can be sown in the latter part of April or first of May. Most H. H. B. and H. H. P. started in the house bloom the first season.

T-Tender Annuals (T. A.), Biennials (T. B.) or Perennials (T. P.) require about the same treatment as H. H. Annuals, with more caution as to exposure, keeping in pots longer, and removing outside only when the weather is settled and warm.

Figures 1, 2, 3 are indicative of the seasons at which the plants usually bloom, viz: 1, early in the summer; 2, about mid-summer; 3, late in the summer and fall. Where the blooming season extends, two figures are used, viz: 1-3, means from early in the summer till fall.

blooms the whole summer. Excellent for cut flowers and fine for large beds in summer and flowers and fine for large beds in summer and as pot plant

Mexicanum. Light blue. Per oz. $30 \mathrm{c} \ldots \ldots \ldots$.......

Alyssum Well known free flowering, edgings, or winter blooming. H. A.-1-3.

Sweet Alyssum. White, blooms in clusters. Oz.

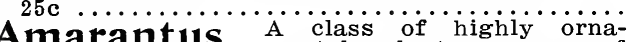

Amarantus A class of highly ornawhich are grown exclusively for their handsome foliage, while others are equally desirasome foliage, while others are equally desirable for their beautiful clusters of brilliantcolored flowers, which are very effective for in rather poor soil. H. H. A.- $2-3$.

Caudatus. (Iove Joies Bleeding.) Long, drooping sprays of red flowers. Per oz. 20c.....

5

Antirrhinum (snap Dragon.) w $\mathrm{e}$ i bnown, showy, and useful flowers of a great variety of brilliant and handsome colors. Very effective in beds, succeeding in any good garden soil. Height 2 to

Blooms the first season.

Picturatum. Blotched and spotted, dwarf grow-

ing, mixed colors. Per oz. 40c.............

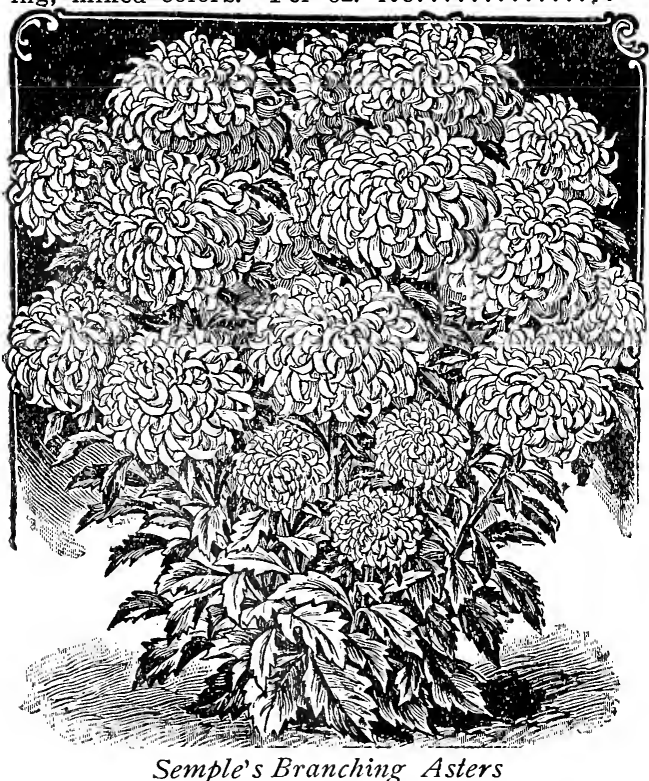

Aquilegia (Columbine.) Useful early sum(c) mer-blooming plants bearing odd and peculiar-shaped flowers. They grow feet, and bearing fifty to eighty blossoms of feet, and bearing fifty to eighty blossoms of

Double. Mixed colors. Per oz. 25c........

Superb Asters Beautiful and popular beds, being in bloom when most other plants are nearly over. Very useful for cut flowers and bouquets. H. H. A.-2-3.

SEMPIF'S BRANCHING ASTFRS. A beautiful strain of late flowering Aster, which bears on long stems perfectly formed double flowers 4 inches in diameter. 18 inches to 2 feet high.

Irixed Colors. $1 / 4$ oz. $35 \mathrm{c}$, oz. $\$ 1.00 \ldots \ldots \ldots \ldots \ldots$

VICTORIA ASTERS. For size, color, and profusion of bloom this is probably the handsomest of all Asters. The colors include many delicate and some gorgeous shades; flowers double and 4 inches across, and 20 to 30 blooms to a single plant. 15 to 18 inches high.

All Colors Mixed. Per oz. $\$ 2.00,1 / 8$ oz. $40 \mathrm{c} . \ldots$

PEONY FIOWFRED PEREFTION ASTERS. A splendid strain bearing large double flowers of perfect form. Splendid for bedding. Height 18 inches.

Mixed Colors. Per oz. $\$ 1.25,1 / 8$ oz. $35 \mathrm{c} \ldots \ldots \ldots \ldots$

GFRMAN QUIIIFD. (China Aster.) Many choice Mixed. All the best colors. Oz. $40 \mathrm{c} \ldots$
Pkt. 


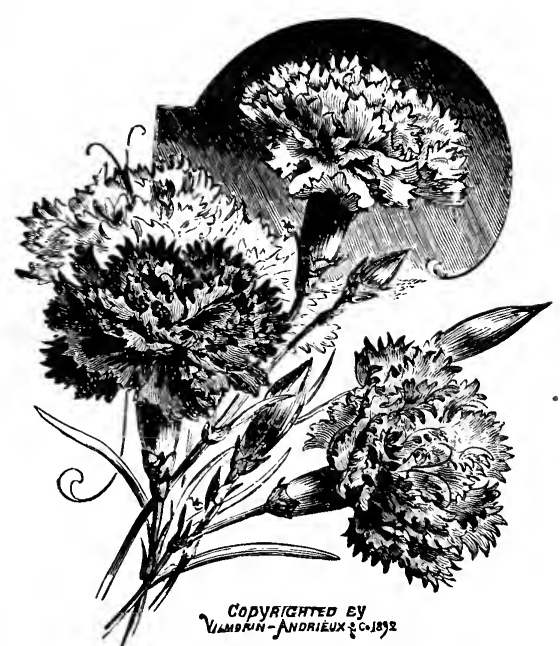

Marguerite Carnations Balsam (Touch Me Not, or Iady slipper,) masses of beautiful, brilliant-colored flowers in the greatest profusion. Rich soil is required for the prest blooms. H. H. A.-2-3. Calendula Showy free-flowering annuals ducing a fine effect in beds or mixed borders and bloom until frost. H. A.-2-3. Height 1 foot.

Mixed Colors. Yellow and orange. Oz. 20c... Calliopsis or Coreopsis $\mathrm{B}$ e a t i ful mer bedding annuals, with large, bright flowers of golden yellow varied with rich brown. ers of golden yellow varied with rich brown. Excellent for cutting

2 feet. H. A. $-2-3$. Ianceolata. Beautiful golden yellow perennial; unexcelled for borders; excellent for cutting. Oz. 75c ... Popular favorites, flowering andytuft profusely the whole summer. Very valuable for edgings and borders, fairly very valuable for edgings and borders, fairly covered with masses

Fmpress. A fine variety, bearing large trusses, pure white, fine for cutting or bedding. Oz.

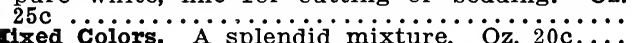

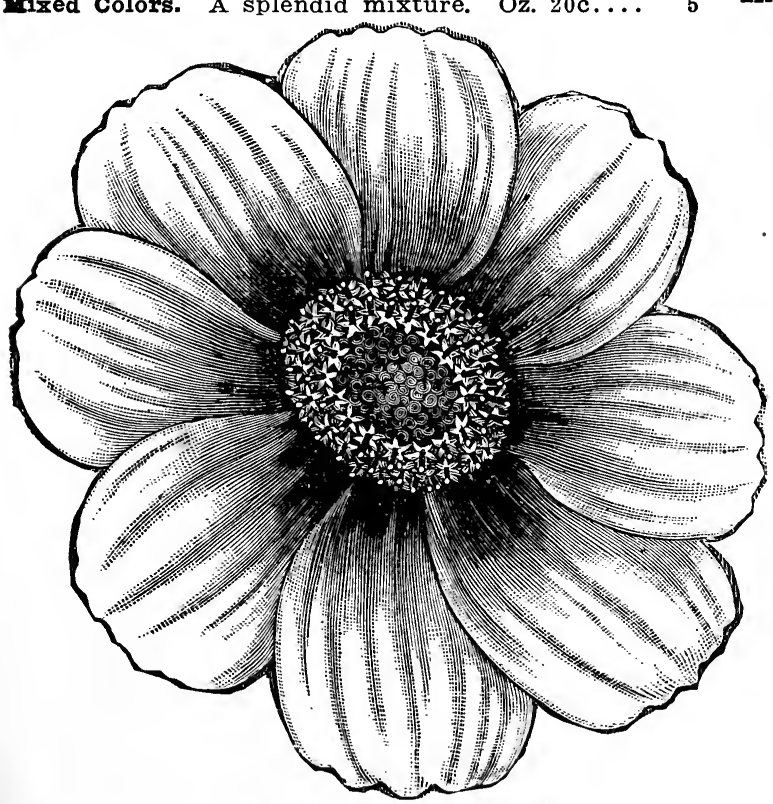

Mammoth Perfection Cosmos

\section{CARNATIONS}

General favorites for their delicious clove fragrance and diversity of color. Excellent bloomers in the garden or for winter flowering. H. H. P.-1-2. Height 1 to 2 feet.

Note.-To extend the life of carnation plants, keep blooms picked off.

Marguerite. Blooms four months after sowing. Flowers profusely. Colors range through vari-

Flowers profusely. Colors range through varimixed Colors. (German.) Oz. $\$ 1.00 \ldots \ldots \ldots \ldots$. Canterbury Bells (Campanula.) Po... hardy plants, bearing a great profusion of at tractive bell-shaped flowers. Colors rose, blue, white, etc. H. D.- $1-2$. Height $2 \frac{1 / 2}{2}$ feet.

single Mixed. Oz. $30 \mathrm{c} \ldots . . . . . . .$.

Celosia or Cockscomb Very showy ing large, ornamental, comb-like heads of various colors; excellent for beds or pot plants. H. A. - 1-3.

Glasgow Prize. Dark foliage, immense showy dark crimson comb. One foot...............

5 Centaurea Gymnocarpa. (Dusty miller.) Height $11 / 2$ feet. Silver foliage, delicately cut. f beds, etc. 522 Excellent for vase or edgings CFNTAURzA CYANUS. Corn Flower-Ragged

Robin. H. A.-1-2. A beautiful strain of the popular Corn Flower, comprising lovely shades of blue, rose, purple, and white flowers. Excellent for cutting.

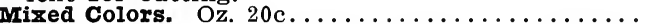

Coleus Popular foliage plants for bedding, Although perennials, they will attain perfection the first season from seed sown early in the house.

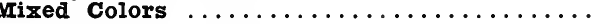

Cosmos Cosmos are of easy culture, for cutting and are almost indispensable for cutting and garden decorations, their lovely blossoms being produced in greatest profusion after most other flowers have
succumbed to frost. H. A. Height 4 to 6 feet.

FARIY FIOWFRING. This is a very desirable sort, which begins to bloom early in July, gradually increasing in number of flowers until the plant is a mass of bloom, and continuing till frost. The individual and continuing till frost. The individual fection.

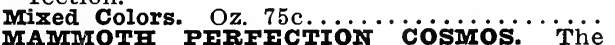
MAMMOTH PFRFECTION COSMOS. The flowers are double the size of the old, large flowering Cosmos, measuring from three to four inches across. The petals are large, overlapping, forming perfectly round flowers, deeply ribbed, and of good substance.

Mixed Colors. Oz. 4 (P. Delphinium (P eren nial iarkspur.) with beautiful graceful spikes of flowers of many exquisite shades. They are invaluable for permanent beds and borders, or in the corners or edges of the garden. Sow in the bloom in the succeeding summer. H. P.-2-3. Elatum Frbridum, mixed colors; very showy.

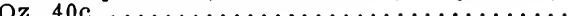




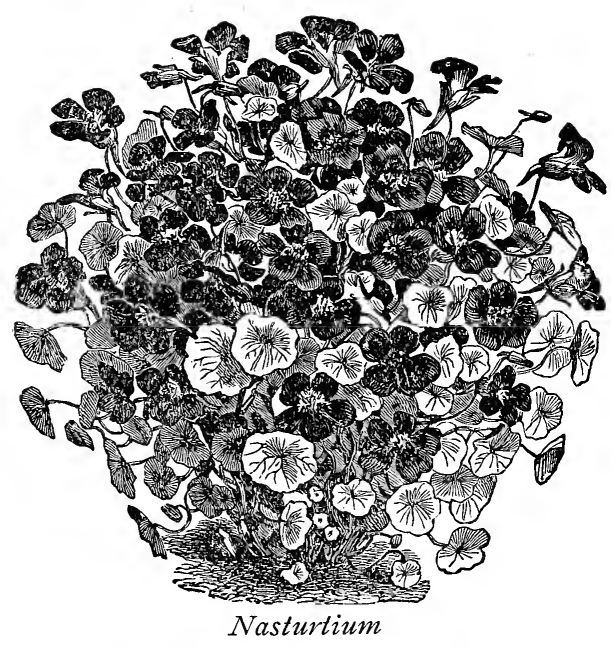

Dianthus, or Pinks

Chinensis fl. pl. Double China or Indian Pink Our mixture of this strain is extra fine, and contains a large variety of colors. Oz. 30c.... ers are large and of the brightest colors. Mixed

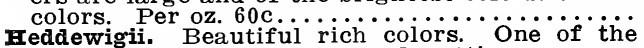

finest annuals for show and cutting. Eschscholtzia (California Poppy.) ing plants for bedding. Flowers are of extremely rich and beautiful colors. Height 1 foot $H$. A. - 1-3.

Mixed colors. Per oz. 20c (iviosotis.) Populä; Forget=me=not charming little plants, bearing delicate blue flowers. H. H. P.-1-2. Alpestris. A dwarf blue free-flowering sort. Oz.

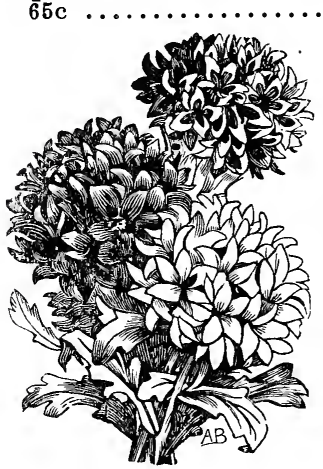

Gaillardia
Gaillardia

Desirable' b e d d in g plants and excellent for cutting. Flowers are of brilliant and showy colorings. H. A.-1-3.

Mixed Colors. The most varied colors. Oz.

\section{Globe Amaranth}

(Bachelor's Buttons.) Well-known popular everlastings, whic h form bushy plants about two feet high, and bearing someflowers. Excellent as border plants, and very useful for winter decoration. $\mathbf{H}$. $\mathbf{H}$. $-2-3$.

Mixed Colors, white, purple, striped, etc. Oz. 25c Heliotrope Well-known deliciously frading or pot culture. They can be raised from ding or pot culture. They can be raised from seed easily, bloomin

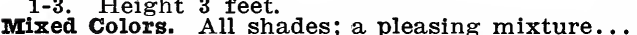
Iemoine's Giant. A new strain, bearing immense Hollyhock Stately and showy earlygreat variety of colors. Perfectly hardy, and blooming year after year when once planted. H. P. Sow in May or June.

Double, irixed Colors. Per oz. $75 \mathrm{c} . . . \ldots \ldots \ldots$

Lobelia Profuse blooming little plants, of baskets, or vases. value for edgings, hanging year. Should be started in boxes.

Crystal Palace. Dark blue. Fine.,ioci... Marvel of Peru (nown and popular flowers; open only in the evening or on cloudy days. H. H. B. Blooms first season.

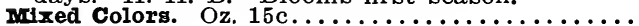

Marigold Easily grown and useful garden growing, and most striking African are tall the French varieties are dwarf and best, wapted to small beds, or as a foreground to taller plants. H - 2-5. as a foreground to taller French Gold Striped. Rich maroon, striped with golden yellow. Very free flowering. Oz. 40c. mldorado. Colors from pale yellow to deepest Miononette A universal favorite on acgrance. Good for count of its delicate fraat intervals throughout the summer for a succession.

Machet. Bears massive spikes of very fragrant

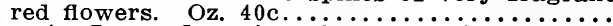

Sweet. Large flowering; fragrant. Oz. $20 \mathrm{c} . \ldots$.

\section{NASTURTIUM}

TALL SORTS

Iarge Dark Crimson. Showy flowers. Oz. 15c..

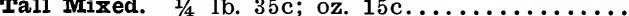

DWARF, or TOM THUMB VARIETISS

Impress of India. Has dark tinted foliage, while the flowers are of the most brilliant crimson

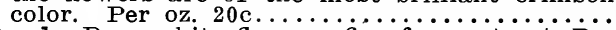
Pearl. Pure white flowers, fine for contrast. Per Golden King. Golden yellow flowers. Per oz $\ddot{2} \dot{0} \dot{c}$ King of Tom Thumbs. Scarlet; dark foliage.

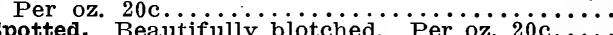
Sose. Soft pink. very distinct. Per oz $20 \mathrm{c} \ldots$ Dwarf Mized. $1 / 4$ lb. $35 \mathrm{c}$; oz. $15 \mathrm{c} \ldots \ldots \ldots \ldots \ldots$

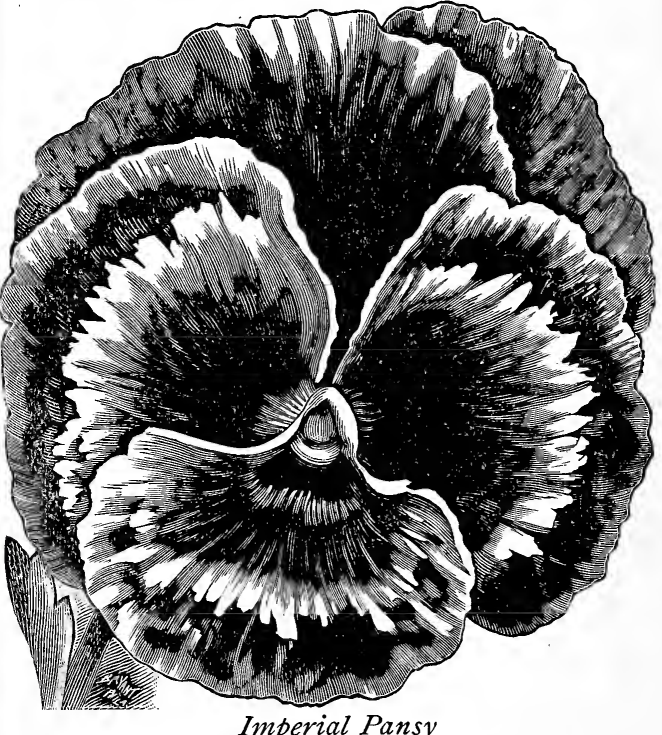

Pansies Our Pansy seeds are saved from plants selected for the beauty and For best results sow in rich soil in a sheltered location, and water freely. Seeds sown early in the spring will produce blooms in the summer, but not as large as if sown in the fall.

wood, Stubbs \& Co.'s Imperial. This strain is unexcelled for its varied and beautiful colors. $1 / 4$ oz. $\$ 1.00$, oz. $\$ 6.00 \ldots \ldots \ldots \ldots \ldots \ldots \ldots \ldots \ldots \ldots$

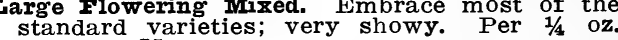
$25 \mathrm{c}$; oz. $75 \mathrm{c} \ldots \ldots \ldots \ldots \ldots \ldots \ldots \ldots \ldots \ldots \ldots$ blants $\ldots \ldots$ for

Petunia Une of the best plants large, of brilliant colors, and borne in great profusion H. H. A.-2-3. Height $11 / 2$ to 2 feet.

mixed Colors. A choice mixture, including many

large flowering sorts. $1 / 4 \mathrm{oz} .25 \mathrm{c}, \mathrm{oz} .75 \mathrm{c} . \ldots$.

Phlox Drummondii One of the prettiular of garden annuals. Makes very attractive beds, and continues in bloom throughout the
summer. Sow in April in open ground, or can be started earlier indoors.

Star and Fringed. Dwarf growing varieties, bearing brilliant fringed and star-shaped flowers. Exceedingly pretty. Mixed colors..... Iarge Flowering Irixed. Fine colors and shad- 
Poppies Hardly any class of plants afford showy display. Very easy culture, the seed being sown where they are to bloom.

\section{PERENNIAL POPPIES H. P.}

Oriental. One of the grandest of all Poppies. A rich dark glowing crimson, the foliage very celand dark green. Magnificent................. satin, and plants will continue to flower for three or four years after sown. Mixed colors.

\section{SINGLE ANNUAL POPPIES}

Tulip. Large, bright scarlet flowers, which are so dazzling in appearance as to remind one of a bed of scarlet Tulips ........................... flowering and remarkably brilliant colors from pale rose to deep crimson. Delicately edged and fringed. Mixed colors. Per oz. $40 \mathrm{c} . . .$. .

\section{DOUBLE ANNUAL POPPIES}

Cardinal. The plants grow about 18 inches high, bearing large, very double flowers, of glowing scarlet, a striking contrast with the deeply

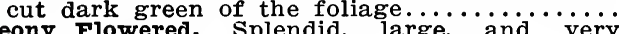
double flowers in finest mixed colors. Per

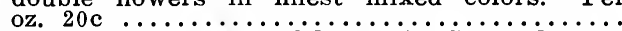

Portulaca (ivoss siowers.) succed best duces flowers of almost every color in the greatest profusion. The double is especially beautiful and showy. T. A.-2-3. Height 6 inches

Single Mixed. Per oz. 40c........................

Ricinus (castor oil Plant.) Luxuriant, palm-like leaves. Excellent for background palm-like leaves. Excellent for background

zanzibariensis. Bears gigantic leaves, 2 to $21 / 4$ feet across, of various colors, green, ' coppery brown, purple, bronze, etc., and the stems from pale green to various shades of red. Exceedingly handsome. All colors. Per oz. 20c..... Mixed varieties. A mixture of the best sorts. Per oz. 15c. Briliant fiowers are borne in pro-

Salvia Brilliant flowers are borne in proExcellent for cutting. Seed sown early in the house produces better plants than from cuttings. H. H. P.-1-3. Height 3 feet.

splendens. (Scarlet Sage.) The brilliant scarlet variety so well known. Per $1 / 4$ oz. $50 \mathrm{c} ;$ oz

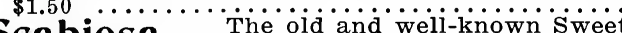

Scabiosa Scabious is not cultivated as much as it deserves. They bear large, perfectly double flowers of many beautiful colors, on long, and are excellent for cut long, graceful stems, and are excellent for cutSCARIIT SAGE. See Salvia Splendens.

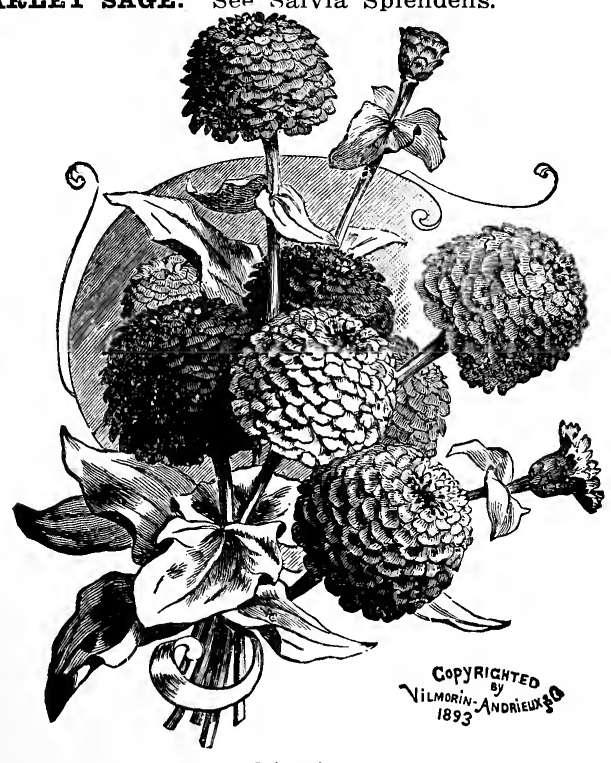

Zinnias

Ten Weeks Stock (Gilliflower.) DePkt. ding or pot culture. They bear an immense quantity of fragrant blooms, each plant forming a perfect bouquet, and are splendid for cutting. H. H. A. -1-2

10 10

Sweet William a beautiful class of plants of extreme richness and diversity of color. Produces a fine effect in beds or mixed flower borders. H. B.- $2-3$.

Single and Double Mixed. Many bright colors.

Sunflower Luxuriant growing plants for centers of beds or backgrounds for other plants. H A-2-3.

"Stella." A miniature Sunflower covered with hundreds of small, bright orange, single flowers. Of dwarf pyramidal growth. Fine for bedding and cutting. Oz. $50 \mathrm{c} \ldots \ldots \ldots \ldots \ldots \ldots$ variety, growing 3 to 5 feet high. Per oz. 20c........ 5 10 5

Verl

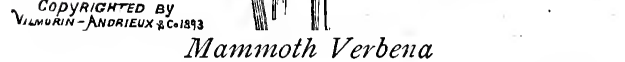

Verbena splendid for beds or massing. blooming from early summer till late in the fall. Verbenas grown from seed are always thrifty and do not rust. Sow early in house, or out of doors in April. H. H. P.-1-3.

New Irammoth. This strain produces blooms of largest size and most brilliant colors. The trusses are uniform, bearing unusually large flowers in a wide range of colors. Per $1 / 4 \mathrm{oz}$.

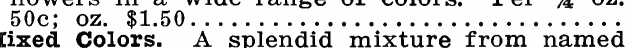

Mixed Colors. A splendid mixture from named
sorts, comprising rich, beautiful colors. $1 / 4 \mathrm{oz}$. sorts, comprising rich, beautiful colors. 1/4 oz.

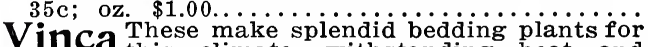
inca this climate, withstanding heat and drought when other plants suffer. The foliage is very distinct, being of dark rich, glossy green, and the plants bear large pink and white single

Mixed Colors. Per $1 / 4$ oz. $25 \mathrm{c}$; oz. $85 \mathrm{c} \ldots \ldots \ldots \ldots$

vIOIFTS. Favorite little plants, producing flowers of most delightful fragrance; popular with every one. Sow seed in March or April in beds and transplant

Mixed Colors. Sweet scented.................... producing fragrant flowers of various colors. Blooms early in the season. H. P.-1.

Single Mrixed. Oz. 35c...................... For Zinnias for gorgeous summer and The flowers are perfectly double, resembling The flowers are perfectly double, resembling Dahlias, and almost every shade of color. For suitable. H. A.- $2-3$.

Iarge Flowering Doubie Mixed. Oz. $40 \mathrm{c} \ldots \ldots \ldots$ 


\section{SWEET PEAS}

Plant early in February, weather permitting, in a situation not too sunny, putting the seed 3 to 4 inches deep to insure good roots. Sowings may also be made in October, givIng the plants slight protection during the winter.

\section{Sweet Pea Mixtures}

WOOD, STUBBS \& co.'s SPECIAI MIXED. An unsurpassed mixture, combining every shade and type. It is made up of named sorts only, all choice, large-flowering sorts, the colors beIng distributed as evenly as possible throughout. For diversity of color, size of flowers and beautiful forms, this mixture is unexcelled.

Oz. 5c.; I=4 lb. I 5c.; lb. $40 c$.

Postage Se lb. extra

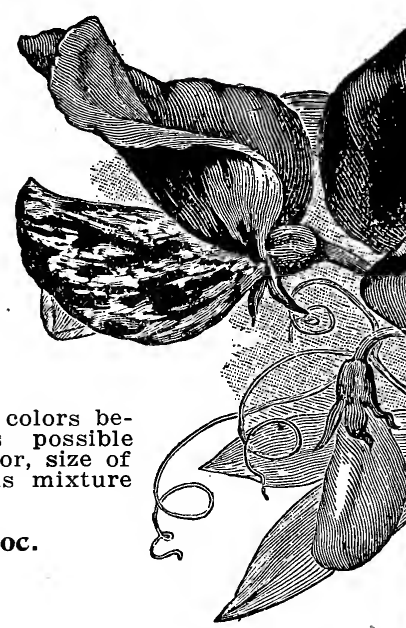

MIXED SWEFT PEAS. A good mixture of older varieties containing all colors.

$I=4 \mathrm{lb}$. 1 oc.; lb. 3oc.

Postage $8 \mathrm{c} \mathrm{lb}$. extra.

\section{Thirty=two Superb Sweet Peas, Including all Shades.}

\section{SPECIAL LOW PRICES}

\section{Price, all Varieties, oz. 5c.; I=4 lb. I5c.; lb. $40 \mathrm{c}$.}

If by mail add 2c. for 4 oz.; $8 \mathrm{c}$. per lb.

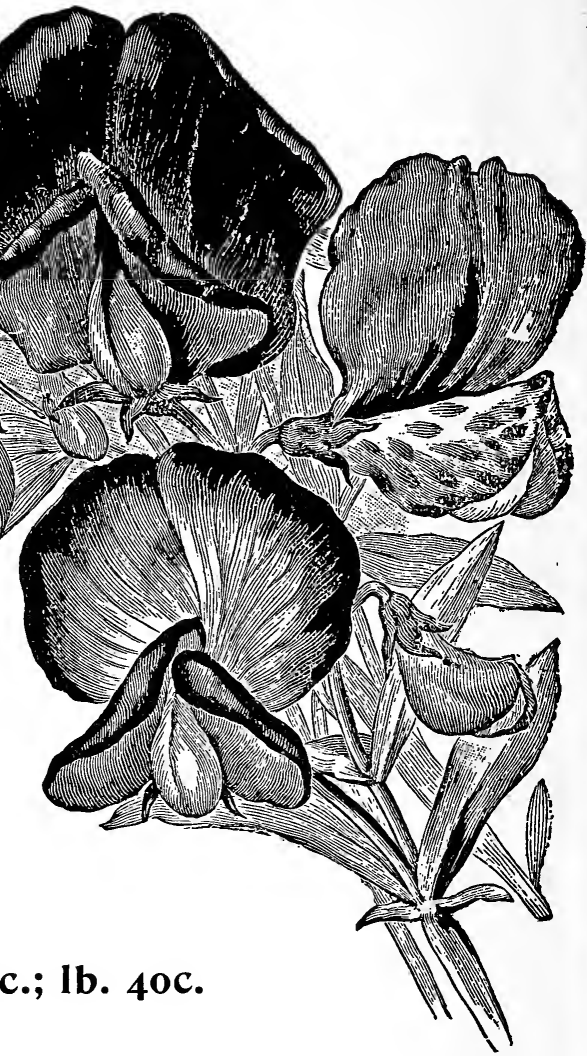

Colors:

Colors:

Crimson on White-Mikado. Distinctly striped, crimson on white ground.

pand che Burpee. Pure white, of largest expanded form and great substance. Free-flower-

Emily Henderson. Fine white; not quite so lar. as the above, but a little earlier. Robust growth Sadie Burpee. Flowers of very largest size and purest snowy white. Ohe of the finest of all

Speckled. Gray Friar. Very distinct in color and markings; general effect is gray, with flne speckled variegations, which are very odd and effective. A good grower and abundant bloomer.

Aurora. Flowers very large and of expanded form three on a stem. Ground silvery white, beautithree on a stem. Ground silvery white,

Light Yellow-Golden Gleam. Deep primrose yellow as large as Blanche Burpee, elegant form and substance, very free-flowering.

Mrs. Eckford. A large, perfectly-formed flower of beautifully shaded primrose yellow.

Queen victoria. Soft primrose yellow, slightly overlaid with faint purple. Flowers very large, erect, slightly pointed, with edges flnely recurved.

White and Pink-Triumph Large size, grand flowers, and most beautiful coloring. Color white, suffused with salmon pink and tinted with carmine at the base. Wings delicately veined with carmine.

Rose Pink-Katherine Tracy. Splendid large, open flower, good substance and color, a vigorous grower and free bloomer.

venus. Rich delicate blending of rose, salmon, and buff; flowers medium size and finely formed.

vigorous grower; blooming abundantly. ite, with Red and Rose Standards-Blanche Ferry. Deep pink stand

profuse bloomer. above, being the earliest variety grown. Dwarf, compact habit, free-flowering.

Deep Pink-Prima Donna. A large, perfect flower, of elegantly hooded form and finely proportioned stems of three to four flowers.

Pink, White Striped-Mrs. Joseph Chamberlain. Flowers enormous, three to four on a stem. White ground, heavily striped and flaked with bright rose. Excellent sort and very profuse bloomer.
Tricolor-Columbia ty, standards crimson rose striped on white ground, wings pale blue striped on white ground. Should be in every collection. lightly suffused with lilac; the edges of both standards and wings are a clear heliotrope blue.

Lavender or Mauve-Celestial. Delicate lavender blue, wings silvery lavender. Finely-formed hsell-formed flowers. The best of this color.

Countess of Radnor. Bluish mauve shading to reddish tinge; vigorous in growth.

Now Countess. Similar to Countess of Radnor, but without the reddish tinge. Flowers large and of the finest form and delicate lavender.

Heliotrope-Fmily Fckford. Superb large flowers, standards rosy heliotrope, wings blue. The flowers assume darker shade with age.

Blue-Navy Blue. The richest and most distinct shade of blues. Vines vigorous and very productive.

Captain of the Blues. Standard purplish blue, wings light blue Large expanded flowers, and the nearest approach to a true blue.

Rosy Carmine-Fer Majesty. Large bold flowers of a most beautiful bright rosy carmine color.

Orange Rose-Irady Penzance. A beauty. Standard deep bright orange-tinted rose; wings deeper rosy carmine; a larger flower.

Scarlet-Mars. One of the best and largest scarlet flowers of good substance and free-flowering.

Firefly. The richest and best of all scarlets. Bold, expanded flowers.

Salopian. Beautiful, rich, deep-glowing crimson, tinged with orange-salmon. Flowers large grandiflora form.

Striped, Purple, Brown, and White-Senator. Splendid, finely formed large flowers. White ground, heavily striped with chocolate, purple, and bright brown. Very striking.

Purple-Monarch. Standard maroon purple, tinged with indigo; wings velvety purple.

Maroon-stanley. Rich, dark maroon, of fine form and extra large flow
White and Lilac-Iottie Eckford. White ground, 
Balloon Vine (Irove in a Puff.) Very pretty and rapid-growing inflated seed pod shaped like a tas small, white flowers, produced in abundance, which makes it very attractive.

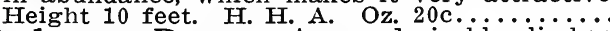

Balsam Pear A very desirable climber pear-shaped yellow fruit, the flesh of which, when kept in whisky or alcohol, makes a most effective pain-killer and healer of cuts, bruises, Cobaa Scandens one of the finest of with fine foliage and large, bell-shaped purple ing a height of 20 to 30 reet aly, often attaincorrespondingly. edgewise and cover lightly. Start in house and transplant in May. H. H. P....... One of the $\mathrm{p}_{\mathrm{i}} \mathrm{\textrm {i }} \mathrm{\textrm {s } t}$ Cypress Vine One of the prettiest To secure the best results sow the seed thickly so as to make a thick growth. Sow middle of April. Height 10 feet.

Mixed Colors. White and scarlet. Oz. $25 \mathrm{c} . . . .$. ers of rapid growth, bearing 作 which are followed by bright purple pods. Oz.

\section{Gourds}

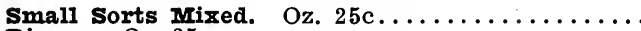

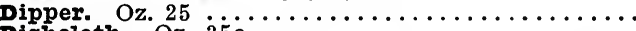

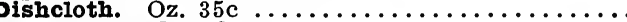

Sugar Trough. Oz. $25 \mathrm{c} \ldots \ldots \ldots \ldots \ldots \ldots \ldots \ldots$ etc. Height 10 feet. H. H. A. Oz. $40 \mathrm{c} . . . . .$. withers. It grows very rapidly often attain Dolichos (Fyacinth Bean.) Annual climb-

Pkt.

\section{SUMMER FLOWERING BULBS AND ROOTS}

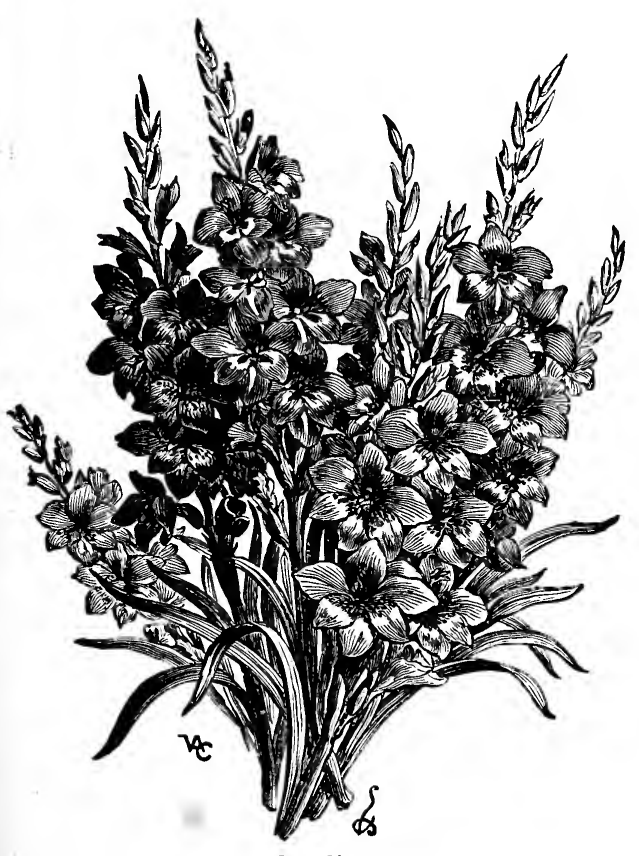

Gladiolus

\section{Morning Glories}

Imperial Japanese Morning Glory. One of the grandest of all climbers. They are all shades, from pink to the most brilliant crimson and maroon; blue, from pale lavender to royal purple; also white, yellow, bronze, striped, siotched, and spotted. Sow in a warm, sunny situation, in good, rich soil, giving plenty of

Brazilian Morning Glory. (Impomea setosa.) A very vigorous and luxuriant annual. The vines grow 30 to 40 feet high. The flowers are from 3 to 4 inches across, and of a beautiful rose color. The plant is covered with short reddish hairs, which, with its immense leaves and large clusters of curious seed pods, render it very ornamental and of tropical aspect. T. P.......

Convolvulus Major. (Morning Glory.) Mixed

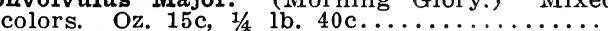

\section{Evening Glory or Moonflower}

Beautiful rapid climbers, bearing large, white the house and transplant when the weather is warm. Before planting it is best to file a small hole in one end through the outer hull and soak for thirty-six hours in warm water.

Impomea Hybrida. This has all the luxuriance of the original Moonflower, and blooms quite tage of blooming much earlier. Vines grow

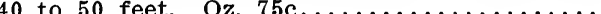
flowers, 4 to 6 inches in diameter, which open in the evening and on cloudy days. Start in as abundantly, but it has the further advan-

\section{Caladium Esculentum (Elephant's Ears)}

Caladiums are among the most striking of the ornamental foliage plants either for pot or lawn planting, of easy culture, and can be grown in any good garden soil. A full-grown plant will stand about 5 feet high. During the winter the roots should be packed away in dry sand.

Extra Large Bulbs 15c each, $\$ 1.50$ per doz. First Size Bulbs $10 \mathrm{c}$ each, $\$ 1.00$ per doz. If to be sent by mail add $8 \mathrm{c}$ each extra for postage.

\section{Gladiolus One of the most attractive of all sum-} mer flowering bulbs. Excellent for mixed bulbs, but more gorgeous effects may be had by massing in large clumps. For a succession of bloom throughout the summer, plant at intervals from April to June.

If by mail add $10 \mathrm{c}$ per doz. for postage.

Each Per doz. Per 100

Scarlet and Crimson_._._._._\$0 $04 \quad \$ 025 \quad \$ 150$

White and Light $-04 \quad 30 \quad 225$

Pink Shades _-_._-_._-_.- $04 \quad 25 \quad 175$

Striped and Variegated.-.-.- $04 \quad 35 \quad 250$

Yellow -

Superfine Mixed -

All Colors Mixed, 3 for $10 \mathrm{c}$

Maderia Vine Roots On account of its very rapid growth and thick

shade it affords, this is one of the most popular climbers. Will run twenty feet or more.

5c each, 25c per doz., $\$ 1.75$ per 100 . If by mail add $10 \mathrm{c}$ per doz. for postage.

Tuberose Bulbs Tuberoses prefer a strong, rich, warm soil. If by mail add 10 c per doz.

EXCELSIOR PEARL. A short, robust variety producing immense spikes of perfectly double flowers. As we handle immense quantities of these we are able to make prices low.

Large Bulbs. 5c each, 25c doz., $\$ 1.50$ per 100. Second Size Bulbs. 2 for 5c, 20c per doz., $\$ 1.00$ per 100.

OUR CATALOGUE OF BULBS for Fall Planting, giving descriptions, methods of planting, etc., of Hyacinths, Tulips, Crocus, Narcissus, etc., is ready in August. If you desire a copy kindly write us now. 


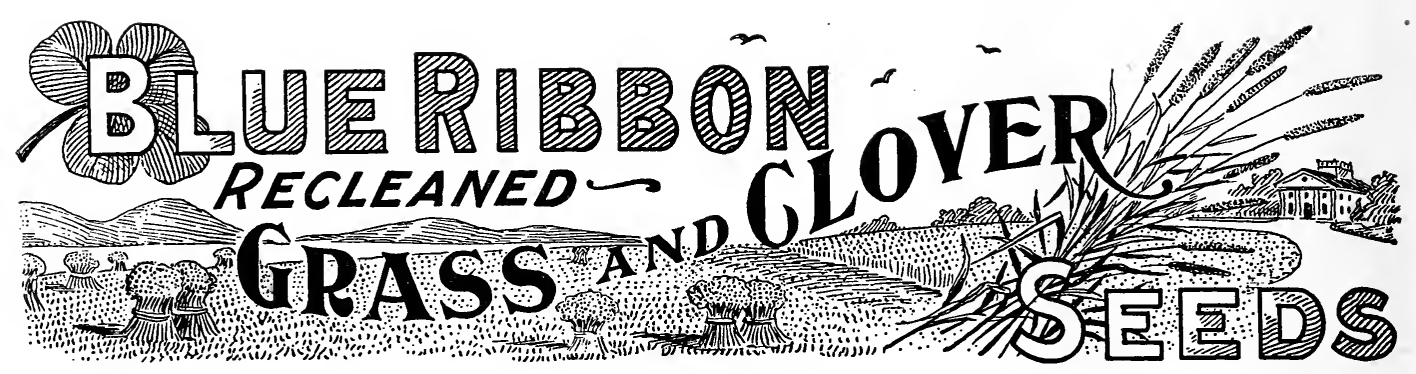

QUALITY is the most important question in Grass and Clover Seeds. While we carry the out under our trade-mark, BLUE RIBBON SEEDS.

\section{Successful Grass Growing}

PREPARATION. Too much stress can not be laid on thorough preparation of soil if the largest and most successful crops are to be produced. Foul land would be better if put in some grain crop or millet at first for smothering out weeds. Thorough plowing and repeated harrowing will pay handsomely, and no matter if it does take a little more expense, the results will justify in many times increased returns.

FERTILIZERS. Commercial fertilizers properly applied will give the best results for grasses, as they are free of weeds and will yield handsome returns. They are much cheaper, also, than barnyard manures. The best of all commercial fertilizers for grass and grain crops is Acme Brand Complete Grass Grower (see Fertilizers). Three hundred to five hundred pounds of this can be applied when seed is sown, harrowing in with the seed, and if a top dressing each spring of two hundred pounds of this mixture is applied it will keep up fertility and yield four or five tons of hay per acre continuously. This fertilizer is also the very best for wheat, oats, or corn, and even when only applied at one hundred pounds per acre, it will be seen that there is more available plant food in this quantity than is in four hundred pounds of the ordinary cheap mixed fertilizers so commonly offered.

sowING. Sowing can be done either in spring or fall. If in the spring, February and March are best for the Middle States, and April for Northern latitudes, and sowing can be done in nearly all the summer months in extreme Northern States. Fall sowing in middle latitude is best in August and September, many farmers sowing in October, when fall grain is sown. In the Southern States grasses are sown in most of the winter months, and clovers after danger of freezing. The seed can be sown with a drill running shallow, or with a rotary seeder, wheelbarrow seeder, or by hand. Mark off the land in a width as can be conveniently sown, dividing the seed for such portion, sowing one half in going one way over the portion of the land, then returning the same way sowing the other half, so that it is spread uniformly all over the field. Cover grass seeds about one half inch deep; clover and heavy seeds one inch. Always roll after covering.

\section{W. S. \& Co.'s Blue Ribbon Grass and Clover Seed Mixtures}

\section{For Hay and Permanent Pastures for Various Soils.}

Prices based on market quotations at the time this catalogue was published (January 1st). When large quantities are desired we will quote special prices.

In making these mixtures we have selected varieties that are suitable for sowing together, and they are combined in proper proportions to afford the very best results, both for hay and pastur-
age. The yield of hay is very largely increased when the proper combination of grasses is used, the aftermath is much better affording very much better pasturage. In all of our Grass Seed Mixtures we use the very best seeds only, the quality and purity of the seeds being our first consideration.

MIXTURE No. 1. For Light Sandy or Loamy Soils.

Creeping Bent Grass, Tall Oat Grass,

Orchard Grass,

Fancy Red Top,

White Clover,

Sheep Fescue,

Red Clover.

Sow 20 pounds per acre.

Price, per lb. 20c, 20 lbs. $\$ 3.40,100$ lbs. $\$ 16.00$.

MIXTURE No. 2. For Limestone, Stiff or Loamy Upland Soils.

Orchard Grass,

Ky. Blue Grass,

Tall Oat Grass,

Perennial Rye Grass, Red Clover.

Sow 25 pounds per acre.

Price, per lb. 20c, 25 lbs. $\$ 3.50,100$ lbs. $\$ 13.50$.

MIXTURE No. 5. Especially for the South on any

Bermuda Grass, Fancy Red Top,
MIXTURE No. 3. For Heavy Loam or Clay, or Bottom Lands.

Timothy, Meadow Fescue,

Red Top, Fancy, Alsike Clover,

Mammoth Clover.

Sow 18 pounds per acre.

Price, per lb. 20c, 18 lbs. $\$ 2.00,100$ lbs. $\$ 10.00$.

MIXTURE No. 4. For Wet Bottom

Land, Subject to Overflow.

English Blue,

Red Top, Fancy,

Italian Rye Grass,

Rough Stalked Meadow, Mammoth Clover.

Sow 25 pounds to the acre.
Price, per 1b. 20 c, 25 lbs. $\$ 3.25,100$ lbs. $\$ 12.25$.

good Soil, withstanding hot, dry weather.

English Blue,

Tall Oat Grass. 


\section{GENERAL LIST OF GRASS SEEDS}

\section{Owing to Excessive Drought}

most pastures and meadows have been severely injured, and we expect an enormous trade in Grass and Clover Seeds, with advancing markets. Don't put off buying until you are ready to sow. You will no doubt save money, and possibly disappointment, by purchasing early.

Market Changes Grass and Clover Seeds are constantly changing, and the prices given here are those ruling at the time this catalogue was published (January 1st). All orders will be filled at lowest prices when they are received, or we will take pleasure in quoting special prices at any time.

ORCHARD GRASS (Dactylls Glomerata). Called Cocksfoot in Europe and Dog's Foot in some sections. This grass grows luxuriantly on upland, loamy, or moderately stiff soils, and it will do well on all soils not water-sogged. We have seen fine crops on low flat lands and equally luxuriant growth on hill tops. It starts very early in the spring, produces luxuriant growth, can be pastured until April, the cattle then being removed and hay crop cut, then immediately pastured again, or left for a second crop of hay. Grows 3 to 5 feet in height, ready to cut three weeks ahead of Timothy, and is not nearly so exhaustive to the soil. If cut in bloom it yields a large crop of very fine nutritious palatable hay, though if allowed to get a little old the stalks become hard and woody and much of its value is lost. Crops of five or six tons of fine hay besides 11,000 to 12,000 pounds of green forage have been frequently made.

Seed should be sown thickly for best results. Close cutting and hard pasturing seems beneficial, as it has a tendency to grow in clumps or stools. For this reason a mixture with other grasses, such as Tall Meadow Oat, Red Top, Meadow Fescue, are desirable especially for pasture. When sown alone 2 to 3 bushels is best for hay, $11 / 2$ to 2 bushels for pasture, and $3 / 4$ to 1 bushel for seed; 5 or 6 pounds of Red Clover is usually sown with it for as the first year the clover increases

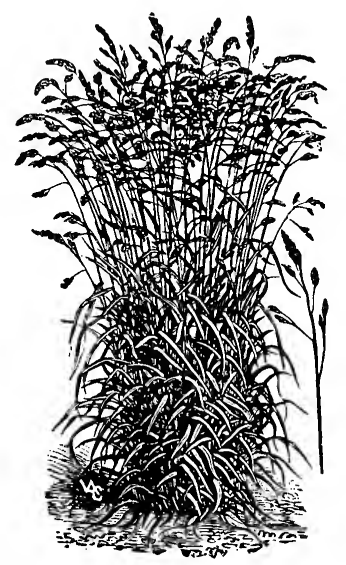

Orchard Grass the crop of hay, afterwards as this dies out the Orchard supersedes it. Present price, Blue Ribbon Brand, per lb. 20c, $\$ 2.40$ per bu. (14 lbs.); 5 bushels and over $\$ 2.35$ per bushel. Current prices on request.

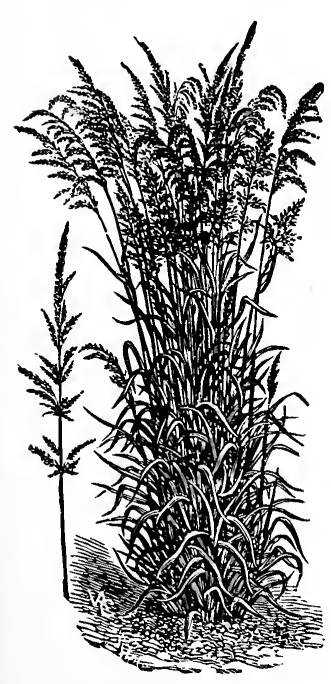

Tall Oat Grass

TALL OAT GRASS (Avena Elatior). Also called Evergreen in some sections. This important grass is suitable to nearly all upland soils, growing well even where sandy, makes thick, luxuriant growth, splendid for grazing, and if cut at the proper time yields large crop of good nutritious hay. It grows 3 to 5 feet in height, ripens about the same time as Orchard Grass, has a large amount of leaf growth, and is fine for sowing in connection with it for hay or pasture. Tall Oat Grass does not have the tendency to grow in clumps as does Orchard Grass, it makes an even stand of grass and if used in combination with it fills in the spaces or bare spots which are sometimes produced in an Orchard Grass field not receiving proper attention. Tall Oat Grass has great power to withstand the heat and drought of midsummer as well as the cold winter. Can be pastured very early in the spring, continues to give good grazing until late in fall, and for hay can be cut twice in the season, yielding considerably larger crops than Timothy. Its nutritive qualities are first class. Should be cut when in full bloom as if it gets too old it becomes unpalatable to some extent. It should enter into a combination of hay or pasture in all mixtures for this purpose. If sown alone use 2 to 3 bushels per acre. A suitable mixture will be found in No. 1 and No. 2 Mixtures. Weight 11 lbs. per bushel. Present price, Blue Ribbon Best Grade, per lb. 20c, $\$ 1.75$ per bu. (11 lbs.). Special market prices on request.

KENTUCKY BLUE GRASS (Poa Pratensis). Also called June Grass, Green Meadow Grass, etc. This famous grass is well known in all sections and where the land is suitable is one of the most profitable of all for pasture. It generally grows well on any stiff or loamy soils in Central and Northern States where rich, moist though moderately well drained, and succeeds fairly well in some sections of the South where lime is present in the soil, being largely used with Bermuda Grass. Kentucky Blue Grass is at its best in the spring and fall months, but being rather sensitive to heat does not grow luxuriantly during summer. It takes a considerable time to get a good stand of this as it grows very slowly at the start, but when once established forms a close, compact turf, making a fine pasture and is most excellent for lawns. It is better to use a combination of grasses than Kentucky Blue alone, as other grasses which grow more luxuriantly at first will form the sod, but when Kentucky Blue is well established it will gradually spread over 


\section{GRASS SEEDS-Continued}

the entire plot, providing the land is at all suitable for it. It is, however, often sown alone at the rate of 2 to 3 bushels for pasture and 4 to 5 bushels for lawn purposes.

Our stock of Kentucky Blue Grass has been selected from seed which has not been heated, is of good germination and thoroughly cleaned. In purchasing Blue Grass be sure you are getting straight Kentucky seed if you want best results. Price, Blue Ribbon Brand, 20c per lb., $\$ 1.50$ per bu. (14 lbs.); 10 bushels and over $\$ 1.40$ per bushel. Current prices on request.

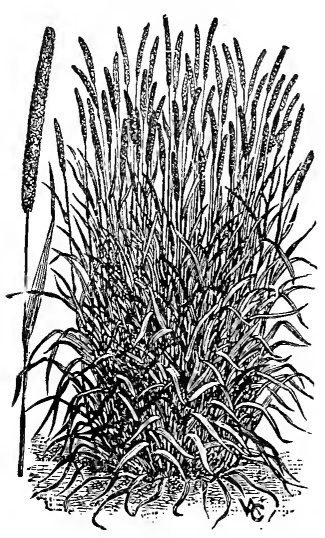

Timothy

TIMOTHY (Phleum Pratense). Called Herds Grass in sections of New York and New England. This standard grass is so well known that extended description is hardly necessary. There is nothing superior for hay, in fact Timothy hay is standard, but it does not bear grazing well on account of the tramping of cattle, and in biting it off many of the bulbs from which it springs are pulled up by the roots, hence Timothy meadows when pastured are soon destroyed. Timothy in this section and the South is best suited to rich bottom lands and tenacious rich soils not too wet and not subject to standing water. Ordinarily should yield $1 \frac{1}{2}$ to 2 tons of most nutritive hay which should be cut in full bloom; by heavy fertilization and care Timothy can be made to yield 8 to 10 tons per acre. When intending to pasture Timothy it is always better to sow other grasses in connection with it, and we recommend Alsike Clover, Red Top, Meadow Fescue, and a few other grasses, as outlined in our No. 3 Mixture. Red Clover is not suited to Timothy, as it is ready to cut three weeks earlier. If sown alone $1 / 4$ to $1 / 3$ bushels of Timothy is required. If sown with Red Top about one-fifth bushel of Timothy to four pounds of Fancy Cleaned Red Top. Our Blue Ribbon Brand of Timothy is specially selected of heavy, well-matured seed of good germination, and will produce the finest results. Present price, Blue Ribbon Brand, 10c per lb., $\$ 2.10$ per bu. (45 lbs.); 5 bushels and over $\$ 2.05$ per bushel. Seamless bags 20c each extra. Current prices on request.

RED TOP OR HERDS GRASS (Agrostis Vulgaris). Probably the most useful and one of the most desirable grasses in cultivation, succeeding better on more soils than any other grass in all sections of the United States. The first year Red Top grows somewhat slowly. It improves with age however, becomes very vigorous and spreads rapidly by means of its creeping root stocks. It is most suitable to stiff soils, but is fairly successful on hill sides and sandy soils. In low situations even where subject to overflow produces luxuriant growth and attains a height from 3 to $31 / 2$ feet and produces most excellent hay for which purpose cut when in bloom. Furnishes excellent pasture throughout the spring, summer, and fall months and ripens about the same time as Timothy. Formerly nearly all Red Top was used in the chaff. It is better, however, to use Fancy Clean Seed which is just as economical and much more satisfactory, as all impurities and inert matter are removed.

Our Blue Ribbon Brand Recleaned Seed will give the very best results, and 6 to 8 pounds of this per acre will produce more results than two or three bushels of the ordinary chaff. Present price, Blue Ribbon Brand, 20c per 1b., 100 lbs. $\$ 16.00$. Bags 20c each extra. Current price on request.

ENGLISH BLUE, MEADOW FESCUE OR RANDALL GRASS (Festuca Pratensis). Also called Evergreen Grass in some sections. We can not speak too highly of this valuable grass, and it has not received the general attention which it justly merits. It is exceedingly valuable for both hay and pasture, growing $2 \frac{1}{2}$ to 3 feet in height, succeeding well on nearly all classes of soil, but particularly suitable to moist and wet lands and does not seem to be injured by overflow. On upland soils it grows luxuriantly if the land is rich and as the roots penetrate deeply it is able to stand considerable drought and adverse conditions. Produces good yields of nutritious hay, lasts for a long period of years, and furnishes excellent pasture nearly all season. Its name Evergreen has been given it from the fact that it remains green even when the snow is on the ground and cattle will paw it off and find green nutritious grass under it. If sown alone $11 / 2$ to 2 bushels per acre are required, and if used in mixture a combination similar to our No. 2 or No. 3 Mixture is best. Present price, Blue Bibbon Brand, 15c per 1b., $\$ 2.25$ per bu. (24 lbs.). Bags included. Current market prices on application.

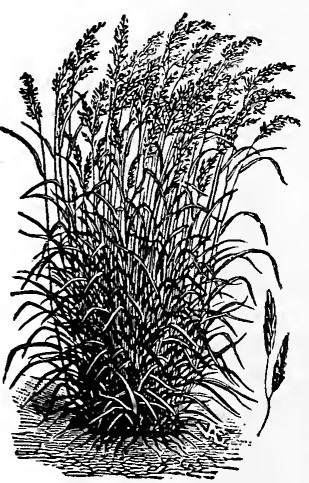

Meadow Fescue

ITALIAN RYE GRASS (Lolium Italicum). Particularly adaptable where cuick growth of hay is wanted, and more suitable to moist land. It has been used to good advantage in the Southern States, even as far south as Louisiana where in low river bottoms it affords good hay and pasture very early in the season. It starts extremely early, is of vigorous growth, and can be cut or grazed quicker than other grasses. Italian Rye Grass is a very vigorous grower and a gross feeder, hence for large crops should be on very rich soil or fertilized heavily. It is, however, short lived and not recommended alone for permanent meadows or pastures, but is excellent in mixtures with other sorts. If sown alone or with Red Clover use 2 to 3 bushels per acre. In mixtures from $1 / 2$ to 1 bushel. Per lb. 15c, bu. (14 lbs.) $\$ 1.10 ; 5$ bushels and over $\$ 1.00$ per bushel. Bags included. 


\section{GRASS SEEDS-Continued}

PERENNIAL RYE GRASS (Lolium Perenne). This is one of the standard grasses for hay and pasture in England and some sections of Europe, and has been used to very good advantage in various sections of the United States both for hay and pasture. It starts very early in the spring, is of vigorous growth, very succulent and nutritious, and especially valuable in mixtures both for hay and permanent pasture. If sown alone 2 to 3 bushels per acre; in mixtures from 8 to 10 pounds. Per 1b. 10c, bu. (14 lbs.) $\$ 1.10 ; 5$ bushels and over $\$ 1.00$ per bushel. Bags included.

HUNGARIAN, AWNLESS BROME GRASS OR SMOOTH BROME GRASS (Bromus Inermis). Introduced from Hungary, Europe, by the U. S. Dept. of Agriculture, and has been extensively sown in many sections. Particularly adapted to rather poor, dry soils which are not suitable to other grasses, and is useful for both grazing and hay, especially in mixture with other grasses. Sow from 2 to 3 bushels to the acre either in spring or fall. Per 1b. 15c, bu. (14 1bs.) $\$ 1.50$.

BERMUDA GRASS (Cynodon Dactylon). Becoming very popular and a great boon in the South for pasture, and when once established no amount of drought or hot weather will kill it out. On rich, loamy soil it will produce good hay, which is superior to Timothy in nutritive qualities: Bermuda Grass succeeds on nearly all soils, affording an abundance of leaves, furnishing constant growth of grass during the summer months, but becomes brown and bare in fall and winter. The dry leaf stalks, however, are very nutritive and readily eaten by stock, both green and dry. It can not be recommended too highly for pasture and general culture in the South, and is also excellent for summer lawns. In most sections on lands that are intended to be cultivated Bermuda Grass is regarded as a pest, as when once established it is extremely hard to eradicate. On waste lands of the South, on hill sides and banks, in fact in soils intended for permanent pasture nothing is more suitable. Its strong creeping roots will absolutely prevent wash, when once established it will stand more tramping Hungarian BromeGrass than any other sort of grass, hence makes the finest firm pastures. It is largely used for golf courses on this account, but some other grasses will have to be sown each fall on the sod for winter greens. Bermuda Grass likes rich soil, and to get a good stand on poor soil it is better to give a good application of fertilizer or manure when first sown. Blue Ribbon Best Grade, new crop, per 1b. 50c, postpaid $60 \mathrm{c} ; 10$ pounds and over at $45 \mathrm{c}$ per pound.

JOHNSON GRASS (Sorghum Halapense). A most prolific perennial hay and pasturage grass, eminently suitable to hot dry climates and soils. Much has been written for and against Johnson Grass, and while our own opinion is that in this section it should not be used, it is of immense value to the farmer in the extreme Southwestern States. It makes excellent hay and furnishes an enormous amount of grazing. No droughts, methods of culture, or application of chemicals to eradicate it will destroy it when once sown, therefore we do not recommend it to be sown on any land which is intended in future years for other crops. A small piece of root will soon so propagate itself so as to form a mat of Johnson Grass, and it propagates so easily that it will take possession of the soil and choke out other crops.

In the extreme Southern States where other grasses are not grown Johnson Grass flourishes luxuriantly and yields two or three tons of excellent hay per acre on good soil, besides enormous amount of pasturage.

The best time for cutting is before the heads appear, as if allowed to ripen it becomes unfit for stock. Many farmers speak in most favorable terms of the quality of hay from this grass, and it is now being used very largely as one of the standard hay crops for the South. Large stock farmers are using Johnson and Bermuda Grass almost exclusively for pasture in the South. The best time to sow Johnson Grass is in the spring, March or April, and it should be sown at the rate of 1 to $1 \frac{1}{2}$ bushels per acre. Price, Blue Ribbon Recleaned Quality, per lb. $10 \mathrm{c}$, bu. (25 lbs.) $\$ 1.50 ; 5$ bushels and over $\$ 1.45$ per bushel. Bags included.

CREEPING BENT GRASS (Agrostis Stolonifera). Also called Florin and Bent Grass. This grass is highly esteemed in many sections for pasture, and is especially valuable where fine close thick turf is desired. The creeping stoloniferous roots render it exceedingly well adapted to tramping, hence it is highly esteemed for pastures, lawns, and putting greens of golf courses as well as for polo grounds, bowling greens, etc. If sown alone 2 to 4 bushels are required. Price, Blue Ribbon Brand, per 1b. 30c, bu. (14 lbs.) \$3.75. Bags included.

SHEEP FESCUE (Festuca Ovina). Most valuable as a pasture grass for high and dry situations, affording good grazing where other varieties burn out. We especially recommend this grass in mixtures where long droughts are liable to injure other sorts. The foliage is very fine in texture, it has a tendency to grow in tufts, hence close grazing is desirable. If sown alone use $1 \mathrm{I} / 2$ to 2 bushels per acre, or in mixtures 10 to 12 pounds per acre. Per $1 \mathrm{~b}$. $15 \mathrm{c}$, bu. (14 $1 \mathrm{bs}$.) $\$ 1.75 ; 5$ bushels and over $\$ 1.70$ per bushel. Bags included.

WOOD MEADOW GRASS (Poa Nemoralis). This belongs to the same family as Kentucky Blue Grass, and is more suitable to low loamy situations and for shady lawns and pastures. Blue Ribbon Brand, per $1 \mathrm{~b}$. 60c, bu. (14 1bs.) $\$ 6.00$. Bags included.

ROUGH STALK MEADOW GRASS (Poa Trivialis). This is eminently suitable to the same use as Wood Meadow; is of considerable nutritive qualities and is exceedingly relished by horses, cattle, and sheep. In moist soils in connection with other grasses it yields good crop of hay, while for pasture is excellent. Sown alone requires from 1 to $1 \mathrm{1} / 2$ bushels per acre; in mixtures 4 to 5 pounds. Blue Ribbon Brand, per lb. $40 \mathrm{c}$. bu. (14 lbs.) $\$ 4.00$. Bags included. 
Prices subject to market changes. Orders entrusted to us will be supplied at market rates on day received. Blue Ribbon Best Grades are recleaned and of highest quality. In ordering Clover Seeds always remit for Seamless Bags holding $2 \mathrm{I} / 2$ bushels, $20 \mathrm{c}$ each extra.

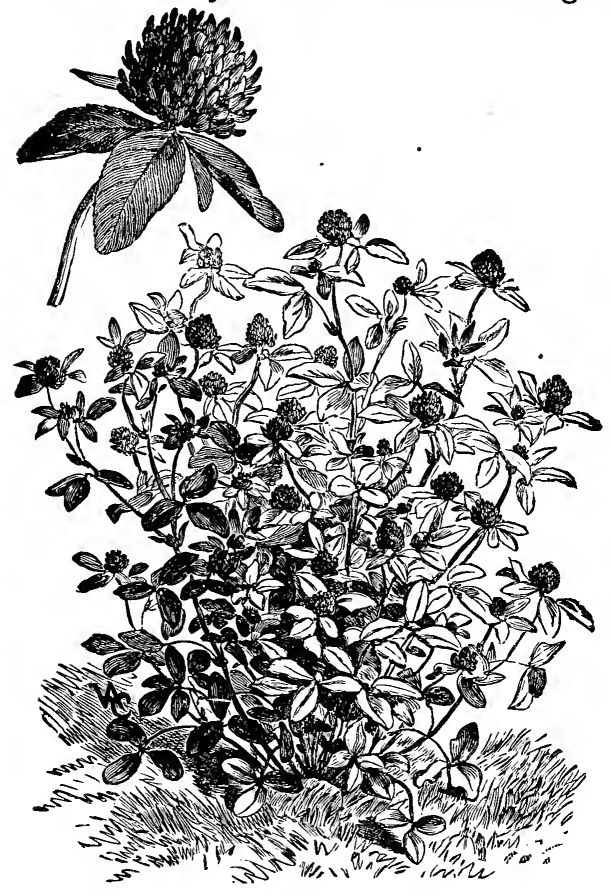

Red Clover

RED CLOVER (Trifolium Pratense). Well known and probably the most valuable of all crops for temperate latitudes for grazing, green forage, and hay. As a soil improver clover is very highly esteemed. Its roots penetrate to great depths, bringing up plant food from the lower soil as well as absorbing and fixing nitrogen from the atmosphere.

Clover can be sown in the spring from February to April in this locality, varying earlier or later according to other latitudes. Excellent results can also be obtained from sowing it on late snows, as with the melting of these the seed soaks into the earth about the right distance. Light grass seeds, however, sown on snows are apt to float away and not have sufficient coverage, hence not recommended. The summer and early fall sowing of clover is also giving most satisfactory results, and a full crop can be cut the succeeding year when this is done. Seed is usually sown from $1 / 8$ to $1 / 4$ bushel per acre alone, or in connection with other grasses 5 to 6 pounds. Price, Blue Ribbon Brand, per 1b. 15c, bu. of 60 lbs. $\$ 6.25 ; 5$ bushels and over $\$ 6.10$ per bushel. Bags holding $21 / 2$ bushels each $20 \mathrm{c}$ extra. Price fluctuates; current quotation on request.

SAPLING OR MAMMOTH CLOVER. Also called Pea Vine or English Clover. Similar to above except of ranker growth and blossoms three weeks later, more valuable for soiling, and by many farmers preferred for medium or poor soils, but on rich land produces too rank a growth and usually contains too much seed for horses, though is good for cattle. The aftermath from Sapling Clover is fine for pasture. Use the same quantity and sow at the same time as Red Clover. Price, Blue Ribbon Brand, per 1b. 15c; bu. of $601 \mathrm{bs}$. $\$ 6.35$; 5 bushels and over $\$ 6.25$ per bushel. Bags holding $2 \frac{1}{2}$ bushels each 20c extra. Current prices on request.

ALSIKE CLOVER (Trifolium Hybridum). Also called Swedish Clover. This is being used very largely now in all sections mainly on account of the general trouble of getting a good stand of Red Clover. In growth it is similar to Red Clover, though not quite so large a plant nor quite as vigorous. It has a lighter colored blossom, ripens two or three weeks later, hence splendid in connection with Timothy or Red Top. Alsike Clover produces good hay, is fine for pasturing, grows better on low land than Red Clover, succeeds admirably on upland soils, and as it is a perennial lasts much longer time. If alone use 5 to 8 pounds, or in mixtures of grasses 3 to 4 pounds. Price, Blue Ribbon Brand, per 1b. 20c, bu. of 60 lbs. $\$ 9.50 ; 5$ bushels and over $\$ 9.35$ per bushel. Bags holding $2 \mathrm{~T} / 2$ bushels each $20 \mathrm{c}$ extra. Current prices on request.

JAPAN CLOVER (Lespedeza Striata). This has been widely extended over the Southern States and is found growing in many sections along ditch banks, road sides, and in waste fields. It is particularly suitable for waste lands, woodland pastures, grows fairly well on poor soils and spreads rapidly, and when once established usurps wild growths, and will in many cases even subdue Broom Sedge. It is not, however, a pest, and can be gotten rid of by plowing it up, and is excellent as a fertilizer.

Japan Clover is particularly valuable for pas-

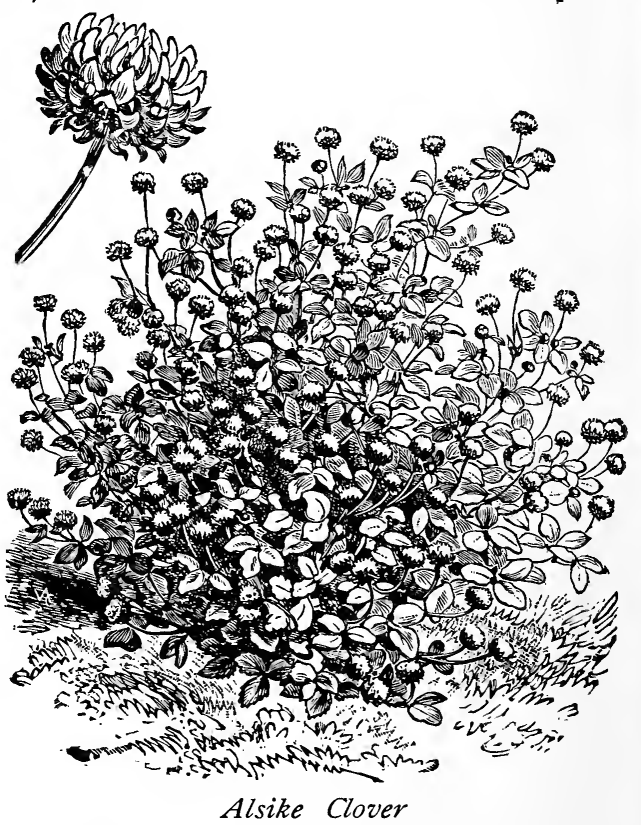
ture on such soils as described, and where the soil is good yields a fair quantity of good hay. It is relished by cattle, is nutritious and fattening. To obtain a stand it is only necessary to scatter the seed broadcast in the spring during March and April at the rate of about 10 pounds per acre. Harrowing the land over before the seed is sown when it can be done is of course better, though this is not imperative to obtain a good stand. Price, per lb. 25c, bu. of 25 lbs. $\$ 5.00$. Bags 20 c each extra. 


\section{Alfalfa or Lucern}

(Medicago Sativa)

There is no trick about getting a good stand of Alfalfa, and no doubt about securing good results under reasonably good conditions. The question of physical condition of the soil is of main importance. Loose or loamy soils, or soils with gravelly or sandy subsoils, are splendidly adapted to it, for the roots go down to great distances, therefore its immense value in hot, dry climates. Clay or very heavy soils are not suitable, but on loamy, sandy, or limestone soils it is very successful, in this latitude and all sections of the South. In this section three or four crops per year are cut, and it succeeds admirably in loamy, sandy, or deep limestone soils.

Preparation and Sowing.-Clean land, preferably that which has been planted in cultivated crops, should be broken up as deeply as possible, subsoiling where not liable to wash. Then harrow thoroughly, getting the top soil just as fine as possible. Then roll with a heavy roller to make a firm seed bed. Then sow good seed twenty pounds per acre broadcast. Then cover with a spike-tooth harrow running shallow. Then roll again to press the soil firmly around the seed. A slight top dressing of wellrotted stable manure is most excellent, or an application of two hundred pounds good commercial fertilizer broadcast will be beneficial. The best time for seeding in this latitude is from the 15 th of March to the 15 th time for seeding in this latitude is from the 15th of March to the 15th later. In the fall, seeding had better be done in August if possible in this section, and further South, later if desired.

Uses and Care.-Alfalfa yields four to eight cuttings per season, depending on section. It should not be grazed. When to be used for green feed cut in the morning and let it wilt a little, as too much green food

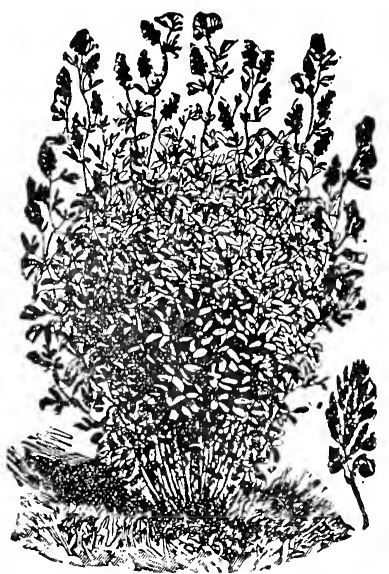

Alfalfa

is apt to injure stock. For hay, cut closely when in bloom, let it lay twenty-four hours, then rake in windrows and when dry stack in the field with straw covering or stored under cover like clover, handling as little as possible to keep from shedding the leaves. An occasional top dressing of manure and with ordinary care, an Alfalfa field will last for twenty years, and the best crops are usually produced when three or four years old.

Inoculation.-On most soils in this section we do not consider inoculation necessary, especially where there is an indigenous growth of Sweet Clover. Bur Clover sown the previous year is used quite extensively in the South to inoculate land for succeeding crops of Alfalfa. In sections where Sweet Clover or Bur Clover are not grown, inoculation will in most cases be of benefit, and we can supply inoculating Bur Clover are not grown, inoculation will in most cases be of benefit, and we can supply
material for applying to the seed before sowing. Circulars for further information on request.

PRICES. Poor or old Alfalfa is not worth sowing. Always buy the best. Many farmers prefer Native seed to Imported. We can supply both stocks in first-class grades, though Imported seed is brighter, nicer looking seed.

BLUE RIBBON BEST GRADE, per lb. 20c, 10 lbs. $\$ 1.60$, bu. $\$ 9.00,5$ bu. $\$ 8.85$ per bu. Bags 20c each extra. Ask for special prices.

INOCULATION BACTERIA FOR ALFALFA. Trial bottle 50c, for one acre $\$ 1.50$, for five acres $\$ 5.00$.

\section{CLOVER SEED-Continued.}

WHITE CLOVER (Trifolium Repens). Well known, indigenous in nearly all temperate latitudes. It forms a thick, close turf, is excellent to sow for pastures, especially on sandy soils, and should enter into the composition of all lawn mixtures. Alone it requires 4 to 6 pounds per acre; in mixture from 1 to 2 pounds. Blue Ribbon Best Grade 25c per lb.; 5 pounds and over 20c per pound; bushel prices quoted on request.

CRIMSON CLOVER. Recommended for fall seeding only and should be more largely used in Kentucky, Tennessee, and Southern States. Produces an excellent hay and fine winter pasture. This is one of the finest of all soil improving crops. Per 1b. 10c, bu. (60 lbs.) $\$ 3.75 ; 5$ bushels and over $\$ 3.65$ per bushel. Current prices quoted at any time.

BUR CLOVER (Medicago Maculata). For fall sowing only.

\section{Giant Beggar Weed or Florida Clover}

(Desmodium Molle)

A crop of immense value for restoring fertility to worn-out or depleted soils. On sandy lands of the Southern States it is probably the most valuable forage plant which can be sown, besides being of immense benefit to the soil. Its growth is immense, sometimes attaining a height of seven feet; is densely covered with leaves, yields both hay and pasturage abundantly, and is of high nutritive value, many farmers estimating its feeding value equal to clover. Sow any time after frost and as late as the middle of June, if in drills three feet apart three to four pounds per acre, or broadcast ten to twelve pounds per acre, covering one to two inches. If cut when two feet high, either for hay or green food, it will branch out from the roots, producing successive crops. Can be easily eradicated, and is in no sense a pest. Per $1 \mathrm{~b}$. $35 \mathrm{c}, 10 \mathrm{lbs}$. and over at $30 \mathrm{c}$ per $\mathrm{lb}$.

Find three dollars for Crimson Clover Seed, the Wood-Stubbs variety that is always sure to come and grow, for I have never gotten any seed from you yet that failed to come up.

J. H. SHEBY.

Henry County, Ky., Sept. 24, 1908. check for more.

Your seed have all been very good.

Clay County, Ky., Oct. 16, 1908 . 


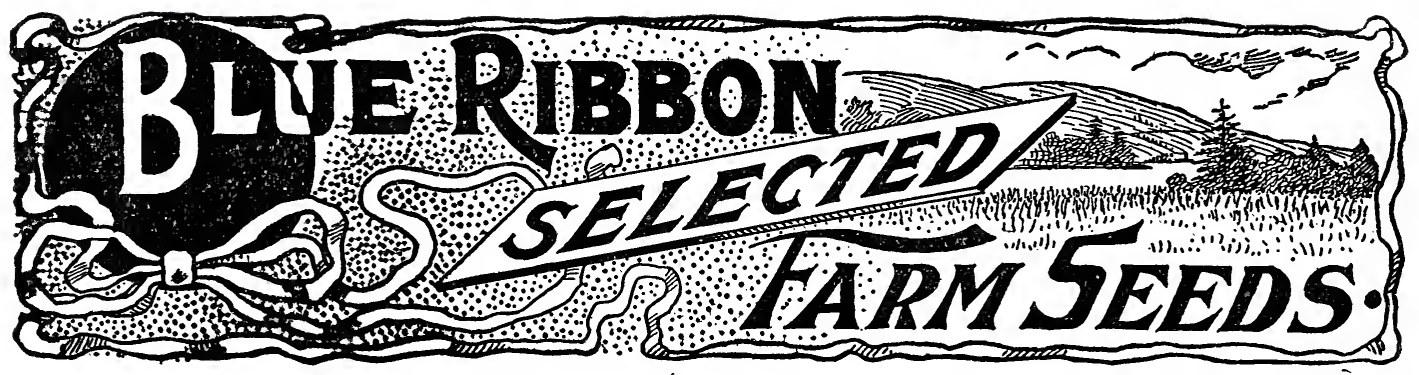

\section{Selected Seed Corn}

While we can not emphasize too much the value of selection, it must be borne in mind that for largest yields, acclimatization to a certain section is more important than mere selection. For instance, we have found from long experience that corn from northern sections of Illinois, Ohio, and Iowa, while in most cases maturing earlier, does not produce the yield in this latitude that good, select stock will grow here, nor do we believe there is any section in the United States more eminently suited to growing seed corn than this. We have been most careful in the selection of our seed corns, and customers can rely on all stock

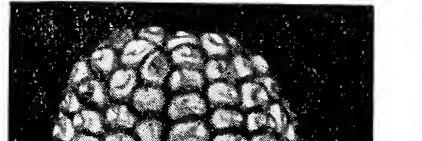
as being first class, thoroughly matured, dried, and of good germination.
Prices do not include bags. White, seamless sacks hold- ing $2 \mathrm{I} / 2$ bushels will be furnished for $20 \mathrm{c}$ each. New striped grain bags at $12 \mathrm{c}$ each. Bushel bags $10 \mathrm{c}$ each. Prices on pecks and half bushel bags each $8 \mathrm{c}$.

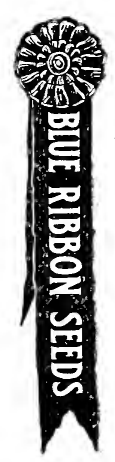

\section{Seed Corn on Ears As many of our customers prefer to}

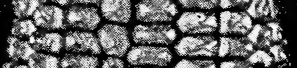

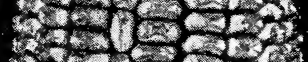

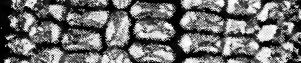

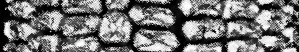

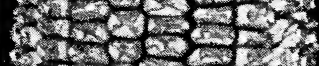

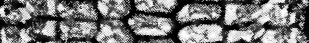

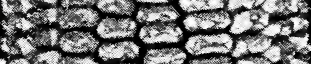

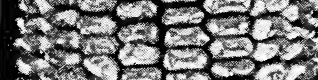

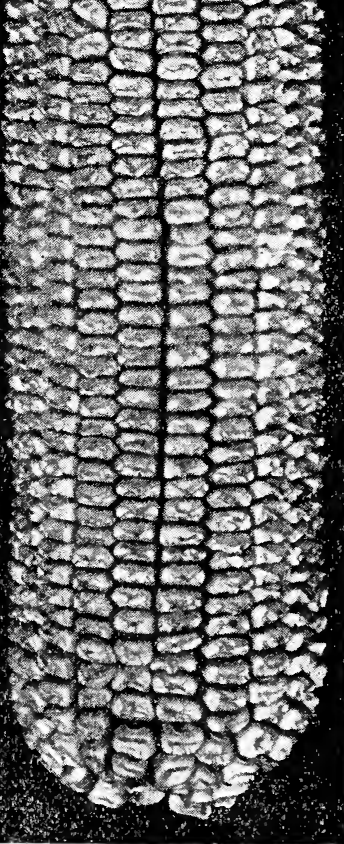
ing, we offer some of our stocks on ears as well as shelled. It is always more satisfactory to purchase seed corn on ears. You see exactly what you are getting, and by careful selection of grain a more uniform and better stand is obtained.

\section{Improved Boone County White Blue Ribbon Stock.}

Boone County White Corn has been recognized in all States as the finest variety of corn ever introduced for middle and southern latitudes. It is recommended by the most eminent authorities, and has always produced good yields of most excellent quality and a splendid keeper. Our stock of this is the most improved and carefully selected type. It is a highly bred white corn, extra large size, contains a high percentage of protein, maturing about medium. The ears are 8 to 11 inches long, $7 \frac{1}{2}$ to 8 inches in circumference, containing 18 to 24 rows, and averaging in weight from 12 to 18 ounces. The cob is medium to large pure white, the ears resembling a cylinder rounding off within an inch of the tip, and both butts and tips are remarkably well filled, grains are very deep, fine large germ, and the greatest yielding corn in existence.

Our Blue Ribbon stock of Improved Boone County White was awarded first prize over eight entries at the Indiana State Fair at Indianapolis in 1905. At Johnson County, Indiana, Corn Show in 1906 was awarded grand prize, thirty ears selling for $\$ 30.00$ cash at auction. At Indiana State Fair, 1906, it was awarded first prize, and a sample of ten ears scored 96 8-10 points. At the World's Fair in St. Louis it was awarded the silver medal. At the Kentucky State Fair, 1908, it was awarded first prize, the stock being grown by $\mathrm{Mr}$. Helm Marriott of Jessamine County. Hon. M. C. Rankin, Commissioner of Agriculture of Kentucky purchased quite a lot of this corn from us in 1908 and states to us that it has given perfect satisfaction in some instances, giving an increased yield of $40 \%$ in field trials.

We do not consider there is any better stock of this to be obtained anywhere, and can offer it unqualifiedly to give satisfaction.

Price-Qt. 15 c, postpaid 30 ; pk. 60 c, bu. $\$ 1.75 ; 5$ bushels and over $\$ 1.65$; sacks extra.

On Ears-Each postpaid 15c; one bushel crates $\$ 2.00 ; 5$ bushels and over $\$ 1.90$ per bushel; crates included.

Imp. Boone County White 


\section{SELECTED SEED CORN-Continued}

IOWA SILVER MINE. One of the best early white corns which matures in this locality in 85 days. It is pure white, grain is solid, dented, and produces finest meal. Ears are of good length, symmetrical, well filled; grains are deep, narrow, averaging 18 to 20 rows solidly packed on the cob. Stalks 7 to 8 feet high, usually producing two good ears, which are set low on the cob. This corn is very popular as a main field crop in the North and West, and is the principal sort grown by many of the largest farmers. In Kentucky and the South it is highly esteemed by stock raisers on account of being a quick good yielding variety producing a medium sized ear for feeding. We highly recommend it for where a quick maturing sort is desired.

Price-Qt. $15 \mathrm{c}$, postpaid 30c; pk. 50c, bu. $\$ 1.60 ; 5$ bushels and over at $\$ 1.50$ per bushel. Bags extra.

MAMMOTH RED COB WHITE DENT. One of the best all round white sorts for rich land, producing largest crops of finest quality corn. The ears average about 10 inches in length, of uniform size and great depth of grain, rows 18 to 34 on red cobs, well filled. The grains are pure white, solid, very deep, producing the finest milling white corn. The yield of this superior corn is very large, sometimes as much as 90 bushels per acre. We unhesitatingly recommend it, both for yield of grain or using for ensilage.

Price-Qt. $15 \mathrm{c}$, postpaid 30c; pk. 50c, bu. $\$ 1.60 ; 5$ bushels and over at $\$ 1.50$ per bushel. Bags extra.

HICKORY KING. An old favorite sort well known in this locality. Ears are rather small, but usually 2 or 3 on the stalk, and it is a good yielder. The cobs of this variety are small, a single grain of corn sometimes being large enough to cover cross sections of the cob. The grains are very large, flinty, and of the finest quality for milling or feeding. This corn is particularly good for the early crop, and will give satisfactory results. Qt. $15 \mathrm{c}$, postpaid $30 \mathrm{c} ; \mathrm{pk}$. $50 \mathrm{c}$, bu. $\$ 1.60 ; 5$ bushels and over $\$ 1.50$; sacks extra.

EARLY NORTHERN WHITE FIELD. This is a particularly valuable variety for very early planting or for very late. In fact, when too late for other sorts to mature, this will still make good yield of very fine, well-filled ears. The ears are of moderate size, grain medium length, usually produces two good ears to the stalk, and a remarkably good producing sort considering its earliness in maturing. By far the most popular sort in this neighborhood for late roasting ears, and by many gardeners used as their dependence for a crop. $Q t$. $15 \mathrm{c}$, postpaid $30 \mathrm{c}$; pk. 65 c, bu. $\$ 2.00$; sacks extra. Special prices in large lots. On Ears, 30c per dozen, $\$ 2.00$ per 100.

\section{Yellow Varieties of Seed Corn}

GOLD STANDARD LEAMING. An ideal feeders' corn, of light golden color, ears slightly tapering and cylindrical. The ears range from 8 to 11 inches long, 7 to 8 inches in circumference, and is well filled, butts and tips. The ears have from 16 to 24 rows, little or no space between them, cob is red, medium size; and the percentage of corn as compared to the cob varies from 86 to 90 per cent. The per cent of protein which these grains contain is more than any other corn which we know, and four bushels of Gold Standard Leaming will put as much fat on a hog or steer as five bushels of ordinary corn. The fact that the ears are moderate size, matures early, and splendid yielding, has made this one of the most popular of all the yellow sorts. Price: Qt. 15c, postpaid 30c; pk. 50c, bu. $\$ 1.75 ; 5$ bushels and over $\$ 1.65$. On ears, each $15 \mathrm{c}$, postpaid; bu. $\$ 2.00 ; 5$ bushels and over $\$ 1.85$; crates included.

GATE POST (New). This is one of the finest varieties of Yellow Corn we have ever seen for general purposes. While the ears do not grow as large as Golden King, the depth of grain is marvelous and we believe in a shelling contest it would yield more corn than any yellow in existence. The stalks are medium height, bearing one and two nice, smooth ears 9 to 10 inches in length. Color rich golden yellow, shading lighter at the tip; grains very solid, exceedingly long; ears 16 to 18 rows, well filled and very heavy. Most desirable for feeding on ears, splendid yielding, early maturity, and altogether a first-class sort for general cultivation, especially on only moderate rich soil. Qt. $15 \mathrm{c}$, postpaid $30 \mathrm{c} ; \mathrm{pk}$. $50 \mathrm{c}$, bu. $\$ 1.60 ; 5$ bushels at $\$ 1.50$ per bushel.

YELLOW DENT. A medium early yellow variety producing well-filled ears, of good length and filling out remarkably well even under adverse conditions. Stalks of good height, producing one to two good ears which average 10 to 11 inches long, 14 to 16 rows. Grains flinty, deep, slightly dented, rich color, and fine feeding quality. Qt. $10 \mathrm{c}, \mathrm{pk} .40 \mathrm{c}$, bu. $\$ 1.40 ; 5$ bushels at $\$ 1.35$.

EARLY RED DRIVER. A well known and popular early red eared variety producing fair sized ears. Very valuable for early or very late planting and produces good crops for so early a sort. This is highly esteemed with some growers for use green as a table sort and universally liked for stock feeding. Qt. 15 c, pk. 50c, bu. $\$ 1.75 ; 5$ bushels at $\$ 1.70$ per bushel. Sacks extra.

The Seed Corn I bought from you in the spring has done well. Warren County, Tenn., Aug. 1, 1908. E. P. STUBBLEFIELD.

Vanderburg County, Ind., March 1, 1908 Three or four years ago I bought some Harvest King Wheat, and was well satisfed with it. It is the best in our nelghborhood. 


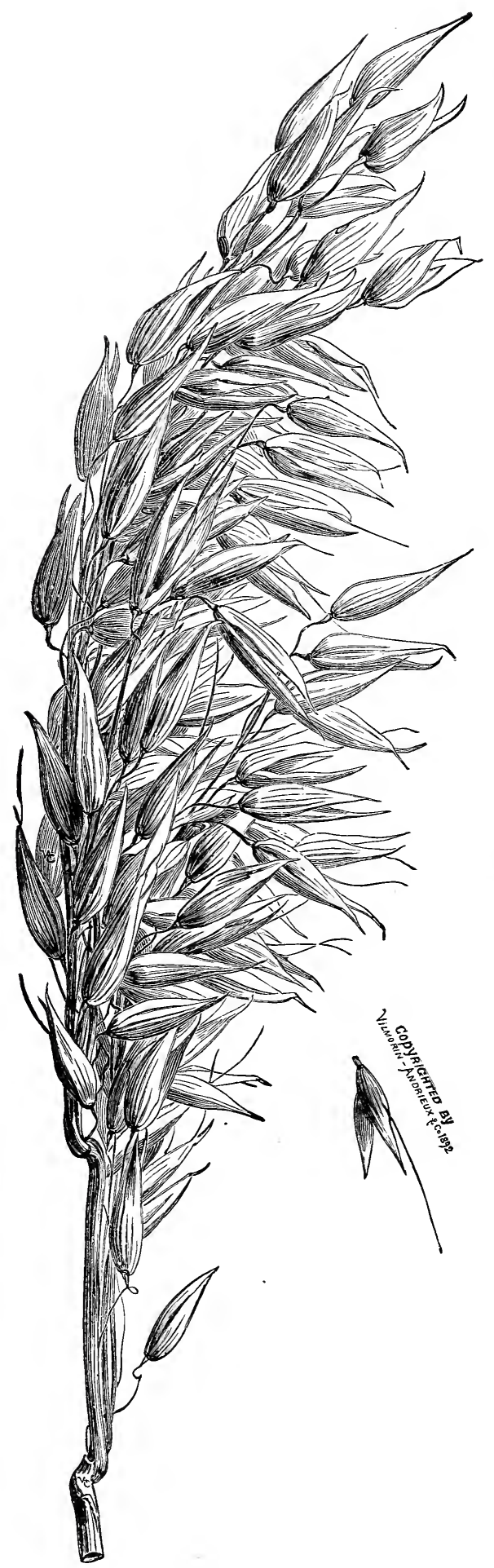

Winter Turt Oats
Seed Oats

Winter Turf Oats If sown early, these are the best yielding and produce finer quality grain than spring oats. In good land they grow four to five feet tall, producing a splendid yield of very finest grain oats, which is so full of kernel that a measured bushel will run 40 to 42 pounds. The straw is not as coarse and hard as some of the coarse-growing spring oats, hence is valuable for feeding, and if the oats are cut green, will make as good hay almost as Timothy. They stand up well, however, and very little complaint is made of them lodging or falling. If sown in the spring they do not ripen quite as early as fall-sown, or quite as early as spring oats, but the yield will compare favorably, and the quality of grain is far superior to the ordinary spring varieties. They require $11 / 2$ to 2 bushels per acre.

Note.-Spring-sown Winter Oats make the finest seed for fall sowing, as impurities, such as cheat, wheat, and onion, are eliminated.

PRICE-Blue Ribbon Brand Recleaned Stock, per bu. $85 \mathrm{c} ; 10$ bu. and over, $80 \mathrm{c}$ per bu., bags included. Ordinary Oats, without recleaning, per bu. 80c; 10 bu. and over, $75 \mathrm{c}$ per bu., sacks included.

Silver Mine A very superior white Spring Oat, which is immense yielding and produces fine, heavy white grain. They are of medium height, heavy straw, withstanding inclement conditions better than ordinary white Spring Oats, and much more profitable to sow. In this latitude Silver Mine Oats in comparative trials have proven so immensely superior in yield that we strongly advise their extended use in preference to other spring oats.

PRICE.-Pk. 25c; bu. $85 \mathrm{c} ; 10$ bu. and over, $80 \mathrm{c}$ per bu. Stock limited.

Black Spring Oats Usually preferred for thin land, growing taller and producing heavier yield of oats. They make more forage than White Spring Oats, therefore are better to cut when green. W. S. \& Co.'s Best, recleaned choice stock, per bu. $65 \mathrm{c} ; 10 \mathrm{bu}$. and over, $63 \mathrm{c}$ per bu., sacks included.

White Spring Oats Our best recleaned stock of these are Choice Northerngrown, all heavy oat, which have been recleaned by us. W. S. \& Co.'s Best, per bu. 70c; 10 bu. and over at $68 \mathrm{c}$ per bu., sacks included.

\section{Sorghum or Cane}

Bags roc each extra

EARLY AMBER SORGHUM. Furnishes a large yield of most nutritious forage, which can be fed either green or cured, and will yield two or three cuttings a year, stooling out thicker each time it is cut. The saccharine matter is of the first quality, and it also produces a fine sugar or syrup. It grows ten to twelve feet high. This is the favorite sort in Northern and many Western States. Sow at the rate of one peck per acre in drills $3 \mathrm{t} / 2$ to 4 feet apart. Pkt. $5 \mathrm{c} ; 1 \mathrm{~b}$. $10 \mathrm{c}$, postpaid 20c; pk. 40c; bu. about $\$ 1.25$.

RED TOP SORGHUM. This is one of the best varieties of Sorghum, whether for syrup or feeding green or cured for stock. It grows luxuriantly, is as tall as Early Amber, a heavy cropper, and the seed produced in a closed head, making it easily gathered. It is largely planted in this section, and is a favorite sort among Kentucky farmers. Pkt. 5c, 1b. 10c, postpaid $20 \mathrm{c}, \mathrm{pk}$. $40 \mathrm{c}$, bu. (50 lbs.) about $\$ 1.35$.

EARLY ORANGE SORGHUM. This variety is a favorite wherever grown. It is similar in growth to Early Amber, but is preferred in Tennessee and Southern States, as it produces a heavier crop. Lb. $10 \mathrm{c}, \mathrm{pk} .40 \mathrm{c}$, bu. $\$ 1.25$. 


\section{COW PEAS - The Great Soil Improvers}

Make Poor Land Rich. Make Good Land More Productive. Also makes a Splendid and Nutritious Green Forage or Hay Crop, Enriching the Soil even when the Crop is cut off.

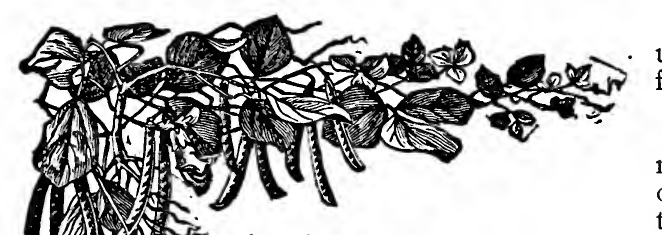

Prices are approximate only, as market is very unsettled at time this Catalogue is published. Write for quotations, stating quantity wanted.

Cow Peas are fast superseding all other crops in middle and southern latitudes for soiling, and are one of the leading crops for hay. It has been estimated that a good crop of Cow Peas plowed under will equal in nitrogen twenty tons of stable manure per acre. There is not a surer or more economical method of improving soil than plowing under leguminous crops, and nothing is superior for this purpose to Cow Peas. Sow in May, June, or July, at the rate of 1 to $1 / 2$ bushels per acre, broadcast or in a wheat drill.

NEW ERA. The peas are dull lead colored, not quite as large as the Whippoorwill, but the vine is somewhat longer. The fact that it produces as large a growth in quicker time than the Whippoorwill, and also its crop of peas two or three weeks sooner, has been the cause of it being very popular in sections through the North and West, where the season for the production of this crop is shorter. Price about \$1.75 per bu. Special price in large lots. Small quantities: Pkt. $10 \mathrm{c}$, postpaid; qt. $15 \mathrm{c}, \mathrm{pk}$. $60 \mathrm{c}$.

WHIPPOORWILL. A favorite early bunch-growing variety; has brown speckled seed, which are more easily gathered than from the vine-growing sorts. This variety is a prime favorite in the Middle West on account of its early maturity and habit of growth. Price fluctuates. Price about $\$ 1.75$ per bu. Special price on large lots. In small quantities: Pkt. 10c, postpaid; qt. 15c, pk. 60c.

BLACK COW PEAS. This variety, while a little later than Whippoorwill, produces more growth of forage and is consequently better for cutting and as a soil improver. It makes large yield of peas and is popular in the latitude of Kentucky. We consider Black Cow Peas the best sort for general soiling or hay purposes, which can be used in this latitude. Price about $\$ 1.75$ per bu. Special price on large lots. In small quantities: Pkt. 10c, postpaid; qt. $15 \mathrm{c}, \mathrm{pk}$. $60 \mathrm{c}$.

CLAY COW PEAS. A favorite variety in the Carolinas and Georgia; grow similar to Black, but produce a little more vine. The color is a little darker than the Wonderful or Unknown, being light brown. Price about $\$ 1.75$ per bu. Special price in large lots. In smaller quantities: Pkt. 10c, postpaid; qt. $15 \mathrm{c}, \mathrm{pk} .60 \mathrm{c}$.

MIXED COW PEAS. A mixture of Clays, Whippoorwills, Blacks, and some other sorts, which are offered at a low price. These can be profitably used for soiling or hay. Price, bu. about $\$ 1.70$. Price fluctuates. In small quantities: Pkt. 10c, postpaid; qt. 10c, pk. 60c.

BLACK-EYE PEAS. Large Black-Eye Peas make a profitable crop for picking the dry peas for sale in our markets during the winter; at the same time make an excellent soil improver, being similar in growth of vine and action of roots upon the soil to the other Cow Peas. While, of course, allowing the peas to fully mature, and harvesting the dried peas detracts somewhat from their value as an improver, still, where parties desire to make a money crop, and at the same time improve the soil, these are especially desirable.

Large Black Eye. Pkt. 10c, postpaid; qt. 25c, postpaid 40c, pk. $\$ 1.00$, bu. about $\$ 3.00$. Price fluctuates.

For Other Varieties of Cow Peas, ask for Prices.

\section{Canada Field Peas}

These Field Peas are entirely different to the Cow Pea, requiring to be sown early in the spring, making their crop ready for cutting in May or June. They are increasing in popularity every year, making a most satisfactory and large-yielding early forage crop. They can be sown in open weather during December, January, February, and March, and make large yields of most nutritious food, which can be used either green or cured for hay. It also makes a good green manuring crop to turn under, but is not equal in this respect to the Cow Peas. They can be sown alone at the rate of $1 \mathrm{x} / 2$ to 2 bushels to the acre, but a light seeding of oats, rye, or barley will increase the yield and help to support the pea vines when the crop comes to maturity. Price fluctuates. Price, January 1st, pk. 50c, bu. \$1.75. Special price quoted on large lots. Cotton bags holding 2 bushels each, $20 \mathrm{c}$ extra.

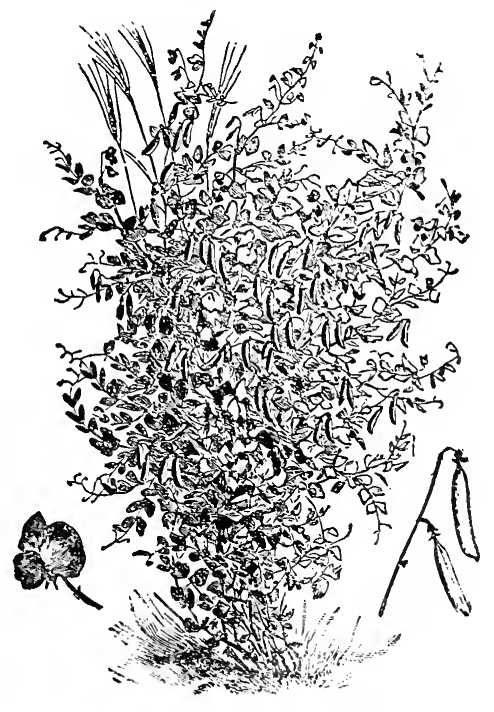

Canada Field Feas 


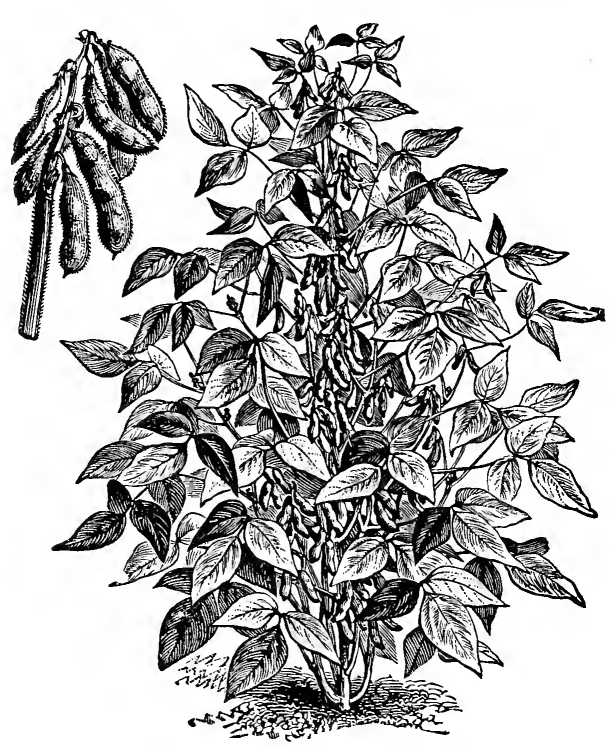

\section{Soy or Soja Beans}

\author{
A Great Drought-Resisting Forage Crop, Producing \\ Immense Quantities of Nutritious Feed, Besides \\ Being an Excellent Soil Improver.
}

SOY BEANS have been cultivated extensively in all latitudes, and by many farmers are preferred to Cow Peas, both for their larger yield of beans, and the fact that they are easier to gather. At the North Carolina Experiment Station, where Soy Beans and Cow Peas were grown under similar circumstances, the yield of hay from Soy Beans was more than twice that of Cow Peas. They are more upright growth, and can be easily cut, and there is not as much trouble in saving and curing, while the quality of the hay is fully equal to that of Cow Pea hay.

Soy Beans can either be sown broadcast or in a drill at the rate of 1 to $1 \mathrm{r} / 2$ bushels per acre if desired for hay; or planted in rows $2 \mathrm{r} / 2$ feet apart and cultivated the same as for corn if desired for crop of beans. For the latter purpose it is not well to allow them to become too ripe, as the pods burst open and many beans are lost.

Medium Soy Beans The best for this latitude and Tennessee for crop of beans, as well as forage. Qt. 15c, pk. 65c, bu. $\$ 2.00$, bags included. Price fluctuates.

Velvet Beans A Famous New Forage and Soil-Improving Plant. Velvet Beans are pronounced by experienced agriculturists of greatest value, the vines and beans make the most nutritious feed, and as they make a most rapid growth, are destined to become universally popular. The vines and roots are rich in nitrogen, making a most valuable soil-improving crop, and they produce enormous crops for forage or soil improving. They do not mature seeds except in extreme Southern latitudes. Plant in May or June at the rate of $11 / 2$ pecks to the acre, in drills five feet apart. They soon make a healthy growth, completely covering the ground with a mass of vines. Pkt. $10 \mathrm{c}$, postpaid; qt. $15 \mathrm{c}$, postpaid $30 \mathrm{c}$; pk. $90 \mathrm{c}$, bu. about $\$ 2.75$. Special prices in large lots.

White Navy Beans Planted in June or July, usually make a very profitable crop to grow as shelled white beans for market. Planted in rows three feet apart, dropping two or three beans together a foot apart in the rows. Cultivate early, as they grow rapidly; but do not work them while the dew is on the foliage. Do not cultivate after they begin to blossom. Qt. $15 \mathrm{c}$, pk. $\$ 1.00$, about $\$ 3.50$ per bu. Special price on large lots.

Dwarf Essex Rape One of the most satisfactory, quick-growing crops for cattle, sheep, and hogs, affording, in from six to eight weeks from sowing, excellent pasture, besides being a splendid soil improver. On account of its quick-growing, splendid-feeding qualities, and being a fine soil improver, it should be largely used in this section and throughout the South, and considering the small expense of seeding and its satisfactory yield, there is no farm which should be without it.

SOWING. Rape can be sown broadcast in the spring at the rate of six to eight pounds per acre, or in the fall four to five pounds. If sown between corn, three to four pounds is sufficient. Spring seeding is possibly the best, as it grows luxuriantly all summer, affording pasture from spring until winter, going to seed the following spring. If sown after wheat or oats the ground should be disced and the seed lightly harrowed in. Price, per 1b. 10c, 10 lbs. at 8c per lb., 25 lbs. at $7 \mathrm{c}$ per lb., $100 \mathrm{lbs}$. and over at $6 \mathrm{c}$ per lb. Bags $20 \mathrm{c}$ each extra.

\section{BUCKWHEAT}

A valuable crop for soil improving, production of grain, and largely used for sowing for bees. The yield of grain is 15 to 25 bushels per acre, and can be used for grinding for buckwheat flour, or the whole grain is splendid for poultry and hog feed, being very fattening. It is best not to sow before June, though July and August are better months in this latitude.

JAPANESE. One of the best sorts with large grain and produces much larger yields than the common buckwheat. $P k$. 40 c, bu. about $\$ 1.30$. Bags 20 c extra.

SILVER HULL. An improved sort. Grain about the size of the common buckwheat, but much better filled and larger yielding. $P k$. 40c, bu. about $\$ 1.30$. Bags $20 \mathrm{c}$ extra.

\section{HAIRY OR SAND VETCH}

(Vicia Villosa.) Recommended for fall seeding at the rate of 1 to $1 \mathrm{I} / 4$ bushels per acre with Barley or Winter Oats. Yields enormously, and can be used either green or dry, similar to clover for hay. This crop has given perfect satisfaction wherever sown. Per 1b. 10c, 10 lbs. 8c, 25 lbs. $7 \mathrm{c}$, $100 \mathrm{lbs}$. and over $6 \mathrm{t} / 2 \mathrm{c}$ per $\mathrm{lb}$. 


\section{Quick Growing Hay and Fodder Plants}

\section{TEOSINTE}

A most Valuable and Enormous Yielding Continuous Cutting Forage Crop. We strongly recommend this to be generally sown, as it will furnish a continuous daily supply of most nutritious green food for horses and all kinds of cattle all through the summer. It also makes splendid dry fodder, yielding enormously and being more nutritious and even better relished by all kinds of stock than corn fodder. In appearance it somewhat resembles Indian Corn, but the leaves are much larger and broader and the stalks contain sweeter sap. It stools out enormously after being cut, as many as forty-five stalks having been grown from a single seed. Sow in May or June, at the rate of two to three pounds per acre, in drills $3 \mathrm{r} / 2$ to 4 feet apart. Oz. $10 \mathrm{c}$, $1 / 4$ lb. 20 c, 1b. 50 c. By mail, postpaid, 60 c.

\section{Millets}

\section{Prices given here are those ruling January 1st. \\ Pearl or Cat Tail Millet}

\author{
Also called Pencillaria.
}

Makes a Splendid Continuous Cutting Forage Crop, either for Green Food or Hay. Farmers in the far South largely depend on Pearl Millet for green food and fodder for all kinds of stock. The enormous yields which are continuously cut four or five times during the season are used for both green and dry feeding, and as it yields so largely, it is very highly prized. It grows ten to twelve feet high, but cutting should commence when a height of $2 \frac{1}{2}$ to 3 feet is attained. After being cut it will stool out enormously, becoming much thicker, makes a rapid growth, and will afford three or four large cuttings during the season. It is very nutritious and is relished by all kinds of stock. It should not be sown until about May. If sown broadcast twenty to thirty pounds should be used, but quicker growth and more frequent cuttings will be obtained if sown five pounds per acre in drills three feet apart and cultivated occasionally. Price, per $1 \mathrm{~b} .15 \mathrm{c}, 10 \mathrm{lbs}$. and over 10c per $1 \mathrm{~b}$., 50 lbs. 8 c per $1 \mathrm{~b}, 100$ lbs. at $7 \mathrm{c}$ per lb. Bags extra.

German Millet Choice Southern Grown. The true German Millet, when properly grown and handled, makes an enormous yield of most nutritious feed, and without impoverishing the soil to any great extent. Sow thickly, about one bushel per acre, and cut while it is in bloom, before the seed hardens in the head. Sow when the weather gets warm in May, or any time during summer until the end of July. Two crops can be seeded and grown during the summer on the same land. Price (January 1st), pk. 40c, bu. \$1.35. Special prices on request.

Hungarian (Panicum Germanicum.) For good low grounds on rich soil, this makes even a more valuable crop than German Millet. It is considered equal in nutritious qualities to Timothy hay. It is very important, in procuring Hungarian Millet, to get the true seed as common Millet resembles it very closely, and is frequently found mixed with Hungarian. This lessens both the yield and the value of the crop. Sow from the first of May to the end of July at the rate of one bushel per acre. Price, about $40 \mathrm{c}$ a pk.; $\$ 1.30$ per bu. Write for current prices.

Kaffir Corn The grain makes most nutritious feed, and can be used for both stock and poultry. Kaffir Corn is of vigorous growth, and can be cut twice during the season if desired for fodder, and will be found most nutritious and very fattening. When used by itself, use from three-quarters to one bushel per acre broadcast. It can be sown in connection with Cow Peas broadcast at the rate of a peck of Kaffir Corn to a bushel of Cow Peas to the acre, and if these are used together, the Kaffir Corn helps to hold the Cow Peas off the ground, and causes a larger growth. Both can be cut together; they are easily cured, and make an enormous yield of the finest quality feed. White Kaffir Corn, 1b. 10c, pk. 35c, bu. (50 lbs.) about $\$ 1.00$. Current prices on request. Bags $10 \mathrm{c}$ each extra.

Broom Corn A very profitable crop, and can be grown in Kentucky remarkably well. It is comparatively easily cultivated, will grow on any land that is suitable for corn, and there is usually an unlimited demand for any amount. Usually produces at the rate of a ton to three or four acres of land. The seed is useful for feeding stock, being nutritious and fattening. Culture.-Sow the seed in drills three feet apart at the rate of from three to five pounds per acre, thinning out to about three inches apart, so as to leave seventy stalks to the rod. Cultivate same as corn.

OKLAHOMA DWARF. An early variety of dwarf, robust growth, bearing long, well-fibred brush. It averages five feet in height, is a great yielder, and seed can be allowed to ripen on the brush without much injury to it. If cut immediately after the brush is pulled it makes very fair feed for stock. Per pkt. 10c; postpaid; $1 \mathrm{lb}$. 15c, postpaid 25c; $5 \mathrm{lbs}$. 50c, bu. (45 lbs.) $\$ 2.50$.

IMPROVED EVERGREEN. An excellent variety of good length; has fine, straight straws, and of greenish appearance after being cut. This variety commands the highest market price. Pkt. 10c, postpaid; lb. 10c, 5 lbs. 45 c per lb., bu. (45 lbs.) $\$ 2.00$. 
The Cheapest, Quality Considered. The Most Available Plant Food. Finest Mechanical Condition. The Most Salisfactory Results.

By purchasing direct from us you save an agent's commission and get the Highest Grade Fertilizers at the Lowest Price. Prices given below are Net Cash f. o. b. Louisville. Car loads quoted delivered to any point 'on request. Half a ton sold at ton rates.

ACME BRAND

POTATO AND TOBACCO FERTILIZER.

Per bag (125 lbs.) \$1.90. Per ton $\$ 28.50$. GUARANTEED ANALYSIS.

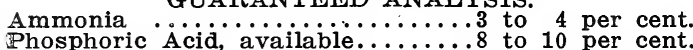
Phosphoric Acid, available........8 to 10 per cent. (Potash in this brand ail from high grade sulphate.) Especially prepared for Irish and Sweet Potatoes, Tobacco, and other crops requiring a good percentage Tobacco, and other crops requiring a good percentage
of potash. On Irish Potatoes it will make large crops of smooth, good keeping and cooking quality potatoes. Use 800 to 1,000 pounds broadcast, or 500 pounds per acre in drills. If used with stable manure, broadcast the manure and use 400 pounds of pounds per acre will give good results, producing a large quantity of smooth, good keeping roots.

On Beets, Radishes, Salsify, Parsnips, Carrots, Dounds per acre, mixing with the soil. For Tobacco pounds per acre, mixing with
200 to 400 pounds per acre.

\section{ACME BRAND}

PURE RAW BONE MEAL.

Per bag (125 lbs.) $\$ 2.00$. Per ton $\$ 30.00$. GUARANTEED ANALYSIS.

\begin{abstract}
Ammonia $\ldots \ldots \ldots \ldots \ldots \ldots \ldots 4$ to 5 per cent. Phosphoric Acid available......22 to 25 per cent. Equal to Bone Phosphate.......48 to 50 per cent. This is the finest Pure Raw Bone Meal made es-
pecially for us by one of the largest packing-houses in the country of pure, untreated green bone. It is in fine mechanical condition, and equal to any bone offered anywhere. Use 200 to 300 pounds broadcast.
\end{abstract}

\section{ACME BRAND}

SPECIAL TRUCKERS' FERTILIZER.

Per bag (125 lbs.) $\$ 1.80$. Per ton $\$ 27.00$. GUARANTEED ANALYSIS.

Ammonia $\ldots \ldots \ldots \ldots \ldots \ldots \ldots \ldots . . . \ldots \ldots$ to 4 per cent. Phosphoric Acid, available........ Made from a fine animal bone basis and prepared especially for quick growing crops, such as Peas, Beans, Early Corn, Melons, etc., and will give fine Beans, Early Corn, Melons, etc., and will give fine results on any garden crop, and we unhesitatingly in hills or drill, 600 to 800 pounds broadcast.

\section{ACME BRAND}

HIGH GRADE VEGETABLE FERTILIZER. Per bag (125 lbs.) \$2.00. Per ton $\$ 31.00$.

$$
\text { GUARANTEED ANALYSIS. }
$$

Ammonia $\ldots \ldots \ldots \ldots \ldots \ldots \ldots \ldots$ to 5 per cent. Phosphoric Acid, available.......10 to 12 per cent. Potash, actual .............. This fertilizer is especially prepared and recommended for all vegetable crops. It gives most excellent results on Cabbage, Lettuce, Onions, and all crops requiring a large percentage of Ammonia and Potash. Use 300 to 400 pounds per acre in hills or Potash. Use 300 to 400 pounds per acre in hills or
drills, or 600 to 800 pounds per acre broadcast, mixing it a little with the soil. It is a good substitute for stable manure, or can be used in connection with it.

$$
\text { ACME BRAND B. B. } P \text {. }
$$

BLOOD, BONE, AND POTASH FERTILIZER. Per bag (125 lbs.) \$1.60. Per ton $\$ 25.00$. GUARANTEED ANALYSIS.

Ammonia $\ldots \ldots \ldots \ldots \ldots \ldots \ldots 2$ to 3 per cent. Phosphoric Acid, available.........10 to 12 per cent. Potash, actual ................ A good fertilizer for general use, either on farm or garden crops, and can be used with or without manure. It will give excellent results to Peas, Beans, Melons, Cucumbers, Tomatoes, early Roasting Ears, and Sugar Corn. Use 200 to 400 pounds per acre in hills or drills. For Millet and quick growing fodder crops use 300 to 400 pounds per acre broadcast.

\section{ACME BRAND}

WHEAT AND CORN FERTILIZER.

Per bag (125 lbs.) \$1.50. Per ton $\$ 23.50$. GUARANTEED ANALYSIS.

Ammonia ................. 1 to 2 per cent. Phosphoric Acid, avallable.......10 to 12 per cent. Potash, actual ................. of Corn, Wheat, Oats, and other grain crops but gives splendid after-results on grass and clover. It is of permanent improvement to soil and leaves the land in better condition for any other crop that may follow the grain crop. Use 200 to 400 pounds per acre in hills or drills, and when broadcasted use 400 to 500 pounds per acre, harrowed in. For corn, if to pou hill, use one handful to two or three hills, scattering it somewhat so as not to let the seed come in direct contact with the fertilizer.

\title{
Acme Complete Grass Grower
}

\author{
Per Bag (125 lbs.) $\$ 2.60$. Per Ton $\$ 40.00$. \\ Especially High Grade for Grass and Grain Crops.
}

A mixture of 1,500 pounds Pure Raw Bone Meal, 200 pounds of Nitrate of Soda, and 300 pounds of Muriate of Potash. Analysis: Ammonia, 5 to 6 per cent; Phosphoric Acid, 16 to 18 per cent; Potash, 7 to 8 per cert.

There is a constant and increasing demand for a high grade permanent fertilizer for grass and grain crops, and this brand can not be excelled in quality. Compare for one minute the high per cent of plant food with the cost per ton with that of cheaper food with the cost per ton with that of cheaper
brands offered. 50 pounds of this fertilizer contains more plant food than 200 pounds of the ordinary commercial wheat and grass fertilizers so commonly sold, and will give better results. We unhesitatingly recommend it for grass, grain, corn; in fact any long growing crop as being cheaper, more beneficial, and more lasting than cheap brands. For best on grain, 300 to 500 pounds on grass, 50 to 100 pounds on corn. Smaller quantities, however, can peunds on corn. and bear in mind it contains four times the plant food that cheap mixtures contain.

\section{Wood, Stubbs \& Co.'s Lawn and Garden Fertilizer}

A complete and concentrated manure for making and sustaining fine lawns. It will improve the grass wonderfully, giving it a beautiful green color. For wonderfully, giving it a beautiful green color. For feet $(12 \times 25)$, or 600 pounds per acre, working in and mixing in the soil. As a top dressing in the winter or early spring, apply at the rate of 5 pounds for 500 square feet, or 400 pounds per acre. The best time to apply as a top dressing is before a rain or snow. Price, 5 lbs. 30c, 10 lbs. 50c, 25 lbs. $\$ 1.00$, 50 lbs. $\$ 1.75,100$ lbs. $\$ 3.00,200$ lbs. $\$ 5.00$, ton $\$ 45.00$.

\section{GROUND LIME}

A great deal of interest is being manifested in the use of Lime, especially for Clover and Alfalfa fields, all over this section.

We have made arrangements to supply a high grade Ground Lime which is made from rock analyzing approximately 98 per cent Carbonate of Lime. This is in fine condition for applying, ranging from powdered up to small granulated particles, and will supply the needed lime to ground for a number of years with one application.
There is not the danger in the use of this Ground Lime that there is in the use of Slaked Lime. It can be applied at the rate of 1,000 to 2,000 pounds per acre with excellent results.

Price, per ton $\$ 7.00$ bags included; 5 tons at $\$ 6.00$ per ton, bags included; car load lots $\$ 4.00$ per ton, sacks to be returned.

special prices quoted to any point, freight pald, on request. 


\section{Grass, Clover, and Grain Seeders}

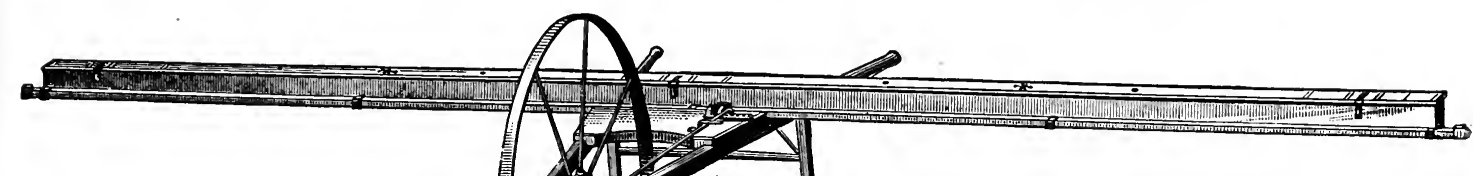

\section{Holmes' Wire-Rope Wheelbarrow, Grass and Clover Seed Sower}

Distributes evenly, accu= rately, more quickly and better than other styles of Seed Sowers
HOIMIS' WIRE-ROPE WHFEIBAREOW SFEDER. The most accurate machines for sowing Clover, Timothy, and light grass seeds. They run easily and sow evenly in windy weather, the seeds being dropped through small holes underneath the trough, which is 14 feet long. Quantity is easily gauged which mas leet be quickly thrown out of gear. This new seer is constructed on up-to-date prinThis new seeder is constructed on up-to-date prinwood to avoid wearing. It does not injure or bunch wood to avoid wearing. It does not injure or bunch seeders. Weight 40 to 50 pounds.

Plain Seeder. Sows small seeds like Clover, Timothy, and other heavy seeds. Price $\$ 7.00$.

Combined Seeder. Sows small seeds like Clover and Timothy, as well as light seeds such as Orchard Grass, Blue Grass, etc. Price $\$ 8.00$.

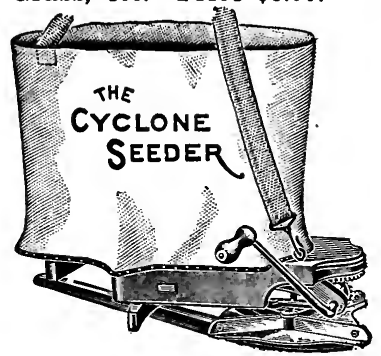

Cyclone Seeder

CYCIONE BROADCAST SEEDER. Simllar to Premier except that the bottom of the seeder is wood and the distributing wheel heavy-coated iron. Thousands of these are in use with perfect success. Adapted to all kinds of grain and heavy grass and clover seeds. Price $\$ 1.25$.
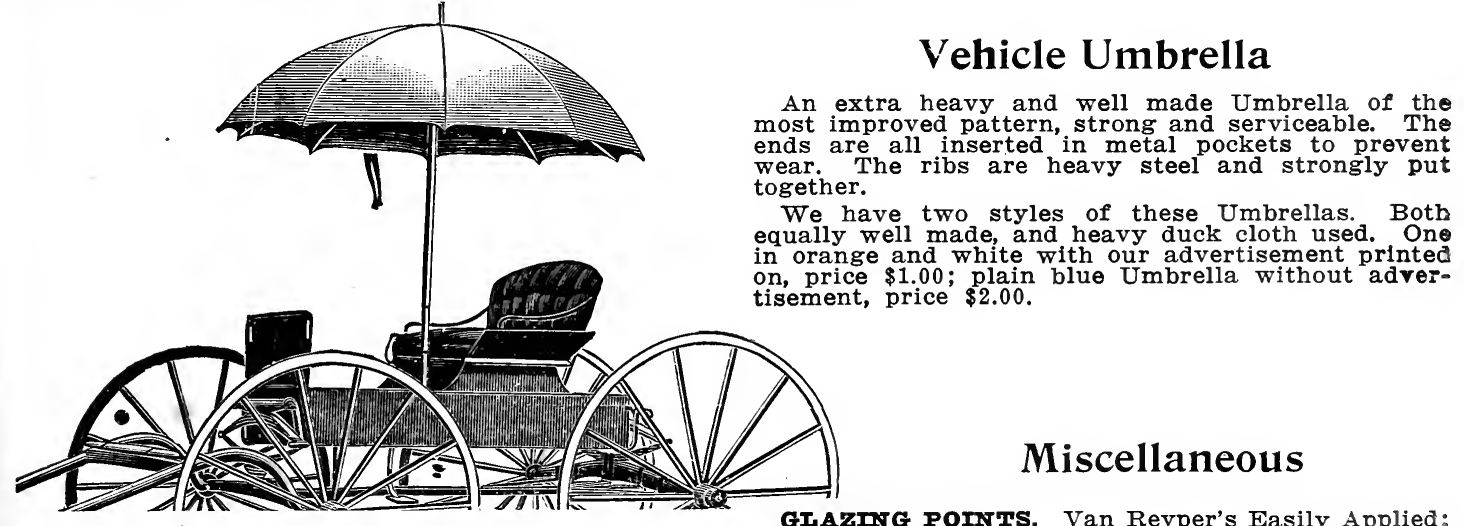

Painted Pot Labels

Per 1,000$$
\text { ( }
$$

CAHOON BROADCAST SFEDER. The standard broadcast seeder and one of the best manufactured. Sows all kinds of grain, Clover, Timothy, and heavy seeds. Very simple in operation and sows 4 to 6 acres an hour at a common walking gait. Distributes seeds uniformly in one-fifth the time required by hand. Circular on request. Price $\$ 3.00$.

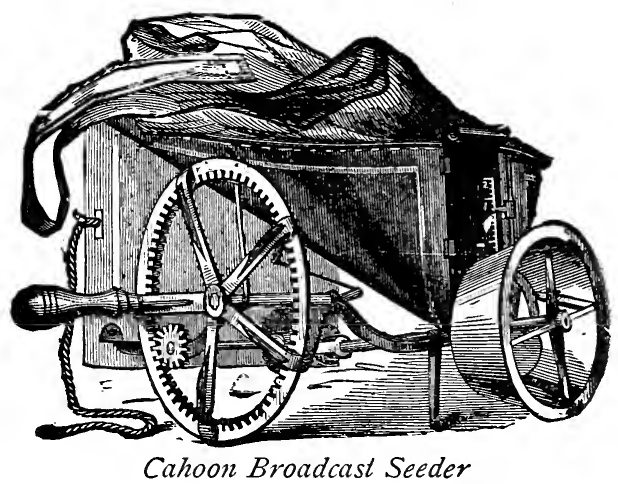

PREMIFR BROADCAST SFEDER. A stronglymade, neat, compact broadcast seeder which is very easy-running and not liable to get out of order, as all of the working parts are malleable castings. Does excellent work and guaranteed to give satisfaction. Capacity not quite as large as the Cahoon. Price $\$ 1.25$.

\section{Vehicle Umbrella} most improved pattern, strong and serviceable. The ends are all inserted in metal pockets to prevent wear. The ribs are heavy steel and strongly put together.

We have two styles of these Umbrellas. Both equally well made, and heavy duck cloth used. One orange and white with our advertisement printed tisement, price $\$ 2.00$.
An extra heavy and well made Umbrella of the

\section{Miscellaneous}

GIAZnNG POINTS. Van Reyper's Easily Applied. no rights and lefts. Per $1,000,75 \mathrm{c} ; 5,000$ and over at $60 \mathrm{c}$ per 1,000

SCOIIAY'S PUTTY BUIB. For applying liquid putty on sash or greenhouses. Each $\$ 1.00$

BONE CUTTYR AND SHEII CRUSHFR. thoroughly satisfactory machine, well constructed, thoroughly sat to a table or box. Price, each $\$ 5.00$. can be clamped to a table or box. Price, each \$5.00. bushel. \$1.10 per dozen. Special price on large quantities.

BFRRY CRATrS. One quart boxes, hold six gallons. Each 20c; per dozen $\$ 2.00$. Price on 100 and 1,000 lots on application. 


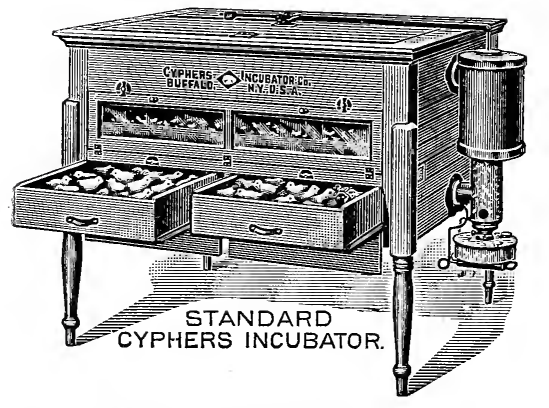

\section{Incubators and Brooders}

\author{
Self-Regulating, Self-Ventilating, the Easiest to Manage, the \\ Most Reliable.
}

We carry complete stocks of well-known Cypher's Incubators and Brooders, and the New Model Incubators and Brooders. Our prices are the same as factory prices, so you save the freight. Manufacturers put them out under a positive guarantee to hatch as large a percentage of fertile eggs as any other machines offered, and in case they are not as represented, we will take them back if in good condition, less reasonable wear, and immediately refund price for same.

NEW MODEI INCUBATORS. Made of the finest material and constructed in the best manner so as to give perfect results in incubation, as well as stand the strain of years. A Model Incubator, if properly handled, will last a lifetime, and there is no machine that has a better reputation for larger hatches and easiness in operation than these. The 1909 machines have a good many improvements, such as flame reducers, improved heating device so that in the hands of a careless operator the heat is self-regulating. Complete catalogue free on request.

Size.

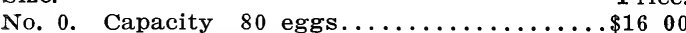

No. $1 . \quad$ Capacity 150 eggs...................2 00

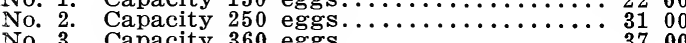

MODEL COIONY BROODERS. These are without a doubt the best and most satisfactory made by any company. They are equipped with all modern devices for heating regulation, can be easily cleaned, and will prove more satisfactory for rearing chicks than any brooder on the market. In addition to furnishing sufficient heat and shelter for the small chick it can be used as a colony house until the pacity, 100 chicks; Price, $\$ 15.00$.

\section{Poultry Foods, Bird Seeds, Etc.}

BIUE RIBBON CHICK FOOD. A complete food for young chicks, combining all elements for growth and development. Combined from corn, wheat, Kaffir corn, oats, millet, bone, and charcoal. $10 \mathrm{lbs}$. $35 \mathrm{c}, 50$ lbs. $\$ 1.40,100 \mathrm{lb}$. bag $\$ 2.50$.

BIUE RIBBON DEVELOPING FOOD. A combination of grains and seeds free from grit, shells, and low priced material. A scientific preparation for developing fowls and the cheapest food, considering developing fowls and the cheapest food, considering value. Made from corn, wheat, barley, oats, buckwheat, sunflower, oil
$\$ 1.25,100$ lb. bag $\$ 2.25$.

BLUE RIBBON SCRATCH FOOD. A very supergor food for general feeding, combining diversity of grains without grit, shell, or cheap ingredients. corn. 50 lbs. $\$ 1.25,100 \mathrm{lb}$. bag $\$ 2.25$.

PIGEON FOOD. A combination of grain, peas, and seeds. The finest, most perfect food on the market. 50 lbs. $\$ 1.50,100$ lbs. $\$ 2.50$.

SHORT CUT AIFAIFA. A standard green food invaluable for egg production. Can be fed either with mashed food, used in the trough by itself, and is excellent to scatter in brooders, or where young chicks run. 50 lbs. $\$ 1.00,100$ lbs. $\$ 1.75$.

CHARCOAI. Absolutely indispensable as an aid to digestion, and promotes health of both young chicks and fowls. A little goes a long way. Pound $10 \mathrm{c}, 3$ lbs. $25 \mathrm{c}, 10 \mathrm{lbs}$. $50 \mathrm{c}$.

CRUSHED OYSTER SHELI. Every raiser of poultry, whether large or small, should have a supply of Oyster Shells and use it freely either in poultry yards or where fowls run, as it is absolutely necessary to the development of both bone and for necessary to the development of both bone and for egg production. $5-1 \mathrm{~b}$. pkg. $10 \mathrm{c}, 25-1 \mathrm{~b}$.

MICA CRYSTAI GRIT. One of the most valuable grits that has ever been introduced, improving the condition of all kinds of poultry, keeping them in healthy condition and entering into the formation of the component parts of the shells and yolks of eggs. This is the standard grit of America; recognized by breeders as the best. Price, 5 lbs. 10c, 25 lbs. 35c, 100 lbs. $70 \mathrm{c}$.
CYPHER'S STANDARD TNCUBATORS. Constructed of best material, extra finely finished, and well put together. Has combination of both hen and duck eggs, insulated with asbestos and fire proof. They are easy to clean, every interior part being removable, put together with lock corners and cement-coated nails to prevent joints opening. Will do the work of three or four ordinary cheap incubators.

Price.

No. 1. Capacity 140 hen eggs..........\$21 00 No. 2. Capacity 240 hen eggs............. 3000 No. 3 . Capacity 396 hen eggs.............. 3600 egg incubators.

CYPEFR'S BROODFRS. Can be put together without driving a nail; have extra heavy duck roofing and arranged so that all parts can be readily gotten at for cleaning; heating apparatus and regucan be arranged for an out-of-door house after chicks have passed the brooding stage.

Colony Brooder, for out-door use, self regulating, 100 chick capacity price $\$ 18.00$

Style A. 100 chick capacity, $\$ 15.00$.

Storm King. 75 chick capacity, $\$ 10.00$.
IAUST'S HEAITH GRIT. Stands pre-eminently alone as the only high class grit to the breeder of high class pigeons. It is far superior to ordinary flint, shell, sand, and all natural grits, and is endorsed by the best pigeon breeders and pigeon fanciers all over the United States. Lb. $5 \mathrm{c}, 10 \mathrm{lbs} .35 \mathrm{c}$, 100 lbs. $\$ 2.00$.

CRUSHED OR GRANULATED BONE supplies the lime for shell and other ingredients necessary in the composition of eggs. Scatter about the poultry yard. 5 lbs. 20 c, 25 lbs. 75 c, 100 lbs. $\$ 2.25$.

FINE BONE MEAL. Excellent to aid in increasing egg production, and a splendid feed for young chicks. Should be fed wet, mixed with cornmeal or bran. 5 lbs. $25 \mathrm{c}, 25$ lbs. $75 \mathrm{c}, 100$ lbs. $\$ 2.50$.

GROUND BFFF SCRAPS. To be mixed with wet feed. Fine for keeping poultry in healthy, thriving feed. Fine for keeping pounceasing egg · production. 5 lbs. 25c, 25 lbs. $\$ 1.00,100 \mathrm{lbs}$. $\$ 3.25$.

GROUND MEAT MEAL. A valuable preparation for mixing with wet feed, supplying nitrogenous and fatty ingredients, especially in winter and spring. 5 lbs. $25 \mathrm{c}, 25$ lbs. $\$ 1.00,100$ lbs. $\$ 3.25$.

WOOD, STUBBS \& CO.'S FINE MIXED BIRD SEFD. A combination of the best and highest quality seeds in proper proportions. Cuttlefish with each pound. Lb. $10 \mathrm{c}, 4$ lbs. $25 \mathrm{c}, 10$ lbs. $60 \mathrm{c}$.

CANARY. (Recleaned Sicily.) Lb. 10c, 4 lbs. 25c, 10 lbs. $60 \mathrm{c}$

HEMP. (Imported Russian.) For parrots, pigeons, etc. Lb. 10c, 4 lbs. $25 \mathrm{c}, 10$ lbs. $50 \mathrm{c}$.

RAPE. (Imported.) Not the common article usually sold. Lb. $10 \mathrm{c}, 3$ lbs. $25 \mathrm{c}, 10 \mathrm{lbs}$. $60 \mathrm{c}$.

SUNFIOWER. (Mammoth Russian.) For parrots, pigeons, etc. Lb. $10 \mathrm{c}, 3$ lbs. $25 \mathrm{c}, 15 \mathrm{lbs}$. $\$ 1.00$.

CANADA PEAS. For pigeons. Pk. 60c, bu. \$1.65. MrILET. For young chicks and song birds. Lb. $5 \mathrm{c}, 10 \mathrm{lbs} .25 \mathrm{c}$.

BUCKWHgAT. For poultry, pigeons, etc. Pk. $35 \mathrm{c}$, bu. $\$ 1.20$.

MOCKING BIRD FOOD (Young's). One of the best preparations for mocking birds or other birds with soft bills ever offered, and one which we have found to give thorough satisfaction. Bottles 25c, in bulk, lb., $25 \mathrm{c}, 5 \mathrm{lbs}$. at $20 \mathrm{c}$ per $1 \mathrm{~b}$.

Booklet on Poultry Diseases, Remedies, etc., Mailed Free on Application. 


\section{Poultry Remedies, Egg Producers, Etc.}

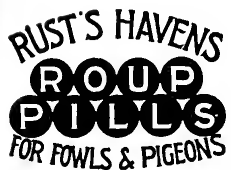

RUST'S FGG PRODUCER. One of the best and most satisfactory preparations we have sold for feeding to poultry to increase egg production. Largely increases the quantity of eggs and improves the appearance of the poultry and keeps them in a healthy condition. Price, lb. pkg. $25 \mathrm{c}$, by mail $45 \mathrm{c}$; $21 / 2$-lb. pkg. 50c, 6-lb. pkg. $\$ 1.00,10-1 \mathrm{~b}$. box $\$ 1.50$.

\section{CIIMAX CONDITION POWDFRs. See below.}

ROUP PIIIS. An almost sure cure for roup, given according to directions. We have known almost hopeless cases cured by it. Per box of 50 pills 25c. Mailed on receipt of price.

INTTERATIONAI POUITRT FOOD. A medicated poultry food which gives the most remarkable results ever known, and is the largest seller. It prevents disease, cures chicken cholera, and greatly increases egg production making the chickens grow more rapidly. The small size contains 1,200 feeds. Regular Size, price 25c. Iarge Box, contains 2,500 feeds. Price $50 \mathrm{c}$.

PRATT'S POUITRY FOOD. A well known preparation which has been favorably used all over the country. 26-oz. pkg. 25c, large pkg. $50 \mathrm{c}, 12-1 \mathrm{~b}$. pail $\$ 1.35$.

INTFRNATIONAI IICE KIIIFR. One of the best preparations for this purpose, put up in packages holding one pound, with perforated top so that it can be dusted on the fowl or in the nest. Pkg. $25 \mathrm{c}$.

IFE'S IICE KIIIFR. The oldest liquid on the market and one of the best. Directions for use on each package. Qt. 35c, 1/2 gal. 60c, gal. $\$ 1.00$.

PRATT'S IICE POWDER. An effective remedy for use on fowls and in poultry houses. In packages with perforated tops. Price 25c.

PRATT'S ROUP POWDER. An effective and sure cure for roup or colds. Pkg. 25c.

RUST'S IICE KIIIER, for applying in poultry houses and on perches and in nests. Directions on can. Qt. can $35 \mathrm{c}$, $1 / 2$ gal. can $65 \mathrm{c}$.

CYPHFR'S IICE POWDER. Valuable for using in nests of setting hens, for lice on cattle, horses, besides insects on sheep and dogs. 5-oz. pkg. 10c; postpaid 15c; 15-oz. box $25 \mathrm{c}$, postpaid $40 \mathrm{c}$.

CYPHFR'S ROUP CURE. Positively guaranteed to cure roup in all its forms. It is simply put in drinking water, and prevents colds, and is unequaled for canker, especially in pigeons. Pkg. $50 \mathrm{c}$.

KNOX'S NEST FGGS. Medicated, keeping the fowls free from vermin, and takes the place of the ordinary nest eggs. Each 10c, 3 for $25 \mathrm{c}$, per doz. 75 e.

We carry full lines of Dry Food Hoppers, Shell and Grit Boxes, Drinking Fountains, and other supplies for poultry growers.

\section{Stock Foods}

\section{And Remedies for Diseases, Insect Pests, Etc.}

INTERNATIONAI STOCK FOOD. This is one of the most popular of all stock foods and has possibly the largest sale of any preparation on the market. It is valuable for horses, cattle, sheep, hogs, and all It is valuable for horses, cattle, sheep, hogs, and all other animals, cures and prevents diseases, and paves in feed by aiding digestion and assimilation, purifies the blood, causes new life and strength and
makes stock fat, sleek, and healthy. $11 / 2-1 b$. pkg. $25 \mathrm{c}$, 3 -lb. pkg. 50c, 7-1b. pkg. $\$ 1.00,25-1 \mathrm{~b}$. bucket $\$ 3.00$. Costs one-third of a cent a feed.

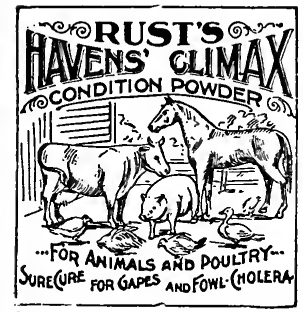

CImAX C ON DITION POWDIRS. A first-class preparation for all kinds of poultry and cattle. A splenpoultry and cattle. A splenother diseases. It tones up the system and greatly improves the plumage after the trying moulting season. It is also a good medicine for hogs, cattle, and horses, and gives splendid satisfaction to our customers who use it. Price, 13-oz. box 25c; if sent by mail $40 \mathrm{c} ; 32-0 \mathrm{z}$. box $50 \mathrm{c}$;
$-1 \mathrm{~b}$. box $\$ 1.00,8-1 \mathrm{~b}$. box $\$ 1.50$.

PRATT'S STOCK FOOD. 7-lb. pkg. 50c, 12-lb. sack $75 \mathrm{c}$.

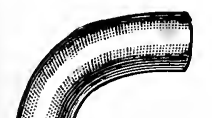

\section{Trowels, Dibbles, Etc.}

FORGFD STHFI TROWFIS, blade and shank made of one piece of steel, finely polished, strong and stout, 5-inch, each 35c;6inch $40 \mathrm{c}$ each.

SOID STrgI TROW FIS, 6-inch, each 20c. ORDTARY GARDFI TROWFIS, 6-inch, each $10 \mathrm{c}$.

TRATSPIATMTRG TROWEIS, 6-inch, each $15 \mathrm{c}$.

TRANSPI.ATYISG TROWIIS, 8-inch, each 5 c.
PRATT'S ANIMAT RFGUTATOR. For horses, , 28-oz. pkg. 25c, large pkg. $50 \mathrm{c}, 25-1 \mathrm{~b}$. bucket $\$ 3.00$.

INTFRNATIONAT COIIC CURE. Per bottle 50c. INTFRNATIONAI HOOF OINTMCNT. Keeps the hoof soft, elastic, and at the same time induces 2 tough, smooth hoof. In tin pails, 11/2 lbs., $\$ 1.00$.

We carry complete stocks of most of the International Food Co.'s preparations.

INTFRIATIONAI GAII CURE. Splendid remedy. Per tin 25c.

INTERNATIONAI WORIM POWDER for horses Pkg. 50c.

ITTERNATIONAT DISTFMPFR CURF. Pkg. 50C. PRATT'S GAIT CURE. Pkg. 25c.

HAMMOND'S CATTIF COMTORT. One of the greatest boons to domestic animals for prevention of the annoying attacks of flies, gnats, and other insects which are troublesome to cattle. An application of "Cattle Comfort" will relieve cattle, horses, dogs, and fowls from the noxious effects of insects and parasites, and is healing to sores. "Cattle Comfort" is not an irritant to the skin, heals sores and scabs, will bring out dead hair, and is soothing and comforting. Circular giving further information on comforting. Circular giving further information on

\section{Rope and Twine}

PIOW IINF, cotton rope, $3 / 8$ inch, per foot $1 \mathrm{c}$. GARDEN IINF, balls about 150 feet, $35 \mathrm{c}$. BUITCEING TWINs, three ply, per bag (5 lbs.) $\$ 1.25$.

BUACHING TWINs, four ply, per bag (5 lbs.) $\$ 1.25$.

BINDgR TWINF (Sisal), 5 lb, balls 50c, 50 lbs. and over at $9 \frac{1 / 2}{\mathrm{c}}$ per lb. Subject to market changes.

RAFrIA; the best material for tying soft-wooded and vegetable plants, largely used for basket and mat making. Per lb. 20c, 5 lbs. and over at $15 \mathrm{c}$ per lb. 


\section{Insecticides and Fungicides}

\section{For Plants, Trees, Seeds, Etc.}

PARIS GREFN. One of the cheapest and most effective poisons for potato bugs and other leafeating insects. It is a strong poison and should be carefully handled. Paris Green is usually applied unadulterated (or if for potatoes, mixed with Bordeaux Mixture to prevent blight), with Dry Powder Guns or Beetle Dusters. (See Implements.) For small applications it can be diluted with Land Plaster (1 lb. of Green to 50 lbs. of Plaster) or water (1 lb. to 100 gallons). For tender foliage double the quantity of adulterants.

BIUE RIBBON BRAND PARIS GREFN. Strictly pure; guaranteed to contain not less than $56 \%$ Arsenious Oxide. This is especially finely ground, for use in Dust Sprayers. It is pure, strong, uniform and absolutely reliable. On account of its fineness and light gravity this Paris Green blows better out of a Duster than coarser ground brands, and is therefore more economical to use, covering a larger surface and is not liable to burn the foliage. It remains in suspension with water longer and sprays better than other makes. We strongly advise the use of Blue Ribbon Brand Paris Green for best results. Price fluctuates. Present price (January ist) $1 / 1 \mathrm{~b}, 20 \mathrm{c}, 1 \mathrm{~b}, 30 \mathrm{c}, 5$ ibs. $27 \mathrm{c}$ per $1 \mathrm{~b}, 50 \mathrm{lbs}$, and over $25 \mathrm{c}$ per lb. Write for prices, stating quantity.

ARSFNATE OF IFAD. One of the most effective poisonous insecticides in paste form yet discovered for leaf-eating insects. It will not scorch, burn, or injure the most delicate foliage, and is better than Paris green for spraying trees, as it sticks better, does not wash off easily, and is just as effective. Use with water, 1 lb. to 40 or 50 gallons. Lb. 30c, $5 \mathrm{lbs}$. and over $20 \mathrm{c}$ per lb., 100 lbs. $16 \mathrm{c}$ per lb.

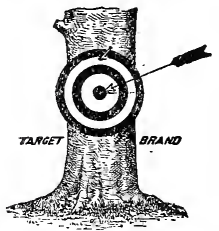

TARGET BRAND SCATE DESTROYER. For San Jose and Oyster Shell scale and all sucking insects. It spreads into all cracks and crevices where other spraying material will not reach, forms an insoluble coatíng which not anly insoluble coating which not tects the tree and keeps it healthy. It is effective and safe, because it has no caustic action, and is not

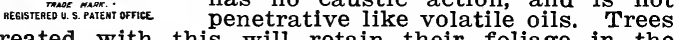
treated with this will retain their foliage in the greater vitality. Target Brand Scale Destroyer greates time and labor does not scale Destroyer injure animal life. It is the most nozzles nor safest, and easiest of all scale destroyers. Qt. 35c, safest, and easiest of all scale destroyers. Qt. $35 \mathrm{c}$, obl. at $50 \mathrm{c}$ per gal.

TARGET BRAND OUICK BORDEAUX. For Blight, Mildew, and all fungous diseases. With a barrel of water and a bag of Quick Bordeaux an amateur can produce a fresh and proper fungicide equal to the very best product. This preparation is recommended by entomologists as superior to home made. 6-1b. packages (making 30 gallons of liquid) $60 \mathrm{c}, 10$-1b. packages (making 50 gallons of liquid) $90 \mathrm{c}$, in $100-1 \mathrm{~b}$. lots at $7 \mathrm{c}$ per $1 \mathrm{~b}$.

TARGET BRAND WFED KIIIFR. For killing grass and weeds on roadways, paths, tennis courts, baseball diamonds, walks, gutters. Destroys roots as well as tops. One gallon with fifty gallons of water is sufficient to cover 100 to 150 square yards, and one or two applications last an entire season. Qt. $45 \mathrm{c}$, gal. $\$ 1.00$, 5 gals. $\$ 4.50,10$ gals. $\$ 8.50$, bbls. $75 \mathrm{c}$ per gal.
FORMAIDFHYDE. For applying to potatoes to prevent scab, and for dipping grain to destroy smut spores. Smut in a growing crop of grain will sometimes reduce the yield 20 per cent, and with an application of Formaldehyde it can be prevented almost entirely. One pint of Formaldehyde diluted with thirty gallons of water is sufficient for dipping potatoes, or one pint to fifteen gallons of water for grain or seeds. Pint bottle 50c.

HAMMOND'S SIUG SHOT. One of the best vegetable insecticides in use. Specially recommended for destroying the Cabbage worm, Potato bug, Tobacco worm, and other insects that prey on vegetation. Gardeners need have no fear about applying this, as it is not dangerous to handle like Paris green, etc. Non-poisonous to human life. Price, $1-1 \mathrm{~b}$. canisters 15c, 5-lb. pkgs. 25c, 10-1b. pkgs. 50c lb. Pamphlet containing full information mailed free.

IFMON OII INSECTICIDE. The very best remedy for house plants, effectually destroying Green has no bad odor, is easy to handle, minew, etc. It water, and can be applied to plants of most delicate foliage without danger. The "Lemon Oil" is a capital wash for dogs; it cures mange, destroys insects, destroy lice and insects by spraying in hen pens and poultry houses. Directions for use on each can
Price, $1 / 2-$ pt. tins 25 c, by mail 35 c, pt. 40 c, by mail $60 \mathrm{c}$, qt. $75 \mathrm{c}$, $1 / 2$ gal. $\$ 1.25$, gal. $\$ 2.00$.

ROSE IFAF EXTRACT OF TOBACCO. A liquid extract of Tobacco which will be found very effecextract of Tobacco which will be found very effective for killing aphis, green fiy, scale insects, lice on plants, and other insects. It is also a splendid sheep used and endorsed by florists and gardeners for applying in greenhouses, hotbeds, etc. Pt. 30c, qt. 50c, gal. $\$ 1.25$, 5 -gal. can $\$ 4.25$.

WHATE OII SOAP. The best and safest remedy for destroying the San Jose Scale and other scale insects, plant lice on vegetables, shrubs, and trees. sects sucking the juices from plants. This is the best brand made from caustic potash and pure fish oil, quality guaranteed. 1-1b. can $20 \mathrm{c}$, 5-1b. cans $75 \mathrm{c}$, $\$ 20.00$.

TOBACCO DUST. One of the cheapest and most ffective remedies for destroying lice and worms on effective remedied for destroying lice and worms on Squashes, and other insects. It is best to dust on young plants when the dew is on, as it will stick young plants when the dew is on, as it will stick
better. Lb. $10 \mathrm{c}, 10 \mathrm{lbs}$. $50 \mathrm{c}, 25 \mathrm{lbs} . \$ 1.00,50 \mathrm{lbs} . \$ 1.50$, 100 lbs. $\$ 2.50,1,000$ lbs. $\$ 20.00$.

TOBACCO STFMs. For fumigating or use as a mulch preventing green fly and other parasites. Per bale (about $400 \mathrm{lbs}$ ) $\$ 6.00$, ton $\$ 25.00$.

SUIPHUR. For Mildew on Roses, Lettuce, and Also valuable for poultry, insects, etc. Lb. $10 \mathrm{c}, 10 \mathrm{ibs} .50 \mathrm{c}$

WHITE HFIIEBORE. A non-poisonous powder for destroying Cabbage worms, bugs, and lice on vegetables. $1 / 4$ lb. $10 \mathrm{c}, 1 / 2 \mathrm{lb}$. $15 \mathrm{c}, 1 \mathrm{lb}$. 25c; postage at the rate of $16 \mathrm{c}$ per $1 \mathrm{~b}$.

Lawrence County, Tenn., Feb. $10,1908$. the Blue Ribbon Seed.

Gibson County, Tenn., March 27, 1908.

Everything sent me was perfectly satisfactory, and I thank you for your prompt attention.

Boyle County, Ky., March 26, 1908.

Please send us two tons Potato Fertilizer. We bought some of you last year for a customer of ours, who is from England. He obtained fine results from the use of same. W. S. HILTON.

Pocahontas County, Iowa, March 10, 1908

I have just completed a $\$ 10,000$ residence here and will ask you to send me two and a half bushels of your $B$. Evergreen Lawn Grass. My neighbor purchased this seed some years ago for his lawn and had such good success that I know what it will be and don't want any other.

FRANK FAIRBURN, Vice-Pres. Fairburn state Bank.

Linn County, Iowa, May 2, 1908. cery satisfactory. 


\section{Dry Powder and Insecticide Distributors}

\section{CHAMPION DRY POWDER GUNS}

An Invaluable Distributor of Insecticides and Fungicides in the Orchard, Vineyard, Garden or Field

The Champion Gun has received unqualified endorsement and given universal satisfaction wherever used. It distributes without adulteration, dry Paris Green, London Purple, Hellebore, Lime, dry Bordeaux Mixture, Tobacco Dust, and other insecticides evenly and with only one-tenth of the labor, time, and cost required by other devices and any other methods, and with far greater efficiency. It will cover one or two rows at once as fast as a man walks, can be regulated easily for quantities and will do as much work in a day as a horse-power sprayer. Champion Guns have been used extensively in potato and tobacco sections and have always given perfect satisfaction. They are adaptable to any and all purposes and do efficient work on potatoes, cabbage, tomatoes, etc., in fact all garden and field crops. Extension tubes enable the gun to be used on fruit and shade trees or in the vineyard. Among potato and tobacco growers they

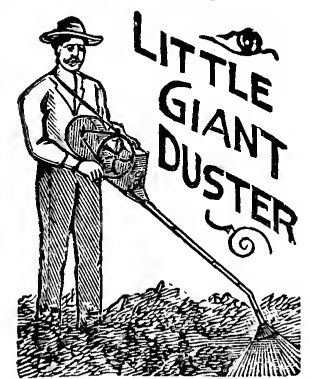

have become almost indispensable, perhave become almost indispensable, perrapid manner without waste of material, and by far the most economical instrument ever offered for applying remedies for insects. Circulars giving further information on application. Price, with all attachments, $\$ 8.00$.

\section{Little Giant Duster}

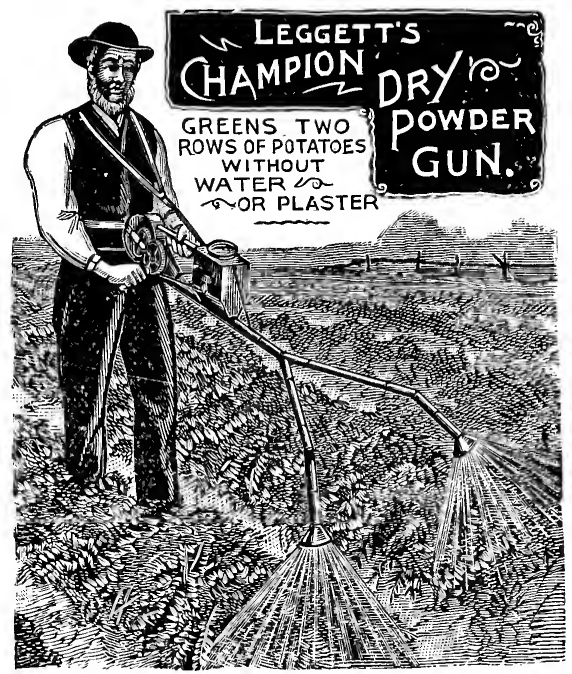

This is made on the same principle as the Champion Dry Powder Gun, but there are slight differences in the construction, and it is offered to supply a demand for a lower priced implement. The principle of its operation is about the same as the Champion Gun, though there is a difference in the gearing. It does about the same work as the Champion Gun, though for general work we would recommend the Champion Gun. Price $\$ 6.00$ each.

\section{The "Beetle" Four Row Potato Duster}

(Horse Power)

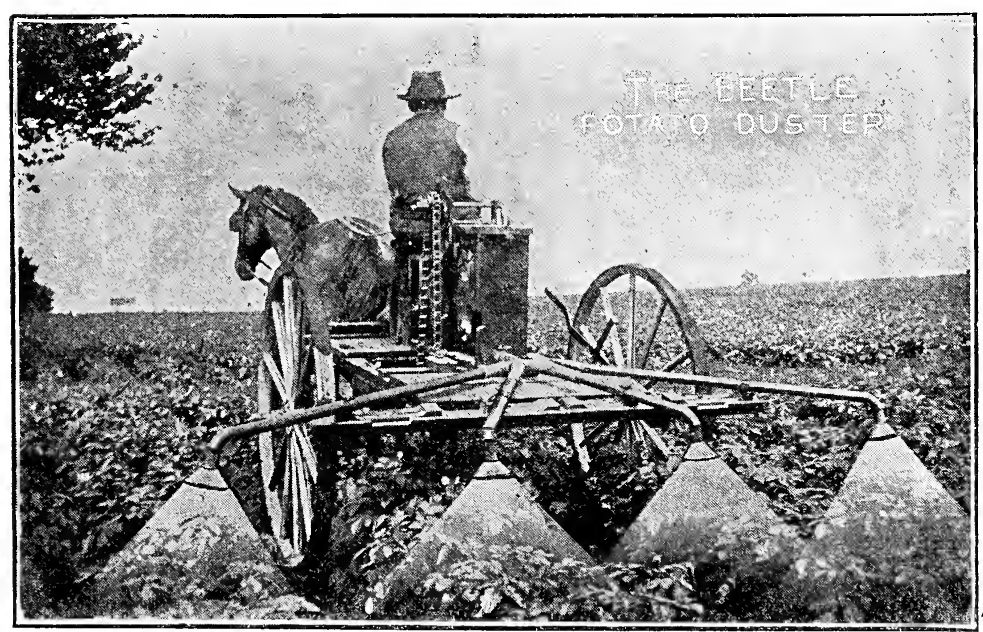

"Beetle" Four Row Horse Power Potato Duster
This is constructed on the same principle as the Champion Paria Green Gun which has been in such general use. Four rows may be dusted at once as fast as a horse walks, covering 20 to 40 acres per day. Everything is in favor of the dry process. A man with one horse can accomplish as much horse can accomplish as much with this duster as would beying, quired with two horses spraying, for instead of hauling fifty galGreen, three pounds dry with a Beetle Sprayer will cover the same ground. Again the dry process is more effective, for the dust is blown through the vines so that underneath as well as the that underneath as well as

upper surfaces are reached. In practical operation the reserits capacity is 50 lbs. The tubes and nozzles may be raised or lowered, and these as well as the wheels are adjustable for wide or narrow rows. The fan and agitator are controlled by a clutch.

The Beetle Duster saves time, labor, and material, and will at once commend itself to large potato growers. As Paris Green 18 applied here now it takes three men in a wagon with two Champion Guns, one driving and two working the guns out of the back. With this implement one man can do the work of three. Price, complete, $\$ 60.00$.

Special Note Beetle Potato Dusters are used by nearly all the large potato growers in this many of our customers say they would not part with theirs for double the cost if another could not be obtained.

ACMI POWDER BEIIOWS. A simple and practical implement for applying all powdered insecticides, such as Paris Green, Hellebore, Insect Powder, Slug Shot, etc. It is very effective in the destruction of potato bugs, currant worms, melon bugs, tobacco worms, cabbage worms, and other insects that affect plants. It will apply powder at the top sides or underneath the leaves of plants. Acme Powder Guns wood handles, best leather for the bellows, and an extra elbow is furnished to tilt the funnel for getting under the leaves of the plants and shrubs. It is easy to operate, light, serviceable, and the most useful to farm or garden. Every farmer should have one. Single Acme Bellows, each \$1.00; Double Acme Bellows, each, $\$ 1.75$. 


\section{SPRAYERS_Compressed Air and Knapsack}

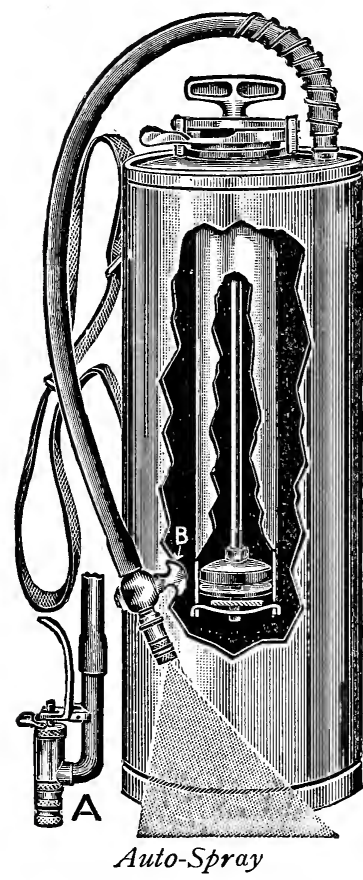

\section{The Auto=Spray-A Self-operating Automatic Sprayer}

This machine is especially desirable for spraying insecticides, fungicides, etc., as well as being useful for various household and farm purposes. A few strokes of the plunger into the air chamber will compress enough air to discharge the entire contents of the can and make a continuous spray for nine minutes, or if desired, wil throw a single stream thirty leet high. This ruptedly long rupts four holds four gallons, but it should not be over two-thirds full of solution ready for spraying. It can be used with all classes of material and will last for years. The cylinder is made of galvanized iron and the pump strongly and rigidly made. It can be carried in the hand or used as a knapsack sprayer.

Extension pipes can be fitted to the pipe so that it can be used for tall trees or shrubs. An automatic valve called Auto Pop has been added, and machines equipped with this allow an instantaneous discharge, and the spray is in perfect control. We advise ordering with Auto Pop attachment. All machines are warranted against defective material or workmanship, and will do effective and satisfactory work.

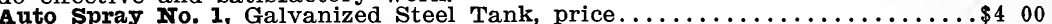

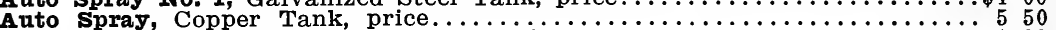

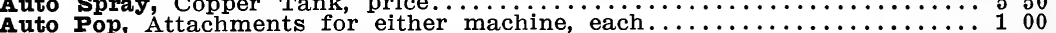

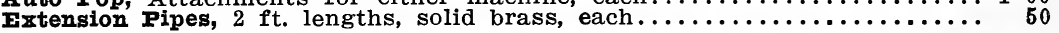

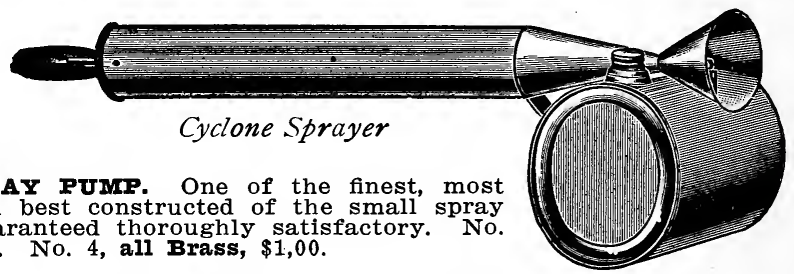

CYCIONE SPRAY PUMP. One of the finest, most easily operated, and best constructed of the small spray pumps offered. Guaranteed thoroughly satisfactory. No. 1 , all Tin, price 50c. No. 4, all Brass, $\$ 1,00$

IOWEIT GIASS TANK SPRAYER. Similar in construction and operation to the above, except that it has a glass reservoir instead of metal. Will hold corrosive liquids and the reservoir will not rust. The glass reservoir consists of a Mason fruit jar, hence if broken can be easily replaced. Price 50c each.

SMAII TIN SPRAYFRS. Constructed on the same principle as Cyclone Sprayers. Price, each $30 \mathrm{c}$.

IOWEIT DRY POWDFR SPRAYIR. This is constructed on the same principle as the liquid atomizers, having a reservoir and a plunger which forces the insecticide out, scattering it in a fine impalpable powder. It is the most economic arrangement we have ever seen and thoroughly satisfactory for seen and thoroughiy

Price 75 cents each.

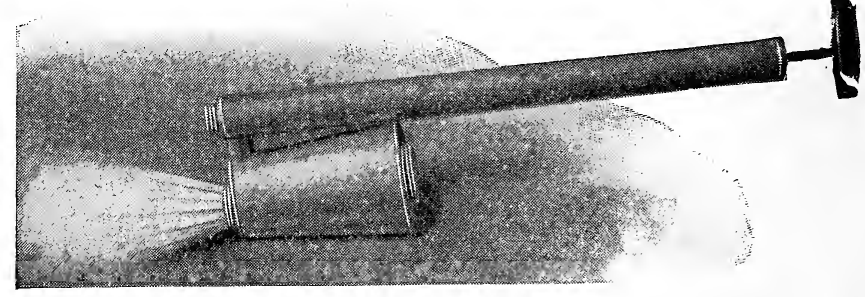

Lowell Dry Powder Sprayer

\section{BRASS SPRAY PUMPS}

We carry other lines of spray pumps in various sizes for spraying, whitewashing, vehicle washing, etc., and will send on request Illustrated Catalogue Free. This catalogue contains full directions of How, when, and why to spray, giving formulas for use of various insecticides and fungicides. Prices given below are net and much lower than the manufacturers' list prices.

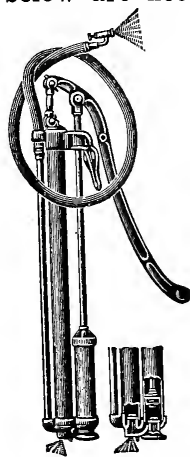

Meyers' Improved Brass Barrel Spray Pump No. 302
MYFRs' D O U B I F A C T I T G SPRAY PUMP No. 302. All working parts brass. No leather valves to get out of order; has agitator at get out of order; has agitator atto fine, coarse, or solid stream. One of the best pumps for extensive spraying and whitewashing. Price $\$ 8.00$.

MYFRS' IMPROVFD BAREFI SPRAY PUIMP No. 305. Has bronze ball valves and brass seats, hemp packed plunger. Complete with $5 \mathrm{ft}$. of half-inch three-ply discharge hose and Myers' graduating vermorel nozand Myers' gradu.

MTFES, PFRFFCT B U C T T SPRAY PUMP To. 315. Works without lever, straight lift and push. Has 2-inch air chamber and spray can be continued several minutes; produces continuous spray, fine, coarse, or solid stream; agitator attachment. Price, complete, $\$ 4.50$.
MYFR' IFVFR BUCKFT SPRAY PUMP No. 324. New pattern with $1 \frac{1}{4}$-in. cylinder. Can be used in bucket or attached to top of barrel; has vermorel nozzle, throwing fine or coarse spray and single stream; patent agitator. Price, complete, $\$ 4.50$.

MYFRS' IMPFRIAT SPRAY PUMP No. 325. With patent agitator, fitted with malleable foot rest, graduating vermorel nozzle, and return overflow cap. Will throw a solid stream 50 feet. Useful for spraying, sprinkling, whitewashing, etc. Price $\$ 3.50$.

ITTTIP GIANT BRASS SPRAY PUMP No. 327. Complete with hose and graduating spray and agitator attachment. Price \$3.25.

If the above Sprayers do not meet your requirements, WRITE US. 


\section{PLANET JR. TOOLS}

Complete lllustrated Catalogue Free on Request

Our Net Prices 50c. Less on each Tool than Regular Planet Jr. Prices

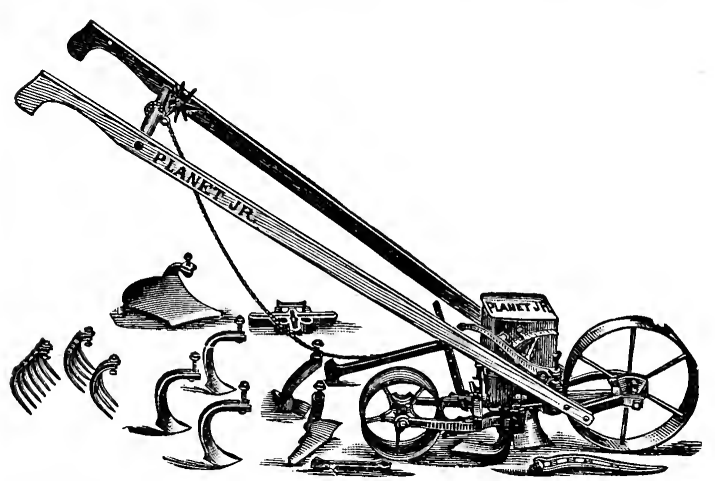

PLANET JR.No. 4-Combined Hill and Drill Seeder. Price complete, \$11.50; without Rakes, \$ro.50. As Drill only, $\mathbf{\$ 8 . 5 0}$

\section{PLANET JR. WHEEL HOES}

No. 11. Double wheel Hoe, has 14 cultivating

and weeding tools. Price............... \$ 50

No. 12. Double wheel Hoe, has 8 cultivating and weeding tools. Price.................

No. 12 A. Double Wheel Hoe, without plows

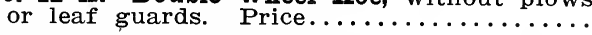

No. 13. Double Wheel Hoe, with 2 weeding hoes only. Our net price..................

No. 14. Double Wheel Disc Hoe. Cultivator and plow. Price.$\ldots \ldots \ldots \ldots \ldots \ldots \ldots$ No. 16. Single Wheel Hoe, has 7 cultivating and weeding tools and garden plow........ No. 17. Single wheel Hoe, with 6 weeding and

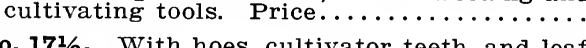
No. 171/2. With hoes, cultivator teeth, and lea No. 18. Single wheel Hoe, with hoes only.... No. 38. Single Wheel Disc Hoe. Cultivator and plow. Price..$\ldots \ldots \ldots \ldots \ldots \ldots \ldots$

Fire Fly Garden Plow. A splendid tool for small gardens; opens and throws a furrow 4 to 6 inches wide. Price................ 225

Farmers 2No. 19. Has 6 tools for cultivating

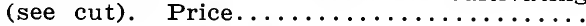

650 550 425 750 535 450 400 300 650 350

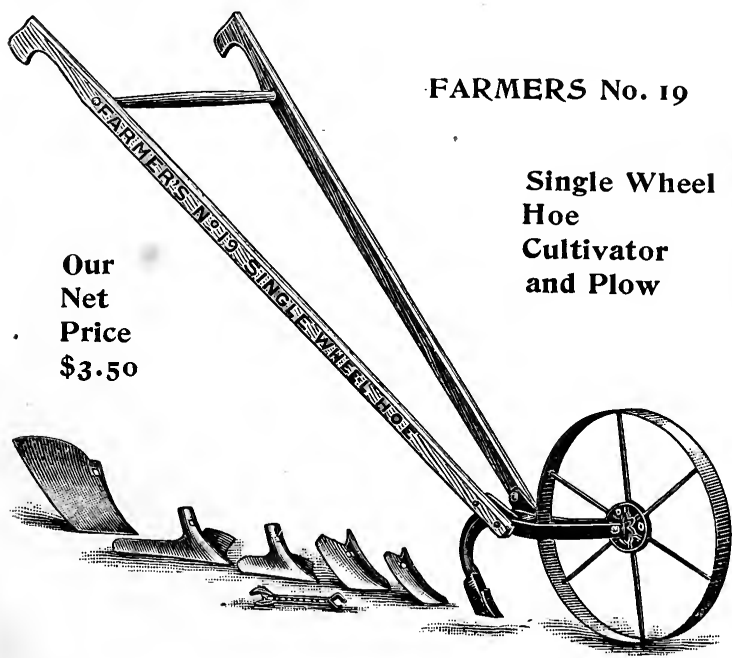

\section{Hill and Drill Seeders}

1No. 6. (New.) Fill and Drill Seeder and Single Wheel Hoe Net price..........\$13 00 No. 6. Fill and Drill Seeder, without cultivating attachments ............................... o. 25. Combined Iill and Drill seeder, with 8 weeding and cultivating tools; hopper holds $21 / 2$ quarts. Net price.................... 1300 No. 4. Combined Fill and Drili Seeder, with tools for cultivating; hopper holds 3 pints. Without rakes. Net price................ 10 80 No. 4. As above, with rakes................. 1150 No. 4. As a Seeder only, without tools....... 850 No. 3. Fill and Drill Seeder, without cuitivating tools; hopper holds 3 quarts ro. 5. Fill and Drill Seeder. Larger size than No. 3, and especially made for market gardeners; hopper holds 5 quarts. Price...... 1250

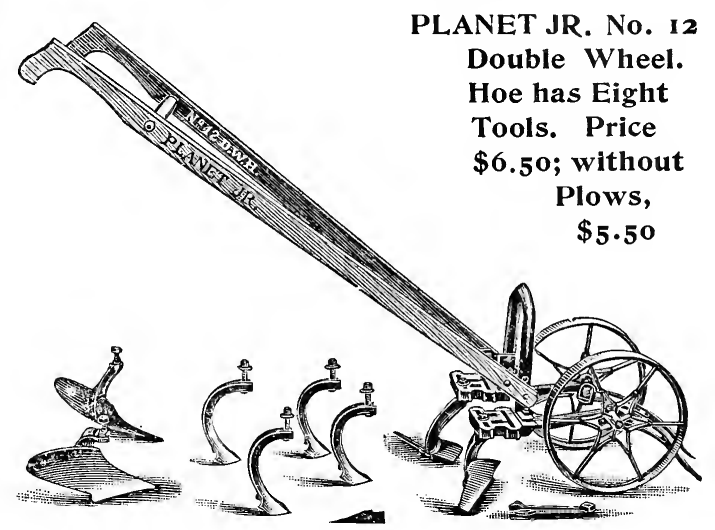

Planet Jr. Horse Tools

No. 10. Horse Hoe Cultivator, Hiller, and Vine Turner. With four cultivator teeth, one sweep and vine turner, without lever wheel, a fine implement for working tobacco or any crop close up, moving leaves to one side crop close up, moving leaves to one side
without injury; very heavy construction.
Price $\ldots \ldots \ldots \ldots \ldots \ldots \ldots \ldots \ldots \ldots \ldots \ldots \ldots \ldots \ldots \ldots \ldots \ldots \ldots \ldots$

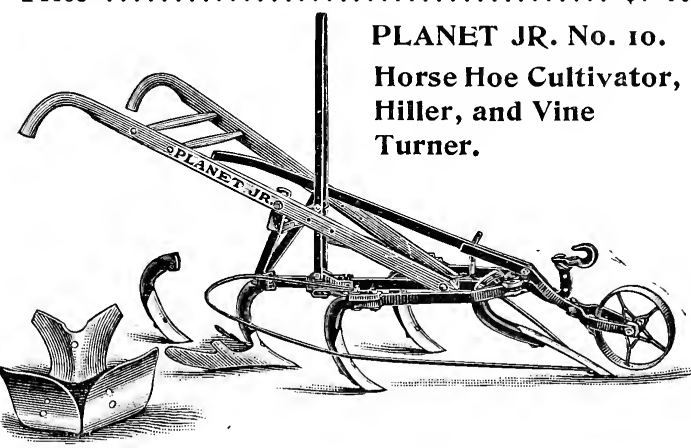

No. 9. Horse Foe and Cultivator, with all attachments complete. Price, with wheel... 725 Without wheel. Price............... 650 No. 9. Plain Cultivator, expanding lever, five teeth fitted with $1 \frac{1 / 4}{4}$ inch steels. Without

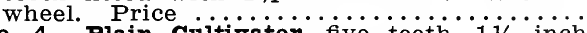
xo. 4. Plain cuitivator, five teeth, $11 \%$ inch steels, without wheel. Price............ 12 Tooth Harrow, with expanding lever, pul2 verizer, and wheel, complete. Price....... 12 Tooth Farrow, with wheel, without pulver2 Tooth Frarrow, without pulverizer or wheel.

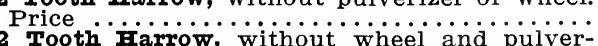
12 Tooth تarrow, without wheel and pulverizer, and with No. 12 expander. Price. vator. Pivot axle; fitted with six 21/4 inch vator. Pivot axle, fitted with six $21 / 4$ inch steels, two 8 -inch shovels, and two sets of 3000 


\section{CONTENTS OF CATALOGUE.}

\begin{tabular}{|c|c|c|}
\hline 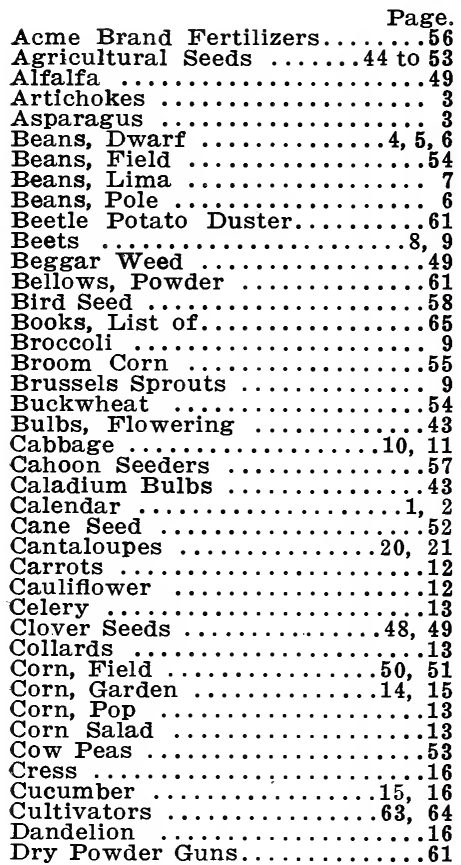 & 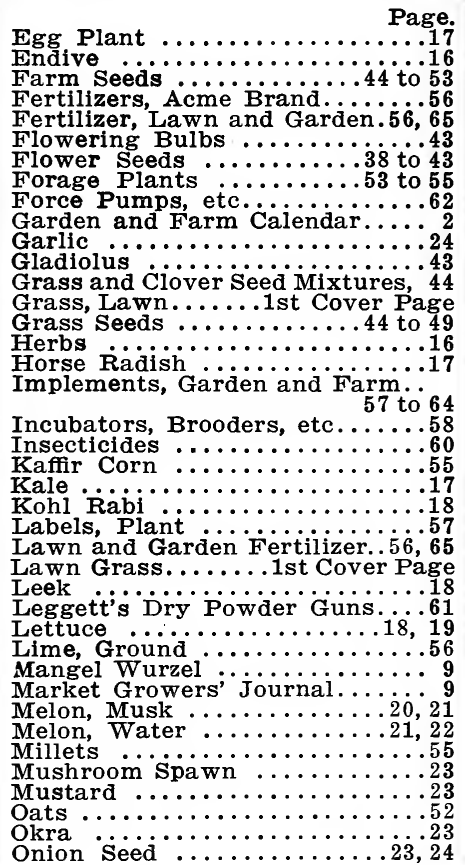 & 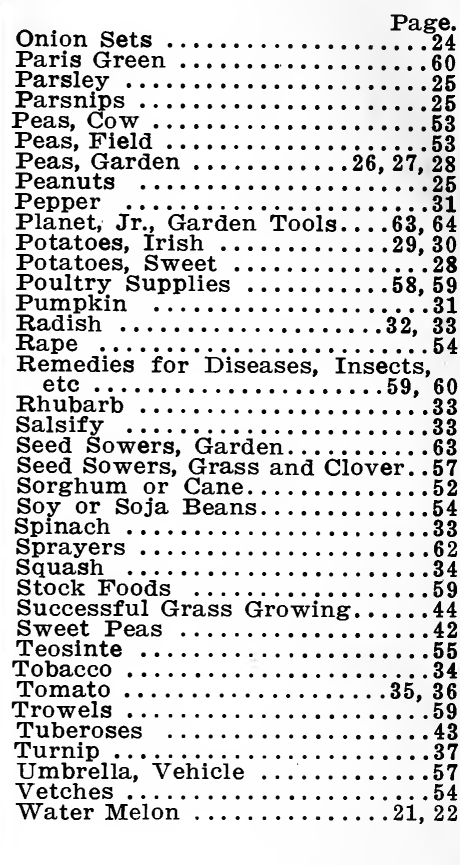 \\
\hline
\end{tabular}

\section{Planet Jr. Pivot Wheel Riding Cultivator}

Can be used as a Plow, Furrower, Ridger, Marker, Hiller and for Fallow Work.

An indispensable tool adapted to nearly all horse work on the farm or garden. We have sold a large quantity of them during the past four seasons and wherever used is acknowledged the most useful tool of its kind known. It is so simple in operation and so well under control of the operator that a 10-yearold boy can do as good work with it as an experienced man.

In this section it is in general use by gardeners in the cultivation of potatoes, both sides of the row at once, from planting to last working. It is the finest corn cultivator in use and the most practical useful tool for all cultivating work for the garden, farm, or orchard. For tobacco nothing can excel it and the most prominent planters are using and endorsing it enthusiastically. As shown in the cut the equipment consists of eight cultivator teeth generally used four on a side and an extra ninth tool for fallow work; it also has four reversible plows, two medium and two large, and two eight-inch furrowing shovels, all easily applied and adjusted. It can be easily adjusted to any width rows.

We have not space to fully describe this fine implement. Iet us send you fuller information. To see it work you will want it. If you buy it you would not sell it for twice the price if you could not get another. We sold last season over one hundred of these cultivators in this county alone, and wherever these are used in a neighborhood every other grower with much cultivation to do antee this implement thoroughly to do satisfactory work.

These cultivators are cheaper at the price, considering the material, attachments, and finish, than any other cultivators made.

\section{AII OF THE ABOVT CUITIVATORS CAN BE SUPPIIED WITH SPRING TRIP TFETH INSTFAD} OF TEETH AS SHOWN IN CUT AT \$5.00 EXTRA PRICE.

We carry in stock Davis' Swing Churns, Butter Paper, and other Dairy Supplies; also various kinds of Farrows, Cultivators, Plows, Corn Planters, Grain Drills, Potato Planters, Feed Cutters, Rollers, Hor Mowers, Iawn Mowers, and Iawn zollers. Catalogues and prices cheerfully furnished on application. 
THE PACKETS OF

Blue Ribbon

Seeds

Are large and well filled. Prices on

Packets, Ounces, and $\frac{1}{4}$-lbs. include Postage

Prices on Packets of Blue Ribbon

Flower Seeds

For $\$ 0.35$ sent select $\$ 0.50$ worth For .50 sentselect .75 worth For 1.00 sent select 1.75 worth For 2.50 sent select 5.00 worth

Postage paid by us.
ORDER FOR

Blue Ribbon Seeds

EROM

WOOD, STUBBS Q CO.

Incorporated

Seed Growers and Importers

219-221 E. Jefferson St., LOUISVILLE, KY.
Prices in Bulk of

Blue Ribbon

Vegetable, Field, and

Flower Seeds

Are Net, and as they are made very low no dis

count can be allowed.

Postage on Bulk Seed

1 lb. 8 cts.; 1 pint, 8 cts. 1 quart, 15 cts.

Our Calendar

(See description, page 1.) Mailed FREE with each order of 50c. when requested.
Please forward the following as per terms of your 1909 Descriptive Catalogue to

Date (Ifladies, state whether)
Miss or Mrs.

Your Name

Post-Office

R. F. D.

Shipping Depot

County

State

Send the Order by

(State here whether to send by Mail, Express, or Freight, and route to ship by, if any special route is wanted.)

\section{Amount Enclosed}

P.-O. Money Order

Check or Draft

Cash

Stamps

REnITTANCES are always safe when sent by Registered Leter, PostaOffice Money Order, Express Money Order, or Bank Draft, Small amounts can be sent in postage stamps, folding same in brown wrapping paper to prevent sticking.

SEEDS AND BULBS BY EXPRESS. From Louisville to all points at a rate of twenty per cent less than usual rates. Freight rates are very low owing to our central location.

A ONE DOLLAR ORDER in Garden or Flower Seeds entitles you to a 10 weeks' subscription FREE to the Weekly Market Growers' Journal. A \$5.00 order for Garden and Flower Seeds entitles you to a one year's subscription FREE. Mention this in ordering. See page 9. 
A ONE DOLLAR ORDER in Garden or Flower Seeds entitles you to a 10 weeks' subscription FHEE to the Weekly Market Growers' Journal. A $\$ 5.00$ order for Garden and flower Seeds entitles you to a one year's subscription FPEE. Mention this in ordering. See page 9.

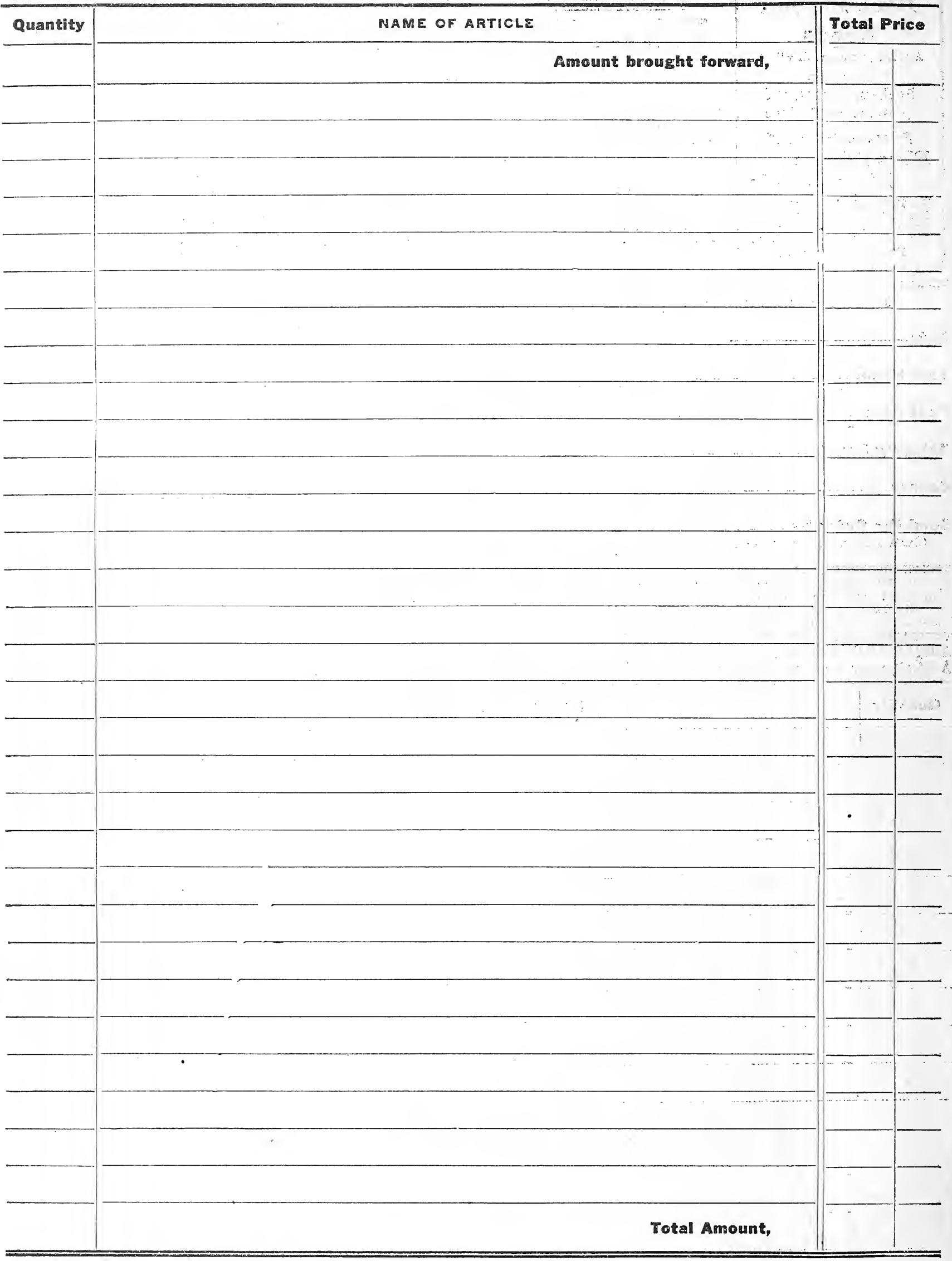

Look over the following list. We would appreciate orders for these articles, as our stocks are the very best, and prices as low or lower than usually offered: Fertilizers, Implements, Farm and Carden Hand Tools, sprayers and Powder Guns, lnsecticides, Stock Foods, sheet from this order. Kindly send us the names and addresses of any friends of neighbors likely to purchase seeds, so that we can mail them our Catalogue. 
ORDER FOR BLUE RIBBON SEEDS.

\section{WOOD, STUBBS \& CO.,}

IXCORPORATED.

\section{Seedsmen,}

\section{From}

Nos. 229-231 E. Jefferson St.,

P. 0.

State

LOUISVILLE, KY. 


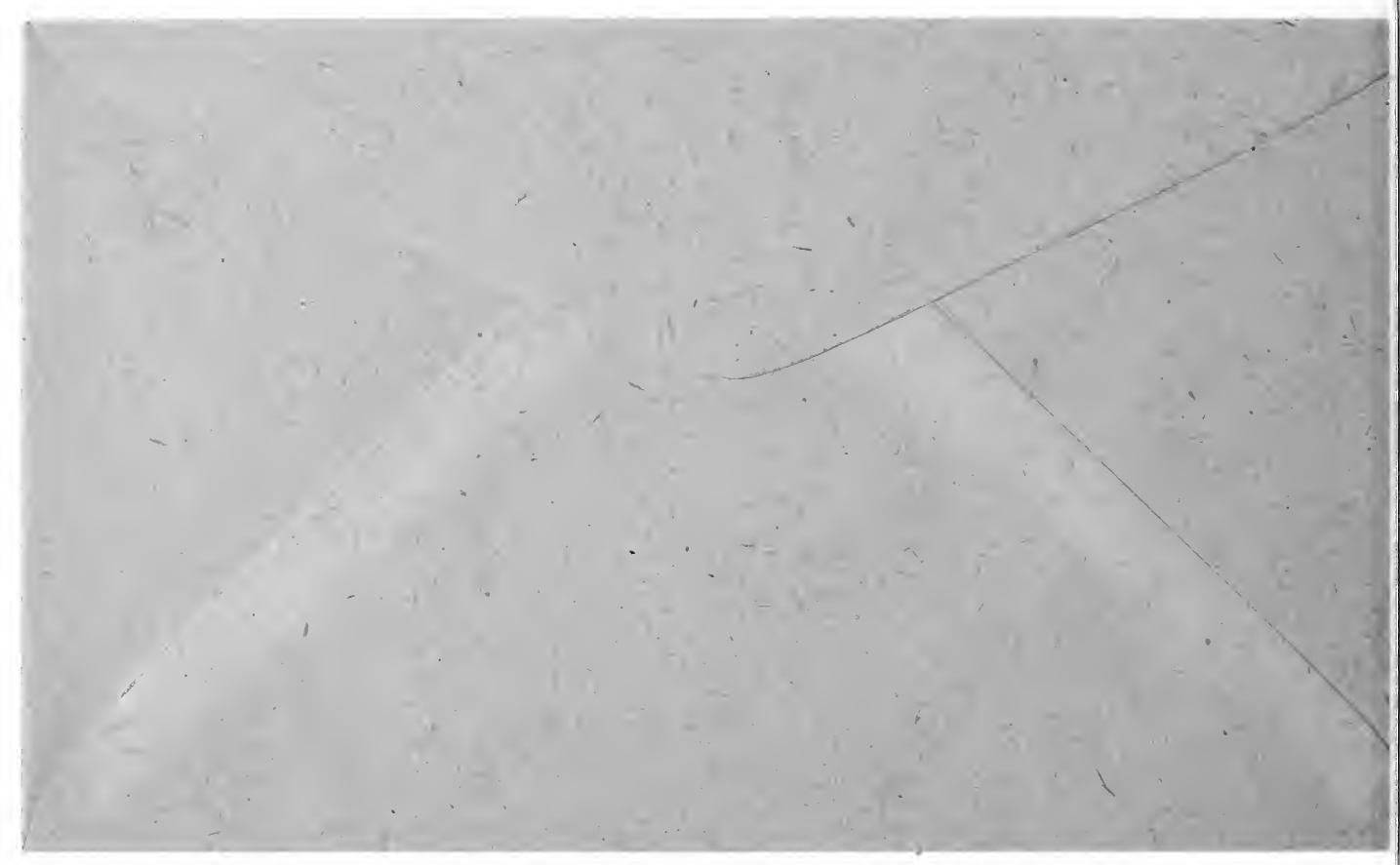




\section{Wood,Stubbs \& Co.'s Lawn and Garden Fertilizer}

A complete and concentrated manure for making and sustaining fine lawns. It will improve the grass wonderfully, giving it a beautiful grcen color. For new lawns apply broadcast five pounds to 300 square feet (12 $\times 25)$ or 600 pounds per acre, working in and mixing in the soil. As a top dressing in the winter or early spring, apply at the rate of five pounds for 500 square feet, or 400 pounds per acre. The best time to apply as a top dressing is before a rain or snow. For Garden crops and Flowers it can be used either in hills or drills, but broadcast is better, applying at the rate stated above and working into the soil immediately before the crop is planted. Price, 5 lbs. 30c.; 10lbs. 50c.; $25 \mathrm{lbs}$. $\$ 1.00 ; 50$ lbs. $\$ 1 . .5 ; 100$ lbs. $\$ 3.00 ; 200$ lbs. $\$ 5.00 ;$ ton, $\$ 45.00$

\section{Books for Farmers, Stockmen, Gardeners,}

\section{and on Subjects pertaining to Agriculture, etc.}

A Complete Catalogue of Books of Interest to Farmers and Agriculturists will be mailed on application. Prices given below include postage.

\section{GENERAL FARM BOOKS.}

Agriculture, Manual of .......... Emerson and Flint_- $\$ 1.00$ Chemistry of the Farm ............R. Warrington -...- 1.00 Draining for Profit and Health..Geo. E. Warring, Jr. - - 1.00 Elements of Agriculture..........L. H. Bailey -.....-. 1.25 Farm Book, American........... R. L. and L. F. Allen -.....-..-.-2.00

Farmer's Cyclopedia of Agricul-

ture (450 pages, comprising all subjects.)

Farm Grasses of the U. S. ....... W. J. Spillman .....- 1.00

Farmers Business Handbook.... Roberts ............- 1.32

Fertilizers …................ B. Boorheis -...- 1.38

Forage Crops, Other than Grzsses Thomas Shaw --.-- 1.00

Fertility of the Land, The ......... I. P. Roberts -...-_ 1.25

Grasses and Forage Plas.ts ...... Flint -..._......- 2.00

Grasses and How to Grow Them Thomas Shaw -..--- 1.50

How the Farm Pays................Crozier \& Henderson

Practical Farming................ W. F. Massie -... 1.50

Principles of Agriculture.........L. H. Bailey -..--.- 1.60

Soils, The ........................ H. King -..... 1.63

Soiling Crops and the Silo . ....... Thomas Shaw ...... 1.50

Silos, Ensilage and Silage........Manly Miles .....-.-. 50

Soils and Crops of the Farm.... G. T. Horrow \& T.

F. Hunt -

Ten Acres Enough................. P. Roberts -.-.-.- 1.00

\section{BOOKS ON GARDENING, ETC.}

Forcing Book, The .............. L. II. Bailey -....- 1.00 Garden Making................. L. II. Bailey _...... 1.00

Gardening for Pleasure -.......... Henderson -.--.-.-.- 1.50

Gardening for Profit (Enlarged). Peter Henderson -..- 1.50

Greenhouse Management ........ L. R. Taft -.-.-- 1.50

Home Floriculture ............. E. E. Rexford …- 1.00

Horticulturist's Rule Book ....... L. H. Bailey -...... .75

Insects Injurious to Vegetables_. F. H. Chittenden -.. 1.50

Market Gardening ................. Landreth -.......-. 1.00

Plant Diseases.................... Geo. Massee - -...-. 1.60

Practical Garden Book ............ L. II. Bailey -.-.--- 1.00

Prize Gardening . ............... G. Burnap Fiske -.. 1.00

Southern Gardeners' Practical

Manual ....................... J. S. Newman ....... 1.00

Sprasing of Plants .............. E. G. Lodeman ....-. 1.00

Vegetable Gardening ............ S. B. Green -...-.- 1.00

Vegetable Growing in the South

for Northern Markets .......... Prof. P. H. Rolfe ..- 1.00

\section{HORSE AND STOCK BOOKS.}

American Cattle Doctor .......... Geo. H. Dadd

Animal Breeding . ............... Thomas Shaw ..... 1.50

Dairyman's Manual .............. Henry Stewart ..... 1.50

Harris on the Pig ................... Joseph Harris ....-- 1.00
The Horse, How to Buy and Sell. Peter Howden Shepherd's Manual ................ Henry Stewart ...... 1.00

Swine Husbandry ................. F. D. Coburn ...... 1.50

Diseases of Swine .............. Dr. R. A. Craig _... $\quad .75$

Successful Dairying .............. II. C. Carpenter

(paper) -

Profitable Dairying........... C. L. Peck .....

\section{FRUIT AND NUT GROWING.}

Fruit Harvesting, Storing and

Marketing ....................... . . Waugh …. 1.00

Grape Culturist .................. A. S. Fuller -..... 1.50

Grape Growing and Wine Making Prof. Geo. Husmann 1.50

Nut Culturist ................... A. S. Fuller -...-. 1.50

Principles of Fruit Growing ...... L. H. Bailey -......- 1.25

Small Fruit Culturist ............... A. S. Fuller _...... 1.00

Strawberry Culturist .............. A. S. Fuller ........ .25

Successful Fruit Culture .......... S. T. Maynard ...-. 1.00

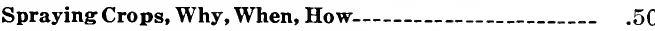

\section{SPECIAL CULTURE BOOKS.}

Alfalfa ..... .

The Book of Alfalfa (a larger edi-

tion than above) .............. F. D. Coburn _... 2.00

Clovers and How to Grow Them.. Thos. Shaw --.-- 1.00

Asparagus ....................... M. Hexamer -.. .50

Bean Culture ...................G. C. Levey _....-. $\quad .50$

Broom Corn and Brooms ................. $\quad .50$

Cabbage, Cauliflower, etc......... C. L. Allen -...... .50

Celery Culture .................. W. R. Beattie -.... $\quad .50$

Manual of Corn Judging .......... A. D. Shamel -.... $\quad .50$

Ginseng ......................... Maurice G. Kains -. $\quad .50$

Hemp ........................ S. S. Boyce -... $\quad .50$

Mushrooms, How to Grow Them. Wm. Falconer -...- 1.00

New Onion Culture ............... Greiner -........ $\quad .50$

Potato, The.................... Samuel Fraser -...- .75

New Rhubarb Culture .......... J. E. Morse -

Sweet Potato Culture ............ Jas. Fitz -

Tobacco Culture ................. (paper) -........... $\quad .25$

Tomato Culture ................ W. W. Tracy ... 50

\section{POULTRY AND MISCELLANEOUS BOOKS.}

Capons for Profit ................. T. Greiner …...... . .50 Profits in Poultry .................... 1.00

New Egg Farm ................... H. H. Stoddard ..... 1.00 Turkeys and How to Grow Them. Herbert Myrick -..-- 1.00 Quinby's New Bee Keeping ...... L. C. Root .......-. 1.00 Landscape Gardening ............. F. A. Waugh ....... $\quad .50$ Beautifying Country Homes..... Weidenmann ........ 10.00 Practical Forestry ................ A. S. Fuller -.......- 1.50 Weeds and How to Eradicate

Them ..................... Thos. Shaw -..... .50

Barn Plans and Outbuildings........ 1.00

Homes and Homebuilders . . . . . . . .

OUR FALL CATALOGUE of Grass Seeds, Clovers, Seed Wheat, Seed Grain, Vegetable and Flower Seeds, Flowering Bulbs and Sundries for Fall use ready in August.

Send Us Your Name Now. Also include some of your neighbors who buy seeds. 


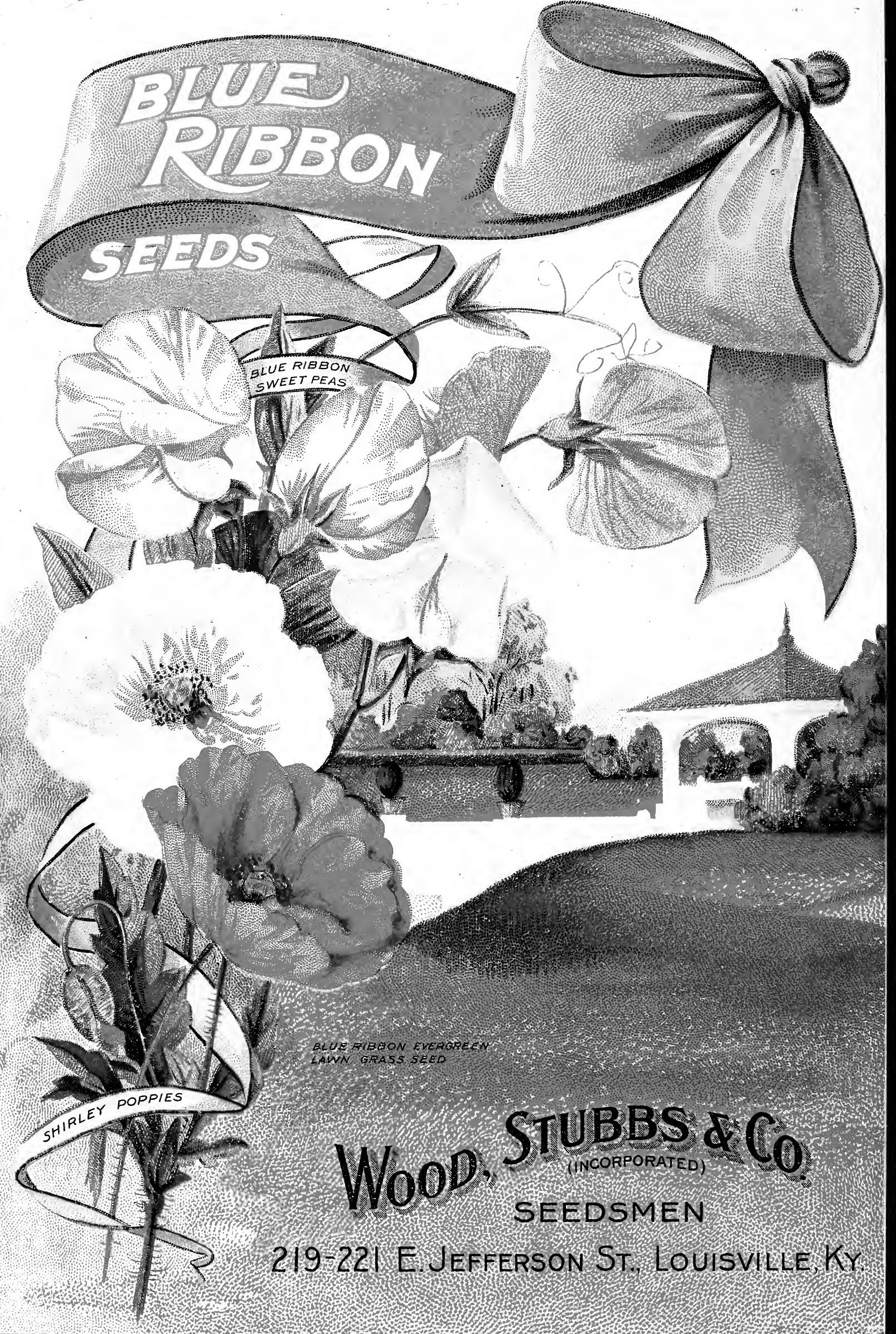

